\title{
A History of Scottish Economic Thought
}

Modern economics has at its foundation scholarly contributions from many prominent Scottish thinkers. A History of Scottish Economic Thought examines the roots of this great tradition, places in perspective a selection of authors and assesses their contribution over three centuries in the light of a distinctive Scottish approach to economics. Scottish Enlightenment thought more widely is an established area of research interest. This volume offers new scholarship on key Enlightenment figures; but the emphasis is on the approach to economic thought which developed in that period and continued through to the twentieth century.

Smith and Hume may be key figures, but other less familiar authors are also of substantial interest as economic thinkers, and include a murderer, a revolutionary, a medical practitioner and a novelist (John Law, Sir James Steuart, John Rae and Shield Nicholson, respectively). Also included in the volume are discussions of Francis Hutcheson, James Mill, J. R. McCulloch, Thomas Chalmers and William Smart.

The nature of the advances made in this historical development is also highly relevant to modern methodological discussion in economics. The Scottish approach identifies principles of human nature from detailed observation and historical study, but as these principles are manifested in different ways in different contexts there is little scope for laws of economic behaviour. The principles, together with a combination of inductive and deductive methods, help us to derive theory suited to particular contexts, with attention paid to the historical, political, social and moral aspects of each context.

Alexander Dow is Professor of the Scottish Economy in Glasgow Caledonian University, UK. Sheila Dow is Professor of Economics at the University of Stirling, UK. 
Routledge history of economic thought

Edited by Mark Blaug

Co-Director Erasmus Center for History in Management and Economics, Erasmus University, the Netherlands

A History of Japanese Economic Thought

Tessa Morris Suzuki

A History of Australian Economic Thought

Peter Groenewegen

A History of Indian Economic Thought

Ajit K. Dasgupta

A History of Canadian Economic Thought Robin Neill

A History of Swedish Economic Thought Bo Sandelin

A History of Portuguese Economic Thought Jose Luis Cardoso and Antonio Almodovar

A History of Latin American Economic Thought

Oreste Popescu

A History of Norwegian Economic Thought

Olov Bjerkholt and Pal Lykkja

A History of Russian Economic Thought

Vincent Barnett

A History of Scottish Economic Thought

Edited by Alexander Dow and Sheila Dow 


\section{A History of Scottish Economic Thought}

Edited by Alexander Dow and Sheila Dow

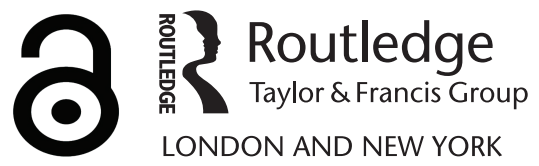


First published 2006

by Routledge

2 Park Square, Milton Park, Abingdon, Oxon OX14 4RN

711 Third Avenue, New York, NY 10017, USA

Routledge is an imprint of the Taylor $\mathcal{E}$ Francis Group, an informa business (C) 2006 editorial matters and selection, Alexander Dow and Sheila Dow; individual chapters, the contributors

Typeset in Baskerville by Wearset Ltd, Boldon, Tyne and Wear

The Open Access version of this book, available at www.taylorfrancis.com, has been made available under a Creative Commons Attribution-Non Commercial-No Derivatives 4.0 license.

British Library Cataloguing in Publication Data

A catalogue record for this book is available from the British Library

Library of Congress Cataloging in Publication Data

A catalog record for this book has been requested

ISBN13: 978-0-415-34437-1 (hbk) 


\section{Contents}

List of contributors vii

Acknowledgements $\quad x$

1 Introduction 1

ALEXANDER DOW AND SHEILA DOW

2 John Law and the Scottish Enlightenment 9

ANTOIN E. MURPHY

3 Francis Hutcheson, 1694-1746 27

ANDREW S. SKINNER

4 David Hume as a political economist 46

CARL WENNERLIND

5 Sir James Steuart, Principles of Political Oeconomy 71

ANDREW S. SKINNER

6 Adam Smith: real Newtonian 102

LEONIDAS MONTES

7 Adam Smith: common sense and aesthetics in the age of experiments

FLAVIO COMIM

8 James Mill as economist: theory dominated by deductive method

THOMAS S. TORRANCE

9 John Ramsay McGulloch

D. P. O'BRIEN 
vi Contents

10 The place of Thomas Chalmers in Scottish political economy

A. M. C. WATERMAN

11 John Rae

DOUGLAS MAIR

12 Economics in the Scottish universities from the late nineteenth century

ALEXANDER DOW AND ALAN HUTTON

13 A Scottish tradition of applied economics in the twentieth century

ALAN HUTTON

14 Postscript

SHEILA DOW

Index

254 


\section{Contributors}

Flavio Comim holds various positions in St Edmund's College, Cambridge, and UFRGS, Brazil. He received his PhD from the University of Cambridge in 1999, with the thesis 'Commonsense Economics: essays on the role of common sense in the history of economic thought'. His areas of research comprise the history of economic thought, development ethics and development economics, with emphasis on poverty and environment issues. He has published papers in HOPE, Review of Political Economy, Structural Change and Economic Dynamics and Review of Social Economy.

Alexander Dow is Professor of the Scottish Economy in Glasgow Caledonian University, having served as Head of the Department of Economics during 1989-99. He taught previously at the Universities of Manitoba, Toronto and Stirling, after working for several years with the Commonwealth Secretariat. He studied History and Political Economy at the University of St Andrews, and Economics at Simon Fraser University and the University of Manitoba. Areas of research interest and publications over the years have included the economic history of Canada, British economic performance and Scottish political economy.

Sheila Dow is Professor of Economics at the University of Stirling, where she has taught since 1979, following previous employment by the Bank of England and the Government of Manitoba. She has a long-standing interest in the Scottish political economy tradition, with a particular focus on Hume and Smith, as part of a wider interest in the methodology of economics. Her other interests include the theory of money and banking. Her latest book is Economic Methodology: An Inquiry (2002).

Alan Hutton, Senior Lecturer in Economics at Glasgow Caledonian University, is a political economist who writes and teaches in and about the Scottish political economy tradition. Recent publications address issues in energy utility regulation in Scotland and the ideological significance of mainstream economics, as well as the history of economics in Scotland. 
Douglas Mair is Professor Emeritus at Heriot-Watt University. He has a long-standing interest in the history of economic thought, particularly Scottish political economy. He edited The Scottish Contribution to Modern Economic Thought (1990) and co-edited The Economics of John Rae (1998). He has a particular interest in John Rae, on whom he has published papers in the Scottish Journal of Political Economy (1990) and the Journal of the History of Economic Thought (2001).

Leonidas Montes is Associate Professor of Economics at Universidad Adolfo Ibáñez, Santiago, Chile. After studying Engineering, Philosophy and Political Science as an undergraduate in Chile, he obtained his MPhil, and in 2002 his PhD, in Economics at King's College, University of Cambridge. His PhD dissertation has been published as Adam Smith in Context: A Critical Reassessment of some Central Components of his Thought (2004).

Antoin E. Murphy is an Associate Professor of Economics in Trinity College, University of Dublin. His special interests are in macroeconomics, monetary economics and the history of economic thought. He is one of the joint managing editors of the European Journal of the History of Economic Thought. His books include Richard Cantillon: Entrepreneur and Economist (1986), John Law's Essay on a Land Bank (1994), Monetary Theory 1601-1758 (ed., 1997), John Law: Economic Theorist and Policymaker (1997) and Du Tot: histoire du système de John Law 1716-1720 (ed., 2000).

D. P. O'Brien is Emeritus Professor of Economics, University of Durham. He was Professor of Economics at Durham 1972-97, and was at Queen's University, Belfast 1963-72. It was at Queen's that his interest in McCulloch began, under the guidance of Professor R. D. C. Black. His work in the history of economic thought, which covers writers from Bodin to Hayek and Robbins, includes J. R. McCulloch (1970), The Correspondence of Lord Overstone (3 vols, 1971), Thomas Joplin and Classical Macroeconomics (1993) and The Classical Economists Revisited (2004).

Andrew S. Skinner continues to teach part-time at Glasgow University, where he has taught since 1964 (following posts at Queen's University Belfast and Queen's College Dundee, and an influential period of study at Cornell University). Professor Skinner has published a number of articles on eighteenth-century subjects. He has edited James Steuart's Principles (1966, 1998) and Smith's Wealth of Nations, both in Penguin books; and, with R. H. Campbell and W. B. Todd, the Glasgow edition of Smith's Works and Correspondence. He is the author of A System of Social Science: Papers Relating to Adam Smith (1979, 1996).

Thomas S. Torrance is a Senior Lecturer in Economics at the School of Management and Languages of Heriot-Watt University, Edinburgh. He 
has an MA degree from the University of St Andrews and a PhD from the University of Edinburgh. Previously he held a teaching position at the Department of Economics at the University of Aberdeen. His research interests and publications are in the two different areas of open-economy macroeconomics and the methodology and history of economic thought.

A. M. C. Waterman is a Fellow of St John's College, Winnipeg, and Professor of Economics in the University of Manitoba, where he teaches history of economic thought and works on various aspects of the relation between Christian theology and economic theory. His Revolution, Economics and Religion: Christian Political Economy 1798-1833 (1991) was awarded the Forkosch prize for intellectual history in 1992. His latest book is Political Economy and Christian Theology since the Enlightenment (2004).

Carl Wennerlind is an Assistant Professor of History at Barnard College. $\mathrm{He}$ is co-editor of the forthcoming Essays on David Hume's Political Economy (2006) with Margaret Schabas. His articles on Hume's political economy have also appeared in History of Political Economy, Hume Studies and Journal of Political Economy. 


\section{Acknowledgements}

We would like to express our grateful appreciation to our contributors for their essential role in the making of this volume, and the scholarly way in which they engaged with the project. We are particularly grateful to Andrew Skinner, not only because he contributed two chapters, but also because it was he who suggested the project to us in the first place, and who provided helpful advice and support throughout. Finally we are grateful to Robert Langham of Routledge for his friendly support (and patience) throughout the project.

This book is dedicated to Christine and Anna. 


\title{
1 Introduction
}

\author{
Alexander Dow and Sheila Dow
}

The prospect of putting together an edited volume on the history of Scottish economic thought was both exciting and daunting: exciting because there is such a wealth of scholarship on many of the key Scottish figures in the early development of what was to become modern economics; but daunting for the same reason. It was decided early on, therefore, that it was an impossible task to provide a comprehensive coverage of thinking, past and present, on the full range of figures in the history of Scottish economic thought, appealing though that might be. Rather the approach we have taken is highly selective. But in the process we hope to have provided a flavour of a range of thinking on some of the central figures, their contexts and the implications of their work.

This selection in turn inevitably reflects a particular view of Scottish economic thought, although we should emphasise at the start that contributing authors do not necessarily share this view. (While asked to bear it in mind as a point of reference, authors were explicitly invited to present their own views.) Our view of Scottish economic thought is one which fits naturally in a book series aimed at representing economic thought in terms of national identity. Rather than seeing national identity as simply providing a convenient way of segmenting the full corpus of economic thought, we see it as material to the content of national economic thought. Our own view, therefore, is that there has been a tradition in Scottish political economy which stems from the sixteenth and seventeenth centuries, reached its fullest flower in the Enlightenment period of the late eighteenth and early nineteenth centuries, and whose echoes continue to this day (see also Mair 1990).

The selection of individual subjects reflects this approach in that we have attempted to give a flavour of Scottish economic thought - and more particularly of the Scottish approach to economics - from the early Enlightenment up to the twentieth century. Thus we have focused on only five key eighteenth-century figures: in chronological order, Law, Hutcheson, Hume, Steuart and Smith. Nineteenth-century thought is then addressed by chapters on (James) Mill, McCulloch, Chalmers and Rae. The perpetuation of the tradition through the institutional arrangements 
for economics education and policy making in Scotland from the late nineteenth century on are then set out, with a focus on the work of key figures, including Smart, Nicholson, Scott and Cairncross. Indeed, it was Scott who first coined the term 'Scottish Enlightenment' in his 1900 biography of Frances Hutcheson. A similar need to trace the history of Scottish philosophy beyond the Enlightenment period has been expressed by Broadie, who suggests that nineteenth-century Scottish philosophy 'has hardly been documented' (Broadie 2003: 6). In philosophy too the Enlightenment period has been the primary focus of attention.

\section{The Scottish political economy tradition}

The identification of such a tradition stems from understanding Scottish economic thought in terms of the wider context in which it was developed and expressed. In particular, the tradition is rooted in the Scottish philosophical tradition, as well as in the institutional arrangements of education and government. This factor was one of the influences in our choice of topics and authors, since it was judged to be important to flesh out the historical, institutional and philosophical background to the development of economic thought. Further, the selection reflects the view that the Scottish tradition not only had origins in pre-Enlightenment thinking, but also extended well beyond the Enlightenment period, into the twentieth century.

Before introducing the individual chapters, we set out very briefly the argument that it is reasonable to think in terms of a Scottish political economy tradition (see further Dow 1987; Dow et al. 1997, 1998a, 1998b, 2000, 2003). Let us start with the historiographical background. In common with the bulk of scholarship in this area, we see the purpose of the history of economic thought as being to uncover as far as possible the meaning of authors. While the outcome may well inform modern economic debate, the aim is to impose modern concepts and understandings on the texts as little as possible. This requires attention to the context in which these authors wrote, where that context is understood to encompass the full range of political, cultural, social, religious and philosophical factors. Further, in line with Quentin Skinner's $(1969,1988)$ approach, it requires attention to divining the intentions of the author in writing the text within that context. The environment of a national group of writers has some continuities over time, particularly when considering the philosophical context and institutional structure of the nation. (Even discontinuities take some of their meaning from the past.) So we would in fact expect to find some commonalities in the economic thought of writers within any one nation.

By 'tradition' we mean something of longer standing than, say, a school of thought, and something broader than, say, a set of theories and policy prescriptions. Not only have economic theory and policy changed, in Scot- 
land, as elsewhere, over the years, but also there have been fierce debates among contemporaries within different periods, including in Scotland in the Enlightenment period. Further, widely divergent sets of ideas have been traced back to Scottish thought, with both Marx and Hayek, for example, identifying intellectual roots in Smith.

The continuity captured in the tradition refers rather to the approach taken by Scottish economists to their subject. This was profoundly influenced by Scottish philosophy, and the fact that philosophy was core to the university curriculum; indeed, some form of philosophical training was compulsory in the Scottish universities up to the 1960s. The distinctive evolution of Scottish philosophy, and its application to current affairs, was most evident in the Enlightenment period, when it was in turn influenced by the particular political and economic circumstances of the time. These circumstances included the shift of political power to London, the social upheaval caused by population movements following the Jacobite rebellions of 1715 and 1745, and more generally with migration from the country into the towns, the practical problems posed by the development and application of new inventions, and the building up of international trade, investment and migration.

Scottish philosophy drew heavily on ideas developed elsewhere; this is particularly true of Hume and Smith, whose Continental travels exposed them to current thinking elsewhere. Nevertheless it is with the French Enlightenment that we see the greatest contrast to the Scottish Enlightenment. In Scotland (most explicitly in the case of Hume) there was a turning away from rationalism towards modesty as to the scope for establishing certain knowledge. By embracing the understanding of rationalism as a dead end, the Scots philosophers turned instead to building a science of human nature as the foundation for all other scientific knowledge. Reason would come only after belief, sentiment and experience. This was a philosophy which suited the needs of a small nation eager to grapple with its practical problems and to find a place in the world.

We characterise the Scottish approach as having the following features:

1 An acceptance of the limitations of theory.

2 Recognition of the sociological and psychological aspects of theory appraisal.

3 Concern with practical issues.

4 A consequent preference for breadth of understanding of the background to these issues, over depth of isolated aspects, based on direct observation.

5 A preference for drawing on several disciplines in an integrated manner to provide that depth.

6 The derivation of (provisional, contestable) principles from experience. 
7 The specification of first principles in terms of a non-individualistic representation of human nature, with a consequent emphasis on conventional behaviour.

8 A preference for approaching a subject's first principles by discussing its contextual development.

9 A preference for theoretical argument expressed in terms of first principles.

As with all such categorisations, this tradition which we have identified took on different characteristics for different key figures. Further it cannot be universally applied. We have in this volume the example of James Mill, who was educated in Scotland but who nevertheless turned his back on the tradition. Similarly we have the example of Nicholson, who came only later in life to the Scottish tradition yet embraced it wholeheartedly. As time has passed, further, the tradition can be seen to have weakened. But, for those of us brought up in the Scottish tradition, it is clearly recognisable still. There would seem to have been enough continuity in the Scottish philosophical, social, political and educational environment to allow the tradition to persist.

\section{An introduction to the chapters}

The chapters are arranged roughly in chronological order, in terms of the timing of the main contributions of the individuals concerned, or the sets of ideas under consideration where a chapter is not confined to one individual. The first set of six chapters is concerned with the eighteenth century. The figure of Adam Smith looms large, either as the primary subject (as in Chapters 6 and 7), or as a point of reference (in Chapters 2 to 5$)$.

The first figure, presented in Chapter 2 by Antoin Murphy, is one who has tended to be neglected in accounts of eighteenth-century Scottish thought: John Law. Right at the start therefore we have an important example of disputes among Scottish figures over economic theory and policy, since one of the reasons for the neglect of Law must surely be Hume and Smith's dismissal of him as being unworthy of attention, although they were at times equivocal on his ideas on money. In response to the need to address unemployment, Law had developed a nonneutrality theory of money, and saw the expansion of money through bank credit as the solution. Law exemplifies the practical orientation of Scottish Enlightenment thought in that he proceeded to set up a bank on these principles in France, as well as a company designed to manage the national debt and to promote trade. Both enterprises failed. We will see the evolution of Scottish thought with respect to the meaning and role of money continuing as a thread through the next four chapters. It is not surprising that this should be important for Scottish thinkers at a time 
when Scottish banking was evolving so rapidly, and in many ways taking a lead in banking practice.

While Smith distanced himself from Law, he acknowledged a great debt to his teacher, Francis Hutcheson, who is the subject of the third chapter. Andrew Skinner demonstrates the origins of much of Smith's thought in Hutcheson's writing, and in turn demonstrates Hutcheson's debt to Pufendorf. Hutcheson's moral philosophy provided the foundations for a theory of human nature such that the capacity for moral judgement was a precondition for economic activity. In this, he addressed the question of how a self-regarding individual could be fitted for the social state, another theme which will be evident as we continue our consideration of eighteenth-century Scottish thought. The faculty of sentiment, and thus of sympathy, linked the individual and social levels of economic activity, a link which was central to Hutcheson's early statements of the theories of the division of labour and of value, on which Smith was to build. In the meantime, Hutcheson's focus both on individual liberty and the need for a social contract were to extend his influence to the early political development of the American colonies.

This political focus, and concern with how self-regarding individual behaviour might translate into social, political and cultural improvement, were shared by David Hume, for whom Hutcheson was both mentor and friend. In Chapter 4, Carl Wennerlind explains the focus of Hume's work on the capacity for commercialisation, not only to bring about prosperity, but also to civilise and refine individuals and their society, promoting the conventions which would support government, just as it is government's task to support conventions. Hume understood the real money supply and the interest rate as being endogenous to economic activity and was suspicious of a paper money system (and indeed government debt), which could be abused by government. He built his arguments about causal connection on a broad range of moral, political and economic considerations, drawing on examples from the ancient world.

While Hume arguably had in fact been implicitly referring to the need to 'civilise' the Highlands, against the backdrop of the two Jacobite rebellions of 1715 and 1745, Sir James Steuart was a supporter of the Jacobite cause. As Wennerlind has done with Hume, Andrew Skinner shows in the fifth chapter the cohesion within the corpus of Steuart's work which comes from the derivation of principles from detailed observation. Yet these principles were to be indicative, rather than seen as having any universal validity. Following Hume, he employed a typically Scottish stages theory of development, applying it most notably to his study of population and his theory of demand-led economic growth. His attention to detailed argument about the role of the state, based on his extensive experience on the Continent, may have deterred those who preferred the greater elegance of Smith's work, but enhanced Steuart's influence on the Continent and in the American colonies. 
The Newtonian methodology which Skinner had identified in Steuart is given full treatment by Leonidas Montes, in relation to Adam Smith, in Chapter 6. Rather than implying that the Scottish approach was not distinctive because it derived from Newton, Montes argues that it was in Scotland, with its distinctive philosophical tradition, that Newton was properly understood (hence the reference to Smith as a 'real' Newtonian in the chapter's title). Smith is shown to follow Newton's approach, which contrasted with the deductive axiomatic approach of the French Enlightenment. An open-ended (fallible) system is built on principles which have been drawn from detailed observation, and then subjected to successive refinement.

The distinctive Scottish philosophical tradition which spawned this interpretation of Newton is explored further by Flavio Comim in Chapter 7, where the focus again is on Smith. Comim emphasises the particular importance of the Scottish philosophy of common sense. Common sense played an important part in the origin and derivation of principles, and the understanding of system, in contrast to Descartes's a priori axioms, and a priori understanding of system. Detailed examples were to be used more for illustration than the experimentation of the physical sciences. Hume and Smith thus adapted Newton's notion of experiment for the social sciences. Further, they drew attention to the role of aesthetic judgement, based on experience, as being prior to reason; this contrasted with the conflation of simplicity and elegance with truth in the Cartesian system.

Moving into the nineteenth century, however, we see in James Mill how, under the influence of Ricardo's deductivism and Bentham's utilitarianism, principles grounded in common sense elided into laws of human behaviour, which could then provide the axioms for a deductive system. In Chapter 8 Thomas Torrance shows how James Mill turned his back on the common sense philosophy of his education in Scotland in order to pursue an axiomatic approach. Torrance contrasts this with the historical aspect of the Scottish approach, and subjects both to methodological scrutiny. He illustrates the explanatory weakness of Mill's methodology in terms of his critique of Hume's theory of money, and Malthus's theory of overproduction.

In contrast, while also greatly influenced by Ricardo, John Ramsay McCulloch took the derivation of principles in quite the opposite direction from James Mill, being a great compiler of data. In Chapter 9 D. P. O'Brien shows how McCulloch continued in the Smithian tradition, weaving together a complex picture of a growing economy, paying careful attention to a wide range of institutional and quantitative considerations. A careful account is given of McCulloch's evolving thought on capital and growth; value and distribution; money and trade; and public finance and policy. His economic thought on these matters is shown to be in the Smithian tradition, while reflecting changes to the economy since Smith's time, and also incorporating elements of Ricardo's thought (but never his 
notion of an invariant measure of value, or his theory of comparative cost).

Thomas Chalmers similarly needs to be considered in the context of the developing subject of political economy in Britain, dominated by Ricardo. He too developed the subject, drawing on the Scottish tradition (more influenced, apparently, than James Mill by Dugald Stewart's moral philosophy lectures at Edinburgh), with a focus on social reform and the importance of moral education. In this he displays a characteristically Scottish emphasis on the liberty of the individual in society. In Chapter 10 A. M. C. Waterman emphasises, further, Chalmers's credentials as a classical economist (indeed, as the 'David Ricardo of Scotland'), drawing attention to his contributions to the theory of value and distribution. He was well known, particularly for his experience as a parish minister in implementing his theories of social reform, and his contributions to wider policy debates, but his theoretical contributions received public appreciation only from J. S. Mill. He is best known in fact as leader of the Great Disruption of the Church of Scotland in 1843.

As we proceed through the nineteenth century, the context widens to include North America, where John Rae developed his economic ideas. While these were put forward as a criticism of Adam Smith, Douglas Mair shows, in Chapter 11, that they were nevertheless in the same tradition as Smith. Like McCulloch and Chalmers, Rae drew on statistical evidence, and addressed his arguments to the specific pressing problems of economic development in Canada. He argued that Smith's principle of the division of labour itself required explanation in terms of prior principles, related to the human capacity for invention. Rae also counterposed his thought to that of Smith in that his argument for state intervention to promote invention included the advocacy of judicious barriers to trade.

In the meantime, political economy was emerging in Scotland as a University discipline. In Chapter 12 Alexander Dow and Alan Hutton provide an account of this process, through to the early twentieth century, drawing on university calendars, and focusing on the careers of Nicholson at Edinburgh and Smart at Glasgow. They start by reviewing the history of Scottish political economy over the decades up to1914, during the period when Political Economy was first taught under that name (initially within the Department of Moral Philosophy) in the four ancient Scottish universities (in turn, Edinburgh, St Andrews, Glasgow and Aberdeen). Signs of a continuing Scottish tradition are evident in the emphasis on moral philosophy education alongside political economy, in the emphasis on history of thought, and the orientation towards practical affairs.

In Chapter 13 Alan Hutton brings the account up to the 1950s, focusing on the applied nature of Scottish economics in this period. Because of the greater breadth of Scottish higher education, economics was not taught with a view to specialisation in the discipline until 1945. Up to then it was taught only alongside such subjects as economic history, statistics, 
political science and mercantile law, which contributed to the emphasis on applied economics. This approach was spearheaded in Glasgow, under the influence of Scott and Cairncross, and institutionalised in the 1950s reincarnation of the Scottish Economic Society, and its new journal, the Scottish Journal of Political Economy. The purposes of the Society made specific reference to 'the Scottish tradition of political economy inspired by Adam Smith'. Hutton concludes with a discussion of evidence of decline in that tradition in Scottish universities since the 1950s.

This volume offers a picture of different aspects of Scottish economic thought over the last three centuries. What was the contribution of the Scottish tradition to the human condition, and does it still have some insight for the modern world? We leave that largely for others to assess, but some reflections are offered in the final Postscript chapter by Sheila Dow.

\section{References}

Broadie, A. (2003) The Cambridge Companion to the Scottish Enlightenment, Cambridge: Cambridge University Press: Introduction.

Dow, S. C. (1987) 'The Scottish Political Economy Tradition', Scottish Journal of Political Economy 34, 4: 335-48.

Dow, A. C., Dow, S. C. and Hutton, A. (1997) 'The Scottish Political Economy Tradition and Modern Economics', Scottish Journal of Political Economy 44, 4: 368-83.

— (2000) 'Applied Economics in a Political Economy Tradition: the Case of Scotland from the 1890s to the 1950s', History of Political Economy 32 (annual supplement): 177-98.

- (2003) 'Thomas Chalmers and the Economics and Religion Debate', in D. Hum (ed.), Faith, Reason and Economics, Winnipeg: St John's College Press.

Dow, A. C., Dow, S. C., Hutton, A. and Keaney, M. (1998a) 'Traditions in Economics: the Case of Scottish Political Economy', New Political Economy 3, 1: $45-58$.

- (1998b) 'John Rae and the Scottish Political Economy Tradition', in O. Hamouda, C. Lee and D. Mair (eds), The Economics of John Rae, London: Routledge.

Mair, E. (ed.) (1990) The Scottish Contribution to Modern Economic Thought, Aberdeen: Aberdeen University Press.

Scott, W. R. (1900) Francis Hutcheson: His Life, Teaching and Position in the History of Philosophy, Cambridge: Cambridge University Press.

Skinner, Q. (1969) 'Meaning and Understanding in the History of Ideas', History and Theory 8: 3-53.

— (1988) 'A Reply to my Critics', in J. Tully (ed.), Meaning and Context: Quentin Skinner and his Critics, Oxford: Oxford University Press. 


\title{
2 John Law and the Scottish Enlightenment
}

\author{
Antoin E. Murphy
}

Political economy has always been at the centre of the Scottish Enlightenment. Robertson has contended that 'the most important of all the intellectual preoccupations of the Scottish Enlightenment was political economy' (2000: 51). Writers such as David Hume, Adam Smith and, to a lesser extent, Sir James Steuart ${ }^{1}$ earn pride of place in the Pantheon of Scottish-born economists who contributed to the Scottish Enlightenment. On the other hand John Law has been conspicuously deleted from most discussions of the Scottish Enlightenment. By birth and education Law had strong Scottish credentials. He was born in Edinburgh in 1671, the son of a prominent Edinburgh goldsmith, William Law (d. 1683), who, shortly before he died, had purchased the estates of Lauriston and Randleston, located in the parish of Cramond, which was a few miles outside Edinburgh at the time. Law was educated in Scotland and in 1704/05 attempted to convince the Scottish Parliament of the benefits of his proposed bank. John Law's absence from the list of Scottish intellectuals associated with the Enlightenment raises issues as to why such an important figure has been excluded. At a deeper level his exclusion raises the important question as to just what is meant by the Enlightenment.

In this chapter it will be argued that Law is well worthy of inclusion in the Scottish, and indeed the broader European, Enlightenment. But, once his inclusion is admitted, his theories and policies stand in very distinct contrast to those of Hume and Smith in the area of money and banking. Indeed, it may be contended that at the very heart of the Scottish Enlightenment contribution to political economy there was a schism on the issues relating to the essence and role of money. What is money and what does it do may appear to be very rudimentary questions but the answers to them ranged Law and Sir James Steuart against David Hume and Adam Smith. The analysis of these questions and the respective responses to them by both sides raise a further question about the very conceptualisation of the Enlightenment. Should the Enlightenment be associated with progress and a sense of vision, or does it represent a mere reiteration of conservative ideas by intellectually distinguished writers? This contrast, it is believed, forces the reader to question whether the Enlightenment, from 
a monetary perspective, should be interpreted in terms of the conservative approaches of Hume and Smith or the more visionary stance of John Law. This vision is one that writers of the twenty-first century may find more acceptable than the limited analysis of Hume and Smith. If the true spirit of the Enlightenment's analysis of economic issues involved having some futuristic vision of the way forward, then, it is contended, Law may be lauded for having been considerably ahead of his fellow Scotsmen and he has strong claims to be regarded as more 'enlightened' in the areas of money and banking than Hume and Smith.

The chapter is divided into sections detailing (1) Law's economic theories and policies, (2) Hume and Smith's criticisms of Law, (3) the Scottish Enlightenment writers' exclusion of Law, and (4) the debate over the future role of money and banking.

\section{John Law's economic theories and policies}

John Law was a man considerably ahead of the age he lived in - for a more detailed analysis of his life and System see Faure (1977) and Murphy (1997). His theorising has a very modern resonance and his policy of substituting paper money and bank deposits for metallic money has been vindicated by our current monetary system. The modernism in Law's writings may be seen in the two works that he wrote in 1704 and 1705 . In the manuscript 'Essay on a Land Bank' presented to Lord Godolphin in 1704, published in 1994, and Money and Trade with a Proposal for Supplying the Nation with Money (1705), he used economic terminology that would be associated more with the twenty-first rather than with the eighteenth century. Law was effectively the first economic writer in English to understand and use the economic concept of demand. He analysed the water/diamonds paradox of value, later unashamedly borrowed without acknowledgement by Adam Smith in the Wealth of Nations, in a supply/demand framework. From this start Law went on to analyse inflation in a money supply/money demand framework, long before Milton Friedman produced the 'modern' restatement of the quantity theory in a money supply/money demand framework.

In his 1704 manuscript, 'Essay on a Land Bank' (1994), that addressed monetary issues in England, it appeared that Law was destined to become a pre-monetarist. This did not happen because along the way he had a Pauline conversion when he started to analyse the economic problems in Scotland and later in France. There he identified the problems in the real economy - economic stagnation, unemployment, under-utilisation of resources. In his opinion there was too little money in circulation in the economies of Scotland and France and the monetary system was blocking economic development. Classically minded economists may raise a finger and ask why Law did not contemplate allowing the price mechanism to do its job. He was conscious of the fact that with less money in circulation 
wages and prices could be lower. But he did not believe that lower wages and prices would generate employment without an accompanying injection of money:

It will be asked if countries are well governed why they do not process their wools and other raw materials themselves, since, where money is rare, labourers work at cheap rates? The answer is that work cannot be made without money; and that where there is little, it scarcely meets the other needs of the country and one cannot employ the same coin in different places at the same time.

(Law [1706], emphasis in original)

Thus Law accepted that, with heavy unemployment, wages could move downwards. Nonetheless, he was not prepared to accept that such wage movements would solve the unemployment problem. Instead Law inferred that there was a money-in-advance requirement; money was needed ex ante in order to activate the factors of production. Without it entrepreneurs were not in a position to offer employment even to lowwage-costing labour. Law was suggesting that money was a prerequisite of economic development. He did not believe that money was neutral. For him it played a key role in activating the process of generating more employment and output. Was this inconsistent with his earlier premonetarism? Not necessarily, because Law simply did not believe that either the Scottish economy in 1705 or the French economy in 1716 was at anything near full employment. He felt that income would increase as a result of an expansion of the money supply and that this increase in income would expand the growth in the demand for money. In this way the growth in the money supply would be locked into the economy through the growth in the demand for money. As long as output and employment were below full capacity such increases in the money supply would not have inflationary consequences.

Moving from the specifics of the Scottish economy, Law recognised that there had been an excessive expansion of the money supply at the European (i.e. global) level because of the influx of gold and silver. He stated quite explicitly that the money supply had been increased out of line with the demand for money at the global level and that this had caused inflation.

One finds therefore in Law a hybrid of both pre-monetarist and preKeynesian theorising. He was a pre-monetarist in that he was the first to discuss the concept of the demand for money and the way inflation was determined by the interaction of the money supply with the money demand. His understanding of the way prices had risen in Europe because of the excessive increase in the money supply - caused by silver imports from the Spanish Americas - relative to the demand for money was straightforward monetarism, as was his understanding of the law of one 
price. He was also a pre-Keynesian because he believed that in the specific circumstances of both Scotland and France there was an insufficient supply of money in circulation. Money and trade, the title of his 1705 book, said it all. There was a strong nexus between money and trade. More money was required to produce more trade.

Law's efforts to win over the various potentially interested parties to his banking proposals did not meet with success - the English authorities in 1704, the Scottish Parliament in 1705 and Victor Amadeus, Duke of Savoy, in $1710 / 11$. It was not until 1715 that Law made a breakthrough. Initially, he appeared to have been on the point of persuading Louis XIV to have a bank established, but the death of this monarch, on 1 September 1715, stopped that particular development. Louis XIV's political successor, Philippe duc d'Orléans, Regent of France during the minority of the future Louis XV, soon started to show considerable interest in Law's proposals.

Law in his memoranda of this period showed that he had identified two crises in France, the monetary crisis characterised by the shortage of money and the financial crisis manifested in the very high level of public sector indebtedness. In May 1716 Law started to address the monetary crisis when the Regent permitted him to create the General Bank (Banque Générale). Eschewing his earlier ideas for a land bank, Law initially modelled the General Bank on the Bank of England. Despite a small capital base the bank was successful in issuing banknotes that were convertible into specie.

The success of Law's banking operations, contrasting sharply with the virtual bankruptcy of the French state, encouraged the Regent to permit Law to address the financial crisis. In August 1717 the Company of the West (Compagnie d'Occident) was established. Law used this company to perform two roles: (1) to take over part of the government's short-term floating debt (billets d'état) and (2) to develop the trading potential of French Louisiana - a land mass corresponding to roughly half the United States (excluding Alaska). The capital of the Company of the West, shares of 500 livres each, was subscribed for in billets d'état. These first shares in the company came to be known as mères (mothers). As the billets d'état were standing at a very heavy discount - up to 70 per cent - because of the government's inability to service the national debt, the original shareholders of the Company were able to buy shares at a price of around 150 livres each. Law used the Company of the West as a take-over vehicle. It took over the other trading companies, the tobacco farm, and the rights to the Mint. Then in August 1719 he announced the most grandiose part of his debt management operations, namely the take-over of all the national debt. This was achieved through the issue of the soumissions, shares with a price of 5,000 livres in September/October 1719.

The issues of mères, filles (daughters), petites filles (granddaughters) and soumissions produced a frenzy of stock market activity so that, at the height of the Mississippi stock market in late 1719 and early 1720, the Company's 
shares were priced at over 10,000 livres. Investors flocked to the rue Quincampoix in Paris to trade in the paper of the Mississippi Company. By early January 1720 Law was regarded as a financial genius in France and the Regent rewarded him for his policies by appointing him Controller General of Finances, the equivalent of Prime Minister. The British ministers concerned at France's new-found success decided to copy Law's debt management policy by using the South Sea Company as a vehicle for transforming government debt into equities. This gave rise to the South Sea Bubble of 1720 .

Unfortunately for Law he over-monetised the French economy so that the financial circuit that he had created, comprising paper money and shares, became too great relative to the size and growth potential of the real economy. The System collapsed in the latter half of 1720 and Law had to depart quickly from France in December to escape from the wrath of disappointed shareholders.

\section{Law's exclusion by the Scottish Enlightenment writers}

Law had come into economics with a past. When he approached the Scottish Parliament with his ideas for a land bank in 1705, the whispering in Edinburgh concerned his activities as a rake, a philanderer, a gambler and, even worse, a murderer and an escapee from prison, in London. Here was a man who had squandered part of his inheritance, murdered his fellow 'beau', Edward Wilson, in a duel, been sentenced to death and avoided the scaffold by escaping from prison with the connivance of ministers of the English government of the time. This was not the type of curriculum vitae that endeared him to many of the Scottish parliamentarians. William Greg, writing from Edinburgh to Robert Harley on 9 June 1705, gave details on Law's background:

a homespun [project] is set afoot here by a gentleman who of all men living once was thought to have the worst turned head that way. $\mathrm{Mr}$ Law who killed Beau Wilson in England is the man, and so fond is the Commissioner of his project for a Land Bank (since money fails) that the day before yesterday his Grace sent for the quondam rake in order to discourse him fully upon this important point, so very necessary at this time.

(HMC 1705: 195)

To encourage the Scottish Parliament to react positively to his land bank proposal, Law arranged for his aunt's publishing house to print Money and Trade in 1705. Though the Parliament considered Law's proposals it did not accept them, and, once the Act of Union came into force in 1707, Law was forced to flee from Edinburgh as a man on the run from British justice. 


\section{Antoin E. Murphy}

Law's reputation deteriorated further in many Scottish eyes when he failed as a policy maker in France in 1720 and was once again forced to move quickly out of France to escape from disgruntled investors of his Mississippi System. The collapse of the System led to the lampooning of Law by satirists and engravers. Montesquieu devoted one of the Persian Letters to ridiculing Law, comparing him to Aeolus, the god of wind, while the Dutch engravers made massive profits out of the satirical and, in many cases, scatological prints of the System in Het Groote Tafereel der Dwaasheid (1720). On every occasion when there was a whiff of financial scandal in the eighteenth century, the publishers reprinted this work to remind the European public of the excesses of the Mississippi System. Law, the Scottish murderer, the rake and philanderer, was now also the failed policy maker. Establishing intellectual links with such an individual was not, apparently, to the taste of two of Scotland's greatest Enlightenment writers, David Hume and Adam Smith.

\section{Law, Hume and Smith}

Early memoranda written by David Hume, edited by Mossner (1948), show that he read John Law's Money and Trade some time between 1737 and 1740. Mossner also shows that Hume read Du Tot's Réflexions politiques sur les finances et le commerce (1738) during this period. Nicolas $\mathrm{Du}$ Tot was the under-treasurer of Law's Royal Bank for most of 1720. He wrote copiously on Law's System - see Du Tot (1738, 1935, 2000) - attempting to encourage interest in Law's theories and policies. His Réflexions were written to counter some of the ideas presented by John Law's former secretary, Jean-François Melon, in his Essai politique sur le commerce (1734). Footnotes in his essays 'Of Money' and 'Of Public Credit' show that Hume was familiar with the three works of Melon, Du Tot and Pâris-Duverney. The latter had written a work criticising Du Tot with the title Examen du livre intitulé Réflexions politiques sur les finances et le commerce (1740). Hume was not only familiar with Money and Trade but he had read the three works analysing Law's economic policies by Melon, Du Tot and Pâris-Duverney. Law's influence was even deeper, particularly if one accepts Robertson's view that Hume's Political Discourses were written:

as a systematic response to contemporary French political economy and particularly Jean-François Melon's Essai politique sur le commerce... against Melon's model of an economy in which agriculture was primary, requiring all other branches of economic activity to be subordinated to its demands, Hume offered one in which commerce itself was the agent of development, and its chief obstacles were jealousy of trade and the misuse of its instruments, money and credit.

(Robertson 2000: 51) 
If Melon was the catalyst for Hume, it must also be accepted that Law was very much involved in indirectly inspiring Hume, because he had been the catalyst for Melon's Essai politique sur le commerce. Despite the massive presence of Law in Melon, Du Tot and Pâris-Duverney's works and Hume's reading of Money and Trade, there is only one specific mention of Law in the Political Discourses and that is in a footnote in 'Of the Balance of Trade'. Furthermore, and tellingly, Hume, in this one unique mention of Law, cited him as a 'foreign writer' (1752: 126) alongside the French writers, Melon and Du Tot. Technically speaking Hume was correct in that Law had become a French national during the System, but Hume's disavowal of Law's Scottish background is indicative of the extent to which Hume disapproved of Law and wanted to dissociate him from Scotland's literary output.

Hume's views on the role of money and the misuse of money and credit are to be clearly seen in his essays 'Of Money' and 'Of the Balance of Trade' in the Political Discourses. The opening lines of his essay 'Of Money' showed that he intended adopting a very classical approach in giving money no real role in the economy:

Money is not, properly speaking one of the subjects of commerce but only the instrument which men have agreed upon to facilitate the exchange of one commodity for another. 'Tis none of the wheels of trade: 'Tis the oil which renders the motion of the wheels more smooth and easy.

(Ibid.: 41)

So for Hume money was not the 'wheels of trade' but merely a lubricant to facilitate trade. He quickly reiterated this view, stating that money was just a numeraire: 'money is nothing but the representation of labour and commodities, and serves only as a method of rating or estimating them' (ibid.: 46).

However, more detailed analysis of Hume's thought shows that, although he appeared to start out in a clear classical fashion on the neutrality of money, he then started to hesitate and to equivocate. The first equivocation was his acknowledgement that the discovery of mines in South America in expanding the money supply had helped increase economic activity in Europe:

Accordingly we find, that in every kingdom, into which money begins to flow in greater abundance than formerly, every thing takes a new face; labour and industry gain life; the merchant becomes more enterprising, the manufacturer more diligent and skilful, and even the farmer follows his plough with greater alacrity and attention.

(Ibid.: 46-7) 
So Hume, despite his opening classical salvo on the role of money, was prepared to allow that money could have real effects on the economy. However, these real effects were limited to the short run and, in the long run, the increase in the money supply was perceived as having undesirable inflationary effects. Hume did leave a window of opportunity for money, contending that it was always better to have the money supply increasing rather than falling. On this issue he used Du Tot's work to show how a small depreciation of the currency could have positive real effects on the economy because of the 'illusion' (money illusion?) that it created in the public's mind that it had more money. Hume's equivocation on the role of money was further borne out by his response in a letter to James Oswald when he remarked:

I agree with you, that the increase of money, if not too sudden, naturally increases people and industry, and by that means may retain itself; but if it do not produce such an increase, nothing will retain it except hoarding.

(Hume 1750: 197-8)

The equivocations in 'Of Money' as to whether there was a real role for money to play in the economy reappeared in another shape in his essay 'Of the Balance of Trade'. In this case the equivocation related to the role of paper credit, banknotes and other financial instruments. One moment Hume was railing against paper money and the next instance praising it. In 'Of Money' he had blamed the increase in prices on banks and paper credit remarking 'This [the dearness of prices] has made me entertain a great doubt concerning the benefits of banks and paper credit' (Hume 1752: 43). However, Hume faced a dilemma, for at the time of writing the Political Discourses the Scottish banks were showing considerable dynamism in the area of credit expansion through the development of an overdraft system. Hume had enormous difficulty in grasping the extent of the financial revolution that was happening around him. He could see certain benefits accruing from the use of paper money and credit, but he still, doggedly, wanted to maintain his belief that metallic money was the base on which the system revolved and that 'it is impossible to heap up money, more than any fluid, beyond its proper level' (ibid.: 64).

Hume was careful to emphasise that his concept of 'level' (equivalent to the demand for money) meant 'the proportion of the labour and commodities which are in each province'. The problem with banks and financial innovation was that they could cause money to sink below this 'level': 'I scarcely know any method of sinking money below its level, but those institutions of banks, funds, and paper-credit which are so much practised in this kingdom' (ibid.: 89).

Though he was prepared to discuss the use of 'bank credits' (overdrafts) and the issuance of small denomination banknotes by the Scottish banks, 
Hume pulled back from recognising their benefits. Instead he emphasised their dangers: 'But whatever other advantages result from these inventions, it must still be allowed that, besides giving too great facility to credit, which is dangerous, they banish the precious metals' (Hume 1750: 71-2).

Hume was not prepared to give banks any significant role in the economy. In a letter to Montesquieu in 1749 he had earlier written, 'Banks are convenient, but it may be questioned whether they are of very much value' (ibid.: 188). Later he disdainfully dismissed the business of banks, remarking that 'our darling projects of paper credit are pernicious' (Hume 1752: 92).

In 'Of Public Credit' Hume reinforced this image of a conservative prepared to find fault with any type of financial innovation such as the creation of the public debt. He showed a deep hostility to capital markets and their practitioners, suggesting that their activities in Change Alley, the stock exchange of the day, produced nothing:

But what production we owe to Change-alley, or even what consumption, except that of coffee, and pen, ink and paper, I have not yet learn'd; nor can one foresee the loss or decay of any one beneficial commerce or commodity, tho' that place and all its inhabitants were for ever bury'd in the ocean.

(Ibid.: 127)

These were strong words, suggesting that Hume could envisage the economy suffering no loss if the stock exchange was suddenly destroyed. He observed that government debt was becoming a type of money: 'Public securities are with use become a kind of money...' (ibid.: 128). He wrote that 'public stock' was similar to 'being a kind of paper-credit', having:

all the disadvantages attending that species of money. They banish gold and silver from the most considerable commerce of the stated, reduce them to common circulation, and by that means render all provisions and labour dearer than otherwise they would be.

(Ibid.: 131)

Hume's antipathy to Law became even clearer when he directed his attack at Law's attempts to solve France's national debt problems:

'tis not altogether improbable, that, when the nation become heartily sick of their debts, and are cruelly opprest by them, some daring projector may arise, with visionary schemes for their discharge. And as public credit will begin, by that time, to be a little frail, the least touch will destroy it, as happen'd in France; and in this manner, it will dye of the doctor.

(Ibid.: 136, emphasis in original) 
Terms such as 'daring projector' and 'visionary schemes' were intentionally hostile to Law. Hume wanted nothing to do with Law. He believed Law had been a failure in his understanding of money and credit and his policy of attempting to correct the French national debt. Implicitly he was highly critical of someone who demonetised gold and silver, expanded the money supply and was involved in debt management. Hume was a metallist, was critical of expansionary monetary policy and believed that the national debt was prima facie a bad development.

So government securities were added to paper credit in Hume's list of financial instruments that would lead to the banishment of metallic money from the economy. If Hume had been in Law's position his writings indicate that he would have shut down the banking system, abolished government securities and closed the stock exchange. It is very much to be doubted that such a conservative writer on money and finance would ever have found any way to understand John Law's theories and policies.

Like Hume, Smith showed an interest in Law from an early stage in his career. In his Lectures on Jurisprudence (1978) he produced a peremptory analysis of Law's theory alongside a quick assessment of the Mississippi System. He criticised Law for linking wealth (national opulence) with money and for his belief that paper money could replace specie:

The last bad effect that shall be taken notice of is the notion of $\mathrm{Mr}$ Law, a Scotch merchant. He thought that national opulence consists in money, and that the value of gold and silver is arbitrary and depends on constitution and agreement. He imagined that the idea of value might be brought to paper, and it preferred to money. If this could be done, he thought it would be a great convenience, as the government then might do what it pleased, raise armies, pay soldiers, and be at any expense whatever. Mr Law proposed his scheme to the Scotch Parliament in 1701.

(Ibid.: V, 271)

Note Smith's use of the term 'imagined' when referring to Law's ideas in the above quotation. He would use the same verb later in the Wealth of Nations when criticising Law. A couple of pages later in the Lectures Smith repeated his earlier criticisms:

This amazing scheme was founded on these two principles, that public opulence consists in money, and that the value of money is arbitrary, founded upon the common consent of mankind. Consistent with these principles he thought he might easily encrease the public opulence if he could annex the idea of money to paper, and the government could never be at any loss to produce any effect that money could do.

(Ibid.: V, 281) 
Smith's first criticism of Law, that of linking wealth with money, was unfounded. Law understood the difference between wealth and money. Law did, however, believe that money helped create wealth by driving the trade of the nation. Smith's second criticism of Law, that of believing that paper money could act as money, represented a fundamental division of opinion between the two Scotsmen that will be developed below.

Smith's attempt to provide a short account of the Mississippi System is full of errors and shows how little he understood it. In his discussion of the company's share issues, he missed out the issues of the filles and petitesfilles. He also, mistakenly, indicated that there was a share issue of 10,000 livres (perhaps he was confusing the options issue of January 1720 with the issue of shares) (ibid.: V, 276). Smith summarised Law by maintaining that he was his own fool:

This scheme of Mr Laws was by no means contemptible; he realy believed in it and was the dupe of it himself. It was thought he had provided well for himself, but it was found to be otherways. If the Duke of Orleans had lived only a few days longer, it was agreed upon that he was to have been re-established. After his death it was not thought expedient to have it put in execution.

(Ibid.: V, 281)

Between Smith's presentation of the lectures, that would be retrospectively published as the Lectures on Jurisprudence, and the writing of the Wealth of Nations, Scotland had suffered a major banking crash, that of the Ayr Bank in the summer of 1772. This crash would further jaundice Smith's views on the role of banks and paper money. He was not only prepared to criticise Law but to blame him in part for having inspired some of the dangerous views on money and banking that had led to the collapse of the bank:

That the industry in Scotland languished for want of money to employ it, was the opinion of the famous Mr Law. By establishing a bank of a particular kind which he seems to have imagined, might issue paper to the amount of the whole value of all the lands in the country, he promised to remedy this want of money.... The idea of the possibility of multiplying paper money to almost any extent, was the real foundation of what is called the Mississippi scheme, the most extravagant project both of banking and stock-jobbing that, perhaps, the world ever saw... The splendid, but visionary ideas which are set forth in that [Money and Trade] and some other works upon the same principles, still continue to make an impression upon may people, and have, perhaps, in part, contributed to that excess of banking which has of late been complained of both in Scotland and in other places.

(Smith 1776: II.ii.78) 
Aside from Smith's linking of Law's ideas with those that had produced 'an excess of banking' he also criticised Law for 'imagining' his banking ideas and producing the 'most extravagant project both of banking and stockjobbing that, perhaps, the world ever saw'. It may be contended that Smith qualified his criticisms of Law by referring to the 'splendid but visionary ideas' of Money and Trade - shades of Hume's comment about 'some daring projector' with 'visionary schemes'. Alas, 'visionary' had pejorative connotations suggesting instability and absence of reality. Smith was not an admirer of Law. The suspicion is that, like Hume, he had major problems attempting to understand Law because of his own limitations in understanding the role of money. This may be clearly seen when Smith discussed the substitution of paper money for specie in the economy. Initially, he showed the sizeable benefits that could flow from substituting the metallic 'wheel of circulation' with a paper 'wheel'. If properly managed this substitution could produce an expansion in the capital base of the economy as the substituted specie was used to purchase capital goods overseas. But then the alarm bells went off in Smith's mind and the equivocations about the usefulness of paper money and credit come to the fore just as they had with his friend David Hume. Having shown how the use of paper money, in liberating specie for the purchase of capital goods, was analogous to the provision of a 'new highway through the air' that would liberate a scarce factor of production, land, for other uses, Smith hesitated, equivocated and allowed his inner fears with respect to paper money to come to the fore. This type of operation brought the economy too close to the sun:

The judicious operations of banking, by substituting paper in the room of a great part of this gold and silver, enables the country to convert a great part of this dead stock into active and productive stock; into stock which produces something to the country.... The judicious operations of banking, by providing, if I may be allowed so violent a metaphor, a sort of wagon-way through the air; enable the country to convert, as it were, a great part of its highways into good pastures and corn fields, and thereby to increase very considerably the annual produce of its land and labour. The commerce and industry of the country, however, it must be acknowledged, though they may be somewhat augmented, cannot be altogether so secure, when they are thus, as it were, suspended upon the Daedalian wings of paper money, as when they travel about upon the solid ground of gold and silver.

(Ibid.: II.ii.86)

The contrast between the 'Daedalian wings of paper money' and the 'solid ground of gold and silver' is striking. Though recognising some of the benefits of banking, Smith's strong metallist position was personified in the 'solid ground' of metallic money. He feared bankers, or, at least, 
certain types of bankers. He referred to the 'over-trading of some bold projectors' which caused an excessive circulation of money in both Scotland and England (ibid.: II.ii.304). Smith had seen bank failures in Scotland and in 1772 there was a major banking crisis on the whole island with Hume writing to Smith that 'even the Bank of England is not entirely free from suspicion'. He was especially critical of the Ayr Bank, which was more 'liberal than any other had ever been' and 'seems to have made scarce any distinction between real and circulating bills' (ibid.: II.ii.73).

Hont summarised Smith's strong opposition to John Law:

In ruling out John Law's strategy of paper money and banks as instruments of development (since they raised the amount of money in the country over its natural level and thus undermined the low-cost, lowwage advantages of the poor country), he was not simply adopting a firm position against the use of credit and paper money in the ideological context of the Mississippi and South Sea bubbles and the new mobile property of the 'Financial Revolution'. He was also arguing against Law's heritage as it survived in 'our darling projects of paper credit' in Scotland.

(Hont 1983: 277)

Hume and Smith's opposition to banknotes, paper credit and financial innovation in general may have been initially fashioned by the collapse of Law's System in France and the attendant difficulties resulting from the South Sea Bubble in London. The more recent failure of the Ayr Bank stiffened Smith's opposition to a new monetary system. Hume and Smith's strong opposition to Law and his approach to monetary economics has apparently influenced most recent commentators in that they have tended to exclude Law and his ideas from their analysis of the Scottish Enlightenment.

\section{Law's exclusion by writers on the Scottish Enlightenment}

The term 'the Scottish Enlightenment' was coined by William Robert Scott in his biography of the Irishman Francis Hutcheson: His Life, Teaching and Position in the History of Philosophy (1900). The term gained currency some forty years ago through the work of Hugh Trevor-Roper and Duncan Forbes, both of whom according to Robertson (2000: 37) claimed paternity for the Scottish Enlightenment 'as a distinct subject of scholarship'. Since then there has been an impressive range of books and articles published on the subject.

When consulting these works it becomes immediately apparent that Law received scant attention from most writers on the Scottish Enlightenment. Chitnis (1976: 9) in The Scottish Enlightenment: A Social History chided writers on the Scottish Enlightenment for neglecting the roles of Sir James 
Steuart's Inquiry into the Principles of Political Economy (1767) and Lauderdale's Inquiry into the Nature and Origin of Public Wealth (1804). However, he failed to list for possible inclusion John Law. Robertson in the New Palgrave (1987) article on the 'Scottish Enlightenment' included Hume, Steuart and Smith in the Scottish Enlightenment, but, again there is no mention of Law. A series of essays The Scottish Enlightenment: Essays in Reinterpretation edited by Wood (2000) makes no reference to Law. Alexander Broadie (2001) in a book with the title The Scottish Enlightenment never mentions Law. A Japanese study, The Rise of Political Economy in the Scottish Enlightenment, edited by Tatsuya Sakomoto and Hideo Tanaka (2003), whilst covering, inter alia, the contributions of Andrew Fletcher, Robert Wallace, Lord Kames, William Robertson, John Millar and Dugald Stewart, makes no reference to Law. Checkland (1975) and Hont (1983) are two notable exceptions to this phenomenon.

It is not intended here to present a comprehensive bibliography of all the works on the Scottish Enlightenment and to consider whether they made reference to Law or not. However, these recent publications that have just been listed are believed to be indicative of the very considerable neglect of Law. It may of course be argued that Law lived in a period prior to the Scottish Enlightenment. He died in Venice in 1729 at a time when some commentators have detected the first shoots of the Enlightenment emerging through the work and teaching of Francis Hutcheson. It could also be argued that the main thrust of the Scottish Enlightenment was a philosophical one and that therefore Law's work would not have served as an intellectual trampoline for the philosophers of the Enlightenment. However, the willingness of commentators to concentrate, not just on the philosophical contributions of Hume and Smith, but also on their economic contributions in the former's Political Discourses (1752) and the latter's Wealth of Nations (1776) indicates that political economy has come to be regarded as a key part of the Scottish Enlightenment. The Wealth of Nations has been presented by many to be the jewel in the crown of Scottish Enlightenment studies. Robertson (1987) wrote of it: 'Adam Smith's Wealth of Nations (1776) so outshone all other that it seemed to establish political economy as a science in its own right' (1987: iv, 271).

It appears to me that there are deeper reasons for Law's exclusion, revolving around his suitability to be presented as a representative of the Enlightenment. As shown above Law's multiple-faceted background combining elements of philandering, murder and gambling did not endear him to Edinburgh society in 1705 . How could genteel society interested in 'sociability' associate itself with such a man? Law did not emanate from the background of the traditional Scottish Enlightenment thinker. Robertson has argued that, with the exception of David Hume, 'all those who associated themselves with the Enlightenment made successful careers in one or more of the three institutions at the center of Scottish public life: the universities, the church, and the law' (2000: 42). Law was certainly 
another exception. He did not go to university, he changed his religion and had no legal connections. His method of making money in his early days as the equivalent of an eighteenth-century bookmaker further distanced him from these professions. For a short period it seemed as if Law was able to surmount his shady background with his successes in France winning him a temporary reprieve. Alas, his reputation fell further when the Mississippi System and the South Sea Company, fashioned on Law's French model, crashed so spectacularly in 1720. People associated with financial failures of such magnitude earn a very bad press. There is reluctance to be associated with them. Hume and Smith had no wish to be linked with Law and, as shown above, they were highly critical of him. Even John Maynard Keynes, when it came to looking for intellectual predecessors, would not cite Law in chapter 23 of the General Theory of Employment, Interest and Money (1936). Keynes mentioned Law twice in the Treatise on Money (1930) but he omitted him from the General Theory even though Law was the closest to him as an antecedent. Keynes's dilemma was easy to see. If he cited Law as an intellectual predecessor then critics would have pointed to Law's failures as a policy maker. Keynes did not want his theories and policies to be associated with failure. So instead of choosing Law as a natural antecedent he opted to associate his theory with the mercantilists and made no reference to Law.

\section{The debate on the role of money and banking}

Hont (1983) has argued that there was a distinct 'rich country-poor country' debate in eighteenth-century Scottish political economy. In my opinion, an equally important debate was that concerning the role of money and banking. Scotland had been a key country for the emergence of the new order relating to money and banking. It was the birthplace of William Paterson, the founder of the Bank of England. The Bank of Scotland (1695) had been founded just one year after the Bank of England. In the first half of the eighteenth century two other limited liability joint stock banks, the Royal Bank of Scotland (1727) and the British Linen Company (1746), had been established. This meant that, by the time Hume came to write the Political Discourses, Scotland had three highly successful joint stock banks compared with just one, the Bank of England, south of the border. Scotland's banking system produced, according to Smout, 'a fifteenfold growth of note issue between 1744 and 1772' (1983: 70). Paper money and banking were not just in the air, they had become an integral part of the Scottish monetary system.

Law had introduced the theoretical basis for the assessment of money, banks and paper credit in his 'Essay on a Land Bank' (1704) and Money and Trade (1705). Hume countered this in the Political Discourses; Sir James Steuart in turn countered Hume in his Inquiry, and then Smith, pointedly ignoring Steuart, dismissed Law peremptorily in the Wealth of Nations. 
Hume and Smith both misunderstood and feared the newly emerging monetary system.

In particular they did not grasp two of the key elements relating to money and banking that Law had introduced in both his theoretical works and his application of these as monetary policies. These were (1) the nature of money and (2) the influence of money.

Unlike Hume and Smith, Law did not believe that money had to be intrinsically valuable. Instead of arguing that money is the value for which goods are exchanged, Law replaced the preposition 'for' with the preposition 'by' to argue that 'money is the value by which goods are exchanged'. In this way Law contended that there was no point keeping money in a metallic straitjacket subject to the vicissitudes of the discoveries of gold and silver and the vagaries of shifts in demand across the globe. This was allowing the randomness of these discoveries and shifts in global demand to determine the value and size of the circulating medium of exchange in Europe. Law believed that it was possible to control a country's economic destiny by substituting paper money for metallic money. This did not mean to say that paper money was valueless. As paper it was, but the promissory nature of the words on it made it acceptable as money, i.e. it represented value through the conventional perception of its asset backing. Law understood that, in order to have confidence in a paper currency, people had to understand that it had proper asset backing. Initially this was to be in the form of land under his land bank proposals, but, as his ideas evolved, he understood that the backing could be in the form of assets such as government securities and loans to the private sector. With good asset backing it was not necessary to have metallic money.

Once the debate moves to this level, the potential for using the banking system and its credit-creating potential are great. Money can be used to have a real effect on economic activity. The problem of metallism is that it created the mentality that investment could take place only through savings. This meant that pieces of gold and silver had to be withdrawn from consumption expenditure and channelled towards investment. Investment therefore implied abstinence from consumption expenditure. The newly evolving world of money, banking and financial innovation through the capital market raised serious question marks about this very limited approach to corporate financing. Banks and capital markets were excluded from the process. Yet it was evident that the practitioners of the new methods of corporate financing could produce alternative ways to finance investment than the savings/abstinence channel. People could save with banks but these very institutions had the capability of expanding credit by some multiple of the initial deposits they received. This was the potential of a credit-creating banking system. Law had the vision to understand the full potential of such a system. Hume, Smith, their contemporary Turgot in France, and indeed most economists until the twentieth century did not. 


\section{Conclusion}

The genius of Law was that he was not only able to conceive a credit-creating specieless system, but he was also capable of making it operational. Nicolas Du Tot, the under-treasurer of the Royal Bank, wrote at the time that posterity would not believe that, for a time, Law successfully created a system in which people did not wish to use either gold or silver. While Law's System ultimately failed, his fellow Scotsmen pioneered the development of banking in Scotland. Checkland (1975) has shown the sophistication of these bankers. Despite the vision of a specieless monetary system that Law had temporarily created, and the evolution of Scottish banking towards such an eventuality through the eighteenth century, David Hume and Adam Smith were not fully able to grasp the extent of the monetary revolution that was taking place under their very eyes. Both equivocated when it came to analysing this new world of money and banking. So, from this monetary perspective, who were the 'enlightened' writers? Were they Hume and Smith, ever fearful of the new monetary system under construction, or Law and his successors, the Scottish bankers, with their vision and endorsement of a world of banks, paper credit and financial innovation?

\section{Note}

1 The link between Sir James Steuart and John Law is an important one and, hopefully, will be the basis of a later paper.

\section{References}

Broadie, Alexander (2001) The Scottish Enlightenment, Edinburgh: Birlinn.

Checkland, S. G. (1975) Scottish Banking A History, 1695-1973, Glasgow and London: Collins.

Chitnis, Anand C. (1976) The Scottish Enlightenment: A Social History, London: Croom Helm.

$\mathrm{Du}$ Tot, [Nicolas] (1738) Réflexions politiques sur les finances et le commerce, The Hague: Les Frères Vaillant \& Nicolas Prevost.

— (1935) Réflexions politique sur les finances et le commerce. Édition intégrale, edited by Paul Harsin, Paris: Faculté de Philosophie et Lettres de l’Université de Liège.

— (2000) Histoire du système de John Law 1716-1720, edited by Antoin E. Murphy, Paris: INED.

Faure, Edgar (1977) La Banqueroute de Law, Paris: Gallimard.

HMC ([1705] 1901) Report on the Manuscripts of his Grace the Duke of Portland, London: HMC.

Hont, Istvan (1983) 'The "Rich Country-Poor Country" Debate in Scottish Classical Political Economy', in Hont and Igantieff (1983).

Hont, Istvan and Ignatieff, Michael (eds) (1983) Wealth and Virtue: The Shaping of Political Economy in the Scottish Enlightenment, Cambridge: Cambridge University Press. 
Hume, David ([1750] 1970) 'Hume's Reply to Oswald', reprinted in Eugene Rotwein (ed.), David Hume: Writings on Economics, Madison WI: University of Wisconsin Press.

— ([1752] 1970) Political Discourses, Edinburgh, reprinted in Eugene

Rotwein (ed.), David Hume: Writings on Economics, Madison WI: University of Wisconsin Press.

Keynes, John Maynard (1930) A Treatise on Money, London: Macmillan.

- (1936) The General Theory of Employment, Interest and Money, London: Macmillan.

Lauderdale, Earl of (1804) An Inquiry into the Nature and Origin of Public Wealth, Edinburgh: Constable; London: Longman.

Law, John ([1704] 1994) John Law's Essay on a Land Bank, edited by Antoin E. Murphy, Dublin: Aeon Publishing.

— ([1705] 1934) Oeuvres complètes, edited by Paul Harsin, Paris: Librairie du Recueil Sirey.

— ([1706]) 'Mémoire touchant les monoies et le commerce', Paris: Archives nationales, 1468 , ms. 113 , fo. 7 .

Melon, Jean François (1734) Essai politique sur le commerce (n.l.)

Montesquieu, Charles-Louis de Secondat ([1721] 1987) Persian Letters, English translation, Harmondsworth: Penguin.

Mossner, Ernest C. (1948) 'Hume's Early Memoranda, 1729-1740: the Complete Text', Journal of the History of Ideas 9, 4: 492-518.

Murphy, Antoin E. (1997) John Law: Economic Theorist and Policy Maker, Oxford: Oxford University Press.

Pâris-Duverney, Joseph (1740) Examen du livre intitulé Réflexions politiques sur les finances et le commerce, The Hague: Les Freres Vaillant \& Nicolas Prevost.

Robertson, John (1987) 'The Scottish Enlightenment', in John Eatwell, Murray Milgate and Peter Newman (eds), The New Palgrave: A Dictionary of Economics, London: Macmillan.

- (2000) 'The Scottish Contribution to the Enlightenment', in Wood (2000).

Sakamoto, Tatsuya, and Tanaka, Hideo (2003) The Rise of Political Economy in the Scottish Enlightenment, London: Routledge.

Scott, William Robert (1900) Francis Hutcheson: His Life, Teaching and Position in the History of Philosophy, Cambridge: Cambridge University Press.

Smith, Adam ([1776] 1978) 'Report Dated 1766', Lectures on Jurisprudence: The Glasgow Edition of the Works and Correspondence of Adam Smith, edited by R. L. Meek, D. D. Raphael and P. G. Stein, Oxford: Oxford University Press.

- ([1776] 1976) An Inquiry into the Nature and Causes of the Wealth of Nations, Glasgow Edition, edited by R. H. Campbell, A. S. Skinner and W. B. Todd, Oxford: Oxford University Press.

Smout, T. C. (1983) 'Where had the Scottish Economy got to by the Third Quarter of the Eighteenth Century?', in Hont and Ignatieff (1983).

Steuart, Sir James (1767) An Inquiry into the Principles of Political Economy, London.

Wood, Paul (ed.) (2000) The Scottish Enlightenment: Essays in Reinterpretation, Rochester NY: University of Rochester Press. 


\title{
3 Francis Hutcheson, 1694-1746 ${ }^{1}$
}

\author{
Andrew S. Skinner
}

Hutcheson was born on 8 August 1694. His father, John, was a Presbyterian minister in Armagh, Ireland, and Francis spent his early years at nearby Ballyrea. In 1702 Francis and his elder brother, Hans, went to live with their grandfather, Alexander Hutcheson, at Drumalig in order to further their schooling. At the age of fourteen Francis moved to a small denominational academy at Killyleagh, County Down.

In 1711 Hutcheson matriculated at Glasgow University, where he was particularly influenced by Robert Simpson (Mathematics), Gerschom Carmichael (Moral Philosophy), Alexander Dunlop (Greek) and John Simpson (the 'heretical divine'). Hutcheson graduated in 1713 and embarked upon a course of study in theology under Simpson's guidance.

Hutcheson was back in Ireland in 1719 when he was licensed as a probationary minister but moved to Dublin where he established an academy of which he remained head until 1730. His reputation established, Hutcheson was elected to the Chair of Moral Philosophy in Glasgow, succeeding Carmichael. It was as a lecturer that he made his mark, brilliant and stylish, using English rather than Latin. Hutcheson's career as author and teacher amply confirms Adam Smith's famous reference to the 'abilities and virtues of the never-to-be-forgotten' master (Smith 1977: 309).

Hutcheson lectured five days a week on Natural Religion, Morals, Jurisprudence, and Government - an order which was to be followed by Adam Smith on his appointment to the Chair of Moral Philosophy in 1752. On three days he lectured on classical theories of morality, thus contributing (with Dunlop) to a revival of classical learning in Glasgow, which formed an important channel for stoic philosophy, a philosophy which was to have an important influence on Adam Smith. Hutcheson died on 8 August 1746 (his birthday) and was buried in St Mary's churchyard in Dublin.

\section{Social order}

Although this chapter is concerned primarily with Hutcheson's economic analysis it will be convenient to say a little regarding his ethical work. 
Adam Smith identified two key questions which the moral philosopher must confront. First, wherein does virtue consist, and, second:

how and by what means does it come to pass, that the mind prefers one tenor of conduct to another, denominates the one right and the other wrong; consider the one as the object of approbation, honour and rewards, and the other of blame, censure and punishment.

(Smith 1759: VII.i.2)

Hutcheson addressed both questions, identifying virtue with benevolence while explaining the processes of judgement in terms of a particular sense, the 'moral sense'. Smith was to reject Hutcheson's answer to the first question on the ground that, while important, the emphasis on benevolence neglected the role of self-command and the 'inferior' virtue of prudence. In the same way, while welcoming his master's emphasis on sentiment rather than reason in explaining the means by which the mind forms judgements concerning what is fit and proper to be done or to be avoided, Smith rejected the notion of a special (internal) sense (see, for example, Skinner 1996: ch. 3).

The common element evident in the work of Hutcheson, Hume and Smith is the emphasis on sentiment. But they also share another preoccupation, namely the attempt to explain the origins of social order: a crucially important element in the treatment, inter alia, of economic phenomena. The basic task was to explain how it was that a creature endowed with both self- and other-regarding propensities was fitted for the social state.

When we turn to Hutcheson it is to discover marked similarities with the work of his successor, especially in the context of his belief that 'We may see in our species, from the very cradle, a constant propensity to action and motion' (Hutcheson 1755: 21). But in some respects the position is subtler than that stated by Smith. To begin with, Hutcheson argued that man has powers of perception which 'introduce into the mind all the materials of knowledge' and which are associated with 'acts of the understanding' (ibid.: 7). Acts of the understanding assist in the isolation of objects to be attained (for example, sources of pleasure) or to be avoided, and culminate in acts of will.

Acts of will, which may be calm or turbulent, were divided in turn into the selfish or the benevolent. Benevolent acts of will which may be described as calm tend towards the 'universal happiness of others', while the turbulent include 'pity, condolence, congratulation, gratitude'. Acts of will which are selfish but calm include 'an invariable constant impulse towards one's own perfection and happiness of the highest kind' (ibid.: 9) and do not rule out 'deliberate purposes of injury' (ibid.: 73). The turbulent and selfish embrace 'hunger, thirst, lust, passions for sensual pleasure, wealth, power or fame' (ibid.: 11-12). 
In Hutcheson's case, the problem is that of attaining a degree of balance between the turbulent and the calm, the selfish and the benevolent:

the general tenor of human life is an incoherent mixture of many social, kind, innocent actions, and of many selfish, angry, sensual ones; as one or other of our natural dispositions happens to be raised, and to be prevalent over others.

(Ibid.: 37)

While Smith was correct in identifying Hutcheson with that school of thought which found virtue to consist in benevolence, there is equally no doubt that he (Hutcheson) gave a prominent place to self-love:

Our reason can indeed discover certain bounds, within which we may not only act from self-love consistently with the good of the whole; but every mortal's acting thus within these bounds for his own good, is absolutely necessary for the good of the whole; and the want of selflove would be universally pernicious.... But when self-love breaks over the bounds above mentioned, and leads us into actions detrimental to others, and to the whole; or makes us insensible of the generous kind affections; then it appears vicious, and is disapproved.

(Hutcheson 1725: III.v)

As in the case of Smith, what is critically important is man's desire to be approved of:

an high pleasure is felt upon our gaining the approbation and esteem of others for our good actions, and upon their expressing their sentiments of gratitude; and on the other hand, we are cut to the very heart by censure, condemnation, and reproach.

(Hutcheson 1755: 25)

On Hutcheson's argument an important source of control is represented by a capacity for judgement, including moral judgement, which is linked with man's deployment of internal senses such as the 'sympathetic' which differ from external senses such as sight, sound, or taste, and 'by which, when we apprehend the state of others, our hearts naturally have a fellow-feeling with them' (ibid.: 19).

It was Hutcheson's contention that men were inclined to, and fitted for, society: 'their curiosity, communicativeness, desire of action, their sense of honour, their compassion, benevolence, gaiety and the moral faculty, could have little or no exercise in solitude' (ibid.: 34).

This discussion was to lead to Hutcheson's treatment of natural rights and of the state of nature in a manner which is reminiscent of Locke. He also advances the Lockian claim that the state of nature is a state not of 
war but of inconvenience which can be resolved only by the establishment of government in terms of a complex double contract.

This has been described as the 'Real Whig position' (Winch 1978: 46; Robbins 1968) and may explain the considerable influence of Hutcheson's political ideas in the American colonies (Norton 1976). Hutcheson's 'warm love of liberty' was attested by Principal Leechman in his introduction to the System (1755: xxxv-xxxvi); a sentiment which was echoed by Hugh Blair (Winch 1978: 47-8) in a contemporary review of the book.

While agreeing that an essential precondition of social stability is some system of 'magistracy' (Smith 1759: VII.iv.36), Adam Smith (like Hume) was to emerge as a critic of the contract theory. In addition, he criticised Hutcheson for seeming to imply that self-love was 'a principle which could never be virtuous in any degree or in any direction' (ibid.: VII.ii.3.12). But for the economist it is important to note that Hutcheson distinguished often more clearly than did Smith between approval and moral approbation. As Hutcheson put it:

The calm desire of private good, tho' it is not approved as a virtue, yet it is far from being condemned as a vice. And none of the truly natural and selfish appetites are of themselves condemned as evil, when they are within certain bounds, even tho' they are not referred by the agent to any public good. It was necessary for the general good that all such affections should be implanted in our species; and therefore it would have been utterly unnatural to have made them a matter of disapprobation.

(Hutcheson 1755: 65)

Elsewhere he noted that '[a] penetrating genius, capacity for business, patience of application and labour ... are naturally admirable and relished by all observers, but with quite a different feeling from moral approbation' (ibid.: 28).

Whatever the differences of emphasis and of analysis which are disclosed in the writings of Hutcheson and Smith, the arguments reviewed in this section are, or should be, important to the economist for three reasons. First, it appears that social order as a basic precondition of economic activity depends in part upon a capacity for moral judgement. Second, it is alleged that the psychological drives which explain economic activity must be seen in a context broader than the economic. Finally, the argument suggests that all forms of activity are subject to the scrutiny of our fellows.

\section{Economic analysis}

There are five major topics covered in Hutcheson's System, which is generally assumed to follow closely the content of his lecture course as a whole. The economic analysis is not given in the form of a single coherent dis- 
course, but rather woven in the broader treatment of jurisprudence. Perhaps for this reason Hutcheson's work did not attract a great deal of attention from early historians of economic thought. But the situation was transformed as a result of Edwin Cannan's discovery of Smith's Lectures on Jurisprudence. Cannan recalled that:

On April 21, 1895, Mr Charles C. Maconochie, Advocate, whom I then met for the first time, happened to be present when, in course of conversation with the literary editor of the Oxford Magazine, I had occasion to make some comment about Adam Smith. Mr Maconochie immediately said that he possessed a manuscript report of Adam Smith's lectures on jurisprudence, which he regarded as of considerable interest.

(Cannan 1896: xv)

While Cannan's reaction may be imagined, the lectures had the effect of confirming Hutcheson's influence upon his pupil on a broad front, but especially in the area of economic analysis (as distinct from policy). For what Cannan discovered was that the order of a large part of Smith's course and its content corresponded closely with what Hutcheson was believed to have taught. It is this correspondence which served to renew interest in Hutcheson's economics with remarkable speed. Quite apart from Cannan's introduction to the Lectures, the same theme is elaborated in his introduction to the Wealth of Nations (1904). The link had also been noted, following the publication of the Lectures, in the Palgrave Dictionary of Political Economy (1896), and received its most elaborate statement in W. R. Scott's Francis Hutcheson (1900). The most modern treatment of this kind is to be found in W. L. Taylor's influential work Francis Hutcheson and David Hume as Predecessors of Adam Smith (1965).

But Cannan noted something else, namely that it may be that the 'germ of the Wealth of Nations' is to be found in Hutcheson's treatment of value (Cannan 1896: xxvi). It is this topic which forms the central feature of the remainder of the present argument, although it will be convenient to begin with Hutcheson's views on the division of labour, where his influence on Smith may be particularly obvious.

But before we pass on to these subjects, it should be noted that Hutcheson's work on economic topics has its own history. It is evident that he admired the work of his immediate predecessor in the Chair of Moral Philosophy - Gershom Carmichael (1672-1729), and especially his translation of, and commentary on, Samuel Pufendorf. In Hutcheson's address to students in universities the Introduction to Moral Philosophy (1742) is described thus:

The learned will at once discern how much of this compound is taken from the writing of others, from Cicero and Aristotle, and to name no 
other moderns, from Pufendorf's smaller work, De Officio Hominis et Civis Juxta Legem Naturalem, which that worthy and ingenious man the late Professor Gerschom Carmichael of Glasgow, by far the best commentator on that book, has so supplied and corrected that the notes are of much more value than the text.

(Taylor 1965: 25)

Carmichael's influence as a student of ethics and of jurisprudence has been frequently celebrated, notably by Sir William Hamilton, who stated that he may be regarded 'on good grounds, as the true founder of the Scottish school of philosophy' (ibid.: 253). But it is to W. L. Taylor that we are indebted for the reminder that Carmichael (and Pufendorf) may have shaped Hutcheson's economic ideas. Taylor concluded that:

The interesting point for the development of economic thought in all this is the very close parallelism between Pufendorf's De Officio and Hutcheson's Introduction to Moral Philosophy. Each man covered almost exactly the same field... The inescapable conclusion is that Francis Hutcheson took over almost in whole, from Carmichael, the economic ideas of Pufendorf.

(Ibid.: 28-9)

\section{The division of labour}

The key issue for both Pufendorf and Hutcheson arose from the comparison of man's situation as an isolated creature and as a member of society. As Pufendorf put it, the situation of the isolated individual:

would seem to have been more wretched than that of any wild beast, if we take into account with what weakness man goes forth into this world, to perish at once, but for the help of others; and how rude a life each would lead, if he had nothing more than what he owed to his own strength and ingenuity. On the contrary, it is altogether due to the aid of other men, that out of such feebleness, we have been able to grow up, that we now enjoy untold comforts, and that we improve mind and body for our own advantage and that of others. And in this sense the natural state is opposed to a life improved by the industry of men.

(Pufendorf 1682: ii, 89)

This broad line of argument was developed in the System (Hutcheson 1755: Book 2, ch. 4) where Hutcheson offered two specific economic applications. First, he noted that the joint labours of twenty men will cultivate forests, or drain marshes, for farms to each one, and provide houses for habitation, and inclosures for their stocks, much sooner than the 
separate labours of the same number' (ibid.: 289). Second, Hutcheson drew attention to the importance of the division of labour.

Nay 'tis well known that the produce of the labours of any given number, twenty, for instance, in providing the necessaries or conveniences of life, shall be much greater by assigning to one, a certain sort of work of one kind, in which he will soon acquire skill and dexterity, and to another assigning work of a different kind, than if each one of the twenty were obliged to employ himself, by turns in all the different sorts of labour requisite for his subsistence, without sufficient dexterity in any. In the former method each procures a great quantity of goods of one kind, and can exchange a part of it for such goods obtained by the labours of others as he shall stand in need of. One grows expert in tillage, another in pasture and breeding cattle, a third in masonry, a fourth in the chase, a fifth in iron-works, a sixth in the arts of the loom, and so on throughout the rest. Thus all are supplied by means of barter with the works of complete artists. In the other method scarce any one could be dextrous and skilful in any one sort of labour.

(Ibid.: 288-9)

\section{Property}

The discussion of the division of labour implies that members of society are interdependent in respect of the satisfaction of their wants and also led to two further analytical developments: security of property and the problem of value in exchange (see, especially, Brown 1987).

Much of the discussion in Book 2, ch. 6, of the System is concerned with 'the right of property'. But Hutcheson also noted that:

If we extend our views further and consider what the common interest of society may require, we shall find the right of property further confirmed. Universal industry is plainly necessary for the support of mankind. Tho' men are naturally active, yet their activity would rather turn towards the lighter and pleasanter exercises, than the slow, constant, and intense labours requisite to procure the necessaries and conveniences of life, unless strong motives are presented to engage them to these severer labours. Whatever institution therefore shall be found necessary to promote universal diligence and patience, and make labour agreeable or eligible to mankind, must also tend to the public good; and institutions or practices which discourage industry must be pernicious to mankind. Now nothing can so effectually excite men to constant patience and diligence in all sorts of useful industry, as the hopes of future wealth, ease, and pleasure to themselves, their offspring, and all who are dear to them, and of some honour too to 
themselves on account of their ingenuity, and activity, and liberality. All these hopes are presented to men by securing to every one the fruits of his own labours, that he may enjoy them, and dispose of them as he pleases...

Nay the most extensive affections could scarce engage a wise man to industry, if no property ensued upon it.

(Ibid.: 320-1)

Hutcheson attached a great deal of importance to freedom of choice and in fact concluded this phase of the argument by rejecting any suggestion that 'magistrates' may be involved - passages which may well have attracted the attention of the youthful Smith (ibid.: 322-3).

\section{The theory of value}

It is Hutcheson's treatment of value which shows most clearly the influence of Pufendorf and of Carmichael where the latter observed that:

In general we may say that the value of goods depends upon these two elements, their scarcity, and the difficulty of acquiring them.... Furthermore, scarcity is to be regarded as combining two elements, the number of those demanding, and the usefulness thought to adhere in the good or service, and which can add to the utility of human life.

(Quoted in Taylor, 1965: 65, emphasis in original; cf. Naldi 1993)

Pufendorf's analysis received its most elaborate statement in the De Jure, in the long chapter 'On Price' (Book 5, ch. 1). The most succinct statement, on which Carmichael commented, is to be found in the De Officio, where Pufendorf observed:

Of common value the foundation as such is that aptitude of the thing or service, by which it can contribute something directly or indirectly to the necessities of human life, and to make it more comfortable or agreeable. Hence we usually call things that serve no use at all things of no value. Yet there are some things most useful for human life, upon which no definite value is understood to have been set, either because they do not admit of ownership, and necessarily so, or because they are unsuited for exchange, and hence withdrawn from trade, or because in trade they are never considered otherwise than as an addition to something else (e.g. the ether, the heavenly bodies, the ocean, sunlight, clear, pure air, the fair face of the earth, the wind and shade).... For in this matter the necessity of the thing, or its exalted usefulness, are so far from always holding the first place, that we rather see men hold in lowest esteem the things with which human 
life cannot dispense. And this because nature, not without the singular providence of God, pours fourth a bountiful supply of them. Hence an increase of value tends to be produced especially by scarcity. . . . For articles in everyday use prices are raised especially when their scarcity is combined with necessity or want.

(Pufendorf 1682: Book 1, ch. 14: 70-3, emphasis in original)

To this Pufendorf added two important points which relate to what may be termed the supply price and to associated matters affecting the rate of exchange.

In the case of artificial commodities, scarcity apart, the price is chiefly raised by the fineness and elegance of the workmanship which they display, sometimes too by the fame of the artificer, also the difficulty of the work, the scarcity of artisans and workmen, and so forth. As for services and acts, difficulty enhances their price, as do also skill, utility, necessity, the scarcity or rank or freedom of the agents, and finally even the reputation of the art, as being accounted noble or ignoble. The opposite of these things usually lowers the price.

(Ibid.: 71; cf. Pufendorf 1688: Book 5, ch. 1)

Second, Pufendorf seems to have distinguished between the utility of the commodity to be acquired in exchange and our perception of the value of the good to be exchanged:

[A]s a rule, people who possess a thing do not set the same value on it as people who wish to acquire it, since we have always looked upon the thing which we call our own and which we give away, as being exceedingly valuable. Nevertheless, the amount of the exchange, must be regulated by the value which the recipient sets upon the gifts received.

(Ibid.: Book 5, ch. 1, para. 9)

In a passage which suggests a distinction between the utility expected and that which is realised, he argued with regard to the estimation of the value of a commodity by an individual that "perhaps it ought not to be fixed at the value which he sets upon it when it is in his hand, but at the value which he set upon it before he had it' (ibid.: Book 5, ch. 1, para. 9).

Hutcheson in effect opened his analysis of the problem by pointing out that the "natural ground of all value or price is some sort of use which goods afford in life', adding that 'by the use causing a demand we mean not only a natural subserviency to our support, or to some natural pleasure, but any tendency to give any satisfaction, by prevailing custom or fancy, as a matter of ornament or distinction' (Hutcheson 1755: II, 53-4). He continued: 
But when some aptitude to human use is presupposed, we shall find that the prices of goods depend on these two jointly, the demand on account of some use or other which many desire, and the difficulty of acquiring, or cultivating for human use. When goods are equal in these respects men are willing to interchange them with each other; nor can any artifice or policy make the values of goods depend on any thing else. When there is no demand, there is no price, were the diffculty of acquiring never so great: and where there is no difficulty or labour requisite to acquire, the most universal demand will not cause a price; as we see in fresh water in these climates. Where the demand for two sorts of goods is equal, the prices are as the difficulty. Where the difficulty is equal, the prices are as the demand.

(Ibid.: II, 54, emphasis in original)

Hutcheson then added two points which are reminiscent of Pufendorf in commenting on issues which affect supply price and the rate of exchange. First, he argued:

In like manner by difficulty of acquiring, we do not only mean great labour or toil, but all other circumstances which prevent a great plenty of the goods or performances demanded. Thus the price is encreased by the rarity or scarcity of the materials in nature, or such accidents as prevent plentiful crops or certain fruits of the earth; and the great ingenuity and nice taste requisite in the artists to finish well some works of art, as men of such genius are rare. The value is also raised, by the dignity of station in which, according to the custom of the country, the men must live who provide us with certain goods, or works of art. Fewer can be supported in such stations than in the meaner; and the dignity and expense of their stations must be supported by the higher prices of their goods or services. Some other singular considerations may exceedingly heighten the values of goods to some men, which will not affect their estimation with others. These above mentioned are the chief which obtain in commerce.

(Ibid.: II, 54-5)

As regards the rate of exchange, Hutcheson commented:

In commerce it must often happen that one may need such goods of mine as yield a great and lasting use in life, and have cost a long course of labour to acquire and cultivate, while yet he has none of those goods I want in exchange, or no sufficient quantities; or what goods of his I want, may be such a yield but a small use, and are procurable by little labour. In such cases it cannot be expected that I should exchange with him.... I must search for others who have the goods I want, and such quantities of them as are equivalent in use to 
my goods, and require as much labour to produce them; and the goods on both sides must be brought to some estimation or value.

(Ibid.: II, 53)

But although these positions do not differ significantly from Pufendorf, Hutcheson does seem to have taken notice of two additional points. First, he seems to suggest, as the above quotation indicates, that goods will exchange at a rate which will be in part determined by the quantity of labour embodied in them (a point later taken up by Smith). Second, he noted in a passage which may have been 'foreshadowed' by Pufendorf that some commodities:

of great use have no price, either because they are naturally destined for community, or cannot come into commerce but as appendages of something else, the price of which may be increased by them, though they cannot be separately estimated.

(Hutcheson 1742: 200; quoted by Taylor 1965: 66)

\section{Money}

The discussion of value in exchange led Hutcheson on quite logically to consider the medium of exchange, namely money, and here too he followed an old tradition which had already been commented upon by Pufendorf. In the De Officio (Book 1, ch. 14) he noted the inconvenience of exchange by barter:

But after men departed from their primitive simplicity and various kinds of gain were introduced, it was readily understood that common value alone was not sufficient for the transactions of men's affairs and their increased dealings...

Hence most nations, attracted by a richer mode of life, have seen fit by convention to impose a value par excellence upon a certain thing, in order that the common values of other things might be tested by this, and virtually contained in the same; so that by this medium one could acquire anything that is for sale, and engage conveniently in any sort of dealings and contracts.

(Pufendorf 1682: 72-3)

He added:

$[F]$ or this purpose most nations have decided to employ the nobler and rarer metals. For they possess a very compact substance, so as not to be worn away easily in use, and also they admit of division into many small pieces. And they are no less convenient to keep and to 
handle, while on account of their rarity, they can equal the value of many other things.

(Ibid.: 73)

Similar points are made in the De Jure (Book 5, ch. 1) where Pufendorf elaborated on the need for coinage and the problems of debasement. These passages are interesting not least for the emphasis given to the need for a stable value, and evidence of a search for an invariable standard of value of the kind that money alone could not provide, at least over a long term of years.

Once more, Hutcheson followed suit in explaining the problems of barter and the need to establish a standard or 'common measure' when settling the 'values or goods for commerce' (Hutcheson 1755: 55):

The qualities requisite to the most perfect standard are these: it must be something generally desired so that men are generally willing to take it in exchange. The very making any goods the standard will of itself give them this quality. It must be portable; which will often be the case if it is rare, so that small quantities are of great value. It must be divisible without loss into small parts, so as to be suited to the values of all sorts of goods; and it must be durable, not easily wearing by use, or perishing in its nature. One or other of these prerequisites in the standard, shews the inconvenience of many of our commonest goods for that purpose. The man who wants a small quantity of my corn will not give me a work-beast for it, and his beast does not admit division. I want perhaps a pair of shoes, but my ox is of far greater value, and the other may not need him. I must travel to distant lands, my grain cannot be carried along for my support, without unsufferable expense, and my wine would perish in the carriage. 'Tis plain therefore that when men found any use for the rarer metals, silver and gold, in ornaments and utensils, and thus a demand was raised for them, they would soon also see that they were the fittest standards for commerce, on all the accounts above-mentioned.

(Ibid.: II, 55-6)

The familiar arguments concerning the need for coinage and the dangers of debasement follow (ibid.: Book 2, ch. 12) while there is also a hint of the need to find an invariable measure of value at least over long periods of time:

We say indeed commonly, that the rates of labour and goods have risen since these metals grew plenty; and that the rates of labour and goods were low when the metals were scarce; conceiving the value of the metals as invariable, because the legal names of the pieces, the pounds, shillings, or pence, continue to them always the same till a law 
alters them. But a day's digging or ploughing was as uneasy to a man a thousand years ago as it is now, tho' he could not then get so much silver for it: and a barrel of wheat, or beef, was then of the same use to support the human body, as it is now when it is exchanged for four times as much silver. Properly, the value of labour, grain, and cattle, are always pretty much the same, as they afford the same uses in life, where no new inventions of tillage, or pasturage, cause a greater quantity in proportion to the demand. 'Tis the metal chiefly that has undergone the great change of value, since these metals have been in greater plenty, the value of the coin is altered tho' it keeps the old names.

(Ibid.: II, 58)

\section{Adam Smith}

Edwin Cannan, as we have seen, considered that Hutcheson's emphasis on the utility of the goods to be acquired and on the disutility of effort needed to create the goods to be exchanged, with the attendant emphasis on demand and supply-side considerations, provided the 'kernel' of the Wealth of Nations (cf. Skinner 1996: 146-8). Taylor, on the other hand, suggested that Smith's concern with material welfare (1965: 193) served to obscure the line of argument set out by Hutcheson.

Robertson and Taylor in fact concluded that:

It is evident that the magnum opus [the Wealth of Nations] was cast in a mould of a powerful unifying conception. Now within this framework it is evident that the measurement, in real terms, of the wealth of nations, and in particular of its progress, would seem to call for some unvarying standard of value which would enable valid comparisons to be made through time ... for this reason, if for no other, it does not appear inexplicable that Adam Smith no longer paid so much attention to the lines of argument taken over from Hutcheson, which had served well enough in the Lectures.

(Robertson and Taylor 1957: 194-5)

What Robertson and Taylor did not note was that Smith's preoccupation with a real measure of value may also have owed much to Hutcheson (cf. Skinner, 1966: 148-50). Nor, apparently, did they appreciate that Smith's treatment of value in exchange was consistent with his main interest, namely in the measurement of economic welfare as it involves exchange.

The word value, it is observed, has two different meanings, and sometimes expresses the utility of some particular object, and sometimes the power of purchasing other goods which the possession of that object conveys.

(Smith 1776: I.iv.13, emphasis in original) 
The first problem concerns the forces which determine the rate at which one good, or units of one good, may be exchanged for another; the second is concerned basically with the means by which we can measure the value of the total stock of goods created by an individual, and which is used in exchange for others.

As regards the rate of exchange, Smith isolated two relevant factors: the usefulness of the good to be acquired, and the 'cost' incurred in creating the commodity to be given up. The first of the relevant relationships is obviously that which exists between 'usefulness' and value. The elements of Smith's argument become apparent in his handling of the famous paradox, namely that:

The things which have the greatest value in use have frequently little or no value in exchange; and, on the contrary, those which have the greatest value in exchange have frequently little or no value in use. Nothing is more useful than water: but it will scarce purchase anything. A diamond, on the contrary, has scarce any value in use; but a very great quantity of other goods may frequently be had in exchange for it.

(Ibid.: I.iv.13)

The solution to this paradox can be stated in two stages, where the first involves an explanation as to why two such goods have some value, and the second an explanation as to why the two goods have different values.

Smith's handling of the first part of the problem is based on his recognition of the fact that both goods are considered to be 'useful' although noting that the 'utilities' of each are qualitatively different. In the former case (water) we place a value on the good because we can use it in a practical way, while in the latter (diamonds) we place a value on the good because it appeals to our 'senses', an appeal which, as Smith observed, constitutes a ground 'of preference', or 'source of pleasure'. He concluded: 'The demand for the previous stones arises altogether from their beauty. They are of no use but as ornaments' (ibid.: I.xi.c.32). The utilities of the two goods thus emerge as being qualitatively different, although the significant point is seen to be that both have some value precisely because they represent sources of satisfaction to the individual.

Smith was then left with the second part of the initial problem, namely the explanation as to why the two goods have different values. Here again, the answer provided, while simple, is clear, embodying the argument that merit (value) is a function of scarcity. As Smith put it, "the merit of an object which is in any degree useful or beautiful, is greatly enhanced by its scarcity' (ibid.: I.xi.c.31). Even more specifically he remarked:

Cheapness is in fact the same thing with plenty. It is only on account of the plenty of water that it is so cheap as to be got for the lifting, and 
on account of the scarcity of diamonds (for their real use seems not yet to be discovered) that they are so dear.

(Smith 1978: LJ (B): 487)

Smith introduced the second major element in the problem by observing that the rate at which the individual will exchange one good for another must be affected not only by the utility of the good to be acquired, but also by the 'toil and trouble' involved in creating the good exchanged. In this connection he recognised that in acquiring the means of exchange (goods in the barter case), the individual must undergo the 'fatigues' of labour and thus 'lay down' a 'portion of his ease, his liberty, and his happiness' (Smith 1776: I.v.7).

But, in dealing with the rate of exchange, Smith may be seen to have placed most emphasis on the supply side of the problem, and explicitly argued that in the case of the barter economy 'the proportion between the quantities of labour necessary for acquiring different objects seems to be the only circumstance which can afford any rule for exchanging them for one another (ibid.: I.vi.1). This is one way of looking at the problem of exchange value, which clearly shows a parallel with Hutcheson. But Smith seems to have treated it, not as an end in itself, but as a means of elucidating those factors which govern the value of the whole stock of goods which the individual creates, and which he proposes to use in exchange.

Looking at the problem in this way, Smith went on to argue that:

The value of any commodity ... to the person who possesses it, and who means not to use or consume it himself, but to exchange it for other commodities, is equal to the quantity of labour which it enables him to purchase or command. Labour, therefore, is the real measure of the exchangeable value of all commodities.

(Ibid.: I.v.1)

Smith's meaning becomes clear when he remarks that the value of a stock of goods must always be in proportion to:

the quantity ... of other men's labour, or what is the same thing, of the product of other men's labour, which it enables him to purchase or command. The exchangeable value of every thing must always be precisely equal to the extent of this power.

(Ibid.: I.v.3; emphasis added)

In other words, Smith is here arguing that the real value of the goods which the workman has to dispose of (in effect his income) must be measured by the quantity of goods (expressed in terms of labour units) which he can command, and which he receives once the whole volume of (separate) exchanges has taken place. 
As Smith observed, a clear difference between the barter and modern economies is to be found in the fact that while, in the former, goods are exchanged for goods, in the latter, goods are exchanged for a sum of money, which may then be expended in purchasing other goods. Under such circumstances the individual, as Smith saw, very naturally estimates the value of his receipts (received in return for undergoing the 'fatigues' of labour) in terms of money, rather than in terms of the quantity of goods he can acquire by virtue of his expenditure. However, Smith was at some pains to insist that the real measure of welfare (that is, our ability to satisfy our wants) was to be found in 'the money's worth' rather than the money, where the former is determined by the quantity of products (labour 'commanded') which either individuals or groups can purchase. On this basis, Smith went on to distinguish between the nominal and the real value of income, pointing out that if the three original sources of (monetary) revenue in modern times are wages, rent, and profit, then the real value of each must ultimately be measured 'by the quantity of labour which they can, each of them, purchase or command' (ibid.: I.vi.9).

This argument has endeavoured to establish that, while Hutcheson owed much to Pufendorf, so too did Adam Smith. The link between their treatments of exchange value is palpable, even if Smith gave more emphasis to the measurement of economic welfare than he did to the issue of value in exchange. But there is another intriguing contrast and parallel.

Readers of the Wealth of Nations and the Theory of Moral Sentiments will need no reminding that Smith did not conceive of welfare as measurable in real terms alone. In Smith's view happiness is a state of mind and he was well aware of the social and psychological costs of economic growth (ibid.: V.I.f.60). Indeed, it is this perspective which returns us to the form of argument stated in the opening section where it was noted that both Hutcheson and Smith emphasised that men desire to be approved of and that this approval is itself a source of satisfaction. Smith argued in effect that the pursuit of gratification is not inconsistent with propriety - and indeed should be consistent with it. Again Hutcheson concurred:

there is no necessary vice in the consuming of the finest products, or the wearing of the dearest manufactures by persons whose fortunes can allow it consistently with all the duties of life. But what if men grew generally more frugal and abstemious in such things? More of these finer goods could be sent abroad.

(Hutcheson 1755: II, 320; cf. Taylor 1965: ch. 4)

A mercantilist to the last? 


\section{Conclusion}

This chapter has pursued two themes. First, we have endeavoured to establish Hutcheson's link with Pufendorf in a manner which confirms a debt to the work of W. L. Taylor. Second, the argument has sought to give prominence to the role of subjective judgement as regards the determinants of value in the works of both Pufendorf and Hutcheson.

But the argument also sheds some light on Adam Smith. The discovery of Smith's Lectures in 1895 (1896) enabled Cannan and others to establish the content of Smith's teaching in 1763 and thus assess his debts to the French economists (cf. Skinner 1996: ch. 6). Equally important is the fact that the content of the Lectures exposed Smith's debt to Hutcheson, both with regard to the order of the argument, and with reference to Smith's treatment of value.

At one time it was assumed that Smith had stated, but did not solve, the famous paradox of value; an illusion dispelled not only by the Lectures, but also, as we have seen, by the Wealth of Nations itself. Smith paid attention to the issues of utility expected, which was always likely to change in the estimation of the consumer, but also to the phenomenon of disutility incurred in creating commodities to be used in exchange and which was assumed to be constant - both arguments are to be found in Hutcheson.

But as we have seen there is a change in focus in the Wealth of Nations which led Smith to state a version of the labour (embodied) theory of value; a doctrine now associated with David Ricardo, but also to be found in the teaching of his master. The labour-embodied theory of value led on to the doctrine of labour commanded as a measure of the real value of income; the pursuit of a measure of real value once again illustrating one of Hutcheson's concerns (cf. Skinner 1996: ch. 7).

\section{Note}

1 This chapter formed the basis of a lecture delivered at a conference held in Glasgow to celebrate the tricentenary of the birth of Francis Hutcheson (1694-1746), the second incumbent of the Chair of Moral Philosophy in the University of Glasgow. The purpose of the present argument is to convey something of the flavour of Hutcheson's teaching in economics and to confirm his debt to one of his teachers, Gerschom Carmichael (1672-1729), his predecessor in the philosophy Chair, and, through Carmichael, a further debt to Pufendorf. The chapter is a revised version of Andrew S. Skinner, 'Pufendorf, Hutcheson and Adam Smith', Scottish Journal of Political Economy 42 (1995), by permission of Blackwell Publishing. This article also appeared in a different modified form in Skinner (1996).

\section{References}

Brown, V. (1987) 'Value and Property in the History of Economic Thought: an Analysis of the Emergence of Scarcity', Oekonomia 7. 
Campbell, T. D. (1982) 'Francis Hutcheson', in R. H. Campbell and A. S. Skinner (eds), The Origins and Nature of the Scottish Enlightenment, Edinburgh: John Donald.

Cannan, E. (1896) Adam Smith's Lectures on Justice, Police, Revenue and Arms, Oxford: Clarendon Press.

— ([1904] 1930) 'Introduction' to A. Smith, An Inquiry into the Nature and Causes of the Wealth of Nations, edited by E. Cannan, London: Methuen.

Hutcheson, Francis (1725) Inquiry into the Original of our Ideas of Beauty and Virtue, London; 2nd edn, 1776.

— (1742) Philosophie Moralis Institutio Compendiaria, Ethics et Jurisprudentiae Naturalis Elementa continens, Libri Tres; 2nd edn, 1745; published as A Short Introduction to Moral Philosophy in Three Books, containing the Elements of Ethics and the Law of Nature, Glasgow, 1747.

(1755) A System of Moral Philosophy in Three Books, written by the late Francis Hutcheson, LL D, Professor of Moral Philosophy in the University of Glasgow. Published from the original MS by his son Francis Hutcheson, MD to which is prefixed Some Account of the Life, Writings, and Character of the Author, by The Reverend William Leechman, DD, Professor of Divinity in the same University, Glasgow.

Hutchison, T. (1988) Before Adam Smith: The Emergence of Political Economy, 16621776, Oxford: Blackwell.

McCosh, J. (1875) The Scottish Philosophy from Hutcheson to Hamilton, London: Macmillan.

Meek, R. L. (1976) 'New Light on Adam Smith's Lectures on Jurisprudence', History of Political Economy 8.

Naldi, N. (1993) 'Gershom Carmichael on Demand and Difficulty of Acquiring', Scottish Journal of Political Economy 40.

Norton, D. F. (1976) 'Francis Hutcheson in America', in T. Besterman (ed.), Studies on Voltaire and the Eighteenth Century CLIV.

Palgrave, R. H. I. (ed.) (1896) Dictionary of Political Economy, London.

Pesciarelli, E. (1986) 'On Adam Smith's Lectures on Jurisprudence', Scottish Journal of Political Economy 33.

Pufendorf, Samuel von ([1682] 1927) De Officio et Civis Juxta Legem Naturalem Libri Duo, Classics of International Law series, translated by Frank Gardiner Moore, Oxford.

— ([1688] 1934) De Jure Naturae et Gentium Libri Octo, Classics of International Law series, translated by C. H. and W. A. Oldfather, Oxford.

Robbins, C. (1954) 'When is it that Colonies may turn Independent: an Analysis of the Environment and Politics of Francis Hutcheson', William and Mary Quarterly 11.

— (1968) The Eighteenth-Century Commonwealth Man, New York: Atheneum.

Robertson, H. M. and Taylor, W.L. (1957) 'Adam Smith's Approach to the Theory of Value', Economic Journal 67.

Scott, W. R. (1900) Francis Hutcheson, his Life, Teaching and Position in the History of Philosophy, Cambridge: Cambridge University Press.

— (1932) 'Francis Hutcheson', in E. R. A. Seligman (ed.), Encyclopaedia of the Social Sciences 7.

Skinner, A. S. (1987) 'Frances Hutcheson', in J. Eatwell, M. Milgate and P. Newman (eds), The New Palgrave: A Dictionary of Economics, London: Macmillan. 
(1996) A System of Social Science: Papers relating to Adam Smith, 2nd edn Oxford: Clarendon Press.

Smith, Adam ([1759] 1976) The Theory of Moral Sentiments, edited by D. D. Raphael and A. L. Macfie, Oxford: Clarendon Press.

([1776] 1979) An Inquiry into the Nature and Causes of the Wealth of Nations, edited by R. H. Campbell, A. S. Skinner and W. B. Todd, Oxford: Clarendon Press.

- (1977) The Correspondence of Adam Smith, edited by E. Mossner and I. S. Ross, Oxford: Oxford University Press.

(1978) Lectures on Jurisprudence, edited by R. L. Meek, D. D. Raphael and P. G. Stein, Oxford: Clarendon Press.

Taylor, W. L. (1965) Francis Hutcheson and David Hume as Predecessors of Adam Smith, Durham NC: Duke University Press.

Winch, D. (1978) Adam Smith's Politics: An Essay in Historiographic Revision, Cambridge: Cambridge University Press.

Young, J. (1997) Economics as a Moral Science: The Political Economy of Adam Smith, Cheltenham: Edward Elgar. 


\title{
4 David Hume as a political economist
}

\author{
Carl Wennerlind
}

\section{Brief biographical details}

David Hume (1711-76) was born in Edinburgh and grew up on the family estate, Ninewells, near Berwick in the lowlands. He studied at the University of Edinburgh. ${ }^{1}$ At the age of twenty-three, he left Scotland for Bristol, where he attached himself to a merchant in order to learn about the world of commerce. After a brief attempt at a merchant's career, Hume spent three years in France, during which he worked on his first book, $A$ Treatise of Human Nature (1739-40). Having seen to the publication of his book in London, he returned to Scotland and turned his attention to essay writing, publishing Essays and Treatises on Several Subjects (1741-42). Denied a professorship at the University of Edinburgh, he authored the Enquiry Concerning Human Understanding (1748) and the Enquiry Concerning the Principles of Morals (1751). A couple of years later he added another section, The Political Discourses (1752), to his book of essays, now titled Essays Moral, Political, and Literary. Failing once again to obtain a university professorship, Hume was appointed librarian of the Advocates' Library, which enabled him to research his next major project, the six-volume History of England (1754-62). Following publication of the last volume of this work, Hume served as secretary to the British ambassador in Paris. In this post he quickly gained notoriety among the French intelligentsia. In 1768, after a brief period in London, where he served as under-secretary of state, he returned to Edinburgh, where he lived until his death in 1776.

\section{Introduction}

David Hume wrote about political economy in order to encourage debate about the best way to secure virtue and prosperity in a rapidly modernising commercial world. From the time of his first publication, A Treatise of Human Nature, in which he articulated his thoughts on how a society and its polity should be organised to reap the greatest benefits from commerce, he engaged in a lifelong effort to advise citizens and legislators on how to respond to political and economic concerns. Hume was motivated 
by a desire to influence public opinion and ultimately to have an impact on how society was governed. For Hume, as it was for Adam Smith, political economy was fundamentally a science of the legislator. He joined a debate about politics and commerce that had its most immediate roots in the vibrant pamphleteering that emerged in Scotland and England around the turn of the eighteenth century as a result of the period's political turmoil and economic transformations. He also entered an overlapping, more abstract debate about political philosophy and political economy, addressing the ideas of such thinkers as John Locke, Lord Bolingbroke, John Law, George Berkeley, Francis Hutcheson and Baron de Montesquieu. Posterity, for the most part, has viewed Hume as primarily engaging with these authors over more theoretical issues; however, the current historiographical trend is to argue that, although Hume learned and absorbed ideas from his philosophical predecessors and peers, he wrote for a more general, educated audience on issues with immediate practical implications. ${ }^{2}$ That is, the mid-eighteenth-century debates over British political and economic policy may provide the most important context for understanding Hume's thought - more important than timeless discussions about abstract principles. ${ }^{3}$

After his failed attempt to gain a public voice through his ambitious youthful philosophical writings in the Treatise, Hume turned to a different medium, through which he would experience great success and universal acclaim: the essay. Influenced by Addison and Steele (The Spectator and Tatler), Bolingbroke (The Craftsman), and Trenchard and Gordon (Cato's Letter), Hume set out to provide his own version of the eighteenth-century genre of polite moral and political commentary. In the essay Of EssayWriting, Hume reflects on his role as 'an Ambassador from the Dominions of Learning to those of Conversation' (Hume 1742: 535). He sees himself as providing 'Intelligence to the Learned of whatever passes in Company, and ... endeavour[ing] to import into Company whatever Commodities I find in my native Country proper for their Use and Entertainment.' He continues to describe this exchange in the vernacular of political economy:

The Balance of Trade we need not be jealous of, nor will there be any Difficulty to preserve it on both sides. The Materials of this Commerce must chiefly be furnish'd by Conversation and common Life: The manufacturing of them alone belongs to Learning.

(Ibid.)

While leaving the treatise writing behind, he retained the political and philosophical vision he formulated in the 1730s and applied it in his later writings on politics, culture, economics, and history. There is consequently a discernible theoretical core forming the basic parameters of his Essays Moral, Political, and Literary, the two Enquiries, and his History of England. ${ }^{4}$ 
Hume was interested in a broad set of contemporary societal issues, some of which were relevant to the wider European context, while others were of more local concern. It is not always easy to recognise what social or geographical context Hume had in mind, or if he even had one, as he phrased most of his discussions in general terms. ${ }^{5}$ When he chose to exemplify his discussion he opted to refer to examples from the ancient world rather than the specific context he perhaps had in mind. This rhetorical strategy may have been motivated by a concern to make his interventions applicable as widely as possible or, alternatively, to obfuscate that he really intended his policy prescriptions to apply to a particular local context, perhaps to that of Scotland or, even more specifically, to the Scottish Highlands. There is validity to both of these speculations. Hume wrote on a number of different issues, some of which were quite clearly related to the pressing need to civilise the Highlands, while others had greater applicability to Scotland's position in Britain, to Britain's position vis-à-vis Europe, and to Europe's role in the world. Whether he was writing about general or specific issues, his analyses and prescriptions centred on a coherent set of ideas. It is this analytical core that I seek to frame in this chapter.

The present chapter outlines the issues that most concerned Hume as a political economist, in terms of both his vision of society as a whole and his more policy-oriented interests. ${ }^{6}$ Hume's governing vision of society was informed by the belief that commercial modernisation was not only capable of bringing about material prosperity, but also had the capacity to civilise and refine people and their society. In many ways, his vision resembles the invisible-hand notion, which holds that if people are given personal liberty they will act in ways that unintentionally tend to enhance public welfare. However, Hume's discussion of the causalities, or rather the constant conjunctures, at work in this chain of events escapes economic reductionism by focusing on a broad set of moral, political, and economic considerations. While Hume followed Mandeville in accepting the proposition that people are principally driven by their own rather narrow self-interest, ${ }^{7}$ he argued that a number of specific conditions must be met for self-regarding actions to translate into social, political, and cultural improvements. First, society must be structured within a particular institutional framework (the first part of this chapter). Second, people should dedicate their energies to industry, commerce, and the arts (the second part). Additionally, a constitutional form conducive to the development of a commercial society needs to be established (the third part). Once he had outlined the ideal institutional and constitutional forms and the appropriate behavioural norms, Hume turned his focus to more detailed policy questions. First, he dealt with the issue of international commerce (the fourth part) and then he discussed the nature and dynamics of money, public credit, and interest rates (the fifth part). 


\section{Institutional form}

In order for mankind to be able to achieve a higher degree of civilisation, a more prosperous economy, and a liberal polity, Hume held that the proper social form had to be established. ${ }^{8}$ In the absence of a Hutchesonian moral sense, a feasible Lockean contract, or a Harringtonian civic humanist disposition, people had to find some other way to curb their avidity enough to allow peaceful societal coexistence. Hume was realistically pessimistic about the prospects of people tempering their avarice in ways that would allow them to behave in mutually serviceable ways. ${ }^{9}$ The only solution he thought feasible was a mechanism that would redirect people's avidity and thus transform the maintenance of justice into an unintended consequence of the pursuit of people's long-term self-interest. The crucial challenge of this solution was to ensure that people would prioritise their long-term welfare over their immediate gratification.

Hume developed his notion of justice in the context of commercial relations. He described how people form conventions that help them redirect their self-interest so that they abstain from each others' possessions, carry out exchanges in an honest manner, and honour contractual promises forged in the market place. While such virtuous behaviour does not entail any significant sacrifices when performed among family and close friends, it requires greater restraint among strangers. After all, respecting the property of others and honouring debts to strangers are not necessarily in a person's narrowly defined self-interest. However, Hume believed that people would realise by trial and error that it is actually in their own interest to abide by the rules of property, markets, and money. Once enough people recognise the benefits of participating in these conventions and realise that unco-operative behaviour will eventually hurt them by denying their access to the conventions, they will form a society based on virtuous and just commercial relations. Hence, the conventions of property, markets, and money provide the basic structural foundation on which a prosperous, liberal, and civilised modernity can develop. ${ }^{10}$

While Hume believed that the conventions are formed organically by people pursuing their own long-term interests, without the active guidance of the government, he did recognise the need for the government to protect the conventions against transgressors. Although violations of the conventions are unlikely,

[t]hey are, however, never the less real for being remote; and as all men are, in some degree, subject to the same weakness, it necessarily happens, that the violations of equity must become very frequent in society, and the commerce of men, by that means, be render'd very dangerous and uncertain. 
The possibility that people will fall victim to their immediate inclinations necessitates that the state assumes a protective role. This role, however, is rather limited and excludes more ambitious attempts at social engineering that require the transformation of 'the common bent of mankind' (Hume 1752: 260).

\section{Industry, commerce, and the arts}

According to Hume, in order to shape a civilised society, it was not sufficient for people just to uphold property, markets, and money. Something else was required. The civic republican tradition had relied on a commitment to the public good to ensure that people contributed to the improvement of society. Addison and Steele emphasised the possibility of transforming people's manners by exposing them to instructional journalism, hoping it would shape the coffee-house conversations, as well as the discourse in the greater public sphere. ${ }^{11}$ Hume was not satisfied with either of these solutions. He found civic humanism out of touch with the actualities of humanity and, despite being sympathetic to the politeness project, he found the Addisonian solution incapable of orchestrating a fundamental cultural transformation. For Hume, a stronger transformational force was necessary: something that could change people's conduct in ways that simultaneously transform society, culture, economy, and polity. His answer was the cultivation of industry, commerce, and the arts.

Industry - systematic, methodical, and sustained labour - played a central role in the civilising process in numerous ways. Not only was it the very foundation of riches, power, and economic growth, it was also the basis of a new social discipline. This dual role of labour as wealth producer and mechanism for social control dates back to the seventeenth century, when political thinkers were responding to the threat of social anarchy associated with landless vagrants, sturdy beggars, and idle rogues. While the immediate solution to this so-called employment problem was to minimise social unrest by feeding and housing the surplus population, the more enduring challenge was to eliminate it altogether by transporting the unproductive population to the colonies, disciplining them through the Bloody Code, or finding ways to harness their potential by putting them to work. Hume emphasised the latter solution. He believed that, when people are busy working, not only are they supporting themselves and contributing to the nation's wealth, but, since their time is occupied and most of their energy absorbed, they have little of either for disruption, rebellion, and debauchery. Furthermore, since each employed person is constantly supervised by an employer, the worker is under a certain level of discipline at all times. As part of their duties, workers learn respect for authority and the importance of punctuality, and become accustomed to organising their lives around industry. Hence, labour 
serves as a decentralised device for social control, ensuring that people are co-ordinated and organised in ways that allow a stable social order. ${ }^{12}$

Hume was concerned not only with how labour contributes to the wealth and order of society, but with how the experience of work benefits the individual. He sought to rehabilitate the idea of work from its biblical association with the curse on Adam, and attempted to valorise it as an intrinsically rewarding activity. Hume suggested that the process of labouring brings rewards that extend beyond the wage earned and are separate from any benefits associated with a Protestant work ethic. He argued that people derive actual pleasure from employment and that it provides meaning to their lives. In this sense he echoes the celebration of industry that Puritan writers like Daniel Defoe had earlier put forth. Both Robinson Crusoe (1719) and Moll Flanders (1722) represent the idea that productive and systematic labour is the only real sustainable source of happiness. Only when his protagonists are engaged in industrious pursuits do they succeed in staying away from socially and intellectually destructive habits and manage to live virtuous lives. Defoe describes the joys of diligence, creativity, and accomplishment in the same spirit that would later infuse Hume's writings on industry. For example, in making the case that labour is the main source of human happiness, Hume describes how 'the mind acquires new vigour; enlarges its powers and faculties; and by an assiduity in honest industry, both satisfies its natural appetites, and prevents the growth of unnatural ones, which commonly spring up, when nourished by ease and idleness' (Hume 1752: 270). He adds, when people are 'kept in perpetual occupation ... [they] enjoy, as their reward, the occupation itself, as well as those pleasures which are the fruit of their labour' (ibid.).

Hume's discussion of work includes a subtle class distinction. ${ }^{13}$ For the most part he speaks of labour as having intrinsic virtues available to all industrious people. At times, however, he hints that such rewarding work experiences may be available only to his intended audience, the 'middling sorts'. For the rest of working society, labour is drudgery and exhibits the same kind of alienating features Adam Smith would later describe. Hume argued that hard labour tends to 'debase the minds of the common people, and render them unfit for any science and ingenious profession...' (ibid.: 198). ${ }^{14}$ He further suggests that in general we are what we do: 'the same principle of moral causes fixes the character of different professions, and alters even that disposition, which the particular members receive from the hand of nature. A soldier and a priest are different characters, in all nations, and all ages' (ibid.: 198). And, since the former 'use more labour of the body than that of the mind, they are commonly thoughtless and ignorant' (ibid.: 199). This suggests that Hume believed that common workers have different, less satisfying experiences of work than the middling sorts. Nevertheless, even though the general population are not able to derive the same intrinsic enjoyment from the process of work, Hume still reasons that they will benefit from the 
increased discipline and regularity of conduct, and that work will help steer them away from the 'unnatural appetites' that are 'nourished by ease and idleness' (ibid.: 270).

One element of Hume's campaign to rehabilitate work as a positive experience, perhaps especially for the common workers, was to call for a change in the way the wage was perceived. Hume challenged his predecessors who had argued that wages ought to be kept low for the dual purposes of forcing people to work diligently and making British goods competitive overseas. Hume suggested instead that labourers should be remunerated as liberally as possible, because this would create the best incentives for their industry. ${ }^{15}$ While such a measure might raise wages in Britain above those of its neighbours, it would not necessarily pose a problem, since the improved incentives, combined with superior technology, would contribute to making British workers more productive than their counterparts overseas and thus ensure that the effective cost of production would not exceed the international norm.

Commerce, the next transformational force advocated by Hume, was a crucial incentive to industry and a means for bringing people together in a civilising manner. In this we find echoes of Addison's and Montesquieu's praise of the civilising role of commerce. To them, commerce marginalises important sources of tension - such as nationality, religion, and politics - and creates a social space in which people can engage in peaceful and polite commerce. ${ }^{16}$ Hence, commerce brings people together in ways that increase their familiarity with difference and reduce their fear of the unknown. This prevents abstract ideas, such as religion and politics, from triggering hostility and ultimately from igniting armed conflict. In addition to eliminating destructive ignorance, commercial interaction also has a capacity to create a shared culture in which people gradually come to imitate each other's manners and habits. In the essay $O f$ National Character, Hume argues that, by bringing people together, and thus satisfying their natural bent for sociality, commerce allows a shared cultural experience; this experience inevitably socialises people to acquire a 'resemblance in their manners' (Hume 1748: 203). Optimistically, Hume believed that good manners and morals are contagious and that people are likely, on balance, to imitate the more sophisticated behaviours they encounter. In this sense, commerce is one of the most important vehicles for moral refinement and cultural improvement. ${ }^{17}$ Thus, for Hume, commerce has non-economic benefits that are at least as important as the augmentation of wealth. ${ }^{18}$

Hume departed from previous commentators who suggested that commerce has corruptive and effeminising effects. He argued that, as long as commerce is combined with industry and the arts, there is no reason why it should have a corrosive effect on society. In fact, he reasoned, once industry, commerce, and the arts come together, a higher level of civilisation is obtained in which 'laws, order, police, [and] discipline' are 
improved, 'mildness and moderation' are acquired, and 'factions are ... less inveterate, revolutions less tragical, authority less severe, and seditions less frequent' (Hume 1752: 273-4). Additionally, once a nation reaches a certain level of civilisation it tends to become less bellicose as it strives for empire through trade rather than the sword. Nevertheless, in the event that a war becomes necessary, its citizens will most likely exhibit greater martial spirit since their own prosperity and liberty will be at stake. Furthermore, the establishment of a culture of industry and commerce also contributes to national security by allowing the state to draw on its 'storehouse of labour' in case of national emergencies (ibid.: 272).

Another facet of commerce Hume famously commented on was luxury consumption. ${ }^{19}$ At the time Hume was writing, Europe had experienced its first real consumer revolution as a result of increased international trade and the exploitation of new areas and peoples. This led to the democratisation of luxury consumption, allowing people of all ranks to consume exotic colonial commodities and partake in the ever-changing world of fashionable clothing. While many moralists proclaimed that this new consumerism was a corruptive influence, intensifying many times over the corrosive effects of commerce, others, such as Mandeville, defended the new culture of desire on the grounds that it ignited industry and thus set the economy in motion. Although Hume leaned heavily towards the latter sentiment, he staked out a middle ground in this debate. He defended luxury consumption on the grounds that it generates a constant demand for new commodities, spurring more industry, additional commerce, and new innovations in the arts. As such, luxury consumption significantly enhances the benefits of commerce discussed above. Hence, although Hume thought that luxury consumption was rewarding in itself, he considered its primary benefits to be the added incentives for industry, commerce, and the arts - the key ingredients of the societal improvement process. Thus, even if there is a possibility that luxury consumption will turn vicious (for example, if it prevents people from carrying out their duties to friends, family, and the poor), it is, in Hume's mind, always 'preferable to sloth and idleness' (ibid.: 280).

The third civilising force Hume discussed was improvements in the arts. For Hume, as for other eighteenth-century writers, the arts was a broad category that included knowledge, inventiveness, skill, technique, and technology. ${ }^{20}$ Hume referred to both mechanical arts and liberal arts, suggesting that these two applications of human ingenuity are rather similar. In fact, there are important synergies between them, as Hume points out: 'The same age, which produces great philosophers and politicians, renowned generals and poets, usually abounds with skilful weavers, and ship-carpenters' (ibid.: 270). While the improvements in the arts are obviously instrumental in enhancing productivity and thus contributing to the wealth-creation process, they also yield important benefits that contribute to the broader civilisation process. Hume argued that improvements in 


\section{Carl Wennerlind}

the arts will banish ignorance, improve people's capacity for reason, and make them more sociable. Their curiosity in others will be piqued, their capacity for conversation multiplied, and their desire to show off their refinement intensified. This desire for sociability tends to make people more urbane and cosmopolitan, contributing importantly to a more polite and refined culture (ibid.: 271).

While Hume provided clear prescriptions for how to promote industry and commerce, he found it more difficult to specify the conditions under which the arts would flourish. He argued that there are certain stable causes that operate with consistency on the multitude, producing predictable results. An example of such a stable cause includes the 'desire of gain', which consistently brings about 'the rise and progress of commerce in any kingdom' (Hume 1742: 113). However, there are other principles or causes, operating on the few only, that are more accidental and influenced by 'whim and private fancy' (ibid.: 112). Curiosity and the love of knowledge are examples of such unpredictable causes. While these interests may sometime result in the formation of genius or important breakthroughs, such outcomes cannot be counted on to occur with great consistency. Hume therefore concludes that "chance ... or secret and unknown causes, must have a great influence on the rise and progress of all the refined arts' (ibid.: 114). That said, since Hume thought that great minds rarely spring from a vacuum, there must be some general explanation for why a certain nation or age is capable of producing genius more consistently. The answer lies in the societal features that generate a spirit of scientific innovation and artistic refinement. For Hume, the most important general causes of this spirit include a nontyrannical government ${ }^{21}$ and open communication among countries through commerce. ${ }^{22}$

Hume relied on industry, commerce, and the arts to enrich and civilise society. The people who were most active in these pursuits and thus most instrumental in transforming society belonged to the middling sorts. Comprised of merchants, manufacturers, lawyers, professionals, and gentry, the middling sorts embodied the new commercial, entrepreneurial, and innovative ethic that gradually undermined the old order. Empowered by knowledge and wealth that allowed them to maintain their political and economic independence, they became an important catalyst for transforming institutional structures and for encouraging others to follow in their path. Because of their economic independence they were the 'best and firmest basis of public liberty' (Hume 1752: 277), and because of their riches they became the envy of all others. They implemented laws conducive to commerce, industry, and the arts, and they educated their own children, as well as those of the aristocracy who had been tied to merchants as apprentices. Through a process of contagion and socialisation they gradually introduced a growing number of people to their way of life and, through this process, were able to solidify their political influence. ${ }^{23}$ 
This group was the basis of what Hume hoped would become a more polite and refined society. Because their frequent interactions in the market place had taught them to exercise mutual respect and politeness, they exhibited the most sociality and mildness of manners. In addition, they also displayed the greatest intelligence and ingenuity. As Hume claims in the essay Of the Middle Station of Life, there is 'a stronger Genius requisite to make a good Lawyer or Physician, than to make a great Monarch' (Hume 1742: 548). While nature and education are certainly important in determining a person's genius, only industry can 'carry it to any Degree of Perfection' (ibid.: 549). Because they had learned from experience that a person 'can never rise to any Distinction or Eminence in the World, without [their] own Industry' (ibid.: 548), the middling sorts tended to excel where other groups did not. Thus, the middling sorts served as a model of civility, politeness, and refinement, qualities Hume hoped would gradually spread throughout society and improve the manners and morals of the multitude. ${ }^{24}$

To summarise Hume's perspective then, when industry, commerce, and the arts come together and flourish in a mutually, reinforcing manner, society embarks on a self-sustaining process of economic, political, and cultural improvement. A set of incentives is established that propels the middling sorts to act in ways that solidify and reinforce the basic institutions of a commercial society, resulting in a prosperous economy. While it is necessary for the government to safeguard these institutions - property rights, markets, and money - and to commit to never 'impose any tax which hurts commerce and discourages industry' (Hume 1752: 358), ${ }^{25}$ few additional governmental interventions are required. Hence, Hume articulates a theory of how industry, commerce, and the arts have the capacity, as long as they are supported by the proper institutional and constitutional framework, to bring about the kind of improvements in civilisation that so many of his contemporary commentators sought. Hume's system, at least in its ideal form, was capable of generating all the benefits of politeness and sociability that Addison and Steele called for, as well as the civic virtues of public-mindedness and martial strength valued by the civic humanists. ${ }^{26}$ Additionally, Hume thought the expansion of commerce would empower the middling sorts to transform politics in ways that would ensure the nation's governance by laws rather than the whim and temper of dictatorial rulers - an insight for which Adam Smith would later praise him. ${ }^{27}$

\section{Constitutional form}

The formation and maintenance of an institutional framework within which industry, commerce, and the arts could flourish was Hume's primary concern. While he acknowledged the necessity of having a government to safeguard the rules and laws of society, he prescribed a 
rather limited role for it to play. This role included the protection of the nation from external threats and the maintenance of a system of justice, which meant securing property, markets, and money. Hume did not subscribe to any of the contemporary models regarding the origins of government. He disregarded both the Tory notion of an innate governmental authority and the Whig idea of contractually derived authority. Instead he argued that a citizen's allegiance to the government was rooted in the same interests and passions that had contributed to the establishment of society's foundational conventions. Hence, the same combination of passions and reason that led people to co-ordinate their behaviour in ways that made the conventions of society possible in the first place also ensured respect for and deference to the government. Therefore, the government had an intrinsic mandate to act in defence of the conventions.

While Hume addressed the necessity of the government safeguarding the institutions of a commercial society, he did not prescribe a particular constitutional form. ${ }^{28}$ He criticised the way in which Robert Walpole's Whigs had managed the political apparatus, but never identified as a Tory. Hume found many of his contemporaries' understanding of politics deeply flawed. He challenged the notion that there had ever been an ancient constitution in England with a perfect equilibrium between king, lords, and commons. Consequently he also denied that such a perfect balance had been re-established after the Glorious Revolution, a claim both the Whigs and the Tories maintained - the latter, of course, lamenting that the constitution had been sadly corrupted again shortly thereafter by Walpole. Instead of trying to take sides in the Whig-Tory debate, Hume argued for a complete reconceptualisation of British politics. Doing so would necessitate a new historical understanding of the constitution, a fresh perspective on party politics, and a modernised conception of the relationship between the polity and the economy - all of which Hume set out to accomplish. He suggested that the constitutional form was gradually becoming less relevant as the commercial system was increasingly operating autonomously from the political sphere. As such, as long as the constitution was based on stable foundations and the magistrate was capable of maintaining civil order by adequately enforcing the laws, it did not matter greatly whether a commercial society was managed by a civilised monarchy, a republic, or a mixed government. ${ }^{29}$ As such, Hume softened the republican-monarchical divide that had fuelled debates throughout the century preceding him.

Hume's ambivalence regarding the constitutional form manifested in a series of conflicting comments, some favouring a mixed constitution and others favouring a civilised monarchy. For example, Hume suggested that 'all reasonable men agree in general to preserve our mixed government' (Hume 1741: 65). This argument was motivated by concern that a polity made up of an absolute monarchy might be less likely to succeed in stew- 
arding a commercial society, not because property would be less secure, as some critics of absolute monarchies had argued, but rather because commerce was perceived as being less honourable in an absolute monarchy than in a mixed government. However, whether commerce was viewed as honourable or not was ultimately secondary to the concern about which political regime would be most successful in upholding the rule of law. Hume worried that a constitution centred on a party system would be prone to instability because political factions could ignite civil disorder or even civil war. In the end, it seems as though Hume's impression that the British mixed constitution was 'extremely delicate and uncertain' (ibid.: 64), combined with his intense aversion to party strife and faction, made him partial to an absolute monarchy of the French kind. ${ }^{30}$ This preference was reinforced when he looked towards the future. In the essay Whether the British Government inclines more to Absolute Monarchy, or to a Republic, Hume speculates whether it would be more favourable to have the British constitution evolve toward a republic or an absolute monarchy. He conjectures, 'there is no doubt, but a popular government may be imagined more perfect than absolute monarchy, or even than our present constitution' (ibid.: 52). However, he continues, 'But what reason have we to expect that any such government will ever be established in Great Britain, upon the dissolution of our monarchy?' (ibid.). In fact, as the disasters of Oliver Cromwell's militarisation of the republic had already shown, 'if any single person acquire power enough to take our constitution to pieces ... such a person will never resign his power, or establish any free government' (ibid.). Therefore, Hume concludes; 'I should rather wish to see an absolute monarch than a republic in this island' (ibid.). From his point of view, an absolute monarchy constitutes the best chance for long-term peace and stability. The most important role for the government is, after all, to maintain peace and stability by upholding the rule of law, because only under such circumstances do industry, commerce, and the arts abound.

\section{International commerce}

In the seventeenth century the Dutch Republic had demonstrated to its European neighbours the potential for international trade to enrich and empower a nation. In contrast to the Spaniards, who focused on geographical expansion and accumulation of gold and silver, the Dutch showed that a nation might grow even richer by engaging in the exchange and shipping of commodities, both domestic and foreign. England and Scotland quickly learned this lesson. England was first to challenge the Dutch, through the Navigation Acts and later in direct military engagements. As a consequence of its success, by the end of the century England's trading network was rapidly expanding. Soon thereafter, Scotland made a valiant attempt to gain a share of the expanding world trade, 
but encountered limited success. Feeling squeezed by the established colonial powers, the Scots embarked on an ambitious plan to establish a trading entrepôt at Darien, in present-day Panama. While the Darien scheme attracted much of the nation's liquid capital and raised the hopes of many Scots, it ended in a desperate failure, with many men and much of the country's wealth lost. As a result, Scotland changed strategies and bartered away its constitutional independence for access to the rapidly expanding English empire. While it took a generation for the constitutional union to bear fruit, Hume was genuinely convinced that the Union was, and would continue to be, greatly advantageous to Scotland, as well as to England, because he firmly believed that the freer the trade, the better it would be for all involved.

Hume was a staunch defender of open international commerce. The crucial feature in Hume's argument that allowed him to stake out such unqualified support for open commerce was his belief that international trade was not a zero-sum game. ${ }^{31}$ Instead he argued that international trade rewards all participants by expanding their commerce and by bringing about a host of benefits associated with flourishing commerce. These benefits include all those that were mentioned in the above discussion about commerce in general, as well as the additional benefits that Hume details in the essay Of Commerce. He argues that by bringing in new commodities, which can serve as raw material, and by generating a greater demand for domestic commodities, a vibrant import-and-export trade stimulates additional industry on all ends. This means that not only will people be able to enjoy a greater array and quantity of goods, but, since a larger number of labourers will be employed, all the benefits of increased industry discussed above will also follow. Hume further believed that a thriving international trade and its potentially spectacular profits play an important role in recruiting a growing number of people to the life of industry and trade. It is through international commerce that 'men become acquainted with the pleasures of luxury and the profits of commerce; and their delicacy and industry, being once awakened, carry them on to farther improvements, in every branch of domestic as well as foreign trade' (Hume 1752: 264, emphasis in original). ${ }^{32}$

We have already seen above how open communication among countries was for Hume one of the most important features in the progress of the arts and sciences, as well as in the refinement of morals and manners. Emulation and imitation were also crucial ingredients in the economic growth process. Hume was convinced that, had it not been for the revolutions in technology and techniques that England imported from abroad, its agriculture and manufacturing would still be stuck in a rude and primitive state. Instead, during his time, England continued to benefit greatly from its imitation of foreigners. 'Notwithstanding the advanced state of our manufactures,' Hume observes, 'we daily adopt, in every art, the inventions and improvements of our neighbours' (Hume 1758: 328). The 
important synergies generated by the sharing of new developments in science and technology led Hume to famously proclaim that "not only as a man, but as a British subject, I pray for the flourishing commerce of Germany, Spain, Italy, and even France itself' (ibid.: 331).

Not surprisingly, Hume opposed most attempts by the state to restrict international commerce. In particular, he polemicised against restrictions motivated by the fear that international trade might drain specie and thus diminish domestic production. Hume found such concerns misguided and tried to reassure his readers that the specie-flow mechanism always preserves 'money nearly proportionable to the art and industry of each nation' (Hume 1752: 312). Since the art and industry of each nation determine the size of both its commodity circulation and its money stock, the state should never interfere with the flow of either goods or money. All the state should do is encourage industry and commerce and promote the diffusion of the arts. Hume also opposed efforts by the state to protect industries that were unable to compete successfully in the global market place because their wages were too high or productivity too low. Instead, the legislator should leave the international market dynamic alone to guide what commodities each nation should produce. If the specie-flow mechanism is free to operate unhampered it will create incentives for advanced nations to focus on high-skill and capital-intensive sectors, which will open up the possibility for poorer, low-wage nations to grow by specialising in low-skill and labour-intensive production. According to Hume, nations with a steady improvement in industry, commerce, and the arts are likely to experience a gradual inflow of money that eventually will put an upward pressure on wages. In sectors where the advanced nations have a competitive edge, whether due to skill advantages, better technology, or capital requirements, their competitiveness is likely to remain intact despite the higher wages. However, in the lower-skill sectors, the advanced nations are unlikely to remain competitive. Hume advises the advanced nations not to remain too attached to these sectors. Instead they should calmly allow the low-wage nations to control the 'simple and more laborious' sectors, while they themselves concentrate on the sectors that 'require great stock or great skill' (Greig 1932: 143) ${ }^{33}$ While this international market dynamic does not guarantee convergence among rich and poor countries, it ensures that the 'growth of trade and riches ... [is not] confined entirely to one people' (283). ${ }^{34}$ Hence, government interference in the global market dynamic has the capacity to derail what Hume believed could be a beneficial march of progress involving both rich and poor nations.

\section{Money, credit, and interest}

Hume wrote during a vibrant moment in the history of money and credit. The memories of the South Sea and Mississippi bubbles were still fresh and 
fears about the unsustainability of a ballooning national debt had been gathering force for some time. A large literature on money and credit had emerged, in which political economists debated the possibilities and dangers of paper credit. Some, like John Law and George Berkeley, argued that the intrinsic properties of money are of secondary importance and that paper money can usefully be employed to stir up industry and thus provide a solution to the employment problem. Others, such as John Locke and Richard Cantillon, disagreed with such anti-foundationalist views and insisted that only money comprised of silver or gold has the capacity to adequately mediate exchange. Hume forged a middle ground in this debate. While he did not principally oppose the use of private and public credit, he was concerned with what he perceived to be a lack of discipline on the part of the issuers and users of these credit instruments. Hume outlined a non-metallist theory of money in the Treatise, in which he suggested that the key ingredient of a successful currency is the trust and confidence people have in its ability to be exchanged. He developed this theory further in the Political Discourses, arguing that money is a conventional mediation device, with a fictitious value, that serves as an oil of commerce, making the 'wheels of trade ... [turn] more smooth and easy' (Hume 1752: 281). However, while in the Treatise he seems open to any form of currency, in the Political Discourses he expresses hesitance about paper money. The reason behind this emerging reluctance was his suspicion that the money-issuing authorities would not act in a disciplined manner and would be tempted to expand the money stock too much. Although he does not completely rule out the use of privately issued paper money, he limited his support to paper currencies that were fully backed by either specie or, at a minimum, bills of exchange payable in specie. ${ }^{35}$

Hume's reluctance regarding the use of paper money was related to his objection to the artificial expansion of the nation's money supply. While governments undertook such inflationist initiatives to stimulate additional industry, Hume viewed them as distractions at best and disasters at worst. In general, the expansion of paper money would only bring about the inconvenience of a rising price level, but in less fortunate circumstances the expansion of paper money could destabilise the entire monetary mechanism. In fact, Hume believed that the state's involvement in the monetary system should be limited to safeguarding the basic conventions and that it should resist the temptation of trying to regulate the quantity of money in circulation. He believed, as we saw in the previous section, that the optimal quantity of money for a nation was that which is proportional to its industry, commerce, and arts. As long as goods and money are allowed to flow freely between nations, the specie-flow mechanism ensures that each nation attracts the appropriate quantity of money. Hence, the quantity of money should be regulated by the discipline of the specie-flow mechanism, which ultimately means that it is determined by each nation's industry, commerce, and arts. 
Even though Hume opposed attempts by the state to artificially engineer a systematic increase in the quantity of money, he nevertheless favoured an inflow of money over an outflow of money. There were two main reasons for his opinion. First, he argued that a steady inflow of money resulting from a trade surplus is a sign that the nation's industry, commerce, and arts are flourishing. This is, of course, the kind of prosperity and riches 'which are the end of all our wishes' (ibid.: 284). Second, the inflow of money from trade also comes with its own benefits - a multiplier process that provides a further boost to industry. The basic dynamic of this process is as follows. When a nation experiences an increase in industry, commerce, and the arts there is an expansion in the number of commodities produced and a consequent fall in the prices of those goods. This creates a situation in which the nation is likely to increase its exports, since gold now has greater purchasing power in the prosperous nation. The resulting inflow of money ends up in the hands of the merchants and manufacturers in the exporting sectors. They, in turn, seek to build on their success by expanding their businesses further. In addition to adding more physical capital, they are also required to increase productivity or hire more workers. While it may be possible to induce additional improvements in intensity or efficiency, the manufacturers are ultimately required to hire more workers, putting an upward pressure on wages and thus on output prices in that sector. The wage increases for the workers in the export industries increase the workers' real wealth, as prices in the rest of the economy remain the same. The enriched worker now 'carries his money to market, where he finds every thing at the same price as formerly, but returns with greater quantity and of better kinds, for the use of his family' (ibid.: 287). Hence, the increased real wages expand the effective demand for goods in the rest of the economy. Manufacturers, farmers, and craftspeople increase their industry to meet the added demand and, in return, they too experience an increase in income. This leads to the hiring of more workers, forcing up wages and thus output prices in the rest of the economy. However, as long as all prices have not increased proportionally, each wage increase still translates into a real wealth improvement and thus leads to additional consumption, spreading the multiplier process throughout the economy. Eventually, when all prices have adjusted, the multiplier process peters out, but only after having given an important boost to industry.

It is important to point out here, though, that Hume believed that only an inflow of money that stems from a prior increase in industry, commerce, and the arts has the capacity to launch the multiplier process. Hence, the multiplier should be thought of as a transmission of productivity improvements throughout the economy rather than purely a monetary phenomenon. Consequently, the government has no monetary policy lever, of the sort that had been tried earlier in the eighteenth century, to stimulate industry. Instead, the government's primary role is to create the 
proper legal context in which industry, commerce, and the arts can flourish. If successfully undertaken, this will eventually bring about the added boost of the multiplier process. ${ }^{36}$

In addition to his suspicion about the inability of the state to maintain discipline over the monetary system, Hume was also concerned about the government's lack of discipline in managing the public debt. He believed that the practice of mortgaging future public revenues and trusting that future generations would pay for the expenditures undertaken by their ancestors was a breach of intergenerational consideration. Even more troubling was that the debt could bankrupt the entire nation because there was no built-in limit on how much debt the state could accumulate. ${ }^{37}$ The strong temptation to defer payment of costly military campaigns and popular public works to the future means that the practice of 'contracting [a public] debt will almost infallibly be abused, in every government' (ibid.: 352). Hume adds, 'It would scarcely be more imprudent to give a prodigal son a credit in every banker's shop in London, than to impower a statesman to draw bills, in this manner, upon posterity.'

Even though Hume was negatively disposed to the public debt, he still considered the possible benefits to industry and commerce of the interestbearing notes and bills issued by the government in their effort to raise money. He perceived numerous benefits associated with these public securities, which circulated as 'a kind of money' (ibid.: 353), but, in the end, when the benefits were compared with the many disadvantages of public debts, Hume opined, 'You will find no comparison between the ill and the good which result from them' (ibid.: 354). So concerned was he with the possible dangers of the public debt that he famously proclaimed, 'either the nation must destroy public credit, or public credit will destroy the nation' (ibid.: 360-1)..$^{38}$

While Hume had little confidence that the government could maintain proper discipline over paper credit and public credit, he was absolutely convinced that the government was entirely incapable of altering the price of credit, that is, the interest rate. Once again, Hume attacked the inflationists who believed that an increase in the money stock could force the interest rate down. Hume demonstrated that, while there is a correlation between the quantity of money and the interest rate, there is no causal tie between them. Instead both the quantity of money and the interest rate are determined by the level of industry and commerce in a nation. While we have already seen above how the quantity of money adjusts to the level of industry and commerce through the specie-flow mechanism, let us now look at how the interest rate is determined by industry and commerce in the following three ways. First, when industry, commerce, and the arts flourish there are great supplies of wealth available for lending. These supplies come from the accumulated wealth of the prosperous merchants, who tend to be frugal with their money and always seek to employ it to their advantage. Second, during times of commercial expansion more and 
more people are engaged in productive pursuits, reducing the number of prodigal landowners who tend to live beyond their means, relying on borrowed money to maintain their lifestyles. Third, when the economy is growing rapidly, profits tend to fall, which through the arbitrage mechanism creates a downward pressure on interest rates. That is, during prosperous times the industrious middling sorts increase in number, generating more competition and thus a tendency for profits to fall. As we have seen above, the expansion of industry and commerce also has a tendency to reduce the interest rate. Thus, the level of industry and commerce causes profits and the interest rate to move in the same direction. What ensures that profits and interest tend to converge is that 'No man will accept of low profits, where he can have high interest; and no man will accept of low interest where he can have high profits' (ibid.: 303). As money flows to the sector with the higher rate of return, this rate gradually falls until the returns from commerce and from money lending are equalised.

In sum, Hume's writings on money and credit convey a coherent message to the legislator: never interfere with money or credit unless it is absolutely necessary. While the state needs to protect the basic foundations of the monetary system, it should trust that the monetary mechanism works best when left alone. In the event that the state decides to issue paper money or public securities, the guiding principle should always be discipline. However, Hume did not have much confidence in the government's ability to resist the temptation of manipulating money and credit for short-term gain. An active monetary policy was therefore not a feasible option.

\section{Conclusion}

Hume was both a visionary thinker and a practical political strategist. He believed that commercial modernisation would fundamentally transform the way people lived, worked, and interacted. He was convinced that with the proper social structure and accompanying constitutional form the confluence of industry, commerce, and the arts had the capacity to emancipate society from 'ignorance, sloth, and barbarism' (Hume 1758: 328) and usher in a new culture of 'industry, knowledge, and humanity' (Hume 1752: 271). ${ }^{39}$ According to Hume, the commercial modernisation process enriches people and the state, facilitates civilisation and refinement, and encourages the establishment of the rule of law. In this sense, he can be seen as one of the most ardent, unapologetic defenders of the emerging commercial society, perhaps even more so than John Locke and Adam Smith.

In addition to his broader visionary concerns, Hume was also interested in the details of the commercial modernisation process. He carefully crafted essays on money, trade, public credit, interest rates, and taxes that included detailed advice to citizens and the legislator. The central policy 
concern permeating all of his writings on political economy is that the state's engagement with the economy should be kept to a minimum. While the state should always protect the foundational conventions, it should trust that commerce, industry, the arts, the international specieflow mechanism, and the system of money and credit have the capacity to co-ordinate society in ways that promote economic progress, political liberty, and civilisation. If the state nevertheless decides to intervene in the economy, the guiding criteria should always be the encouragement of industry, commerce, and the arts. Such interventions must also be undertaken with the utmost discipline to make sure that the state does not jeopardise the long-term health of the economy by pursuing its own short-term interests. Through his writings, Hume tried to bring attention to the deleterious effects of the state operating in unsystematic and opportunistic ways. He tried to teach the legislator that the 'greatness of a state, and the happiness of its subjects ... [are] inseparable with regard to commerce ... [and] the public becomes powerful in proportion to the opulence and extensive commerce of private men' (ibid.: 255). By instructing the legislator about the proper functioning of the economy and the benefits to the state of a flourishing economy, he hoped that his economic ideas would restructure the political practices of the legislator.

\section{Notes}

1 For full biographical information see Mossner (1954).

2 Hume's primary audience was the so-called middling sorts, the group he thought had the greatest facility for reason and the greatest capacity and determination to reform society. He writes about the middling sorts as 'the most numerous Rank of Men, that can be suppos'd susceptible of Philosophy; and therefore, all Discourses of Morality ought principally to be address'd to them'. He adds, 'the Great are too much immers'd in Pleasure; and the Poor too much occupy'd in providing for the Necessities of Life, to hearken to the calm Voice of Reason' (Hume 1752: 546).

3 While philosophers and economists have contributed to an ahistorical understanding of Hume's political economy by reading him as a participant in a series of timeless debates, numerous historians of ideas have lately begun to study the formation of Hume's thinking within his own political, economic, scientific, and social context. Examples of this trend include Hont (1983), Phillipson (1989), Schabas (2001), Caffentzis (2001), Emerson (2006), Ross (2006), and Dimand (2006). For a treatment of why Hume's writings have given rise to so many different interpretations, see Dow (2002).

4 While in the Political Discourses Hume's focus on contemporary political and economic issues is obvious, his History of England also seems intended to affect contemporary political debates by revising the historical understanding that had informed earlier political polemics. In the words of Nicholas Phillipson, 'the History was written to a specific agenda ... to discover the origins of the modern constitution and the party system and to show exactly on what foundations it had been built' (1989: 11). By so doing, Hume hoped to pave the way for the acceptance of his policy prescriptions.

5 Hume, in the essay Of Commerce, praises the philosophers' consideration of the 
'general course of things and their capacity for 'universal propositions' (1752: 254-5). He juxtaposes their abstruse thinking to that of the coffee-house crowd who tend to form their shallow arguments on singular experiences or observations. He thought it was particularly important to bring the philosophers' way of thinking to bear on contemporary political and economic issues because 'they are commonly treated in the loosest and most careless manner' (ibid.: 304).

6 This essay provides an overview of Hume's thinking as a political economist. Because of space considerations there are multiple facets of his thinking and context that are omitted. For a recent synthetic treatment of Hume's political economy, see Skinner (1993). For the fullest account to date, see Rotwein (1955).

7 Hume writes in the essay Of Avarice, 'though there scarcely has been a moralist or philosopher, from the beginning of the world to this day, who has not levelled a stroke at [avarice], we hardly find a single instance of any person's being cured of it' (1741: 571).

8 Hume's discussion of these matters can be found in Book III of the Treatise.

9 Hume writes in Of the Rise and Progress of the Arts and Sciences that 'Avarice, or the desire of gain, is an universal passion, which operates at all times, in all places, and upon all persons' (Hume 1742: 113).

10 For a more detailed elaboration on the formation of the conventions, see Stewart (1963), Berry (1997), and Wennerlind (2001, 2002). For additional examples of commercial interpretations of the Treatise, see Schabas (1994), Soule (2000), and Davis (2003).

11 Addison and Steele proclaimed proudly that they had 'brought Philosophy out of Closets and Libraries, Schools and Colleges, to dwell in Clubs and Assemblies, at Tea-Tables and in Coffee Houses' (1711: 166). They thought that social interaction had the capacity to teach people tolerance, moderation, and politeness. These virtues would then take the edge off people's possessive individualism, which the new commercial society otherwise encouraged.

12 Remarkably scant attention has been given to the centrality of work in Hume's political economy. Few scholars emphasise, as does E. J. Hundert, that Hume's political economy 'was the most thoroughgoing commitment to the moral and material efficacy of work since Locke' (1974: 141-2). Recent exceptions to this neglect include Marshall (2000) and Tanaka (2004).

13 For a discussion of the role of class in Hume's discussion, see Stockton (1976) and Wennerlind (2002).

14 Compare this statement with Smith's famous discussion of how the division of labour tends to make the majority of workers unable to 'exert [their] understanding, or to exercise [their] invention in finding out expedients for removing difficulties' during the labour process. They therefore become 'as stupid and ignorant as it is possible for a human creature to become' (1776: 303).

15 Hume thought, for the most part, that positive incentives for labour were preferable to coercive pressure: 'It is a violent method, and in most cases impracticable, to oblige the labourer to toil, in order to raise from the land more than what subsists himself and family. Furnish him with manufactures and commodities, and he will do it himself' (ibid.: 262). He later adds, 'Every person, if possible, ought to enjoy the fruits of his labour, in a full possession of all the necessaries, and many of the conveniences of life' (ibid.: 265).

16 Addison celebrates the Royal Exchange for the way that it brings people from all over the world together and turns every participant into a 'Citizen of the World' (1711: 212). Montesquieu later expanded upon this notion in his formulation of the concept of doux commerce, which proclaimed that 'everywhere there are gentle mores, there is commerce and that everywhere there is commerce, there are gentle mores' (1748: 338). 
17 As Hume elaborates in the essay Of National Character, communication is one of the most central determinants of morals and manners. He writes, "where several neigbouring nations have a very close communication together, either by policy, commerce, or traveling, they acquire a similitude of manners, proportioned to the communication' (ibid.: 206). For Hume, commerce was as much about the exchange of commodities as it was about the communication between people. In this, he closely follows Montesquieu's idea that 'the history of commerce is that of communication among peoples' (1748: 357).

18 For recent work on Hume's discussion of civilisation and commerce, see Boyd (2006) and Berry (2006b).

19 Recent work on Hume's notion of luxury includes Cunningham (2005) and Berry (2006a).

20 For a discussion of the connotation of the term 'arts' in the seventeenth and eighteenth centuries, see Johnson (1965).

21 Hume writes in Of the Rise of Arts and Sciences that people living under a tyrannical government 'are slaves in the full and proper sense of the word; and it is impossible they can ever aspire to any refinements of taste or reason' (ibid.: 117).

22 Hume suggests that open communication between nations leads to healthy competition, likely to spark further refinement. He writes in Of the Rise of Arts and Science "where a number of neighbouring states have a great intercourse of arts and commerce, their mutual jealousy keeps them from receiving too lightly the law from each other, in matters of taste and of reasoning, and makes them examine every work of art with the greatest care and accuracy' (ibid.: $120)$.

23 Hume suggests that "where luxury nourishes commerce and industry, the peasants, by a proper cultivation of the land, become rich and independent; while the tradesmen and merchants acquire a share of the property, and draw authority and consideration to that middling rank of men, who are the best and firmest basis of public liberty. These submit not to slavery, like the peasants, from poverty and meanness of spirit; and having no hopes of tyrannizing over others, like the barons, they are not tempted, for the sake of that gratification, to submit to the tyranny of their sovereign. They covet equal laws, which may secure their property, and preserve them from monarchical, as well as aristocratical tyranny' (ibid.: 277-8).

24 Hume provides a theory of civilisation that is potentially inclusive of all people. As Richard Boyd (2006) has pointed out, while Aristotelian and civic republican notions of civility were limited to a select few, there is nothing in Hume's discussion that suggests that a person could be barred from inclusion among the middling sorts. The only qualifying characteristics are behavioural, which are open to all to emulate.

25 Hume favoured taxes on luxury consumption because they do not impose hardship on the poor and have a built-in upper limit, since there comes a point when higher taxes will reduce consumption and thus decrease total tax revenues. The worst taxes, according to Hume, are the arbitrary taxes, which commonly function as 'punishments on industry' (ibid.: 345).

26 For a full treatment of how Hume's social and political thought relates to that of the civic republican tradition, see Finlay (2004).

27 Smith acknowledges that 'Mr Hume is the only writer who, so far as I know, has hitherto taken notice' of the fact that 'commerce and manufactures gradually introduce order and good government, and with them, the liberty and security of individuals' (1776: 433).

28 As Fania Oz-Salzberger has pointed out, Hume's political analysis took as its subject the maintenance of justice, rather than 'forms of government or modes 
of participation and representation' (2003: 169). Hume was not, however, completely agnostic when it came to constitutional form. He argued in Of National Characters that one of the most important determinants of a people's manners and morals is its government. When a government becomes oppressive it has a proportional effect on people's 'temper and genius, and must banish all the liberal arts from among them' (Hume 1748: 198). Hence, Hume's ambivalence is limited to the choice among modern civilised monarchies, republics, and mixed constitutions, and does not include ancient tyrannical regimes.

29 In the essay Of the Rise and Progress of the Arts and Sciences Hume argues that initially the arts and sciences could have developed only in a republic, but once established they could prosper as well in a civilised monarchy as they could in a republic. In the essay Of Civil Liberty, Hume argues more generally that even though the civilised monarchy owes its perfection to the republics "it may now be affirmed of civilized monarchies, what was formerly said in praise of republics alone, that they are a government of Laws, not of Men... Property is there secure; industry encouraged; [and] the arts flourish' (Hume 1741: 94, emphasis in original). One slight difference was that the sciences are best supported in a civilised monarchy, while the polite arts are best encouraged in a republic (Hume 1742: 126).

30 In the essay Of Parties in General, Hume explains that 'factions subvert government, render laws impotent, and beget the fiercest animosities among men of the same nation, who ought to give mutual assistance and protection to each other' (Hume 1741: 55). He compares factions to weeds and suggests that republics provide its most fertile soil.

31 Hume observes that many nations 'look upon their neigbours with a suspicious eye' and considers 'all trading states as their rivals' (Hume 1758: 328). He, on the other hand, asserts that 'the encrease of riches and commerce in any one nation, instead of hurting, commonly promotes the riches and commerce of all its neighbours...' (ibid.: 328)

32 For a treatment of Hume's views on international commerce, see Berdell (1996).

33 The cessation of production in a particular sector may create temporary hardship for some workers, but Hume believed that as long as 'the spirit of industry be preserved [they] may easily be diverted from one branch to another; and the manufacturers of wool, for instance, be employed in linen, silk, iron, or any other commodity' (Hume 1758: 330).

34 For a detailed discussion about the rich country-poor country debates, see Hont (1983) and Elmslie (1995).

35 For a more detailed elaboration on the themes discussed in this paragraph, see Wennerlind (2001) and Caffentzis (2001).

36 For a detailed account of the multiplier process and the role of the government, see Wennerlind $(2005,2006)$. For slightly different interpretations, see Duke (1979), Berdell (1995), Cesarano (1998), and Sakamoto (2003).

37 Hume writes that 'The public is a debtor, whom no man can oblige to pay.' He continues, 'The only check which the creditors have upon her, is the interest of preserving credit; an interest, which may easily be overbalanced by a great debt, and by a difficult and extraordinary emergence, even supposing that credit irrecoverable' (Hume 1752: 364).

38 For a full analysis of Hume's discussion of the national debt, see Hont (1993).

39 For a detailed elaboration on the juxtaposition of these two trios, see Berry (2006b). 


\section{References}

Addison, Joseph and Richard Steele ([1711] 1979) The Spectator, edited by Gregory Smith, New York: Dutton.

Berdell, J. F. (1995) 'The Present Relevance of Hume's Open-Economy Monetary Dynamics', Economic Journal 105 (September): 1205-17.

- (1996) 'Innovation and Trade: David Hume and the Case for Freer Trade', History of Political Economy 28, 1: 107-26.

Berry, Christopher (1997) Social Theory of the Scottish Enlightenment, Edinburgh: Edinburgh University Press.

— (2006a) 'Hume and Superfluous Value (or the Problem with Epictetus' Slippers)', in C. Wennerlind and M. Schabas (eds), Essays on David Hume's Political Economy, London: Routledge.

- (2006b) 'Hume and the Customary Causes of Industry, Knowledge, and Humanity', History of Political Economy, forthcoming.

Boyd, Richard (2006) 'Manners and Morals: David Hume on Civility, Commerce, and the Social Construction of Difference', in C. Wennerlind and M. Schabas (eds), Essays on David Hume's Political Economy, London: Routledge.

Caffentzis, George (2001) 'Hume, Money, and Civilization: or Why was Hume a Metallist?', Hume Studies 27, 2: 301-35.

— (2006) 'Fiction and Counterfeit? Hume's Philosophical Politics of Money', in C. Wennerlind and M. Schabas (eds), Essays on David Hume's Political Economy, London: Routledge.

Cesarano, Filippo (1998) 'Hume's Specie-flow Mechanism and Classical Monetary Theory: an Alternative Interpretation', Journal of International Economics 45, 1: 173-86.

Cunningham, Andrew (2005) 'The Development of Hume's Thought on Luxury', Journal of History of Economic Thought, forthcoming.

Davis, Gordon (2003) 'Philosophical Psychology and Economic Psychology in David Hume and Adam Smith', History of Political Economy 35, 2: 269-305.

Dimand, Robert (2006) 'David Hume and Canadian Paper Money', in C. Wennerlind and M. Schabas (eds), Essays on David Hume's Political Economy, London: Routledge.

Dow, Sheila (2002) 'Interpretation: the Case of David Hume', History of Political Economy 34, 2: 399-420.

Duke, Michael (1979) 'David Hume and Monetary Adjustment', History of Politica Economy 11, 4: 572-87.

Elmslie, Donald (1995) 'The Convergence Debated between David Hume and Josiah Tucker', Journal of Economic Perspective 9, 4: 207-16.

Emerson, Roger (2006) 'The Scottish Contexts for Hume's Political-Economic Thinking', in C. Wennerlind and M. Schabas (eds), Essays on David Hume's Political Economy, London: Routledge.

Finlay, Christopher (2004) 'Hume's Theory of Civil Society', European Journal of Political Theory 3, 4: 369-391.

Greig, J. Y. T. (1932) The Letters of David Hume, Oxford: Clarendon Press.

Hont, Istvan (1983) 'The 'Rich Country - Poor Country' Debate in Scottish Classical Political Economy', in I. Hont and M. Ignatieff (eds), Wealth and Virtue: The Shaping of Political Economy in the Scottish Enlightenment, Cambridge: Cambridge University Press. 
(1990) 'Free Trade and the Economic Limits to National Politics: Neo-Machiavellian Political Economy Reconsidered', in John Dunn (ed.), The Economic Limits to Modern Politics, Cambridge: Cambridge University Press.

— (1993) 'The Rhapsody of Public Debt: David Hume and the Voluntary State Bankruptcy', in N. Phillipson and Q. Skinner (eds), Political Discourses in Early Modern England, Cambridge: Cambridge University Press.

Hume, David ([1739-40] 1978) A Treatise of Human Nature, Oxford: Clarendon Press.

— ([1741, 1742, 1748, 1752, 1758] 1985) Essays: Moral, Political, and Literary, Indianapolis IN: Liberty Fund.

— ([1754-62] 1983) The History of England, Indianapolis IN: Liberty Classics.

Hundert, E. J. (1974) 'The Achievement Motive in Hume's Political Economy', Journal of the History of Ideas 35, 1: 139-43.

Johnson, E. A. J. ([1937] 1965) Predecessors of Adam Smith, New York: Kelley.

Marshall, Mike (2000) 'Luxury, Economic Development, and Work Motivation: David Hume, Adam Smith, and J. R. McCulloch', History of Political Economy 32, 3: 631-48.

Montesquieu ([1748] 1989) The Spirit of the Laws, Cambridge: Cambridge University Press.

Mossner, E. C. ([1954] 1980) The Life of David Hume, Oxford: Oxford University Press.

Oz-Salzberger, Fania (2003) 'The Political Theory of the Scottish Enlightenment', in C. Wennerlind and M. Schabas (eds), Essays on David Hume's Political Economy, London: Routledge.

Phillipson, Nicholas (1989) Hume, London: Weidenfeld \& Nicolson.

Ross, Ian Simson (2006) 'Emergence of Hume as a Political Economists: a Biographical Sketch', in C. Wennerlind and M. Schabas (eds), Essays on David Hume's Political Economy, London: Routledge.

Rotwein, Eugene ([1955] 1970) David Hume: Writings on Economics, Madison WI: University of Wisconsin Press.

Sakamoto, Tatsuya (2003) 'Hume's Political Economy as a System of Manners', in The Rise of Political Economy in the Scottish Enlightenment, London: Routledge.

Schabas, Margaret (1994) 'Market Contracts in the Age of Hume', in Neil de Marchi and Mary Morgan (eds), Higgling: Transactors and their Markets in the History of Economics, History of Political Economy supplement 26: 117-34.

— (2001) 'David Hume on Experimental Natural Philosophy, Money and Fluids', History of Political Economy 33, 3: 411-35.

Skinner, Andrew (1993) 'David Hume: Principles of Political Economy', in David Norton (ed.), Cambridge Companion to Hume, New York: Cambridge University Press.

Smith, Adam ([1776] 1976) An Inquiry into the Nature and Causes of the Wealth of Nations, Chicago: University of Chicago Press.

Soule, Edward (2000) 'Hume on Economic Policy and Human Nature', Hume Studies 26, 1: 143-58.

Stewart, John (1963) The Moral and Political Philosophy of David Hume, Westport CT: Greenwood Press.

Stockton, Constant (1976) 'Economics and the Mechanism of Historical Progress in Hume's History', in Donald Livingston and James King (eds), Hume: A Reevaluation, New York: Fordham University Press. 


\section{Carl Wennerlind}

Tanaka, Hideke (2004) 'Characteristics and Significance of Hume's Idea of Labour, or Industry', presented at the XXXIst Annual Hume Society Conference in Tokyo.

Wennerlind, Carl (2001) 'The Link between David Hume's A Treatise of Human Nature and his Fiduciary Theory of Money', History of Political Economy 33, 1: $139-60$.

(2002) 'David Hume's Political Philosophy: a Theory of Commercial Modernization', Hume Studies 28, 2: 247-70.

- (2005) 'David Hume's Monetary Theory Revisited: Was he Really a Quantity Theorist and an Inflationist?' Journal of Political Economy 113, 1: 223-37.

(2006) 'An Artificial Virtue and the Oil of Commerce: a Synthetic View of Hume's Theory of Money', in C. Wennerlind and M. Schabas (eds), Essays on David Hume's Political Economy, London: Routledge. 


\title{
5 Sir James Steuart, Principles of Political Oeconomy ${ }^{1}$
}

\author{
Andrew S. Skinner
}

\section{Biographical notes}

The Steuart family ${ }^{2}$ owned two estates, Goodtrees, which is near Edinburgh, and Coltness on the outskirts of Glasgow. Goodtrees was the seat of Sir James Steuart, the second baronet, Solicitor General and a member of the Union Parliament. Sir James married Anne Dalrymple, the eldest daughter of the Lord President of the Court of Session, by whom he had five children, of whom James was the only son. James was born on 10 October 1713, presumably at Goodtrees.

James attended the parish school at North Berwick, proceeding in due course to Edinburgh University where he studied, inter alia, constitutional and Scots law. Thereafter James made the expected progression and passed the Bar examinations in 1735 at the age of twenty-two.

Steuart became the third Baronet in 1727 on the death of his father but did not spend time either in enjoying his new status or his standing as an advocate. Rather he embarked upon a foreign tour (1735-40). It was during this period that he lost his remarkable mother, an event which may have affected his future fate.

Steuart travelled with a fellow advocate, Carnegie of Boysack, and the pair initially went to Holland, where they pursued further study. But in due course they travelled through France, settling for a period in Avignon. Avignon was at this time a Papal Territory and a haven for those Scots who had been 'out' in the Jacobite rebellion of $1715.3^{2}$ It was here that Steuart met the Duke of Ormond, a fervent supporter of the Cause who in turn directed Steuart's steps to Madrid, where he met the Earl Marischall, another of the architects of the ill-fated '15. It may have been the influence of these two men that directed Steuart's steps to Rome in the late 1730s. Steuart seems to have been captivated by the Old Pretender and his staff (there is very little mention of Prince Charles) and in a way which was to have a profound influence upon his future.

Steuart met Lord Elcho in Lyons, en route home, and it may be that he persuaded the future commander of the Prince's Life Guards to join the movement. In any event Steuart was active on behalf of the Jacobites after 
his return to Scotland in 1740 and it was because of this that he was sent to France as ambassador in 1745, following the success at Prestonpans. But after the battle of Culloden in April 1746 Steuart entered a long period of exile and to begin with maintained an active link with the party. But the early 1750 s saw a withdrawal from the Jacobite interest and Steuart, together with Lord Elcho, eventually settled in Angoulême, where they lived in some style, with the support of Elcho's mother.

Steuart was bored, however, and it was probably significant that the exiled Parlement of Paris came to the locality in 1753. It was here that Steuart met Mercier de la Rivière, the latter-day Physiocrat so much admired by Adam Smith, with whom Steuart formed a long and lasting friendship. When the Parlement returned to Paris in 1754 Steuart followed, where he was entertained by Mercier de la Rivière and probably introduced to Montesquieu and Mirabeau.

The scientific opportunities were considerable, but in fact Steuart left Paris and France in 1755 to avoid compromising his position further in the event of hostilities with Britain. He left Paris in short before the dissemination of the Tableau Economique. The first two books of the Principles were completed in the isolation of Tübingen (Germany) by August 1759 .

The Steuart family left Tübingen in 1761 following Lord Barrington's successful attempt to have Steuart's son, also James, appointed as a cornet in the British Dragoons. They travelled west to Rotterdam and Antwerp before settling temporarily in the Spa, near Liège. It was here that Steuart was arrested by the French authorities and subsequently imprisoned. The arrest was thought to be due to Steuart's close knowledge of the weakness of the French economy, although another gloss has been put upon the event by Paul Chamley. Chamley indicated that Steuart had been caught in the possession of plans for the invasion of Santo Domingo (Haiti), plans which had been prepared by Mercier de la Rivière, 'who had a personal pecuniary interest in an English invasion of the island and may also have realised that it would do his friend Steuart no harm in the eyes of London if he were arrested by the French' (Chamley 1965: 44-6; Skinner 1998: i.xlv-xlvi).

Steuart returned to England in 1763, the year of peace with France, under the mistaken belief that the British government had acted upon his behalf. Steuart was wrong and did not in fact receive a pardon for past misdemeanours until 1771. But in the meantime he enjoyed the protection of Lord Barrington, sometime Secretary at War, whom he had first met on the foreign tour.

After the frenetic period when he brought the Principles (1767) to completion, he pursued, or rather continued to pursue, work of an academic nature, as the Works amply confirm. He also found time to write a series of letters on the American war (Raynor and Skinner 1994) which are chiefly interesting for his suspicion of military victory and his advocacy of free trade with the colonies whatever the outcome. These letters were written between 1775 and 1778 . 
Steuart was apparently a good neighbour, actively interested in the economic affairs of the locality (Lanarkshire) and in the politics of the region (Skinner 1966: liii-liv). Steuart died on 26 November 1780. He was interred in the family vault at Cambusnethan (Lanarkshire) which is now sadly ruinous. Coltness has been demolished apart from some remnants of the original stable block.

Steuart married Lady Frances Wemyss (Lord Elcho's sister) on 25 October 1743 and their son was born the following year. Sir James SteuartDenham had a distinguished military career. He served mainly in Ireland and on his death in 1839 was the senior general in the British army, notable for his reform of cavalry tactics. He married Alicia Blacker of Carrick but there were no children. (The name Denham was added in 1773 following the transfer of the estate of Westshields to the third Baronet on the death of Archibald Denham.)

\section{The Principles: methodology}

It should be noted that one of the most important features of Sir James Steuart's career was his extensive knowledge of the Continent. The foreign tour (1735-40) and exile as a result of his association with the Jacobites (1745-63) meant that by the end of the Seven Years' War Sir James had spent almost half his life in Europe. In this time he mastered four languages (French, German, Spanish and Italian), a fact which may help to explain Joseph Schumpeter's judgement that 'there is something un-English (which is not merely Scottish) about his views and his mode of presentation' (1954: 176 n.).

In the course of his travels Steuart visited a remarkable number of places which included Antwerp, Avignon, Brussels, Cadiz, Frankfurt, Leyden, Liège, Madrid, Paris, Rome, Rotterdam, Tübingen, Utrecht, Venice and Verona. He seems, moreover, consistently to have pursued experiences which were out of the common way. For example, when he settled at Angoulême he took advantage of his situation to visit Lyons and the surrounding country. During his residence in Tübingen he undertook a tour of the schools in the Duchy of Württemburg. Earlier he had spent no less than fifteen months in Spain, where he was much struck by the irrigation schemes in Valencia, Mercia and Granada, the mosque in Cordoba and the consequences of the famine in Andalousia in the spring of 1737. In fact very little seems to have been lost and it is remarkable how often specific impressions found their way into the main body of the Principles. In his major book Steuart noted the economic consequences of the Seven Years' War in Germany, the state of agriculture in Picardy, the arrangement of the kitchen gardens round Padua and the problem of depopulation in the cities of the Austrian Netherlands.

Steuart drew attention to the difficulties under which he laboured in the preface to the Principles precisely because he thought they would be of 
interest to the reader. He pointed out that the 'composition' was the 'successive labour of many years spent in travelling' (1767: 3-4) during which he had examined different countries 'constantly, with an eye to my own subject':

I have attempted to draw information from every one with whom I have been acquainted: this however I found to be very difficult until I had attained to some previous knowledge of my subject. Such difficulties confirmed to me the justness of Lord Bacon's remark, that he who can draw information by forming proper questions, is already possessed of half the science.

I could form no consistent plan from the various opinions I met with: hence I was engaged to compile the observations I had casually made, in the course of my travels, reading, and experience. From these I formed the following work after expunging the numberless inconsistencies and contradictions which I found had arisen from my separate inquiries.

(Ibid.: 5-6)

Steuart wrote very much in the style of a man finding his way through a new field. This, added to the fact that nearly eight years separate the first and last books, presented obvious problems - problems of which Steuart was always conscious but which he viewed with very mixed feelings:

Had I been master of my subject on setting out, the arrangement of the whole would have been rendered more concise: but had this been the case, I should never had been able to go through the painful deduction which forms the whole chain of my reasoning and upon which ... the conviction it carries along with it in a great measure depends.

(Ibid.: 7)

But the critical point to note is that Steuart attempted to produce a single great conceptual system linking the most interesting branches of modern policy, such as 'population, agriculture, trade, industry, money, coin, interest, circulation, banks, exchange, public credit and taxes' (ibid.: 7, emphasis in original). He added: 'The principles deduced from all these topics appears tolerably consistent; and the whole is a train of reasoning, through which I have adhered to the connection of subjects as faithfully as I could' (ibid.: 7).

Steuart sought to establish a system of thought whose content met the requirements of Newtonian methodology. The leading feature of Steuart's method is objective empiricism. He was thus entirely in accord with Hume, but like Hume he recognised that the mere collection of facts was not of itself sufficient. The first step on the route to knowledge is the col- 
lection and description of facts; the second, the statement of certain "principles' reached through a process of induction.

Steuart also recognised that the scientist can advance only by concerning 'himself' with cause and consequence, that is, by thinking deductively. He solved the problem of how to combine the two techniques by using induction to establish his basic hypotheses, or 'principles', and deduction for what Hasbach described as the 'clarification of phenomena' (1891). Steuart's recommended deployment of the techniques of induction and deduction corresponds closely to Colin MacLaurin's account of the methodology of Sir Isaac Newton, whose 'vast and creative talent' was deeply admired by Steuart (1805: 6, 93). MacLaurin concluded:

It is evident that, as in mathematics, so in natural philosophy, the investigation of difficult things by the method of analysis ought ever to precede the method of composition, or the synthesis. For in any other way we can never be sure that we assume the principles that really obtain in nature; and that our system, after we have composed it with great labour, is not mere dream and illusion.

(MacLaurin 1748: 9, emphasis in original)

Recognition of the necessity of employing both techniques brought awareness of the problem of subjective preference for purely logical thought (Steuart 1767: 6). The problem was widely recognised and the dangers involved often avoided, so that when speaking of the psychological attractions of deductive thought (of which Smith was well aware) Lord Kames (1779: 23) was able to point out that '[i]t rebounds not a little to the honour of some late enquirers after truth that, subduing this bent of nature, they have submitted to the slow and more painful method of experiment'.

Kames did not allude to Steuart, but the latter also recognised the dangers of 'long steps of reasoning' (1767: 19) and deliberately chose a different and more appropriate route to knowledge. Steuart (1805: 2, 121) argued that we should proceed 'by the shortest steps when we draw a conclusion from a general proposition and still keep experience and matter of fact before our eyes'.

Steuart was quite clear as to the techniques of reasoning to be employed. The rules were simple, if difficult to obey: observation, induction, deduction, verification. There remained the question of the technique to be followed in building up a body of knowledge, and here Steuart's answer was equally clear.

The scientist should begin with the simple (and thus apparently abstract) case and gradually take account of more and more complex (and thus 'realistic') cases. The first objective must be clarity and Steuart thus recognised that the attainment of the second, relevance, can come about only through the use of abstraction in the early stages of study. He argued 
that in building up a body of knowledge '[e]very branch of it must, in setting out, be treated with simplicity, and all combinations not absolutely necessary, must be banished from the theory' (Steuart 1767: 227).

But, since the object is relevance, and since the "more extensive any theory be made, the more it will be useful', it follows that as we proceed 'combinations will crowd in and every one of these must be attended to' (ibid.). Steuart always employed this technique in dealing with a body of knowledge; that is, he gradually builds up his argument in a series of steps which progressively increase in complexity.

At the same time, Steuart recognised that theoretical edifices constructed in this manner present the economist with particular difficulties which arise from the nature of the subject matter itself. In Steuart's view, the economist or social scientist can show only 'how consequences may follow from one another: to foretell what must follow is exceedingly difficult, if not impossible' (ibid.: 365, emphasis in original). While we can and must establish general principles these do not provide rules of behaviour which must always hold good. Steuart thus concluded (somewhat ironically, in the context of a critique of Hume's quantity theory) that 'I think I have discovered, that in this, as in every other part of political economy, there is hardly such a thing as a general rule to be laid down' (ibid.: 339).

The procedures which Steuart recommended, and his concern with the problem of prediction, correspond closely with Alfred Marshall's classic statement which was offered more than a hundred years later (1890: Book I, ch. 3; appendices C and D).

Given the need for a systematic statement of particular principles, established in accordance with the discipline of an appropriate methodology, there remained the problem of establishing a useful 'method' in respect of the organisation of the discourse as a whole.

The next thing to be done, is to fall upon a distinct method ... by contriving a train of ideas, which may be directed towards every part of the plan, and which, at the same time, may be made to arise methodically from one another.

(Ibid.: 28)

Here again, Steuart followed Hume's lead.

The 'plan' is contained in the first two books and is based upon a theory of economic development. Steuart's dominant theme was to be change and growth, and it is this which gives his work cohesion:

By this kind of historical clue, I shall conduct myself through the great avenues of this extensive labyrinth; and in my review of every particular district, I shall step from consequence to consequence, until I have penetrated into the inmost recesses of my own understanding. 


\section{The historical perspective}

Steuart clearly accepted a proposition which had been stated by Aristotle (Politics: I, 125a) to the effect that '[i]f you consider the state - or anything else for that matter - in relation to the origins from which it springs, you will arrive at the clearest understanding of its nature'. Steuart thus opened his analysis with 'society in the cradle' before going on to trace the origins of, and the process of transition between, the various stages of the progress of man.

In this context, Steuart made use of a theory of stages, now recognised as a piece of apparatus which was central to the work of the Scottish historical school. He cites, for example, the Tartars and Indians as relatively primitive socio-economic types of organisation (Steuart 1767: 56) while concentrating primarily on the third and fourth stages - the stages of agriculture and commerce. In the former case, Steuart observed that those who lacked the means of subsistence could acquire it only through becoming dependent on those who owned it; in the latter, he noted that the situation was radically different in that all goods and services command a price. He concluded, in passages of quite striking clarity:

I deduce the origin of the great subordination under the feudal government, from the necessary dependence of the lower classes for their subsistence. They consumed the produce of the land, as the price of their subordination, not as the reward of their industry in making it produce.

I deduce modern liberty from the independence of the same classes, by the introduction of industry, and circulation of an adequate equivalent for every service.

(Ibid.: 208-9)

Steuart was also aware of the political aspect of these changes, and its effect upon the state:

From feudal and military, it is become free and commercial. I oppose freedom in government to the feudal system, to mark only that there is not found now that chain of subordination among the subjects, which made the essential part of the feudal form.... I oppose commercial to military; because the military governments now are made to subsist from the consequences and effects of commerce only; that is, from the revenue of the state, proceeding from taxes. Formerly, every thing was brought about by numbers; now, numbers of men cannot be kept together without money.

(Ibid.: 24)

Steuart noted that the gradual emergence of the stage of commerce had generated new sources of wealth which had affected the position of 
princes. 'The prerogative of princes in former times, was measured by the power they could constitutionally exercise over the persons of their subjects; that of modern princes, by the power they have over their purse' (ibid.: 290, emphasis in original).

Steuart also observed that 'an opulent, bold, and spirited people, having the fund of the Prince's wealth in their own hands, have it also in their own power, when it becomes strongly their inclination, to shake off his authority' (ibid.: 216).

The alteration in the distribution of power which was reflected in the changing balance between proprietor and merchant led Steuart to the conclusion that 'industry must give wealth and wealth will give power' (ibid.: 213, emphasis in original). As an earnest of this position, he drew attention (significantly in his Notes on Hume's History) to the reduced position of the Crown at the end of the reign of Elizabeth: a revolution which appears 'quite natural when we set before us the causes which occasioned it. Wealth must give power; and industry, in a country of luxury, will throw it into the hands of the Commons' (ibid.: 213 n.).

It was perhaps for this reason that Steuart's French translator, de Senovert (1789), advised his readers that of the advantages to be gained from a reading of the Principles, '[1] e premier sera de convaincre, sans doute, que la révolution qui s'opère sous nos yeux était dans l'ordre des choses nécessaires' ${ }^{\prime 4}$ (as quoted in Steuart 1767: 24 n. 8). De Senovert in short was convinced of the inevitability of the Revolution and believed that the Principles confirmed the point.

\section{The theory of population}

The analysis of the emergence of the exchange economy is not untypical of the period and intrinsically interesting even if Steuart did consider that it was more properly the province of the science of politics than that of political economy strictly defined. But he also argued that the subjects reviewed above were not 'altogether foreign to this' science, i.e. to economics (ibid.: 206), illustrating the truth of the remark by deploying the 'stadial' thesis in a purely economic context. The technique finds illustration in a number of fields, and generally involves the use of the stages of society treated as models.

The first analytical problem to which Steuart addressed himself, again following Hume, was that of population, where his stated purpose was 'not to inquire what numbers of people were found upon the earth at a certain time, but to examine the natural and rational causes of multiplication' (ibid.: 31). In so doing, he stated that the 'fundamental principle' is 'generation; the next is food' (ibid.), from which it follows that where men live by gathering the spontaneous fruits of the soil (the North American Indian model), population levels must be determined by their extent: 
From what has been said, we may conclude, that the numbers of mankind must depend upon the quantity of food produced by the earth for their nourishment; from which, as a corollary may be drawn. That mankind have been, as to numbers, and must ever be, in proportion to the food produced; and that the food produced will be in the compound proportion of the fertility of the climate, and the industry of the inhabitants.

(Ibid.: 36-7)

Where some effort is applied to the cultivation of the soil (the agrarian stage), Steuart recognised, the output of food and therefore the level of population would grow. But here again he drew a distinction between cultivation for subsistence, which was typical of the feudal stage, and the application of industry to the soil as found in the modern situation, where goods and services command a price, and where the potential for economic growth (and therefore population) is greatly enhanced.

Perhaps two major points arising from this argument deserve further notice. To begin with, attention should be drawn to the emphasis which Steuart gives to the interdependent state of the sectors in his model of the exchange economy, recognising as he did that 'Agriculture among a free people will augment population, in proportion only as the necessitous are put in a situation to purchase subsistence with their labour' (ibid.: 40, emphasis in original). Second, Steuart gave a good deal of attention to the point that the whole process depended on 'reciprocal' wants so that there are cases where the limited extent of the latter will constrain economic development and population growth:

Experience every where shews the possible existence of such a case, since no country in Europe is cultivated to the utmost: and that there are many still, where cultivation, and consequently multiplication, is at a stop. These nations I consider as being in a moral incapacity of multiplying: the incapacity would be physical, if there was any actual impossibility of their procuring an augmentation of food by any means whatsoever.

(Ibid.: 42, emphasis in original)

Although we cannot review the theory in any detail here, it can be said that in Book I we confront a single major theme, the theory of population: a theory which while owing a great deal to David Hume (and possibly to Cantillon) none the less represents some of Steuart's most distinguished contributions and one of the best examples of his capacity for the systematic deployment of diminishing levels of abstraction. The theory also moved Marx to claim that Steuart should be regarded as a major precursor of Malthus (Eltis 1987: 495). But equally characteristic of his mode of argument is the fact that the theory was built up in such a way as to permit 
him to provide an account of the modern or exchange economy (the last of the 'models' used above), thus gradually widening the scope of the enquiry while still preserving a coherent 'chain of ideas'.

\section{The exchange economy}

In dealing with the nature of the exchange economy, it is significant that Steuart made little use of the division of labour in the Smithian sense of the term. On the other hand, he gave great emphasis to the social division of labour in using the basic sectoral division to be found in Cantillon, Hume, Hutcheson, Mirabeau and Quesnay's Encyclopedie articles:

$[\mathrm{W}] \mathrm{e}$ find the people distributed into two classes. The first is that of the farmers who produce the subsistence, and who are necessarily employed in this branch of business; the other I shall call free hands; because their occupation being to procure themselves subsistence out of the superfluity of the farmers, and by a labour adapted to the wants of the society, may vary according to these wants, and these again according to the spirit of the times.

(Ibid.: 43, emphasis in original)

In both cases productive activity involves what Steuart defines as industry, namely 'the application to ingenious labour in a free man, in order to procure, by means of trade, an equivalent, fit for supplying every want'. Trade, on the other hand, is defined as:

an operation by which the wealth, or work, either of individuals, or of societies, may, by a set of men called merchants, be exchanged, for an equivalent, proper for supplying every want, without any interruption to industry, or any check upon consumption.

(Ibid.: 146, emphasis in original)

The whole pattern is carried on through the use of money, also defined, with characteristic care, as:

any commodity, which purely in itself is of no material use to man. . but which acquires such an estimation from his opinion of it, as to become the universal measure of what is called value, and an adequate equivalent for anything alienable.

(Ibid.: 44, emphasis in original)

For Steuart the modern system was clearly an exchange economy characterised by a high degree of dependence between forms of activity and the individuals who carried them on, so that the idea or ideal of a free society emerges as involving ' a general tacit contract, from which reciprocal and 
proportional services result universally between all those who compose it' (ibid.: 88, emphasis in original). Later Steuart was to state a hypothesis of obvious relevance to the situation under review in remarking that:

[t]he principle of self-interest will serve as a general key to this inquiry; and it may, in one sense, be considered as the ruling principle of my subject, and may therefore be traced throughout the whole. This is the main spring....

(Ibid.: 142)

But the main underlying theme remains that of the interdependence of economic phenomena, a theme which brought Steuart quite logically to the treatment of price and allocation.

As far as the supply price of commodities is concerned, Steuart noted two elements: 'to wit, the real value of the commodity, and the profit upon alienation'. Real value was defined in such a way as to include three elements:

The first thing to be known of any manufacture when it comes to be sold, is, how much of it a person can perform in a day, a week, a month, according to the nature of the work, which may require more or less time to bring it to perfection...

The second thing to be known, is the value of the workman's subsistence and necessary expense, both for supplying his personal wants, and providing the instruments belonging to his profession, which must be taken upon an average as above...

The third and last thing to be known is the value of the materials, that is the first matter employed by the workman...

These three articles being known, the price of the manufacture is determined. It cannot be lower than the amount of all the three, that is, than the real value; whatever it is higher, is the manufacturer's profit.

(Ibid.: 160-1)

He went on to note that:

when we say that the balance between work and demand is to be sustained in equilibrio, as far as possible, we mean that the quantity supplied should be in proportion to the quantity demanded, that is, wanted. While the balance stands justly poised, prices are found in the adequate proportion of the real expence of making the goods, with a small addition for profit to the manufacturer and merchant.

(Ibid.: 189, emphasis in original) 
As far as the process of price determination was concerned, Steuart contended that the outcome of the 'contract' would be determined by competition between and among buyers and sellers. 'Double competition is, when, in a certain degree, it takes place on both sides of the contract at once, or vibrates alternately from one to the other. This is what restrains prices to the adequate value of the merchandize' (ibid.: 172, emphasis in original).

Thus, for example, if there is a relative shortage of some commodity there may be competition between buyers in order to procure limited supplies, thus causing prices to rise. In the event of an excess supply, e.g. of a perishable commodity such as fish, there will be competition between sellers to rid themselves of excess stocks, thus causing prices to fall below their equilibrium values. Both cases present examples of what Steuart called 'simple competition' prevailing in effect on one side of the 'contract only', and anticipated Smith's position.

Three points follow from this argument. First, the attainment of a 'balance' between demand and supply does not of itself indicate a position of equilibrium; and, second, that the process of bargaining will normally affect both parties to the exchange:

In all markets ... this competition is varying, though insensibly, on many occasions; but in others, the vibrations are very perceptible. Sometimes it is found strongest on the side of the buyers, and in proportion as this grows, the competition between the sellers diminishes. When the competition between the former has raised prices to a certain standard, it comes to stop; then the competition changes sides, and takes place among the sellers, eager to profit of the highest price. This makes prices fall, and according as they fall, the competition between the buyers diminishes.

(Ibid.: 174)

Steuart was thus able to offer a definition of equilibrium but also a statement of a stability condition in noting that ' $[\mathrm{i}] \mathrm{n}$ proportion therefore as the rising of prices can stop demand, or the sinking of prices can increase it, in the same proportion will competition prevent either the rise or the fall from being carried beyond a certain length' (ibid.: 177).

Finally, it should be noted that Steuart was aware of the allocative functions of the market. As he put it:

Trade produces many excellent advantages; it marks out to the manufacturers when their branch is under or overstocked with hands. If it be understocked, they will find more demand than they can answer: if it be overstocked, the sale will be slow.

(Ibid.: 158) 
Arguments such as these are obviously broadly 'static' in character but in fact are to be found in a setting which shows the same preoccupation with the long-run dynamics which characterise the argument of the first book, thus presenting the reader with yet another change of focus, this kind of a macroeconomic type.

It will be recalled that Steuart's definition of equilibrium required that the balance between supply and demand be such that "prices are found in the adequate proportion of the real expense of making the goods, with a small addition for profit to the manufacturer or merchant'. It was Steuart's view that this definition, originally applied to particular commodities, must also apply to all goods, thus suggesting, as in the case of Smith's Lectures, an intuitive grasp of the general interdependence of economic phenomena. Indeed, this perspective seems to dominate Steuart's treatment of the long run, where he argues in effect that the balance of work and demand, taking the economy as a macro unit, is likely to change over time, with consequent effects on the components of real value and on the relationship between real value and price.

Some causes of change, while important, were easily explained. Steuart recognised that taxes, for example, could affect the prices of commodities. He also drew attention to the tendency for the prices of primary products (subsistence and materials) to rise over time, especially as a result of 'the increase of population, which may imply a more expensive improvement of the soil' (ibid.: 198). But the most significant problem, for Steuart, was located on the demand side.

Steuart believed that the long-run macroeconomic trend would be for the balance of demand to preponderate initially, generating higher levels of profit, and thus suggesting a tendency for the general price level to rise over time. But he added that the impact on the general price level would be reinforced by another factor: higher profits 'subsisting for a long time ... insensibly become consolidated, or, as it were, transformed into the intrinsic value of the goods' (ibid.: 193, emphasis in original) in such a way as to become 'in a manner necessary' to their existence. Second, and related to the above, Steuart distinguished between physical and political necessaries, where the former is defined almost in biological terms as 'ample subsistence where no degree of superfluity is implied' (ibid.: 269, emphasis in original). He added:

The nature of man furnishes him with some desires relative to his wants, which do not proceed from his animal oeconomy, but which are entirely similar to them in their effects. These proceed from the affections of his mind, are formed by habit and education, and when once regularly established, create another kind of necessary, which, for the sake of distinction, I shall call political.

(Ibid.: 270, emphasis in original) 
Steuart went on from this point to suggest that the political necessary was 'determined by birth, education or habit' and 'rank' in society, clearly recognising that it is 'determined by general opinion only, and therefore can never be ascertained justly' (ibid.: 271). But he was clear in respect of one point, namely that there is a tendency for the acceptable definition of the political necessary to rise over time with revised expectations of acceptable standards of living. The importance of this argument was to emerge in a later stage of the exposition.

But for the moment, the important point to note is that the theses just outlined provide one reflection of Steuart's confidence in respect of the potential for economic growth, which was essentially demand-led.

In addressing himself to the modern state in particular, Steuart drew attention to the 'extraordinary flux of money' (ibid.: 309) and to the fact that its institutions had greatly stimulated that 'taste for superfluity and expence' (ibid.: 243) which was associated with 'luxury' in its modern or 'systematical' form; a point which he (like Hume) thought to be of greater significance than the discovery of the mines of the New World.

The general point at issue is best caught by Steuart's earlier (but recurring) contrast between the feudal and modern systems. 'Men were then forced to labour because they were slaves to others; men are now forced to labour because they are slaves to their own wants' (ibid.: 51, emphasis in original).

In the manner of Smith and Hume, it was Steuart's contention that the modern economy had opened up new forms of demand and new incentives to industry. In passages reminiscent of Smith's Moral Sentiments (which he may have read), Steuart drew attention to man's love of ingenuity and to the fact that the satisfaction of one level of perceived wants tends to open up others, by virtue of a kind of 'demonstration' effect (ibid.: 157, cf. Smith 1759: IV.1).

But Steuart also paid attention to the supply side in this connection, suggesting that refinements of taste:

seem more generally owing to the industry and inventions of the manufacturers (who by their ingenuity daily contrive means of softening or relieving inconveniences, which mankind seldom perceive to be such, till the way of removing them be contrived) than to the taste for luxury in the rich, who, to indulge their ease, engage the poor to become industrious.... Here then is a reason why mankind labour though not in want. They become desirous of possessing the very instruments of luxury, which their avarice or ambition prompted them to invent for the use of others.

(Steuart 1767: 157)

As Hume had already pointed out, the institutions of the exchange economy also provided an important stimulus to economic activity in the sense that these institutions had established a situation where " $[w]$ ealth 
becomes equably distributed ... by equably distributed I do not mean, that every individual comes to have an equal share, but an equal chance, I may say a certainty, of becoming rich in proportion to his industry' (Steuart 1805: 2, 156, emphasis in original).

Steuart also argued that the potential for economic growth was almost without limit or certain boundary in the current 'situation of every country in Europe' -especially France, 'at present, ... in her infancy as to improvement, although the advances she has made within a century excite the admiration of the world' (Steuart 1767: 137). An equally dramatic confirmation of the general theme is to be found in the chapter on machines, which he considered to be 'of the greatest utility' in 'augmenting the produce or assisting the labour and ingenuity of man' (ibid.: 123).

He added:

Upon the whole, daily experience shews the advantage and improvement acquired by the introduction of machines. Let the inconveniences complained of be ever so sensibly felt, let a statesman be ever so careless in relieving those who are forced to be idle, all these inconveniences are only temporary; the advantage is permanent, and the necessity of introducing every method of abridging labour and expence, in order to supply the wants of luxurious mankind, is absolutely indispensable, according to modern policy, according to experience, and according to reason.

(Ibid.: 125)

Steuart's confidence in the potential for economic growth was further supported by his appreciation of the opportunities presented by international trade.

\section{Development and trade}

Steuart recognised that trade within and between states would immeasurably increase the possibilities of economic growth through the provision of wider markets. He was thus able to conclude that 'trade has an evident tendency towards the improvement of the world in general' (ibid.: 119).

He recognised further that trade between nations, like that between men, was based upon the existence of reciprocal needs, so that the cement of international society, like that of civil society, must be of the same kind: "intercourse tends to unite the most distant nations as well as to improve them: and ... their mutual interest leads them to endeavour to become serviceable to one another' (Steuart 1805: 2.217). Elsewhere Steuart (1767: 231) noted that '[t]rade, therefore, and foreign communications, form a new kind of society among nations' - thus making the task of the 'statesman' more complex.

In the second book Steuart dropped the assumption of the closed 
economy. Characteristically, he traced the interrelationship of developed and undeveloped nations in terms of the distinction between active and passive trade, which had already been established by Malachy Postlethwayt (cf. Johnson 1937: 224). Here the purpose was to examine the positive impact of foreign demand on a backward economy in terms of an analysis which anticipated one of Adam Smith's most notable disciples, J. B. Say, who in effect elaborated an argument which is developed, albeit in a purely historical context, in Book III of the Wealth of Nations (Smith 1776).

Equally striking is the fact that Steuart treated different states as competitive firms:

The trading nations of Europe represent a fleet of ships, every one striving who shall get first to a certain port. The statesman of each is the master. The same wind blows upon all; and this wind is the principle of self-interest, which engages every consumer to seek the cheapest and the best market. No trade wind can be more general, or more constant than this.

(Steuart 1767: 203)

But Steuart's treatment of international trade takes as its basic premise the proposition that economic conditions and performance will differ even in the context of the relatively developed nations whose trade he described as 'active'.

He was clearly aware of variations caused by 'natural advantages' such as access to materials, transport and the nature of the climate (ibid.: 238), as befits a close student and admirer of 'the great' Montesquieu (ibid.). To these he added the form of government in arguing that 'trade and industry have been found mostly to flourish under the republican form, and under those which have come nearest to it' (ibid.: 211). But equally important for Steuart were the spirit of a people and 'the greater degree of force' with which 'a taste for refinement and luxury in the rich, an ambition to become so, and an application to labour and ingenuity in the lower classes of men' manifested themselves in different societies at any one point in time and over time.

He also believed that there are likely to be variations in the extent to which the definition of 'political necessary' changes through time and in the rate and extent to which the 'balance' of demand tends to preponderate in different countries. Steuart was acutely conscious of the sheer variety of economic conditions and indeed noted early in the book that:

[i]f one considers the variety which is found in different countries, in the distribution of property, subordination of classes, genius of people, proceeding from the variety of forms of government, laws, climate, and manners, one may conclude, that the political oeconomy of each must necessarily be different. 
From the point of view of policy, the number of possible 'combinations' opened up by the proposition that growth rates and other characteristics will vary is virtually endless, and it was in recognition of this point that Steuart employed three broad classifications, all of which may derive from Mirabeau's Friend of Man (1756) but which generalise on the argument already advanced by Hume; the stages of infant, foreign, and inland trade.

Infant trade represents that situation 'known in all ages, and in all countries, in a less or a greater degree' and which is antecedent to supplying the wants of others. Here the ruling principle:

is to encourage the manufacturing of every branch of natural productions, by extending the home-consumption of them; by excluding all competition with strangers; by permitting the rise of profits, so far as to promote dexterity and emulation in invention and improvement; by relieving the industrious of their work, as often as demand for it falls short; and, until it can be exported to advantage, it may be exported with loss, at the expence of the public.

(Steuart 1767: 263)

At the same time, Steuart suggested that the statesman must control profit levels so that when the real value of commodities indicates that they are competitive in the international context, trade may begin. In the same vein he argued that while protection is essential if industry is to be established, 'the scaffolding must be taken away when the fabric is completed' (Steuart 1805: 2, 235).

In the case of foreign trade, taken as representing the attainment of a competitive stage, the policies recommended are simply designed to retain the capability: here the ruling principles are:

to banish luxury; to encourage frugality; to fix the lowest standard of prices possible; and to watch, with the greatest attention, over the vibrations of the balance between work and demand. While this is preserved, no internal vice can affect the prosperity of it.

(Steuart 1767: 263)

Inland trade, on the other hand, represents a situation where a developed nation has lost its competitive edge as a result of the tendency for the balance of work and demand to be disturbed in the historical long run. Here the basic preoccupation must once more be the maintenance of the level of employment. Steuart also recognised the importance of the balance of payments in advocating a restrictive monetary policy, and concluded that 'I will not therefore say, that in every case which can be supposed, certain restrictions upon the exportation of bullion or coin are contrary to good policy. This proposition I confine to the flourishing nations of our own time' (ibid.: 581). 
But in this case the basic problem was not the level of aggregate demand so much as the need to keep domestic price levels as low as possible with a view to taking advantage of the present and future difficulties of other states. With the possible exception of Holland, it was Steuart's contention that because all nations would suffer the same long-run trends, but at different rates, it followed that:

as industry and idleness, luxury and frugality, are constantly changing their balance throughout the nations of Europe, able merchants make it their business to inform themselves of these fluctuations, and able statesmen profit of the discovery for the re-establishment of their own commerce.

(Ibid.: 296)

This possibly endless process of competition and of fluctuating fortunes was qualified by Steuart only by reference to the classic eighteenth-century theme of growth and decay; the belief (shared in some form by, among others, Cantillon, Hume and Smith) that:

no trading state has ever been of long duration, after arriving at a certain height of prosperity. We perceive in history the rise, progress, grandeur, and decline of Sydon, Tyre, Carthage, Alexandria, and Venice, not to come nearer home. While these states were on the growing hand, they were powerful; when once they came to their height, they immediately found themselves labouring under their own greatness.

(Ibid.: 195-6)

While it appears that nations may be expected to go through a series of stages of trade, fluctuating especially between the second and third, this should not distract attention from the point that trade takes place between nations at a given point in time where these nations, and industries and regions within them, are differently circumstanced, thus requiring different strategies in a policy sense in respect of all these areas.

\section{The role of the state: domestic policy}

As the argument developed above suggests, there is another side to Steuart's work, namely his preoccupation with economic policy and the role of the statesman. As S. R. Sen and others have frequently pointed out, Steuart was particularly interested in the issue of welfare, with particular regard to the level of employment, for reasons which are entirely consistent with his earlier definition of the exchange economy. Since, as we have seen, this was held to involve 'a general tacit contract from which recipro- 
cal and proportionate services result universally between all those who compose it', it followed that:

Whenever ... any one is found, upon whom nobody depends, and who depends upon every one, as is the case with him who is willing to work for his bread, but who can find no employment, there is a breach of the contract, and an abuse.

(Ibid.: 88)

Where market forces fail, the state must intervene, in Steuart's view, simply because there is no alternative. 'The state of affairs in Europe, and in England in particular, is changed entirely, by the establishment of universal liberty. Our lowest classes are absolutely free; they belong to themselves...' (ibid.: 77).

Once again these are not arguments to which Smith would have taken exception even if the difference in the perspective adopted by the two men is very clear. As Steuart put it:

my point of view is, to investigate how a statesman may turn the circumstances which have produced this new plan of oeconomy to the best advantage for mankind.... My object is to examine the consequences of what we feel and see daily passing, and to point out how far the bad may be avoided, and the good turned to the best advantage.

(Ibid.: 75-6)

He added that:

[i]n treating every question of political oeconomy, I constantly suppose a statesman at the head of government, systematically conducting every part of it, so as to prevent the vicissitudes of manners, and innovations, by their natural and immediate effects or consequences, from hurting any interest within the commonwealth.

(Ibid.: 122)

Looking back on the nature of his contribution, and on the reaction of the reviews of 1767, Steuart was to write that 'I frankly acknowledge, that I have, perhaps, on some occasions, been more apt to consider myself in the light of a political matron, than that of a jovial and free born Englishman' (1805: 4, 392 n.). And yet the role of the 'political matron' was not perhaps inappropriate, given the nature of Steuart's European experience and of the particular scope of the Inquiry. A number of points may be offered by way of illustration.

First, attention should be drawn to Steuart's interest in 'that spirit of liberty, which reigns more and more every day, throughout all the polite 
and flourishing nations of Europe' (Steuart 1767: 18). He was acutely aware of the current 'revolution' in the affairs of Europe: 'Trade and the Industry are in vogue; and their establishment is occasioning a wonderful fermentation with the remaining fierceness of the feudal constitution' (ibid.: 215).

In fact Steuart, notably in Book I of the Principles, directly addressed a problem, which is implicit in the analysis of the third book of the Wealth of Nations, but which was not explicitly considered by Smith: namely, the policy dimension of the socio-economic process which finally resulted in the emergence of the fourth stage of commerce in an advanced form. Steuart's model may be loosely described as that of "primitive accumulation' in contrast to Smith, where 'the process of "primitive accumulation" has now been completed' (Kobayashi 1967: 19). The same point has been made by Perelman in noting that Steuart directly addressed the problems of a primitive version of the stage of commerce (1983: 454) in a way which led Marx to appreciate his sensitivity to historical differences in modes of production (ibid.: 467).

There are, however, other dimensions to Steuart's treatment of this general theme. Steuart may, for example, be seen to have used historical experience as a model on the basis of which advice could be offered to the statesman who actually confronted the economic and social problems involved in emergence from the agrarian stage - a condition which obtained in many countries of Europe at the time of writing (Steuart 1767: 215).

In yet another version of the same argument Steuart suggested that the historical and contemporary record could provide a guide to the problems which would confront a statesman seeking to induce change, i.e. a guide to the statesman who seeks to adopt a conscious policy of economic, and therefore of social, development. It was Steuart's contention that in many cases the transition from a state of 'trifling industry' and subsistence farming would not occur without 'the interposition of the sovereign, and a new plan of administration' (ibid.: 96).

Steuart was undoubtedly preoccupied with the problem of employment in socio-economic systems in a process of transition:

Pipers, blue bonnets, and oat meal, are known in Swabia, Auvergne, Limousin, and Catalonia, as well as in Lochaber: numbers of idle, poor, useless hands, multitudes of children, whom I have found to be fed, nobody knows how, doing nothing at the age of fourteen ... If you ask why they are not employed, their parents will tell you because commerce is not in the country: they talk of commerce as if it was a man, who comes to reside in some countries in order to feed the inhabitants. The truth is, it is not the fault of these poor people, but of those whose business it is to find out employment for them.

(Ibid.: 108) 
Second, and arising from the above, it is worth noting Steuart's interest in the problem of regional imbalance even within the context of a relatively mature economy.

Steuart's general interest in regional issues is a marked feature of the Principles and was to find further expressions in his Considerations of the Interest of the County of Lanark in Scotland, which was published in 1769 under the name of Robert Frame. This short work was explicitly designed to illustrate general principles by reference to a particular case; namely that of a backward county in which Steuart resided and which supplied corn to the neighbouring city of Glasgow. Steuart was concerned to demonstrate the impact of the city's demand for agricultural produce on an undeveloped region (1805: 5, 321). He also drew attention to the fact that economic development had enhanced local demand, and thus temporarily reduced the supply of food available for sale outwith the region.

From the point of view of the city, the fact that local supply was fitful had lent support to the proposed Forth and Clyde Canal, which was intended to link the two coasts and further to improve the market for grain. Steuart clearly welcomed this development, while warning his contemporaries that its short-run effect would be to ruin local agriculture unless steps were taken to further the cause of agricultural improvement and to develop the local infrastructure. In particular he contended that the infant industry argument as developed in his treatment of 'infant trade', and which had been applied to the textiles of the neighbouring town of Paisley, should be extended to agriculture (ibid.: 5, 308). He also advocated high and stable prices for agricultural produce, while calling for a granary scheme which would in effect secure supplies and stabilise incomes at a level which was consistent with improvement (cf. Eltis, 1986: 44).

Steuart returned to this theme in the course of the Corn Law debate of the 1770s. He objected to the view of the Glasgow merchants that the proposed reduction in the importation price would not necessarily reduce costs, as they suggested, and that it would certainly further discourage local agriculture. Interestingly, Steuart objected to the merchants' reliance on Smith's authority (as distinct from Smith's general position) on the ground that it was at worst politically motivated and at best failed to distinguish between a general principle and a particular application. 'I have had conversations with the Glasgow Theorists. I have written to them on the same subject, to no purpose' (ibid.: 6, 379; see Skinner 1966: liv-lv).

Third, and leading on from the previous point, Steuart was deeply preoccupied by the belief that even where markets were relatively well organised, there was always a tendency for them to fail - hence the emphasis on the constant need for the 'statesman' to supervise their operation and to maintain the balance of work and demand in particular cases as well as in a macroeconomic context. But this is a legitimate alternative to Smith's 
view in the context of the eighteenth century and one which again recalls Schumpeter's judgement with regard to von Justi:

His laisser-faire policy was laisser-faire plus watchfulness, his private enterprise economy a machine that was logically automatic but exposed to breakdown and hitches which his government was to stand ready to mend ... his vision of economic policy might look like laisserfaire with the nonsense left out.

(Schumpeter 1954: 172)

These contrasting positions provide a classic example of a modern dilemma, that is, the problem of identifying when markets have failed. To intervene too soon presents the risk of distortion; to intervene too late runs the risk of incurring unacceptable social and economic costs.

This broad perspective is also particularly obvious in Steuart's treatment of international trade, where, as we have seen, he offered a generalised statement of Hume's rich country-poor country thesis in producing his version of Mirabeau's three distinct stages of trade - each with its appropriate policy recommendations. The basic problem reflects Steuart's understanding of the fact that a variety of conditions must prevail. As he put it:

Were industry and frugality found to prevail equally in every part of these great political bodies, or were luxury and superfluous consumption every where carried to the same height, trade might, without any hurt, be thrown entirely open. It would then cease to be an object of a statesman's care and concern.

(Steuart 1767: 296)

Given the circumstances outlined, there is a certain realism in Steuart's general conclusion:

Nothing, I imagine, but an universal monarchy, governed by the same laws, and administered according to one plan well concerted, can be compatible with an universally open trade. While there are different states, there must be different interests; and when no one statesman is found at the head of these interests, there can be no such thing as a common good; and where there is no common good, every interest must be considered separately.

(Ibid.: 365)

\section{Instruments and constraints}

If most of the problems just considered can be said to be associated with the exchange economy, then so too were the means of implementing the 
appropriate policies. In this connection Steuart drew attention to the role of the public debt, while giving particular emphasis to the fact that 'by the imposition of taxes, and the right employment of the amount of them, a statesman has it in his power to retard or to promote the consumption of any branch of industry' (ibid.: 332). Steuart also drew attention to the rate of interest as an instrument of economy policy (ibid.: 462) and to the statesman's capacity to manipulate the money supply, concluding that 'he':

ought at all times to maintain a just proportion between the produce of industry, and the quantity of circulating equivalent, in the hands of his subjects, for the purchase of it; that, by a steady and judicious administration, he may have it in his power at all times, either to check prodigality and hurtful luxury, or to extend industry and domestic consumption, according as the circumstances of his people shall require the one or the other corrective... . For this purpose he must examine the situation of his country, relatively to three objects, viz. the propensity of the rich to consume; the disposition of the poor to be industrious; and the proportion of circulating money, with respect to the one and the other.

(Ibid.: 323-4, emphasis in original)

In passages reminiscent of Hume, Steuart argued that the modern statesman, by virtue of his capacity to manipulate taxation, public debt, monetary and fiscal policy, had at his disposal greater sources of power than in any previous age. He added that the modern citizen was in a sense much more constrained than his predecessors:

Can any change be greater among free men, than from a state of absolute liberty and independency to become subject to constraint in the most trivial actions? This change has however taken place over all Europe within these three hundred years, and yet we think ourselves more free than ever our fathers were.

(Ibid.: 26)

Later he was to remark:

So powerful an influence over the operations of a whole people, vests an authority in a modern statesman, which in former ages, even under the most absolute governments, was utterly unknown. The truth of this remark will appear upon reflecting on the force of some states, at present in Europe, where the sovereign power is extremely limited, in every arbitrary exercise of it, and where, at the same time, it is found to operate over the wealth of the inhabitants, in a manner far more efficacious than the most despotic and arbitrary authority possibly can do.

(Ibid.: 278, emphasis in original) 
But in practice, Steuart gave a great deal of emphasis to the constraints confronting the statesman, in drawing attention, much as Smith had done, to the importance of the 'spirit' of a people as 'formed upon a set of received opinions relative to three objects: morals, government, and manners' (ibid.: 22) - opinions of such significance 'that many examples may be found, of a people's rejecting the most beneficial institutions, and even the greatest favours, merely because some circumstance had shocked their established customs' (ibid.: 27). Linked to the above, but separate from it, was Steuart's concern with the subjects' imperfect knowledge of the purposes of particular policies - indeed, he pointed out in the preface that although the work may 'seem addressed to a statesman, the real object of the inquiry is to influence the spirit of those whom he governs' (ibid.: 12). He went on to note that 'A people taught to expect from a statesman the execution of plans, big with impossibility and contradiction, will remain discontented under the government of the best of Kings' (ibid.: 13).

To such constraints must be added those of a broadly constitutional kind in that the major sources of modern power (for example, public debt and taxes) have to be sensitively applied if they are not to be counterproductive. Steuart also noted that the advent of the modern economy had led to a shift in the balance of political power. While recognising, as Smith was to do, that the institutions of the commercial stage are compatible with both republican and monarchical forms, he observed that he knew of 'no christian monarchy (except, perhaps, Russia) where either the consent of states, or the approbation or concurrence of some political body within the state, has not been requisite to make the imposition of taxes constitutional' (ibid.: 290).

But perhaps the most important element in what A. O. Hirschman has described as Steuart's 'deterrence model' of government is the emphasis given to the role of purely economic laws. For Steuart, the statesman 'is neither master to establish what oeconomy he pleases, or, in the exercise of his sublime authority, to overturn at will the established laws of it, let him be the most despotic monarch upon earth' (ibid.: 16). Later he wrote:

The power of a modern prince, let it be by the constitution of his kingdom, ever so absolute, immediately becomes limited so soon as he established the plan of oeconomy which we are endeavouring to explain. If his authority formerly resembled the solidity and the force of the wedge ... it will at length come to resemble the delicacy of the watch, which is good for no other purpose than to mark the progression of time, and which is immediately destroyed, if put to any other use, or touched with any but the gentlest hand.

As modern oeconomy ... is the most effectual bridle ever ... invented against the folly of despotism; so the wisdom of so great a 
power never shines with greater lustre, than when we see it exerted in planning and establishing this oeconomy, as a bridle against the wanton exercise of itself in succeeding generations.

(Ibid.: 278-9)

Earlier in the work he remarked that:

When once a state begins to subsist by the consequences of industry, there is less danger to be apprehended from the power of the sovereign. The mechanism of his administration becomes more complex, and ... he finds himself so bound up by the laws of his political oeconomy, that every transgression of them runs him into new difficulties.

(Ibid.: 217)

This point did not go unnoticed.

When the Principles was reviewed in 1767, it was in the main criticised for the role ascribed to the statesman. The point was repeated in the reviews of Steuart's Works (1805), when the Monthly complained that the author had committed a 'capital and injurious mistake' when insisting on the 'statesman's constant superintendence over trade'. Yet the same reviewer perceptively remarked that:

a reader of the present day will most prize, in these volumes, their illustration of the influence of political economy on civil government: which places in the strongest light the mischiefs of arbitrary rule, and which exhibit it as not less prejudicial to its depositaries than to their subjects. This very momentous question, is no where, to our knowledge, so satisfactory treated.

(Monthly Review 1806: 50; 115)

The reviewer of the Playfair edition of the Wealth of Nations in the same journal noted that:

Wide as have been the excursions of Dr Smith into politics and statistics, he never discussed the influence of the true principles of political economy over civil government. This fine subject, however, has been treated by Sir James Steuart with considerable success.

(Monthly Review 50: 123)

But it is equally important to remember that in referring to the statesman Steuart was not speaking of 'minister of state, and even such as are eminent for their knowledge in state affairs', nor yet of a particular type of government. As he put it, within the context of the Principles, 'the statesman' is taken to be a 'general term to signify the legislature and supreme power, according to the form of government' (ibid.: 16). Moreover, we 
should note that Steuart abstracted from those particular constraints which arise from the nature of the monarch, or from the types of political pressures to which a legislature might be subject. In sharp contrast to the position adopted by Smith, Steuart spoke only:

of governments only which are conducted systematically, constitutionally, and by general laws; and when I mention princes, I mean their councils. The principles I am enquiring into, regard the cool administration of their government; it belongs to another branch of politics, to contrive bulwarks against their passions, vices and weaknesses, as men.

(Ibid.: 217)

\section{Conclusion}

Steuart's statesman is essentially an abstract concept. Ironically, Smith, with his greater emphasis on the role of the market, took a different, and politically more informative view, in emphasising the significance of pressure groups and, in particular, of mercantile pressure groups, as they affect public policy. But the absence of a political dimension, in the sense in which Smith used the term, also means that his 'very violent attack' upon this aspect of the mercantile system finds no target in the Principles, nor, perhaps, as many other direct targets as is sometimes thought.

From an analytical point of view, Steuart's Principles does not compare with Smith's great conceptual system which had so profound an influence on the classical account. Even those writers who have quite properly emphasised the agrarian dimension to Smith's thought (e.g. McNally) do not deny that the components and structure of the analytical system found continuing relevance under very different economic conditions as compared with those which actually confronted Smith (cf. Skinner 1996: ch. 7).

But this is not to deny that Steuart's perception of relevant areas of economic policy in the eighteenth century was misplaced in his time, or indeed in any other time where the conditions which he confronted are replicated. Steuart's complex views on economic policy serve to remind us of the wide range of practical problems which Smith's analytical strategy caused him to ignore, thus adding to our appreciation of the content of that strategy. The same perspective also reminds us of Schumpeter's belief that economic policy must reflect the conditions which are perceived to prevail (local, national and international) and of his legitimate doubts with respect to practical principles, such as freedom of trade, which claim universal validity. When we add Steuart's sensitivity to the problem of method and prediction, we gain some idea of the complexity of the subject which Steuart addressed. It was for these reasons that Terence Hutchison (1988: 350) concluded that Steuart's stylistic faults were 
'brought about by his intellectual virtues, and by his persistent resistance to oversimplification ... It is easier to write clearly and engagingly when one has a simple system to expound'. Smith may well have ignored the Principles, when he came to write the Wealth of Nations, because there were limited points of contact between two such different systems. As Johnson (1937: 210) remarked in reviewing the content of Steuart's work, 'Smith would have had real difficulty in refuting completely a system of economic theory which contained so many elements. Very wisely he rejected the challenge.'

It should also be emphasised that while Smith and others gathered information concerning remote peoples as part of the exercise of establishing a complete history of civil society, Steuart exploited an unexpected opportunity with regard to contemporary Europe which was quite unique and unmatched by any Scottish thinker of the time. In the course of his travels he visited, as we have seen, a number of places which would be remarkable even by modern standards and which is quite astonishing given the problems of communication which prevailed.

It is thus scarcely surprising, in view of the differing analytical contributions, that Dugald Stewart (1857: ix, 458) should have recommended his students to begin their study of political economy by reading the Wealth of Nations and then to proceed to the Principles as a work which contained 'a great mass of accurate details' gleaned through 'personal observation during a long residence on the Continent'. Stewart may also have intended his students to appreciate that Steuart's stance was Eurocentric rather than Anglocentric in character.

Steuart was surely a worthy contributor to what he himself described as an 'Augustan age' (Steuart 1767: 6). But Donald Winch has remarked with respect to the Principles that 'the difficulties in making this part of Smith's context are well known. To put it bluntly, one has to take on board a Jacobite traitor tainted with Continental notions' (Winch 1983: 268).

There is no doubt that Steuart threw in his lot with the Cause, nor that his political ambitions, thwarted by the influential Arniston family, as he thought, prompted this action. As Elizabeth Mure remarked:

I look on this as the foundation of all his after conduct, for had that revolution taken place which he wished, he would have been the first man in the state. When their Prince was at Edr he was consulted in everything, he wrote the Manifesto, and several little things in the public papers, and was sent as ambassador to France to negotiate assistance.

(Chamley 1965: 116)

Committed Jacobite he may have been, but a man 'tainted with Continental notions'? This judgement echoes comments made by the review of 1767, which accused Steuart of 'imbibing prejudices abroad by no means 
consistent with the present state of England, and the genius of Englishmen' (Monthly Review 36, 1767: 464).

Steuart replied, with a logic more attractive, perhaps, to a later age:

Can it be supposed, that during an absence of near twenty years, I should in my studies, have all the while been modelling my speculations upon the standard of English notions.... If, from this work, I have any merit at all, it is by divesting myself of English notions, so far as to be able to expose in a fair light, the sentiments and policy of foreign nations, relative to their own situation.

(Steuart 1767: 4-5)

Scottish students of Montesquieu would surely have admired the sentiment at least.

Yet the work was not greatly admired in Scotland, at least among some. In a letter to Hume, for example, Hugh Blair (1767) described the Principles as 'the most ponderous lumber that I have ever looked into'. Hume himself was critical of the 'form and style' of the work (Skinner 1966: xlv) while Smith is known to have avoided any reference to the Principles even where it might have been expected that he might have done so, such as the treatment of the Bank of Amsterdam. It is also known that Smith wrote to William Pulteney on 4 September 1772 to the effect that 'I have the same opinion of Sir James Stewart's [sic] book that you have. Without once mentioning it, I flatter myself, that every false principle in it will meet with a clear and distinct confutation in mine' (Smith 1987: letter 132). The statement may be ambiguous but the overwhelming impression to be derived from all these comments is negative.

But if Steuart did not fare well among at least some of the key figures of the Enlightenment the situation was rather different upon the Continent and elsewhere. During the 1770s the text was twice translated into German, while there was a French version in 1789. Kobayashi (1967) has suggested that Steuart's model of 'primitive accumulation' may help to explain the popularity of his work among his contemporaries in Ireland and Germany. Keith Tribe (1988: 133) on the other hand, noted that 'until the final decade of the eighteenth century Sir James Steuart's Inquiry was better known and more frequently cited than Smith's Wealth of Nations'.

But perhaps the most intriguing link is with North America. The pirated Dublin edition of 1770 circulated widely in the colonies and attracted the attention of Alexander Hamilton, who was naturally concerned about the economic prospects of the infant republic. Hamilton rejected Smith's 'fuzzy philosophy' in favour of a policy of protection as a means of counterbalancing the competitive advantages of the British economy in the years following the Peace of Paris (1783). This perspective seems to have been widely shared, and is essentially a variant of Steuart's stage of 'infant trade'. 


\section{Notes}

1 The analysis of Steuart's system is based upon Skinner $(1966,1981,1988)$. The chapter includes extracts from chapter 11, 'Sir James Steuart: Principles of Political Economy', from A System of Social Science (1996) by Skinner, Andrew Stewart, by permission of Oxford University Press. All references to the text are from the 1966 edition, unless otherwise noted. They are given in the form '1767:000'.

2 Details of the family history are given in the Coltness Collections 1842 and in the 'Anecdotes of the Life of Sir James Steuart, Baronet', appended to Steuart's Works (1805). See also Paul Chamley $(1963,1965)$ and Skinner (1966, 1998), together with the entry in the new Dictionary of National Biography by the same author.

3 Rebellions in 1715 and 1745 by the exiled Jacobite claimants to the British throne, supported initially primarily by Highland Scots, caused great turmoil, particularly within Scotland.

4 This translates as: 'The first thing will be to convince completely that the revolution happening before our eyes was necessary in a natural way of things.'

\section{References}

Akhtar, M. A. (1978) 'Sir James Steuart on Economic Growth', Scottish Journal of Political Economy 25: 57-74.

Aristotle (1932) The Politics, with an English translation by H. Rackham, London: Heinemann.

Black, R. D. C. (ed.) (1986) Ideas in Economics, London: Macmillan.

Blair, Hugh (1767) NLS ms 23153, no. 61, 4 June.

Chamley, P. (1963) Economie politique et philosophie chez Steuart et Hegel, Paris: Librairie Dalloz.

— (1965) Documents relatifs à Sir James Steuart, Paris: Librairie Dalloz.

Coltness Collections, The (1842) Edinburgh: Maitland Club.

Davie, G. E. (1967) 'Anglophobe and Anglophile', Scottish Journal of Political Economy 14: 291-304.

de Senovert, M. (1789) Recherche des Principes de L'Economie Politique, Paris.

Eagly, R. V. (1961) 'Sir James Steuart and the Aspiration Effect', Economica 28: 53-61.

Eltis, W. (1986) 'Sir James Steuart's Corporate State', in R. D. C. Black (1986).

_ (1987) 'Steuart, Sir James', in J. Eatwell, M. Milgate and P. Newman (eds), The New Palgrave Dictionary of Economics, London: Macmillan.

Grossman, H. (1943) 'The Evolutionist Revolt against Classical Political Economy', Journal of Political Economy 51: 381-96, 506-22.

Hasbach, W. (1891) Untersuchungen über Adam Smith, Leipzig.

Hirschman, A. O. (1977) The Passions and the Interests: Political Arguments for Capitalism before its Triumph, Princeton NJ: Princeton University Press.

Hont, I. (1983) 'The Rich Country-Poor Country Debate in Scottish Political Economy', in I. Hont and M. Ignatieff (eds), Wealth and Virtue: The Shaping of Political Economy in the Scottish Enlightenment, Cambridge: Cambridge University Press.

Hutchison, T. (1988) Before Adam Smith, Oxford: Basil Blackwell.

Johnson, E. A. G. ([1937] 1960) Predecessors of Adam Smith, New York: Kelley.

Jones, P. (ed.) (1988) Philosophy and Science in the Age of Enlightenment, Edinburgh: John Donald. 
Kames: Henry Home, Lord (1779) Principles of Morality and Natural Religion, 3rd edn, Edinburgh.

King, J. E. (1988) Economic Exiles, London: Macmillan.

Kobayashi, N. (1967) James Steuart, Adam Smith and Friedrich List, Tokyo: Science Council of Japan.

- (1992, 1998) 'The First System of Political Economy: An Essay on Political Oeconomy of Sir James Steuart', Keizai Ronshu, Daitobunka University.

Low, J. M. (1952) 'An Eighteenth Century Controversy in the Theory of Economic Progress', Manchester School of Economic and Social Studies, 20: 311-20.

MacLaurin, C. ([1748] 1775), An Account of Sir Isaac Newton's Philosophical Discoveries, 3rd edn, Edinburgh.

McNally, D. (1988) Political Economy and the rise of Capitalism: A Re-interpretation, London: Berkeley, CA: University of California Press.

Marshall, A. N. ([1890] 1961) Principles of Economics, London: Macmillan.

Meek, R. L. (1967) 'The Rehabilitation of Sir James Steuart', in Economics and Ideology and Other Essays: Studies in the Development of Economic Thought, London: Chapman \& Hall.

Mirabeau, V. R. (1756) Friend of Man, Avignon.

Perelman, M. (1983) 'Classical Political Economy and Primitive Accumulation', History of Political Economy 15: 451-94.

Raynor, D. and Skinner, A. S. (1994) 'Sir James Steuart: Nine Letters on the American Conflict, 1775-1778', William and Mary Quarterly, third series, 51: 755-76.

Schumpeter, J. (1954) History of Economic Analysis, London: Allen \& Unwin.

Skinner, A. S. (1966) 'Introduction' to Steuart (1767).

— (1981) 'Sir James Steuart: Author of a System', Scottish Journal of Political Economy 28: 20-42.

— (1988) 'Sir James Steuart, Economic theory and Policy', in P. Jones (ed.), Philosophy and Science in the Scottish Enlightenment, Edinburgh: John Donald.

— (1996) A System of Social Science: Papers relating to Adam Smith, 2nd edn, Oxford: Clarendon Press.

— (1998) 'Introduction' to Sir James Steuart, 'An Inquiry into the Principles of Political Economy', edited by Andrew S. Skinner, London: Pickering \& Chatto.

— (2004) 'Steuart, Sir James, of Coltness and Westfield, third baronet (1713-1780)', Oxford Dictionary of National Biography, Oxford: Oxford University Press.

— (2005) 'David Hume and Sir James Steuart', in P. Jones (ed.), The Reception of David Hume in Europe, London: Thoemmes.

Smith, Adam ([1759] 1976) The Theory of Moral Sentiments, edited by A. L. Macfie and D. D. Raphael, Oxford: Clarendon Press.

- ([1776] 1976) An Inquiry into the Nature and Causes of the Wealth of Nations, edited by R. H. Campbell and A. S. Skinner, Oxford: Clarendon Press.

— (1987) Correspondence, Oxford: Clarendon Press.

Steuart, Sir James ([1767] 1966) Principles of Political Oeconomy: being an Essay on the Domestic Policy in Free Nations, edited in two volumes by A. S. Skinner. Edinburgh and Chicago: Oliver \& Boyd. All references are to this edition unless otherwise noted.

- (1805) The Works, Political, Metaphysical and Chronological, of the late Sir James Steuart of Coltness, Bart., in six volumes, London: Cadell and Davies.

Stewart, D. (1854-60) Works, edited by Sir William Hamilton, ten volumes, Edinburgh. 
Tortajada, R. (ed.) (1999) The Economics of James Steuart, London: Routledge.

Tribe, K. P. (1988) Governing Economy: The Reformation of German Economic Discourse, Cambridge: Cambridge University Press.

Vickers, D. (1970) 'Sir James Steuart', Journal of Economic Literature 8: 1190-5.

Viner, J. (1930) 'English Theories of Foreign Trade before Adam Smith', Journal of Political Economy 38: 249-310, 404-57.

Winch, D. (1983) 'Adam Smith's Enduring Particular Result', in Hont and Ignatieff (1983).

Yang, H.-S. (1994) The Political Economy of Trade and Growth: An Analytical Interpretation of Sir James Steuart's Inquiry, Cheltenham: Edward Elgar. 


\title{
6 Adam Smith \\ Real Newtonian
}

\author{
Leonidas Montes
}

Joseph Schumpeter was not an admirer of Adam Smith. But in his monumental History of Economic Analysis he praises 'the rudimentary equilibrium theory of chapter 7, by far the best piece of economic theory turned out by A. Smith' (1954: 189), simply because it was a theoretical predecessor of Walras. While Isnard, Smith, Say and Ricardo 'struggled or rather fumbled for it', for Schumpeter it was Walras who made the 'discovery' of economic equilibrium, 'the Magna Carta of economic theory' (ibid.: 242). Since then, it has been generally accepted that Smith was a forerunner, if not the founder, of general economic equilibrium theory. ${ }^{1}$ While some consider Walras's general economic equilibrium to be 'the peak of neoclassical economics' (Samuelson 1952: 61), nevertheless Adam Smith is widely seen as the 'father of our science'. Moreover, the most famous (and most elusive) metaphor in the history of economic thought, the invisible hand, has been interpreted as 'a poetic expression' that confirms Smith as 'a creator of general equilibrium theory' (Arrow and Hahn 1971: 2). One way or another, microeconomics textbooks too readily link Smith's invisible hand with some sort of equilibrium. ${ }^{2}$

Although the interpretation of Smith as the father of general equilibrium theory has already been challenged, this chapter contributes to this debate by interpreting Smith as a real Newtonian. Within this particular debate an intellectual appreciation of the eighteenth-century context, which was thoroughly pervaded by Newton's enormous influence, has led to an assessment of Newton's influence on Adam Smith. Mark Blaug has argued that the pivotal role of sympathy in TMS and that of self-interest in the $W N$ 'must be regarded as deliberate attempts by Smith to apply this Newtonian method first to ethics and then to economics' (1980: 52). Andrew Skinner also believes that Smith's economics 'was originally conceived in the image of Newtonian physics' (1969: 110). Indeed, Adam Smith was very much influenced by Newton.

The language of 'gravitation' and 'centre of repose' in chapter 7 of the first book of WN was thought a simple proof that Smith, by applying Newton's method to political economy, was led to general economic equilibrium theory. Smith's admiration for Newton, in addition to Newton's 
atomistic/mechanistic description of the celestial order, was taken as further evidence that he initiated the tradition of general economic equilibrium theory, relying upon the same ontological preconceptions (see Hetherington 1983). In this chapter I will challenge this view by arguing that emphasising Newton's influence on Smith is right, but for different reasons. Smith was a real Newtonian, but his methodology does not necessarily lead to a notion of equilibrium, nor to a theory of general economic equilibrium that requires an axiomatic-deductive methodology. The latter has generally been attributed to Newton, but Newtonianism was not conceived in that way by the Scottish Enlightenment. It was the French who adopted and adapted Newtonianism, fostering a methodology similar to that of Walras.

In the next section Newton's methodology will prove to be much more complex and subtle. Newton's method of analysis (method of resolution) and synthesis (method of composition) will be briefly analysed, and his conception of a potentially open-ended process of successive approximation will be discussed. The third section will start with a concise account of Smith's life, then analyse his methodology with special emphasis on chapter 7 of the first book of WN. In the last section it will be concluded, pace Blaug, who claims that Smith 'had a naïve view of what constituted Newton's method' (1980: 53), not only that Adam Smith was a careful interpreter of Newton, but that he actually mastered Newton's methodology in a very sophisticated manner. In this section special emphasis will be given to the context of the Scottish Enlightenment. It will be suggested that Smith's intentions in his History of Astronomy could be a consequence of a particular and distinctively Scottish reading of Newton. This chapter closes with some brief conclusions on the methodological approach followed in this chapter, and its import for our understanding of Smith's Newtonianism.

\section{A brief account of Newton's actual methodology}

In 1936 an auction at Sotheby's sold, rather cheap, 329 lots of Newton's manuscripts, nearly three million words. John Maynard Keynes managed to buy, and gradually reassemble, more than one-third of the collection (on all this, see Spargo 1992). Keynes, after reading the manuscripts, in his posthumous 'Newton, the Man' ${ }^{3}$ wrote: 'Newton was not the first of the age of reason. He was the last of the magicians, the last of the Babylonians and Sumerians' (Keynes 1972: 364). If Newton's reputation was built upon his scientific discoveries in mechanics, cosmology, optics and mathematics, the fact that he had spent much energy dealing with alchemy, theology, prophecies and ancient wisdom was simply ignored.

After Keynes's path-breaking essay, different biographies have offered a more detached and objective account of the real Newton, ${ }^{4}$ leading to a renewed interest in Newton's 'private science'. Newton was not only 
exceptionally well read in alchemical literature, but also had extensive practical experience. He was further a voracious reader of the Scriptures and theological treatises. Convinced that ancient sages knew the law of universal gravity, he spent much of his energies studying the prophecies in the Book of Daniel and the Book of Revelation. Many scholars would now agree that Newton's speculations about the nature of matter may have been influenced by his knowledge of alchemy, theology and ancient wisdom. As Patricia Fara nicely put it: 'for him gravity, alchemy, and God were intimately linked ... Newton's alchemical pursuits were not ancillary to his natural philosophy but rather formed an essential part of his religious endeavor to study God's activities from as many aspects as possible' (2003: 501). But what is the nature of Newtonianism? For answering this question, we must first uncover what Newton really said about his methodology.

Principia and Opticks are the best known and most important public sources for understanding Newton's method. Regarding Principia, ${ }^{5}$ its complete title Philosophiae Naturalis Principia Mathematica resembles, and explicitly pretends to supplant, Descartes's Principia Philosophiae (1644). One of the greatest achievements of Newton's 'experimental philosophy' resides in his method of resolution (analysis) and composition (synthesis). In his famous General Scholium, appended to the end of the second edition of Principia, Newton refers to the nature of his 'experimental philosophy' in which 'propositions are deduced from the phenomena and are made general by induction' (Newton 1687: 943). Then in the last query of his Opticks (numbered 31) ${ }^{6}$ he explicitly declares that 'analysis consists in making Experiments and Observations, and in drawing general Conclusions from them by Induction.... Synthesis consists in assuming the Causes discover'd, and establish'd as Principles, and by them explaining the Phaenomena proceeding from them' (Newton 1704: 404-5). In sum, the method of resolution allows us to infer causes from phenomena, and the method of composition allows us to infer a (or some) principle(s) from which we can explain other phenomena. ${ }^{7}$ Newton's understanding of scientific progress through his analytic-synthetic method clearly differs from the axiomatic-deductive approach that underpins general economic equilibrium theory.

At the end of the first paragraph of Principia's preface, aware of, and concerned about, the unknown nature of the force of gravity, Newton concludes: 'But I hope that the principles set down here will shed some light on either this mode of philosophizing or some truer one' (Newton 1687: 383, emphasis added). Newton was attacked for appealing to occult qualities, as he would be following the discredited Aristotelian-scholastic tradition. His efforts to rebut this accusation, or to explain his system, uncover another very interesting facet of Newton's methodology: a desire to uncover the real nature of things that even allows the existence of another possibility (recall 'or some truer one'). The father of the universal 
law of gravitation, talking about attraction in the last query of his Opticks, was even open to the possibility 'that there may be more attractive Powers' (Newton 1704: 376). Moreover, the four 'rules for the study of natural philosophy' have become emblematic for understanding Newton's 'experimental philosophy'. In particular, controversial rule 4, which was added for the third edition of Principia, states:

In experimental philosophy, propositions gathered from phenomena by induction should be considered either exactly or very nearly true notwithstanding any contrary hypothesis, until yet other phenomena make such propositions either more exact or liable to exceptions.

(Newton 1687: 796)

This statement is very different from the commonly-received view of Newton's legacy. Instead of an emphasis on the apodictic character of a theory, or a concern with its permanent explanatory powers, Newton simply leaves theories open-ended. This is a serious argument corroborating that an axiomatic-deductive model of science alone is neither Newton's, nor Smith's, inheritance, as will be discussed in the next section. Schliesser (2005) has given additional evidence for interpreting Smith's Newtonian theory of science as a research tool for a potentially open-ended process of successive approximation. ${ }^{8}$ Newton accepts that the progress of natural philosophy is open-ended, arguing for partial truth until proven otherwise, and does not consider mathematical event regularities as the hallmark of scientific progress. Laws, for Newton, including the 'universal' law of gravity, can be open to refinement as part of this successive approximation process. Adam Smith, as will be seen, understood this very well. ${ }^{9}$

Newton feels more at ease in his Opticks writing the successive thirty-one queries. This work was first published in English, therefore his Opticks was more popular, and certainly more accessible to the general public. ${ }^{10}$ The corpuscular theory of light entailed difficult questions, especially about the inner nature of matter. But Newton did not hesitate to finish his work 'proposing only some queries, in order to a farther search to be made by others' (Newton 1704: 339). In his last query 31, Newton also states:

And if no Exception occur from Phenomena, the Conclusion may be pronounced generally. But if at any time afterwards any Exception shall occur from Experiments, it may then begin to be pronounced with such Exceptions as occur. By this way of Analysis we may proceed ... in general, from Effects to their Causes, and from particular Causes to more general ones, till the Argument end in the most general.

(Ibid.: 404) 
This passage is another reflection of Newton's method of approximation to reality. ${ }^{11}$ Not denying truth, he is confident that deviations from actual phenomena in fact bolster up the advancement of scientific knowledge. If there are no deviations, our conclusions will stand, but if disruptions from phenomena do appear, we should simply enhance the pursuit of scientific truth through reiterative analysis that will successively lead to a new synthesis. However, this kind of dialectical methodology acknowledges not only a process of successive approximation to reality, but also a prioritisation of the method of resolution (or analysis). Indeed, 'in Natural Philosophy, the Investigation of difficult Things by the Method of Analysis, ought ever precede the Method of Composition' (ibid.: 404). This is a crucial point that has been relatively ignored: analysis precedes, and moreover has pre-eminence over, synthesis. ${ }^{12}$

Newton's account of scientific progress evidences his realism: cautious as he is about truth, he never denies its existence. For example, in the General Scholium, added to the second edition of Principia as a reply to his Cartesian critics, Newton declares that what really matters is that gravity 'exists' (Newton 1687: 943). The analogy we find with the search for the cause of gravity is not only the best example to understand what Eric Schliesser has termed Newton's 'modest realism', but also it is most likely the source for Newton's late concern with methodology. ${ }^{13}$ Newton had the answer for how the world worked, but he didn't know why it worked that way. In other words, if he could describe gravity he could not explain its causal powers.

So far I have concentrated simply on Principia and Opticks, but it must be mentioned that Newton's unpublished papers do present further evidence for the interpretation I have been trying to develop. ${ }^{14}$ Just to give one example, in a fragment that was probably intended for the Opticks, Newton refers to the method of resolution and composition, adding that 'he that expects success must resolve before he compounds. For the explication of Phaenomena are Problems much harder than those in Mathematicks' (McGuire 1970: 185). Scientific progress is not simply a matter of achieving mathematical regularity, nor is the latter a precondition of Newton's method. If his discoveries created a mathematical system of nature, this does not necessarily imply that Newton's natural philosophy encouraged a particular mathematical-positivistic interpretation of his method. ${ }^{15}$

\section{A brief account of Smith's methodology, with biographical notes}

Just in the last paragraph of Opticks, in query 31, Newton declared, '[a]nd if natural Philosophy and all its Parts, by pursuing this Method, shall at length be perfected, the Bounds of Moral Philosophy will also be enlarged' (Newton 1704: 405). This sentence was taken seriously by the eighteenth-century savants. George Turnbull fully reproduced this quota- 
tion on the title page of the first edition of The Principles of Moral Philosophy (1740). Francis Hutcheson, founding father of the Scottish Enlightenment, attempted a mathematical approach to morals, probably inspired by Newton. David Hume wished to build his 'science of man' explicitly emulating Newton's experimental method. Certainly Smith was no exception in this setting, therefore it is not surprising that he refers to ' $\mathrm{t}$ ] he great work of Sir Isaac Newton' (TMS: III.2.20,124), nor that Smith may have echoed Newton's famous sentence in the following:

in the manner of Sir Isaac Newton we may lay down certain principles known or proved in the beginning, from whence we count for the severall Phenomena, connecting all together by the same Chain. - This latter which we may call the Newtonian method is undoubtedly the most Philosophical, and in every science whether of Moralls or Natural Philosophy etc., is vastly more ingenious and for that reason more engaging than the other [Aristotle's]. ${ }^{16}$

(LRBL: 145-6, emphasis added)

When Isaac Newton, the father of modern physics, was eighty-one years old, in 1723, Adam Smith, the father of economics, was born in a small town called Kirkcaldy. After studying in Glasgow University under the 'never to be forgotten' Francis Hutcheson (Corr.: 309), Smith moved to Oxford in 1740. He returned to Kirkcaldy, and two years later he was offered the opportunity to give some public lectures, mainly on rhetoric and belles lettres, at Edinburgh. Smith built his reputation, becoming Professor of Logic at the University of Glasgow, and soon after in 1752 he was appointed Hutcheson's successor at the prestigious Moral Philosophy Chair. His course was divided in four parts comprising natural theology, ethics, jurisprudence and political economy (or what was also called 'expediency'). Based on his ethics teachings, he published in 1759 The Theory of Moral Sentiments, which was well received, establishing Smith's intellectual prestige. Due to the latter, in 1764 Smith was invited to a grand tour as tutor of the Duke of Buccleuch. This was a great opportunity to meet Voltaire, Quesnay and many eminent members of the French Enlightenment. ${ }^{17}$

The death of the duke's brother forced a return to London after more than two years on the Continent. Smith came back to his birthplace, Kirkcaldy, supported by the duke's considerable pension for life, devoting the next ten years to work on his magnum opus. While Smith's ideas on political economy had germinated during his lecturing on moral philosophy at Glasgow, finally in 1776 An Inquiry into the Nature and the Causes of the Wealth of Nations was published. Smith's great friend, David Hume, died the same year.

In 1778 Smith was appointed Commissioner of Customs and settled in Edinburgh. As Newton took very seriously his job as Warden and Master of 
the Mint, Smith was also a very responsible commissioner. This is a remarkable similarity of character, as both could have taken their positions as a simple sinecure.

Although Smith maintained his promise to write a 'theory of jurisprudence' (see TMS Adv. and TMS: VII.iv.37, 342), he ordered the burning of some folios that might have contained notes on that subject just before his death in 1790. His intention was to build a social science, and his project was underpinned by a particular methodology which was pervaded by Newton's influence. Fortunately Smith decided to preserve some essays (published as Essays on Philosophical Subjects), among which is his most methodological essay, History of Astronomy (EPS: 31-105), 'the pearl of the collection', according to Schumpeter (1954: 182).

Apparently Smith cared about this essay, as, while he was ill in 1773, he sent a letter to Hume, declaring:

As I have left care of all my literary papers to you, I must tell you that except those which I carry along with me there are none worth the publishing, but a fragment of a great work which contains a history of the Astronomical Systems that were successively in fashion down to the time of Des Cartes. Whether that might not be published as a fragment of an intended juvenile work, I leave entirely to your judgement; tho I begin to suspect myself that there is more refinement than solidity in some parts of it.

(Corr.: 168, emphasis added)

There is some debate regarding the quality of History of Astronomy (hereafter $H A$ ). As it was published certainly before 1758 (cf. EPS: 103), some scholars have simply considered it a 'juvenile work' that may even correspond to Smith's stay in Oxford. Nevertheless, the editors of the Glasgow Edition believe that $H A$ 'is one of the best examples of theoretical history' (EPS: 2), concluding that 'Smith's view of science appears more perceptive today than it will have done in the eighteenth century' (ibid.: 21). But Wightman, editor of EPS, considers that '[ $\mathrm{t}]$ o none of them [Smith's main essays] would a modern scholar turn for enlightenment on the history of the sciences' (EPS: 5). Specifically, HA, '[t] hough acceptable to a modern historian in its main lines, it contains so many errors of detail and not a few serious omissions as to be no longer more than a museum specimen of its kind' (EPS: 11). ${ }^{18}$ The actual nature of Newton's methodology suggested in $H A$ has been relatively neglected in comparison with the comments and research on the triad 'surprise, wonder and admiration', and it can be argued that it has even been underestimated. For example, Longuet-Higgins concludes that 'Smith's approach to the history of astronomy was that of a psychologist rather than a philosopher of science' (1992: 91). If Bernard Cohen suggested that 'Smith was well educated in Newtonian science' (1994: 66), Schliesser (2005 and forthcoming) and 
Montes (2003, 2006) have attempted a revival of the methodological import of Smith's $H A$, especially in some of its Newtonian aspects.

The subtitle of $H A$ reads 'The Principles which Lead and Direct Philosophical Enquiries; Illustrated by the History of Astronomy', immediately calling our attention to its methodological import. It begins with a psychological account of scientific progress: surprise, wonder and admiration are successive steps towards scientific progress. These psychological stages from 'what is unexpected', through 'what is new and singular', finishing up in 'what is great and beautiful' (EPS: 33), respectively, constitute the grounds for understanding the nature of scientific progress. Smith defines the role of philosophy as the study 'of the connecting principles of nature' (EPS: 45), stating:

Let us endeavour to trace it, from its first origin, up to that summit of perfection to which it is at present supposed to have arrived, and to which, indeed, it has equally been supposed to have arrived in almost all former times.... Let us examine, therefore, all the different systems of nature ... [that] have successively been adopted by the learned and ingenious.

(EPS: 46)

The conditional nature of scientific progress implicit in this passage is an aspect of Smith's understanding of Newton that has been neglected. For Smith science is an open-ended process of successive approximations which resembles Newton's real methodological legacy. Newton discovered that:

he could join together the movements of the Planets by so familiar a principle of connection, which completely removed all the difficulties the imagination had hitherto felt in attending them.... Having thus shown, that gravity might be the connecting principle which joined together the movements of the Planets, he endeavoured next to prove that it really was so.

(EPS: 98, emphasis added)

Smith's use of 'might be' is relevant. Moreover, Smith finishes his account of Newton's discoveries with the following sentence: 'Such is the system of Sir Isaac Newton, a system whose parts are all more strictly connected together, than those of any other philosophical hypothesis' (EPS: 104, emphasis added). This also suggests how the recurrent idea of connections that exist in nature is, in Smith's account of Newton, subject to approximation. Then Smith asserts that we should take Newton's principles 'as if they were the real chains which Nature makes use of to bind together her several operations' (EPS: 105, emphasis added). Note again, the 'as if'. Indeed, these examples show that Smith fully understood the 
open-ended nature of scientific enquiry. This is distinctively Newtonian, as we have already argued.

Now let us turn our attention to chapter 7, 'Of the natural and market Price of Commodities', in the first book of $W N$, the supposed foundation of general equilibrium theory. The natural price differs from the market (or actual) price that is determined by effective demand. Smith underlines:

The natural price, therefore, is, as it were, the central price, to which the prices of all commodities are continually gravitating. Different accidents may sometimes keep them suspended a good deal above it, and sometimes force them down even somewhat below. But whatever may be the obstacles which hinder them from settling in this centre of repose and continuance, they are constantly tending towards it.

(WN: I.vii.15, 75, emphasis added)

The idea of all prices, the use of the word gravitating and the idea of a centre of repose appear as additional evidence of Newton's influence, but one has also to remember that '[i]n Smith's day invoking Newton's name and borrowing his terminology was a commonly used rhetorical device' (Redman 1993: 225). After a couple of pages discussing some facts about how price fluctuations affect rent, wages and profits, Smith continues:

But although the market price of every particular commodity is in this manner continually gravitating, if one may say so, towards the natural price, yet sometimes particular accidents, sometimes natural causes, and sometimes particular regulations of police, may, in many commodities, keep up the market price, for a long time together, a good deal above natural price.

(WN: I.vii.20, 77, emphasis added)

Note that Smith carefully adds 'if one may say so' after gravitating, perhaps underlining its metaphorical character, or maybe aware that gravitation actually implied a different phenomenon. Indeed, Smith's use of gravitation in terms of prices emulates Newton's third law of action and reaction: 'to every action there is always an opposite and equal reaction', but it differs in an important way. For Newton action and reaction are always equal, and bodies are not only gravitating towards some central body, but they are all also mutually gravitating toward one another. In other words, if Smith's depiction of the price mechanism were actually Newtonian, all prices should gravitate towards one another, implying that the natural price should also gravitate to the 'prices of all commodities'. The late Bernard Cohen has argued that, because of this difference, Smith's application of Newtonianism to the price mechanism 'was perfectly correct up to a point; it was merely incomplete' (Cohen 1994: 65, emphasis in the original). 
Another point of divergence is that general equilibrium theory, since Walras's early contributions, has become increasingly mathematical, basically emulating the results of what Cohen (1980) terms the Principia's 'Newtonian style'. But it must be remembered that Smith is very cautious, and rather sceptical about the use of mathematics in moral philosophy (which, of course, included political economy). In a letter regarding Webster's compilation of Scottish population figures for a pension scheme, Smith explicitly declares: 'You know that I have little faith in Political Arithmetic and this story does not contribute to mend my opinion of it' (Corr.: 288). Although William Petty's Political Arithmetick was very influential, Smith had his reservations regarding this empirical method. In $W N$ he also states: 'I have no great faith in political arithmetic' (WN: IV.v.b.30, 534). If there was a lot of guesswork in applying political arithmetic during the eighteenth century, at least it can be granted that Smith's method in economics (and a fortiori in ethics), with the exception of some simple arithmetical operations such as averages, is not mathematical.

Moreover, regarding Smith's teleological view of the market, he is considering a process, not a final state. Blaug has expressed this view bluntly:

The effort in modern textbooks to enlist Adam Smith in support of what is now known as the 'fundamental theorems of welfare economics' is a historical travesty of major proportions. For one thing, Smith's conception of competition was ... a process conception, not an end-state conception. ${ }^{19}$

(Blaug 1962: 60)

Smith did not share a mechanical reductionism that, applied to economics, would explain the harmony of market forces within an idealised general equilibrium model. This reductionism presupposes a closed system, an assumption that is at the core of neoclassical economics, especially in relation to general equilibrium theory. Smith's political economy is that of an open system, as has been recently fostered by critical realism (see especially Lawson 1997, 2003).

The conviction that social phenomena can be treated mechanically, and individuals atomistically, has been wrongly ascribed to something that might be called 'Smithian Newtonianism'. The latter is a spurious interpretation of both Newton and Smith that has pervaded neoclassical economics and underlies the development of modern economic general equilibrium theories. If economists have simply relegated Newtonianism to forces in equilibrium, neglecting the actual meaning Newton gave to his laws and his complex methodology, this mechanical order does not necessarily follow towards Smith's conception of the market mechanism. Smith's realistic account of economic phenomena did not pave the way for the ontologically atomistic-mechanistic pre-assumption of neoclassical economics that has been epitomised by general economic equilibrium. 


\section{Leonidas Montes}

Finally, unconditional faith in a rational order, characterised by harmony, stability, balance or equilibrium, was a particularly French phenomenon, pervasive in Lavoisier, Laplace, Condillac, Lagrange and Condorcet. This tradition might have led to Walras and general economic equilibrium theory. However, the thinkers of the Scottish Enlightenment, and Smith in particular, did not consider that social phenomena could be reduced simply to a kind of mechanical equilibrium. Indeed, Smith used the word equilibrium only once in the $W N$, when criticising the doctrine of the balance of trade (WN: IV.iii.c.2, 489). In this context, how Smith understood Newton might be directly related to how the Scots assimilated Newtonianism, as I will suggest in the next section. The role that the Scottish Enlightenment played in the dissemination of Newton's ideas is an important feature that illuminates further the context of Smith's approach to Newton's methodology.

\section{Why did Smith understand Newton so well?}

The Scottish Enlightenment played a crucial role in spreading Newtonianism, and in my view this context might explain why Smith understood Newton so well. It is very difficult and highly nuanced to define what Newtonianism is all about. Indeed, Paul Wood has argued that 'his writings [Newton's] were read in such radically different ways that it is difficult to identify a unified Newtonian tradition in the moral sciences' (Wood 2003: 802). Eighteenth-century philosophes carefully adopted Newton's successful discoveries as a paradigm, but many of them adapted his methodology. I will suggest that the French interpreted Newton within a context in which their scientific institutions were still backing the Cartesian legacy. The Scots were not only determinant in disseminating Newton's legacy, but also had a different understanding of what Newtonianism really was. The latter shaped the British reception of Newton.

There is evidence that the Scottish universities were not only prominently Newtonian, but also determinant in establishing Newtonianism in Britain. From the 1690s onwards, they 'led the way in the institutionalization of the Newtonian system' (Wood 2003: 810). Christine Shepherd (1982) has done archival research on Newton's rapid acceptance at the Scottish universities from the 1660s up to early eighteenth century, concluding that Scotland witnessed 'a considerable degree of progress in natural philosophy at the end of the seventeenth century and during the early years of the eighteenth' (p. 83). ${ }^{20}$ This phenomenon was no doubt due to the enormous influence of the Gregories at St Andrews and Edinburgh, ${ }^{21}$ but was by no means exclusive to them. For example, John Keill (1671-1721), a Scotsman, began lecturing on Newton's natural philosophy in Oxford perhaps as early as 1699, becoming Savilian professor there in 1712, initiating an experimental course in Newtonian physics. ${ }^{22}$ 
In Britain perhaps the more influential and popular accounts of Newton's new system during the first half of the eighteenth century were Henry Pemberton's (1694-1771) A View of Sir Isaac Newton's Philosophy, published in 1728, a year after Newton's death, and Voltaire's (1694-1778) The Elements of Sir Isaac Newton's Philosophy (1738). But Colin MacLaurin's (1698-1746) notable An Account of Sir Isaac Newton's Philosophical Discoveries, which was published in 1748 , is perhaps the best account written in the first half of the eighteenth century. ${ }^{23}$

Colin MacLaurin was an exceptionally gifted Scottish mathematician who early in his life, when he was only fifteen, submitted a sophisticated thesis in which he expounded Newton's law of gravity. He rapidly assimilated Newton's calculus, and 'was arguably the most capable and energetic exponent of Newtonianism working in Scotland, if not in Britain, during the first half of the eighteenth century. He helped not only to consolidate the Newtonian hold on Scottish academe, but also to create public science in the Scottish Enlightenment' (Wood 2003: 102). MacLaurin grasped Newton's legacy, and his influence through his An Account of Sir Isaac Newton's Philosophical Discoveries was considerable in Scotland and in England. Perhaps Adam Smith was just another savant who benefited from MacLaurin's sophisticated interpretation of Newton. ${ }^{24}$

The French reception of Newton, and its context, were different. Initially it was through Newton's optical work and his reflecting telescope that he first became famous in French scientific circles. Newton's Principia was not ignored in France, simply rebutted. Huygens and Leibniz were competent critics of Newton's law of gravity, and, as inheritors of mechanical philosophy, they did their best to explain matter and its interaction as a cause for attraction. If in France it was difficult to accept the notion of a void, the idea of bodies attracting one another without any material cause was generally deemed preposterous. Indeed, the most entrenched notion in France was the insistence on mechanisms and contact between bodies. The latter clashed with Newton's existence of universal gravitation as a force operating universally and independently of any direct mechanical contact. Descartes had defined matter as an infinitely extended plenum, but Newton formulated his concept of universal gravitation operating in bodies in vacuo.

Voltaire's celebrated Letters Concerning the English Nation (1733) ${ }^{25}$ not only popularised Newton, but also evinces the context of a great divide between French Cartesianism and Britain's Newtonianism. The new system of natural philosophy had to break through the well established Cartesian regime that was deeply institutionalised in the French scientific community. ${ }^{26}$ Just to give one example, even if in Scotland Glasgow University took longer initially to accept Newtonianism, as early as 1711 Glasgow became part of the Newtonian network with the election of Robert Simson (1687-1768) to a Chair in mathematics (Wood 2003: 100). In the University of Paris the first Newtonian lectures were not given until 


\section{Leonidas Montes}

the 1740 s, as it had remained under the reign of Cartesianism (see Jacob 1988: 201). In fact:

[g]iven the tenacity with which members of the French Académie des Sciences in the first three decades of the eighteenth century attempted to find a mathematical defense of Cartesian vortex ... it is unsurprising that Newton's phenomenological physics was slow to take root in the Continent's colleges and universities.

(Brockliss 2003: 61, see also p. 85)

But France gave students an impressive education in pure mathematics. ${ }^{27}$ Britain, relying on a tradition initiated by Francis Bacon, gave more emphasis to Newton's 'experimental philosophy'. This created two rival traditions of physics: 'one mathematical and one experimental, which have affected the two countries' approaches to natural science ever since' (ibid.: 86). It was only at the end of the eighteenth century that Laplace, who dubbed himself 'the French Newton', could finally impose his own 'Newtonian agenda on the French scientific community' (ibid.: 85).

On the role of mathematics, the Scottish tradition interpreted Newton's underlying idea that mathematics is an instrument to describe nature, not a model of reality. ${ }^{28}$ Additionally, they generally conceived mathematics, and especially differential calculus, in the geometrical tradition unintentionally initiated by Newton. The superiority of analytical mathematics and abstract thinking was more pervasive and generally accepted by the French Enlightenment. The Scottish mathematical mind was more phenomenological, deeply influenced by Colin Maclaurin and Robert Simson's geometrical approach (see Olson 1971).

The idea of a division between Descartes's mechanical philosophy and Newtonianism is not original, ${ }^{29}$ neither is it a clear-cut phenomenon. Disputable as it may be, in my personal view there are general grounds for assuming that Britain and France stood by the side of their intellectual heroes. In addition, not only was Scotland an early advocate of Newtonianism but more important, the Scottish Enlightenment provided a unique setting for rapidly assimilating and applying original approaches to Newton's ideas. Natural philosophy induced a debate about metaphysics in general (see Stein 2002), theology and moral philosophy. Disagreement over the nature of gravity and the nature of matter entailed different metaphysical and theological aspects. This discussion was especially fruitful in Scotland, and it was mainly through the Scots that Britain rapidly became Newtonian.

The methodological differences between the French and British traditions of thought are a consequence of Newton's legacy. Patriotism, personal rivalries, different scientific agendas, political and cultural idiosyncrasies, among other things, contributed to this divide. If France 
generally promoted an axiomatic-deductive method, and Britain an inductive methodology based on experiments and observation, Newton defended a process of continuous approximation to reality framed by an analytic-synthetic method. The latter confirms the thesis that Adam Smith was a sophisticated interpreter of Newton's methodology. However, the Scottish context may have been an important influence on Smith's understanding of Newton.

\section{Some brief methodological conclusions}

This chapter has attempted to underline the importance of context in the analysis of our ideas, a theme that motivated the genesis of this volume. Rational reconstructions may lead to disputable conclusions if there is no emphasis on historical context. The practice of relating Smith to general economic equilibrium theory is just another example. Reality is historically and philosophically much more complex.

In my opinion, careful reading of the legacy of an author should emphasise not only what the author said, but why and how he said it, i.e. text, context and language play a significant and interdependent role. The real meaning of ideas requires more than a simple textual analysis. I believe the success of intellectual history lies in the often elusive combination of each of these three components. Emphasising only the text would be to run the risk of reading an author as though the text were written by a contemporary (a common practice in reading Adam Smith as a modern economist). Focusing exclusively on the context may mean missing the real essence of what the text says and what the author's intentions were in using particular words. It is a stubborn truth that words, apparently simple, but at the same time deeply complex, do matter. However, overemphasis only on hermeneutic approaches would risk a process in which the author, and his or her context, might simply disappear.

What is said involves why and how it was said. The critical question for the nature of what is said implies an ontological approach to uncovering reality: asking for the real nature of things. But this attempt is inadequate without a serious understanding of the context, and the meaning of the text, as we have learned from Quentin Skinner's influential work. ${ }^{30}$ In attempting to answer the question of the nature of Smith's Newtonianism, how Smith wrote about Newton and prices, and why he wrote about them, this trilogy has represented a major concern in the development of this chapter.

Of course understanding Newton's influence on Smith is much more complex than has generally been granted. The generally accepted position taken in order to invest Adam Smith as the father of general economic equilibrium is methodologically disputable. This brief analysis also suggests that Smith's Newtonianism is pervaded by the unique and distinctive phenomenon of the Scottish Enlightenment (see Dow 1987). 
The realism and pragmatism that pervade Newton's account of scientific progress was paramount to Smith's political economy, his ethics and jurisprudence. It was also a landmark of the Scottish context.

\section{Notes}

In this chapter I shall refer to five of the six standard books of The Glasgow Edition of the Works and Correspondence of Adam Smith by their abbreviations for references and quotations: The Theory of Moral Sentiments (TMS), An Inquiry into the Nature and Causes of the Wealth of Nations (WN), Essays on Philosophical Subjects (EPS), Lectures on Rhetoric and Belles Lettres (LRBL), and Correspondence of Adam Smith (Corr.). I am indebted to Eric Schliesser and the editors for their very helpful comments.

1 For example, Lionel Robbins praises the achievement of $W N$, which is in harmony with the most refined apparatus of the modern School of Lausanne' (1932: 69). Samuel Hollander, applying our modern knowledge of general equilibrium to an understanding of Smith's price mechanism, refers to 'the remarkable chapter' (1973: 117). Later he argues that 'still a price-theoretic orientation to the Wealth of Nations' has not been contradicted (Hollander 1987: 61), concluding that chapter 7 'contains an embryonic account of general equilibrium theory' (ibid: 65 ).

2 Mas-Collel et al.'s popular text among economics postgraduates, Microeconomic Theory, reads: 'The first fundamental theorem of welfare economies states conditions under which any price equilibrium with transfers, and in particular any Walrasian equilibrium, is a Pareto optimum. For competitive market economics, it provides a formal and very general confirmation of Adam Smith's asserted "invisible hand" property of the market' (Mas-Collel et al. 1995: 549; see also 327 and 524).

3 As far as I know this essay was read posthumously by Sir Geoffrey Keynes (John Maynard Keynes's brother) in July 1946, as part of Newton's tercentenary celebrations at Trinity College. Gleick (2003: 188) seems to believe that John Maynard Keynes had read the essay.

4 The classic accounts of Newton's life are by Bernard le Bovier de Fontenelle, who published in 1728 The Elogium of Sir Isaac Newton; William Stukeley, Newton's friend and follower, who wrote in 1752 Memoirs of Sir Isaac Newton's Life, and Sir David Brewster's one-volume The Life of Sir Isaac Newton (1831) and then his two-volume Memoirs of the Life, Writings, and Discoveries of Sir Isaac Newton (1855). The latter remained the classical biography of Newton as the father of the 'Age of Reason'. Although many biographies of Newton have been written since Keynes's essay, in my view Richard Samuel Westfall's Never at Rest: A Biography of Isaac Newton (1980), remains the best account of Newton's life and his intellectual context. (A condensed version entitled The Life of Isaac Newton was published in 1993.) Manuel's Portrait of Isaac Newton (1968) gives a provocative and rather Freudian reading of Newton, Hall's Isaac Newton: Adventurer of Thought (1992) is also an excellent biography, and recently White's Isaac Newton: The Last Sorcerer (1998) and Gleick's Isaac Newton (2003) have provided good accounts of Newton's life.

5 The first edition was published in 1687, thanks to Edmond Halley, by the Royal Society. The second, edited by Roger Cotes, in 1713, and the third, edited by Henry Pemberton, was published in 1726. The first English translation of Newton's Principia was made by Andrew Motte, and published posthumously in 1729. A revised version by Florian Cajori was published in 1934, and in 1999 Bernard Cohen and Anne Whitman published the new and long awaited com- 
plete translation of Principia, preceded by Cohen's excellent A Guide to Newton's Principia.

6 The first edition of Newton's Opticks was published in English in 1704, thirty years after it had been written, soon after the death of his lifelong rival Hooke (Newton had promised not to publish it while he was alive). In the 'Advertisement' to the first edition, Newton explained that he had withheld this work from publication since 1675 in order to 'avoid being engaged in Disputes'. The last query, numbered 31, was added for its first Latin edition, Optice, published in 1706. The latter was translated and prefaced by Newton's friend and staunch advocate Samuel Clarke. The Latin edition added seven new queries (numbered 25-31), and the second English edition, published in 1717, added eight more queries (numbered 17-24).

7 On this issue and its relation to Smith see different positions in Hetherington (1983) and Montes (2003).

8 In fact, Bernard Cohen, George Smith and Howard Stein are the leading Newtonian scholars who have investigated Newton's commitment to an open-ended process of successive approximation. For example, G. E. Smith (2002: 159) refers to rule 4, arguing that 'quam proxime amounts to an evidential strategy for purposes of ongoing research' and then brilliantly underlines that 'the process of successive approximations issuing from Newton's Principia in these fields has yielded evidence of a quality beyond anything his predecessors ever dreamed of' (ibid.: 162).

9 Andrew Skinner (1979, 2001) already had underlined connections between Smith, Kuhn and Shackle in terms of his philosophy of science, but Schliesser (forthcoming) is more precise in his treatment of 'Smith as a realist about Newton's theory'.

10 This simple difference between both oeuvres also entails two 'rather different traditions of doing science' (Cohen and Smith 2002: 31), though I should add that methodologically, as it will implicitly be suggested here, there is methodological evolution, more than simple differences between early and late editions of Newton's works.

11 In Montes (2003: 741-3), I pointed out some similarities between Newton's actual method and critical realism. A year after that piece was submitted The Cambridge Companion to Newton was published. In it the editor, George E. Smith, in his essay 'The Methodology of Principia', analyses Newton's four rules and refers to his second rule, writing that 'same effect, same cause - authorizes inferences that Charles Saunders Peirce would have labeled abductive in contrast to inductive' (Smith 2002: 160-1, emphasis in original). Considering that critical realism has defended a retroductive model of inference that very much resembles Peirce's abductive inference (see Lawson 1997: 294, n. 14), it is encouraging to read an eminent scholar like George E. Smith making the same link.

12 The editors of the Glasgow Edition rightly point out in their introduction to EPS that 'Smith's methodology would seem to conform to the requirements of the Newtonian method properly so called in that he used the techniques of analysis and synthesis in the appropriate order' (EPS: 12).

13 In a very suggestive essay, Strong (1952) argued for a sort of 'Newton Problem' (à la Smith), as his Principia and Opticks were originally delivered without reference to God (the General Scholium was added twenty-six years after the first edition of Principia in 1687, and the queries mentioning God first appeared in the Latin edition Optice in 1706 and especially for the second English edition of 1718). Certainly Newton's need to somehow explain the cause of gravity, the main attack from the Cartesians, may have influenced his reliance on a theological argument. But in my view Strong's argument can be extended to Newton's concern with his methodology as an open-ended process of 


\section{Leonidas Montes}

successive approximation. It is undeniable that Newton was well aware of his own experimental philosophy, but he became more methodologically explicit as he grew older.

14 For example, Kuhn's research on Newton underlines that although he 'has seemed to support the further assertion that scientific research can and should be confined to the experimental pursuit of mathematical regularity ... [c]areful examination of Newton's less systematic published writings provides no evidence that Newton imposed upon himself so drastic a restriction upon scientific imagination' (1958: 45).

15 Expanding on this view, see Montes (2003: 725-32). Strong (1951) investigates Newton's 'mathematical way', noting not only that his Method of Fluxions is first and foremost geometric, but also arguing for a 'mathematical experimentalism in which measurements and rules of measure prepare the mechanical principles' (p. 107). Mathematics, for Newton, 'is a tool devised to assist in the solution of physical problems' (ibid.). Elsewhere he defends the thesis of a Newtonian 'mathematical conceptualism' followed by MacLaurin, Pemberton and 'sGravesande, which contrasts with Keill's 'mathematical realism' (Strong 1957). Moreover, Newton's views on mathematics give pre-eminence to geometry.

16 As a caveat, this passage appears while Smith was lecturing on methods of presentation. There is another incidental reference to Newton in (LRBL: 204) and (LJ: 399), also a reference in a footnote to Isaac Newton's Representation to the Lords of the Treasury (WN: I.xi.h, 229). The reference to Newtonian philosophy in Smith's letter to the authors of the Edinburgh Review (EPS: 244) is also important.

17 In 1895 John Rae published his classic Life of Adam Smith. Since then nearly half a dozen biographies have been written, but Ian Simpson Ross's The Life of Adam Smith, published in 1995, remains the most authoritative.

18 Also Cleaver (1989), by contrasting theoretical and scientific discourse, resorts to $H A$ identifying three principles on the basic pre-assumption that there is a sort of equilibrium or uniformity that prompts Smith into an epistemology that lacks environmental/cultural setting.

19 Winch also convincingly argues against those who still want to view Smith as a precursor of general equilibrium theory, but he too readily suggests that "[w] hat Smith praised as "Newtonian method" fits his own work as well as that of general equilibrium theorists' (1997: 399).

20 L. Brockliss (2003) states that '[b]y the 1690s his [Newton's] theory of universal gravitation, as well as his work on light and colour, was being discussed by professors of philosophy in the Scottish universities' (p. 47).

21 James Gregory (1638-75) invented the reflecting telescope, was a fellow of the Royal Society, corresponded with Newton, became professor of mathematics in St Andrews in 1668, and then professor in the new mathematics Chair at the University of Edinburgh in 1674. David Gregory (1659-1708) succeeded his uncle James Gregory as professor of mathematics at the University of Edinburgh in 1683. In 1692 he was admitted to Balliol College, Oxford. Then, supported by Newton, David Gregory was appointed Savilian Chair of Astronomy at Oxford. He was an important disciple of Newton and a member of his intimate circle.

22 John Keill, according to his successor Desaguliers, was the first to teach Newtonian physics 'by experiments in a mathematical manner' (quoted in Guerlac 1981: 118)

23 Initially MacLaurin's contribution was conceived as a companion to a biography of Newton projected by Conduitt, who was married to Newton's niece, Catherine Burton. When John Conduitt died (1737) Colin MacLaurin con- 
tinued to work on his project, which was finally published two years after his death (see Strong 1957: 54). Other very popular and influential works were Francesco Algarotti's (1712-64) Sir Isaac Newton's Philosophy explain'd for the Use of the Ladies (1737), and Bernard de Fontenelle's (1657-1757) popular The Elogium of Sir Isaac Newton (1728). Notable is The Newtonian System of Philosophy, adapted to the Capacities of young Gentlemen and Ladies (1761) which contains the teachings of Tom Telescope (see Secord 1985).

24 Although MacLaurin's famous An Account of Sir Isaac Newton's Discoveries was not in Smith's library (it only contains MacLaurin's A Treatise of Fluxions, see Bonar 1966: 107), there is good reason to believe that Smith was familiar with this widely read book. For example, when Smith talks about Cassini's observations he mentions MacLaurin, 'who was more capable of judging' (EPS: 90)

25 Especially letter XIV 'On Des Cartes and Sir Isaac Newton', and to a lesser extent letter XV 'On Attraction' and letter XVI 'On Sir Issac Newton's Opticks'.

26 As Guerlac (1981) has argued, it was Malebranche and his followers, especially Maupertius and Clairaut, who disseminated Newton's legacy in France, though it has also been argued that they basically attempted to reconcile Newton with Descartes (see Gascoigne 2003: 299).

27 A representative feature of the British-French divide is that Leibniz's notation for calculus was adopted in France (and the Continent), while in Britain, Newton's notation prevailed during the eighteenth century. This is the famous 'the dot against d's'.

28 See Olson (1971). Also Guicciardini (1989) presents an analysis of British mathematics during the eighteenth century.

29 On Newton's reception in France, Pierre Brunet's L'Introduction des théories de Newton en France au XIII siècle I, Avant 1738 (the second volume never appeared) states that Cartesians opposed Newtonianism in France, but Guerlac (1981) argues that there was no such academic division. See also Hall (1975). Certainly Newton's Opticks was more popular, especially through Malebranche and his followers and de Fontenelle's popular Eloge, first read to the Royal Academy of Sciences in Paris in 1727.

30 Quentin Skinner's influential 'Meaning and Understanding in the History of Ideas' was originally published in 1969. For an interesting debate on his methodological position see Tully (1988). An extensively revised version of this influential essay, plus other of his important contributions on methodological issues, can be found in the first volume of the collection of his works (Visions of Politics: Regarding Method, 2002).

\section{References}

Algarotti, F. (1737) Sir Isaac Newton's Philosophy Explain'd for the Use of the Ladies, Naples.

Arrow, K. J. and Hahn, F. (1971) General Competitive Analysis, San Francisco: Holden-Day.

Blaug, M. ([1962] 1997) Economic Theory in Retrospect, Cambridge: Cambridge University Press.

([1980] 1992) The Methodology of Economics or How Economists Explain, Cambridge: Cambridge University Press.

Bonar, J. (1966) A Catalogue of the Library of Adam Smith, New York: Kelley.

Brewster, D. (1831) The Life of Sir Isaac Newton, London: John Murray.

- (1855) Memoirs of the Life, Writings, and Discoveries of Sir Isaac Newton, Edinburgh: Constable. 
Brockliss, L. (2003) 'Science, the Universities, and Other Public Spaces: Teaching Science in Europe and the Americas', in R. Porter (ed.), The Cambridge History of Science IV, Eighteenth Century Science, pp. 44-86, Cambridge: Cambridge University Press.

Brunet, P. (1931) L'Introduction des théories de Newton en France au XIII siècle I, Avant 1738, Paris: Libraire Scientifique Albert Blanchard.

Cleaver, K. C. (1989) 'Adam Smith on Astronomy', History of Science 27, 76: 211-18.

Cohen, I. B. (1980) The Newtonian Revolution: with Illustrations of the Transformation of Scientific Ideas, Cambridge: Cambridge University Press.

— (1994) 'Newton and the Social Sciences, with Special Reference to Economics, or, The Case of the Missing Paradigm', in P. Mirowski (ed.), Natural Images in Economic Thought: "Markets Read in Tooth and Claw", Cambridge: Cambridge University Press.

— and Smith, G. E. (2002) The Cambridge Companion to Newton, Cambridge: Cambridge University Press.

de Fontenelle, B. le B. (1728) The Elogium of Sir Isaac Newton, Paris.

Descartes, R (1644) Principia Philosophiae, Amsterdam.

Dow, S. C. (1987) 'The Scottish Political Economy Tradition', Scottish Journal of Political Economy 34, 4: 335-48.

Fara, P. (2003) 'Marginalized Practices', in R. Porter (ed.), The Cambridge History of Science IV, Eighteenth Century Science, pp. 485-507, Cambridge: Cambridge University Press.

Gascoigne, J. (2003) 'Ideas of Nature: Natural Philosophy', in R. Porter (ed.), The Cambridge History of Science IV, Eighteenth Century Science, pp. 285-304, Cambridge: Cambridge University Press.

Gleick, J. (2003) Isaac Newton, New York: Pantheon Books.

Guerlac, H. (1981) Newton on the Continent, Ithaca NY: Cornell University Press.

Guicciardini, N. (1989) The Development of Newtonian Calculus in Britain, 1700-1800, Cambridge: Cambridge University Press.

Hall, A. R. (1975) 'Newton in France: a New View', History of Science 13: 233-56.

— (1992) Isaac Newton: Adventurer in Thought, Cambridge: Cambridge University Press.

Hetherington, N. S. (1983) 'Isaac Newton's Influence on Adam Smith's Natural Laws in Economics', Journal of the History of Ideas 44, 3: 497-505.

Hollander, S. (1973) The Economics of Adam Smith, London: Heinemann.

- (1987) Classical Economies, Oxford: Basil Blackwell.

Jacob, M. C. (1988) The Cultural Meaning of the Scientific Revolution, New York: Knopf.

Keynes, J. M. (1972) 'Newton, the Man', in The Collected Writings of John Maynard Keynes X, Essays in Biography, pp. 363-81, London: Macmillan for the Royal Economic Society.

Kuhn, T. S. (1958) 'Newton's Optical Papers', in I. B. Cohen (ed.), Isaac Newton's Papers and Letters on Natural Philosophy, Cambridge: Cambridge University Press.

Lawson, T. (1997) Economics and Reality, London: Routledge. (2003) Reorienting Economics, London: Routledge.

Longuet-Higgins, H. C. (1992) “"The History of Astronomy”: a Twentieth-century View', in P. Jones and A. Skinner (eds), Adam Smith Reviewed, Edinburgh: Edinburgh University Press.

McGuire, J. E. (1970) 'Newton's "Principles of Philosophy": an Intended Preface 
for the 1704 Opticks and a Related Draft Fragment', British Journal for the History of Science 5: 178-86.

MacLaurin, C. (1748) An Account of Sir Isaac Newton's Philosophical Discoveries, London: Printed for A. Millar.

Manuel, F. E. (1968) Portrait of Isaac Newton, Cambridge MA: Belknap Press of Harvard University Press.

Mas-Collel, A., Whinston, M. D. and Gereen, J. R. (1995) Microeconomic Theory, Oxford: Oxford University Press.

Montes, L. (2003) 'Smith and Newton: some Methodological Issues concerning General Economic Equilibrium Theory', Cambridge Journal of Economics 27, 5: 723-47.

— (2006) 'On Adam Smith's Newtonianism and General Economic Equilibrium Theory', in L. Montes and E. Schliesser (eds), New Voices on Adam Smith, London: Routledge.

Newton, I. ([1687] 1999) Mathematical Principles of Natural Philosophy, edited by I. B. Cohen and A. Whitman, Berkeley, CA: University of California Press.

— ([1704] 1979) Opticks: or, a Treatise of the Reflections, Refractions, Inflections and Colours of Light, London: William Innys.

Newton-Smith, W. H. (1990) 'Realism', in R. C. Olby, G. N. Cantor, J. R. R. Christie and M. J. S. Hodge (eds), Companion to the History of Modern Science, pp. 181-95, London: Routledge.

Olson, R. (1971) 'Scottish Philosophy and Mathematics, 1750-1830', Journal of the History of Ideas 32, 1: 29-44.

Petty, W. ([1683] 1690) Political Arithmetick, London.

Rae, J. ([1895] 1965). Life of Adam Smith, New York: Kelley.

Redman, D. A. (1993) 'Adam Smith and Isaac Newton', Scottish Journal of Political Economy 40, 2: 210-30.

Robbins, L. ([1932] 1962) An Essay on the Nature and Significance of Economic Science, New York: Macmillan.

Ross, I. S. (1995) The Life of Adam Smith, Oxford: Clarendon Press.

Samuelson, P. (1952) 'Economic Theory and Mathematics: an Appraisal', American Economic Review 42, 2: 56-66.

Schliesser, E. (2005) 'Some Principles of Adam Smith's "Newtonian" Methods in the Wealth of Nations', Research in History of Economic Thought and Methodology 23A: 35-77.

_ (forthcoming) 'Realism in the Face of Scientific Revolutions: Adam Smith on Newton's "Proof" of Copernicanism', British Journal for the History of Philosophy.

Schumpeter, J. A. ([1954] 1994) History of Economic Analysis, Routledge: London.

Secord, J. A. (1985) 'Newton in the Nursery: Tom Telescope and the Philosophy of Tops and Balls, 1761-1838', History of Science 23, 60: 127-51.

Shepherd, C. M. (1982) 'Newtonianism in Scottish Universities in the Seventeenth Century', in R. H. Campbell and A. S. Skinner (eds), The Origins and Nature of the Scottish Enlightenment, Edinburgh: John Donald.

Skinner, A. S. (1979) 'Adam Smith: an Aspect of Modern Economics?' Scottish Journal of Political Economy 26, 2: 109-25.

- (2001) 'Adam Smith, the Philosopher and the Porter', in P. L. Porta, R. Scazzieri and A. Skinner (eds), Knowledge, Social Institutions and the Division of Labour, Cheltenham: Edward Elgar.

Skinner, Q. (1969) 'Meaning and Understanding in the History of Ideas', History and Theory 8: 3-53. 


\section{Leonidas Montes}

(2002) Visions of Politics: Regarding Method, Cambridge: Cambridge University Press.

Smith, A. ([1759] 1984) The Theory of Moral Sentiments, edited by D. D. Raphael and A. A. Macfie, Indianapolis IN: Liberty Fund.

- ([1776] 1981) An Inquiry into the Nature and Causes of the Wealth of Nations, edited by R. H. Campbell and A. S. Skinner, Indianapolis IN: Liberty Fund.

— (1982b) Essays on Philosophical Subjects, edited by W. P. D. Wightman and J. C. Bryce, Indianapolis IN: Liberty Fund.

- (1985) Lectures on Rethoric and Belles Lettres, edited by J. C. Bryce, Indianapolis IN: Liberty Fund.

(1987) Correspondence of Adam Smith, edited by E. C. Mossner and I. S. Ross, Indianapolis IN: Liberty Fund.

Smith, G. E. (2002) 'The Methodology of the Principia', in I. B. Cohen and G. E. Smith (eds), The Cambridge Companion to Newton, Cambridge: Cambridge University Press.

Spargo, P. E. (1992) 'Sotheby's, Keynes, and Yahuda: the 1936 Sale of Newton's Manuscripts', in M. Harman and A. E. Shapiro (eds), Investigations of Difficult Things: Essays on Newton and the History of the Exact Sciences in Honour of D. T. Whiteside, pp. 115-34, Cambridge: Cambridge University Press.

Stein, H. (2002) 'Newton's Metaphysics', in I. B. Cohen and G. E. Smith (eds), The Cambridge Companion to Newton, Cambridge: Cambridge University Press.

Strong, E. W. (1951) 'Newton's "Mathematical Way", Journal of the History of Ideas 12, 1: 90-110.

— ((1952) 'Newton and God', Journal of the History of Ideas 13, 2: 147-67.

- (1957) 'Newtonian Explanations of Natural Philosophy', Journal of the History of Ideas 18, 1: 49-83.

Stukeley, W. ([1752] 1936) Memoirs of Sir Isaac Newton's Life, London: Taylor \& Francis.

Tully, J. (1988) Meaning and Context: Quentin Skinner and his Critics, Princeton, NJ: Princeton University Press.

Turnbull, G. ([1740] 2005) The Principles of Moral Philosophy, edited by A. Broadie, Lancaster: Gazelle.

Voltaire ([1733] 1994) Letters Concerning the English Nation, Oxford: Oxford University Press.

— ([1738] 1992) The Elements of Sir Isaac Newton's Philosophy, edited by R. L. Walters and W. H. Barber, Oxford: Oxford University Press.

Westfall, R. S. (1980) Never at Rest: A Biography of Isaac Newton, Cambridge: Cambridge University Press.

- (1993) The Life of Isaac Newton, Cambridge: Cambridge University Press.

White, M. (1998) Isaac Newton: The Last Sorcerer, London: Fourth Estate.

Winch, D. (1997) 'Adam Smith's Problems and Ours', Scottish Journal of Political Economy 44, 4: 384-402.

Wood, P. (2003) 'Science, Philosophy, and the Mind', in R. Porter (ed.), The Cambridge History of Science IV, Eighteenth Century Science, pp. 800-824, Cambridge: Cambridge University Press. 


\title{
7 Adam Smith \\ Common sense and aesthetics in the Age of Experiments
}

\author{
Flavio Comim
}

Few notions have received as little attention in the historiography of economic thought as the notion of common sense. Yet, when one reads some of the classical texts in the history of economics, such as those of Adam Smith, Alfred Marshall or Maynard Keynes, one might notice references to expressions such as 'ordinary affairs of life', 'experience of everyday life' or 'conduct of practical life' in addition to direct references to 'common sense'. Often, the significance to these references is overlooked because due attention is not given to 'common sense' as a conceptual framework. The term 'common sense' is one of those ancient terms, ingrained in Western intellectual discourse, that has acquired many different connotations along the centuries. However, it was with the Scottish Enlightenment that common sense flourished and developed as a concept, a philosophical 'term of art', a merging of old notions of common sense (dating back to Aristotle and Avicenna) to address new philosophical problems.

Thomas Reid, the immediate successor of Adam Smith in the Chair of Moral Philosophy at Glasgow and also known as 'the father of common sense philosophy', argued for the existence of the notion of mind as an active power, and common sense as a set of innate principles of our constitution. With Reid, the notion of common sense acquired an ontological nature which, through James Beattie, influenced Immanuel Kant's distinction between 'common understanding' and 'reflective common sense'. During the Scottish Enlightenment other notions of common sense were developed, such as David Hume's psychological principle of practical action, in relation to his sceptical philosophy and empiricist epistemology. Common sense was also important to Adam Smith. A notion of common sense was behind Smith's view of science and provided an epistemological foundation for much of his work. For Smith, common sense may be seen as a way of emphasising the role of reason and judgement in the conceptualisation of phenomena with pragmatic and aesthetic content.

In order to understand the role of common sense in Smith's work we need to investigate the influence that the 'Age of Experiments' had on the Scottish Enlightenment. Experimentation became accepted as the 


\section{Flavio Comim}

distinctive method of modern science after the scientific revolution of the seventeenth century. Later, as is argued here, it provided the engine of the Scottish Enlightenment. Before that, the Aristotelian natural philosophy that prevailed in universities insisted on observation (a passive acceptance of knowledge nature has to offer) rather than on experimentation (an active and well defined interrogation of nature) as the principal method of science. Many early 'masters of experimentation', such as Bacon, Galileo, Boyle, Torricelli and Pascal, helped to establish the experimental method as the foundation of scientific procedures. However, no other method was so influential during the eighteenth century as Isaac Newton's experimental philosophy. In the hands of Scottish philosophers Newton's method became the methodological centre-piece of the Scottish Enlightenment.

The importance of Newton's experimental method for the establishment of 'systems of thought' was repeatedly acknowledged by Adam Smith. In his History of Astronomy (1795) he praised 'the superior genius and sagacity of Sir Isaac Newton' that made 'the greatest and most admirable improvement that was ever made in philosophy' (IV.67), leading to 'the most universal empire that was every established in philosophy' (IV.76). In his Theory of Moral Sentiments (1759), where he referred to 'the great work of Sir Isaac Newton' (III.2.20), Smith established the principle of Sympathy in the moral world along lines similar to those followed by Newton when he established the principle of Gravity in the natural world, giving rise to what became known as 'moral Newtonianism' (Ross 1995). In his Lectures on Rhetoric and Belles Lettres, Smith contrasted the Aristotelian method with the Newtonian as the two main alternatives for scientific enquiry, concluding that 'this latter... is undoubtedly the most Philosophical, and in every scien[c]e w[h]ether of Morals or Nat[ural] ph[ilosophy] etc., is vastly more ingenious and for that reason more engaging than the other' (Smith 1762-63: ii.133-4).

Yet, it is interesting to note that in Smith's accounts of science little emphasis is put prima facie on the experimental nature of Newton's method and that when the role of experience is mentioned by Smith it refers to 'the reality of which we have daily experience' or 'which is most familiar to us' (Smith 1795: IV.76). Moreover, he attributes importance to the Newtonian method in so far as it is able to connect, through the principle of gravity, diverse and irregular phenomena, therefore providing a 'beautiful machinery', a 'beauty of systematic arrangement of different observations connected by a few common principles' (Smith 1776: v.i.f.25), giving us 'a pleasure to see the phenomena which we reckoned the most unaccountable all deduced from some principle' (Smith 1762-63: ii.133-4). Thus, given the importance of Newton's experimental method to the scientific revolution of the seventeenth century and its relevance to the Scottish Enlightenment (including Smith's views on science and method), it is intriguing that Smith seems to have used the notion of 'experimental' in a different sense than Newton did. 
Based on an investigation of Adam Smith's works, this chapter argues that the notion of 'common sense' in the early history of economics cannot be properly examined unless related to the role of experiment and aesthetics in the conception of scientific 'systems of thought'. The influence of the role of common sense on the Scottish Enlightenment should not be ignored, in particular with its emphasis on broad actual facts, comparative historical-institutional excursions, non-individualistic representation of human nature and concern with practical issues based on the contingency of human nature (see Macfie 1955; Dow 1987; Dow et al. 1997).

The chapter is organised into three parts. The first part explores the main features of the Scottish common sense philosophy and its links with Newton's experimental method within the period of the 'Age of Experiments'. The second part investigates Adam Smith's notion of common sense and its significance to the Scottish Enlightenment. It examines David Hume's views on Newton's experimental philosophy and how, according to Raphael and Skinner (1978: 18), 'Smith thinks that philosophy or science is an enlargement of commonsense belief as represented by Hume'. Finally, the third part discusses the aesthetic view of experiment - according to which the importance of 'systems of thought' must be assessed in line with their aesthetic qualities of beauty and harmony - and Smith's advocacy of the Swiftian plain style of speech, expressing his belief that taste was exercised in creating systems of politics and economics. Smith's interpretation of the aesthetic qualities of Newton's experimental philosophy is also presented here.

The original contribution of the chapter consists in its attention to the Smithian notion of experiment and in its focus on common sense and aesthetics as important elements of the Scottish Enlightenment. It also argues that Newton's method remains essential for understanding the scientific foundations of the Scottish Enlightenment. Thus, the chapter aims to provide a more complex picture of the relation between experimental philosophy and the foundations of political economy.

\section{The Scottish common sense philosophy and the Age of Experiments}

During the Scottish Enlightenment, common sense developed into (1) a particular philosophical term achieving (2) more general uses in other areas, such as history and economics. From a philosophical perspective, common sense was explored mainly by Thomas Reid. From a general perspective, common sense was used by James Steuart, David Hume and Adam Smith, among others. Of course, such lines of demarcation among disciplines did not exist during the Scottish Enlightenment, but they are useful here to highlight the fact that many authors who did not delve into common sense as a philosophical term were, however, active in exploring 
its methodological and ontological uses. They were all part of what Davie (1976) called 'the central problem of Scottish Philosophy', namely the problem of reconciling the vulgar and the learned.

Thomas Reid was the first philosopher after Aristotle to extend the notion of common sense beyond ordinary conceptions (Somerville 1987: 418). His two main books, An Inquiry into the Human Mind on the Principles of Common Sense (1764) and Essays on the Intellectual Powers of Man (1785), constitute a good example of how the concept of common sense can be used in a variety of ways. In the Inquiry more emphasis was given to conceptions of common sense arising from original principles of mind. Reid believed that all human judgements must come from first principles, arguing that no one could reason unless some principles were taken for granted. Reid criticised David Hume's associationist epistemology and philosophical scepticism. He refuted Hume's theory of representation, claiming that impressions and ideas can be represented only if subject to a conceptualisation. He criticised the Humean argument that reason is the ultimate standard of judgement. Rather, he put forward the notion that the existence of the notion of mind as an active power (based on the working of common sense innate principles) was the ultimate standard of judgment: the foundations of our sense of reality. ${ }^{1}$ It is important to observe that despite Reid's criticisms of Hume's epistemology, he was aware that Hume (Reid 1764: 9) 'every now and then relapsed into the faith of the vulgar, and could hardly, for half a dozen pages [from Hume's Treatise of Human Nature], keep up the sceptical character'. This suggests that Hume and Reid, from the perspective of 'the central problem of the Scottish Philosophy' were not at opposite ends of the spectrum of the debate. While Hume believed that elaborate reasoning is important for all science and philosophy, he shared with Hutcheson and Reid the view that it must not have precedence over what is commonly done and believed in the common affairs of life (1739: 175). Therefore, it is not surprising that for Hume (p. 213) 'the philosophical system acquires all its influence on the imagination of the vulgar one' and that (p. 222-3) 'the true philosophy approaches nearer to the sentiments of the vulgar'. For Reid, the reconciliation between the vulgar and the learned was above all an epistemological issue. For Hume, such reconciliation was a practical issue.

While for Reid, common sense was an important epistemological principle which enabled him to emphasise the role of judgement in the conceptualisation of empirical phenomena, for Hume common sense was an important criterion needed to produce theory with pragmatic content. It is interesting to note, that despite these differences, both authors were heavily influenced by the development of what has been called the 'Age of Experiments', in the seventeenth century.

It was during this period that precision instruments, such as the telescope, microscope and pendulum clock, started being used in laboratory environments. More importantly perhaps, it was during this period that 
experimentation became a specific category of scientific activity (Morrison 1998) and that a new rhetorical form based on experimental activities was created (Cantor 1989). Although the seventeenth-century natural philosophers did not invent experimentation, they were the first to argue for a more systematic use of experiments. Among these, Francis Bacon was the first to criticise the Aristotelian distinction between theoretical and practical knowledge, advocating the pursuit of scientific theoretical knowledge through the use of practical experiments (Gower 1997: ch. 3). Bacon strongly criticised the arbitrary and haphazard manner in which experiments were pursued for entertainment. Also, by proposing a classification for various kinds of experiment, Bacon provided an elaborated account of the different ways through which evidence may be gathered from an empirical investigation. The most important of these categories refers to what he called prerogative instances, involving crucial experiments, that is, those experiments in which the information obtained provides decisive evidence about certain phenomena, allowing scientists to choose between different options.

Subsequently, Bacon's experimental methodology became institutionalised with the creation of the Royal Society in 1662, and Robert Boyle's and Robert Hooke's commitment to experimentation as the main engine of scientific enquiry. Yet this methodology was far from being free from criticism. There was a debate about scientific method in the seventeenth century concerning the role of mathematics and experiment as specific categories of scientific activities. On the one hand, Galileo, Hobbes and Descartes emphasised the significance of mathematics for the pursuit of scientific outcomes with a degree of certainty. On the other hand, Bacon, Boyle, Hooke, and other founders of the Royal Society, stressed the importance of experimentation as the basic engine of scientific enquiry. It is within this context - of an unsettled dispute between the role of mathematics and experiments in the pursuit of scientific activities - that Newton's contribution to the experimental method must be understood. Whereas most divergences in this dispute were merely a matter of emphasis, it seems that the prestige and recognition achieved by Descartes's doctrines (Russell 1961) led Newton and his supporters to emphasise the unique experimental nature of Newton's contribution.

Although Descartes, in his Discourse of Method (1637), allowed an important role for experiments in the verification of hypotheses, he built his philosophy on certain principles and axioms that had the status of innate ideas (such as cogito ergo sum) rather than of empirical observations. By starting from intuitively grasped principles held with certainty, Descartes could spread certainty to all derived knowledge through the use of systematic deduction and rigorous inferences. A common criticism of the Cartesian method is that it assumed a priori the existence of a philosophical system. Thus, it promoted a methodological order, named by d'Alembert the esprit de système (that is, the love of system for its own sake). 
It is here that Newton's experimental approach produces a shifting of emphasis towards a new methodological order called the esprit systématique (that is, the value of system is appreciated but not overemphasised).

Yet it must be noted that Newton, in his two major books, the Philosophiae Naturalis Principia Mathematica (1686), often referred to as the Principia, and Opticks (1704), emphasises different aspects of his experimental philosophy. In the Principia, where he discusses the phenomena of gravity, including the orbital motion of planets and comets, more attention is given to the mathematical properties that can reproduce the phenomena through the use of experiments. As argued by Cohen (1995: 132), 'it is precisely Newton's ability to separate problems into their mathematical and physical aspects that enabled Newton to achieve such spectacular results in the Principia'. In general terms, Newton's method of 'deduction from the phenomena' consisted of three stages. In the first, he transformed certain natural phenomena, the characteristics of which were grounded on the common sense of everyday life, into mathematical principles - elaborating a mathematical system similar to the natural system. In the second, he derived consequences from the application of mathematical techniques. Finally, he applied the results of the mathematical enquiry to the physical reality and contrasted them with the data from experiments. Therefore, in the context of the Principia, the language of mathematics appears to interact with the language of experimental practices (Redman 1997: 45).

Newton, in the Principia, also suggested a series of regulae philosophandi, or 'rules for natural philosophy', according to which the qualities of bodies can be known only by experiments and should not be inferred from hypotheses.

Thus, in the Principia, experiments were important means of:

1 Simplification and idealisation of empirical phenomena as inputs to Newton's mathematical systems.

2 Verification of theoretical results and explanation of a variety of natural phenomena based on a few common sense principles (e.g. gravity).

In his book Opticks Newton puts in evidence the essential features of the 'experimental philosophy' of the Opticks vis-à-vis the 'deduction from phenomena' method of the Principia. Although there is no incompatibility between the different discourses of these two books, it must be noted that Newton anchored his arguments on two distinct notions of experiment. As Gower (1997: 77-8) argues:

When, as in the Principia, the emphasis was upon the application of mathematical results to experimental or observational evidence, there was less of a problem, because the evidence was seen as an extension 
of common experience. But in the Opticks, phenomena were subjected to a Baconian style 'inquisition' intended to uncover 'secrets', with the accompanying danger that, unless suitable precautions are taken, what the phenomena reveal will be misleading.

Thus, it appears that what has been labelled 'Newtonian experimental philosophy' comprises two distinct notions of experiment. The first is a notion of experiment that confirms the previous notions individuals hold based on common sense. The second is a notion of experiment that 'discovers' or directly 'uncovers secrets of' phenomena. According to Newton, there is a proper moment in which each of these notions should be used. They are all part of what he called, in the Opticks, the methods of analysis and synthesis. By analysis he understood the compilation of particular causes towards a more general argument concerning the phenomena experienced by the scientist. Experimentation, observation and the principles of geometry and mechanics are essential parts of this method. Subsequently, he argued, the method of synthesis, should be used, based on general principles, in a contrary order than in the method of analysis (that is, from generalisations to phenomena), to explain all the phenomena and their consequences. It was important for Newton that this sequence was respected. It would lead initially to the elaboration of a system, which in turn would be used later to explain a wide diversity of phenomena based on a small web of principles.

Now, once we contemplate Newton's experimental philosophy as a whole, it seems that its most important aspect consists in the high degree of complementarity between its experimental and mathematical parts. On the one hand, if Newton's experiments could stand by themselves without the help of his subtle geometry, we would be back to the world of Bacon. On the other hand, if the systemic nature of his method was maintained, without his insistence on grounding its starting points on experience and experiment, we would be back to the world of Descartes. Therefore, the Newtonian system is neither an imagined construct nor a collection of haphazard empirical laws but something that transcends both. Experiments were important for Newton because they provided realisticness to his mathematical constructs and application for their results.

The reference that most people would have understood in Newton's day, and perhaps for a century or more afterwards, relates to his discovery of the principle of universal gravitation. It really impressed the minds of his time that he was able to elaborate a 'system of the world', explaining phenomena as diverse as the tides of the seas or planetary motion, using a single mathematical representation of a unique principle. Moreover, Newton's arguments were supported and promoted by many interpreters who deciphered the inaccessible mathematics of the Principia to the average well educated person. Among those, the most important constituted a group that Cohen (1972: v) called the 'triumvirate of great 
vulgarizers', namely Henry Pemberton, Colin MacLaurin and Voltaire. It is of significance that these interpreters, while engaged in the explanation of the substantive results contained in Newton's experimental philosophy, have also acknowledged that its relevance was based on its (1) conformity to individuals' daily experiences (common sense), and (2) aesthetic qualities.

The starting point for the analysis in the Principia is the notion of the power of gravity. Gravity is the foundational principle of Newton's system. It forms the basis from which other laws of motion are derived. Once it is formulated in a law, it provides grounds for explaining other phenomena. Gravity is not for Newton one of the Cartesian axioms nor a pure empirical/experimental principle. Gravity is, for him, and as far as it matters for his interpreters, a principle based on a tacit shared consensus among all individuals, that is, a common sense principle. MacLaurin (1748: 114) comments that 'Because the power of gravity is so well known to us, when we enquire into other powers, we endeavour to compare them with that of gravity, and to determine their proportion'. He also puts great emphasis on the argument that Newton's laws of motion are confirmed by 'experience' or 'constant experience' because they represent phenomena that are 'known to everybody'. The idea seems implicit in his reasoning, that the most simple phenomena consist in those experiences we are most acquainted with and, therefore, are most convinced of their reliability. As he observes (ibid.: 192), 'It is always from the most simple kind of phaenomena that we can trace with the greatest certainty the analysis of the laws of nature; from which we afterwards may proceed to such as are more complicated and abstruse'. Thus, as far as the power of gravity is a central notion to Newton's experimental philosophy, 'experimental' acquires the meaning of 'according to common sense experience' rather than of 'based on experiments'. This reading of Newton's philosophy seems to be confirmed by Pemberton's description of Newton's justification of his three laws of motion. There is a passage in Pemberton's book where he argues that:

Having in the preceding chapter deduced the three laws of motion, delivered by our great philosopher, from the most obvious observations that suggest them to us, I now intend to give more particular proofs of them, by recounting some of the discoveries which have been made in philosophy before Sir Isaac Newton. For as they were all collected by reasoning upon those laws, so the conformity of these discoveries to experience makes them so many proofs of the truth of the principles, from which they were derived.

(Pemberton 1728: 48, emphasis added)

Although Newton uses gravity, and the law of universal gravity, to elaborate his 'system of the world', he acknowledges that he is unable to explain 
the origin, or cause, of this power. He relies on the common sense perception that 'gravity really exists' in order to build a system which explains a wide range of diverse phenomena of heaven and earth. The realisticness of Newton's system was considered one of his most notable achievements by some of his contemporaries (see Voltaire 1738: Introduction).

However, the common sense element of Newton's experimental philosophy is not limited to the justification of the notion of gravity. It also appears at the very notion of experiment in Newton's works, which was related to the ordinary understanding of everyday experience. Cohen (1995: 126) argues that 'it seems to have been a tacit postulate that any reasonably skilled man or woman should be able to reproduce an experiment or observation, provided that the report of that experiment or observation was given honestly and in sufficient detail.' It is not being suggested here that the whole of Newton's philosophy was based on common sense. There are many postulates and conclusions of his theories that were certainly at odds with the understanding of the average citizen. However, what must be emphasised is that the overall reliability of Newton's procedures was based on principles appealing to the common sense of his time.

Another important element in Newton's experimental philosophy was its aesthetic qualities. To a certain extent, the principles of simplicity and unity of design - the foundations of his idea of beauty - were derived from his religious beliefs. Because God organised from a single perspective all variety and diversity of phenomena on earth, people would have to use reason to understand the beauty of unification of experience. ${ }^{2}$ This idea becomes clear in MacLaurin's argument that:

The admirable and beautiful structure of things for final causes, exalt our idea of the Contriver: the unity of design shews him to be One. The great motions in the system, performed with the same facility as the least, suggest his Almighty Power, which gave motion to the earth and the celestial bodies, with equal ease as to the minutest particles.... The simplicity of the laws that prevail in the world, the excellent disposition of things, in order to obtain the best ends, and the beauty which adorns the works of nature, far superior to any thing in art, suggest his consummate Wisdom.

(MacLaurin 1748: 400-1, fourth emphasis added)

In this context, experiments were valued as an element in the elaboration of a unified system. But not any system should be considered acceptable. Rather, only those systems displaying a simple and ordered structure should be accepted as compatible with God's unity of design. From this perspective, experiments, experience and observations alone could not provide the elements required for an aesthetic appreciation of reality, unless helped by those values of an esprit systématique. Experiments could not produce results by accident, nor as a consequence of random 


\section{Flavio Comim}

experimentation, but rather needed to belong to a systematic enquiry in order to achieve the aesthetic standards compatible with God's unity of design. Pemberton (1728: 3) points out that 'Perspicuous reasoning appears not only beautiful; but, when set forth in its full strength and dignity, it partakes of the sublime, and not only pleases, but warms and elevates the soul.' From this perspective, it might be said that in Newton's philosophy, the principle of gravity consists also in an aesthetic principle: not only is it a very familiar and simple principle but it also serves as an organising element within the esprit systématique, arranging a diversity of phenomena. As MacLaurin notes:

We have a remarkable instance of the beauty of truth when we observe what a variety of phaenomena arise from so few simple principles as the spherical figure of the earth, its diurnal motion, and the obliquity of its axis, as we take a survey of the earth from the torrid to the frigid zone, or from the equator to the poles, and attend to the phaenomena of heat and cold, as well as of those of day and night, and of the apparent motions of the stars. A diversity of phaenomena so very great, arising from two principles of so simple a nature, affords a curious speculation to the understanding, as well as a pleasing entertainment to the imagination, and serves to suggest the admirable fertility of which nature is capable in its productions.

(MacLaurin 1748: 250, emphasis added)

To conclude, there are two important claims made here concerning the Scottish common sense philosophy and the Age of Experiments: (1) that common sense was part of the Scottish Enlightenment, as perceived by distinguished philosophers, such as Reid and Hume and (2) that there were links between common sense and the experimental methodology developed by Newton (that its main principle, the power of gravity, derives its empirical appeal from being an element of common sense reality, and that its aesthetic qualities provide the background from which experiments and concepts should be assessed). In what follows, we analyse the influence of common sense and the experimental philosophy on the development of Adam Smith's views on science and method.

\section{Adam Smith's philosophy and method}

It is generally acknowledged by historians of economics that Adam Smith's moral philosophy was inspired by Newton's experimental method (Thomson 1965: 232, Skinner 1972: 308 and Campbell 1971: 21, among others). This also seems to have been the case of David Hume, one of the most influential minds of the Scottish Enlightenment, who was himself a close friend of Smith and an undisputed intellectual influence on him. Following Newton's view, expressed at the end of the Opticks (1979: querie 
3.i), that 'if natural philosophy in all its parts, by pursuing this method, shall at length be perfected, the Bounds of Moral Philosophy will also be enlarged', it might be argued that Hume's A Treatise of Human Nature: being an Attempt to introduce the Experimental Method of Reasoning into Moral Subjects (1739) consisted in an attempt to apply Newton's experimental method to the study of human nature. Many parallels can be traced between Hume's and Newton's experimental method, such as their distrust of Cartesian a priori principles, their appeal to experience as a way to avoid metaphysical speculations and their use of the methods of analysis and synthesis. Without delving into the controversial aspects of the relation between Newton's and Hume's philosophy (for that, see Redman 1997), it may be argued that Hume modified Newton's notion of experimental method $^{3}$ in at least two fundamental senses:

1 though accepting Newton's belief in the uniformity of nature, he removes it from its religious foundation. He proposes a purely psychological account of science and human nature (see Cassirer 1951: 62). In his psychological approach, Hume argues that (1739: 136) 'when we transfer the past to the future, the known to the unknown, every past experiment has the same weight'. The notion of experiment looses the epistemological priority Newton had granted it in the Opticks;

2 he puts emphasis on the experimental aspect of Newton's method concerning the role of common sense in the foundation of first principles. At his hands, 'experimental' becomes 'empirical', 'related to experience', rather than 'related to experiments'. This character of Hume's experimental method provided him with the general principles of resemblance, contiguity and causation which, according to him, explain the association of ideas. About the sciences and arts, cultivated either 'in the schools of the philosophers' or 'in the shops of the meanest artisans', he observes that:

None of them can go beyond experience, or establish any principles which are not founded on that authority. Moral philosophy has, indeed, this peculiar disadvantage, which is not found in natural [philosophy], that in collecting its experiments, it cannot make them purposely, with premeditation, and after such a manner as to satisfy itself concerning every particular difficulty which may arise. When I am at a loss to know the effects of one body upon another in any situation, I need only put them in that situation, and observe what results from it. But should I endeavour to clear up after the same manner any doubt in moral philosophy, by placing myself in the same case with that which I consider, 'tis evident this reflection and premeditation would so disturb the operation of my natural principles, as must render it impossible to 
form any just conclusion from the phaenomenon. We must therefore glean up our experiments in this science from a cautious observation of human life, and take them as they appear in the common course of the world, by men's behaviour in company, in affairs, and in their pleasures. Where experiments of this kind are judiciously collected and compared, we may hope to establish on them a science, which will not be inferior in certainty, and will be much superior in utility to any other of human comprehension.

(Hume 1739: xviii-xix, emphasis added)

Although there is no contradiction with Newton's experimental method - since he also uses experimental to refer to common sense experience, as in the case of the principle of gravity - there is an implicit criticism of the notion of experiment in social sciences as an 'active interrogation of nature'. In social sciences, human reflexivity prevents the realisation of successful experiments. Therefore, it seems difficult to imagine the use of crucial experiments as a way to settle disputes.

It might be argued that Adam Smith's method was heavily influenced by Hume's interpretation of Newtonian experimental science. There are many references in Smith's writings to 'experimental', meaning 'common sense experience'. Raphael and Skinner (1978) argue that Smith's notion of imagination draws on an application of Hume's view of common sense to the hypotheses of science and that 'Smith thinks that philosophy or science is an enlargement of commonsense belief as represented by Hume' (p. 18).

Smith, in his History of Astronomy (1795), establishes the foundations of scientific enquiry on psychological principles largely influenced by 'the ordinary train of things', 'the natural course of things', 'the things agreeable to experience' and 'the things [with which] we are most familiar'. According to his perspective, the object of science is to eliminate psychological discomfort or 'embarrassment' caused by unfamiliar phenomena which cannot be explained by the familiar harmonic principles of our imagination. Smith's argument that unfamiliar phenomena cause psychological discomfort is based on his view that the mind takes pleasure in observing resemblances between different objects (ibid.: II.i). When new and unexpected phenomena contradict the customary connections employed by the mind, individuals react with wonder and surprise. Smith's discussion of the things with which we are most familiar conveys a notion of common sense consisting of psychological principles shared by all mankind, and closely connected by 'the reality of which we have daily experience' (ibid.: IV.76). He claims that (ibid.: II.12) 'no system, how well soever in other respects supported, has ever been able to gain any general credit on the world, whose connecting principles were not such as were familiar to all mankind'.

In his Theory of Moral Sentiments (1759) Smith organises experience con- 
cerning moral phenomena through concepts (e.g. of 'sympathy' and an 'impartial spectator') based on principles familiar to all mankind. Sympathy, for Smith, meant the capacity for fellow feeling, the ability to put oneself in other people's shoes. As such, it is an essential element in the explanation of how moral judgements are formed, working as a principle and not as a determinant of moral discrimination (Macfie 1967: 91-2). Sympathy has the methodological status of a first principle, relevant for individuals' conceptualisation of their experiences. It has the same methodological role as of Newton's concept of gravity, that is, it is a familiar, simple and shared concept used to organise scientific thought. This way of organising scientific enquiry involves explaining a wide diversity of phenomena based on a small set of first principles. As far as Smith's ethics is concerned, as pointed out by Macfie (1967: 44), it is a question of working out 'a highly refined pattern of ethical theory through a rather simple web'.

It might then be suggested that Smith sided with Hume on the interpretation of the experimental aspects of Newton's philosophy. This argument is corroborated by Wightman's (1975) point that, although there are some parallelisms between the Wealth of Nations and the Principia (basically arising from the use of a Newtonian rhetoric in the explanation of economic laws), what might be called a Smithian 'first law of exchange'

necessarily differs, as does the whole of Smith's corpus, from the 'Newtonian' method sensu stricto in not being based on experiment. The practice of the mature Smith may be compared with that of the youthful Hume: the latter explicitly refers to the 'application of experimental philosophy to moral subjects' (Treatise, $\mathrm{xx}-\mathrm{xxiii}$ ); reveals an adequate insight into the 'method' of this philosophy even to a clear recognition of the 'peculiar disadvantage' in moral philosophy 'which is not found in natural'; proceeds with characteristic Humean doublethink to confound experiment and observation; and finally (332 f.) sets out as 'proofs' of his 'hypothesis' eight 'experiments' that are in fact mere exemplifications.

(Wightman 1975: 64, emphasis in original)

Thus, in the application of Newton's method to moral subjects, Hume and Smith rejected the notion of experiment of the Opticks, choosing instead to elaborate on the notion of the Principia: experimental referring to experience, to observation, to common sense knowledge and to widely shared principles. They retain the idea of system and the Newtonian advice that a principle is important for its capacity of theoretical arrangement, not for its certainty (as is a requirement of the Cartesian method). In Hume's hands, the new methodological model was transformed into history rather than mathematics (Cassirer 1951). Consequently, experiment becomes in the Humean and the Smithian moral philosophy a reference to a concrete illustration of the validity of the theoretical system behind it. 
According to Lindgren (1969: 902), certain theoretical arrangements were 'compared in terms of both the degree of coherence they introduce into appearances and the extent to which the patterns of association they employ are familiar to the better part of mankind'. Following this interpretation, history becomes important not for its factual accuracy but for its ability to convey a sense of realisticness to the theoretical system being proposed. Campbell and Skinner (1976: 43) have noted that:

Smith's friends did not always recognise that his 'proper attention to facts', even to Hume's 'curious facts', was to prove an immediate source of attraction. Having gained attention in this way, Smith then commanded respect because the practical conclusions which followed from the chief elements of his system were evidently related to the economic problems of the middle of the eighteenth century.

This may explain why there is a historical dimension in the Wealth of Nations which serves mainly 'as a fiction for analytical purposes' (for more, see Hollander 1979). This character of Smith's experimental method was also understood by Alfred Marshall, who argued that:

Adam Smith saw clearly that while economic science must be based on a study of facts, the facts are so complex, that they generally can teach nothing directly; they must be interpreted by careful reasoning and analysis. And as Hume said, the Wealth of Nations 'is so much illustrated with curious facts that it must take the public attention'. This is exactly what Adam Smith did: he did not very often prove a conclusion by detailed induction. The data of his proofs were chiefly facts that were within everyone's knowledge, facts physical, mental and moral. But he illustrated his proofs by curious and instructive facts; he thus gave them life and force, and made his readers feel that they were dealing with problems of the real world, and not with abstraction; and his book, though not well arranged, is a model of method.

(Marshall 1890: 759, n. 2, emphasis added)

To conclude, one characteristic of Adam Smith's method of political economy seems to be its appeal to common sense, to facts 'within everyone's knowledge' as a means of grounding his 'system of thought' to concrete aspects of reality. Following Newton, who grounded his experimental philosophy on the principle of gravity, Smith grounded his method on common sense principles, such as sympathy, self-interest or division of labour. In order to have a full grasp of Smith's method, we need to discuss the Newtonian aesthetic heritage and its links with common sense, to which we now turn. 


\section{The Enlightenment and the aesthetic view}

To the eyes of a twentieth-first-century scientist, the interest during the eighteenth century in aesthetics and science may seem unfamiliar, to say the least. Yet the Enlightenment fostered a belief in a unity of nature which was manifested in a conception of interdependence between aesthetics and experimental science. As Cassirer (1951: 277) argued, 'It is as if logic and aesthetics, as if pure knowledge and artistic intuition, had to be tested in terms of one another before either of them could find its own inner standard and understand itself in the light of its own relational complex.' According to him, Cartesian philosophy gave rise to an objective conception of aesthetics that emphasised the absolute unity of knowledge: the diversity of empirical heterogeneous forms (experiences) should be reduced to a single principle; truth and beauty were seen as different aspects of the same thing; the criterion 'unity in multiplicity' became the aesthetic standard of classical theory and the ideal of simplicity became a corollary of beauty and truth. Subsequently, the Newtonian and Humean philosophy stimulated a shift in the concept of science and aesthetics. The Cartesian emphasis on the 'nature of things' was ultimately replaced by the notion of 'the nature of man'. Aesthetic objectivism was now superseded by a psychological approach which portrayed aesthetics as a purely human phenomenon. As Kivy (1973: 10) observes, The question of the 'standard of taste' is the idée fixe of Enlightenment aesthetic theory. The growing appeal to subjective rather than objective criteria in aesthetic judgement naturally led to the fear that a notion of 'correct' and 'incorrect' judgement, of 'good' taste and 'bad', could not be philosophically sustained. For the Enlightenment, the answer to the question of a subjective standard of taste was abiding faith in an unchanging human nature. Summers (1987: 330) points out that Hume, in his essay On the Standard of Taste, argues that there is no universal standard of beauty but that 'general rules of art' can be founded 'on experience and on the common sentiments of human nature'. Two important characteristics of this psychological approach to science and aesthetics are the concept of 'taste': (1) is interpreted as a sort of common sense and (2) is based not on logic, but on experience. Indeed, aesthetic judgements receive a certain primacy over exclusively logical judgements. As argued by Cassirer (1951: 306-7):

This advantage does not consist in the fact that the aesthetic judgment achieves more than the logical, but that it demands less. For in resisting all false generalisations and in making assertions not about objects as such, but about our relations to them, the aesthetic judgment is enabled to achieve that conformity for which the sciences of the objective world strive in vain.

The experimental nature of Hume's method is also manifested in his notion of 'beauty'. His associationist epistemology suggests that experience 


\section{Flavio Comim}

is the source of aesthetic judgements. More specifically, the feeling of beauty results from those experiences which correspond to the general impression concerning the experience of the beautiful. A similar line of argument is held by Hutcheson, who in An Inquiry Concerning Beauty, Order, Harmony, Design (1725), relates beauty to the things that are 'agreeable to the sense of men'. For him, the idea of beauty was derived from a balance between uniformity among variety ${ }^{4}$. He believed that 'variety' increases the beauty in equal uniformity and that the greater uniformity increases the beauty among equal variety. For this reason he proposed that people must 'choose to operate by the simplest means, to invent general theorems, and to study regular objects' (p. 91), given that these are means of expressing a certain order and organisation that please the mind. On section III of his Inquiry, on 'the beauty of theorems', he argues:

That we may the better discern this agreement or unity of an infinity of objects, in the general theorem, to be the foundation of the beauty or pleasure attending their discovery, let us compare our satisfaction in such discoveries with the uneasy state of [mind] when we can only measure lines, or surfaces, by a scale, or are making experiments which we can reduce to no general canon, but [are] only heaping up a multitude of particular incoherent observations. Now each of these trials discovers a new truth, but with no pleasure or beauty, notwithstanding the variety, till we can discover some sort of unity or reduce them to some general canon.

(Ibid.: 49, emphasis added)

Therefore, experiments need to be part of a system, a general arrangement articulating uniformity among variety, in order to achieve the aesthetic standards claimed by Hutcheson. However, unlike the Cartesian notion of aesthetics, these aesthetic standards were grounded on common individual experiences. It must be noted that despite the other divergences on aesthetics between Hutcheson and Hume (see Moore 1976), they were both influenced by the experimental nature of Newton's method to conceive of aesthetics and science not merely as two interdependent objects but also as objects associated with experience acquired from ordinary life. It should not come as a surprise that Smith held a similar position. In what follows, it is argued that Smith's experimental method was based on similar aesthetic standards.

The role of aesthetics in Smith's writings is widely acknowledged by historians. For instance, Thomson (1965) argues that:

it is a striking feature of Smith's system of science that he more frequently refers to his own standard of judgement as aesthetic than as strictly rational, and that as his final criterion of truth he is willing to 
accept neither the rational test of consistency nor the empirical standard of correspondence with the observed facts.

(Ibid.: 219, emphasis added)

The importance of aesthetics and of its relation with science is discussed by Smith in several of his writings. In one of the most famous references to the importance of aesthetic qualities in theoretical systems he refers to 'The beauty of a systematic arrangement of different observations connected by a few common principles' (Smith 1776: V.i.f.25). In another often quoted passage, in his essay Of the Imitative Arts, he compares the aesthetic qualities of systems of thought with those of music, when he claims that:

In the contemplation of that immense variety of agreeable and melodious sounds, arranged and digested, both in their coincidence and in their succession, into so complete and regular a system, the mind in reality enjoys not only a very great sensual, but a very high intellectual pleasure, not unlike that which it derives from the contemplation of a great system in any other science,

(Smith undated: II.30)

In Smith's Lectures on Rhetoric and Belles Lettres (1762-63) we find his defence of a conception of discourse that he calls the 'didactick stile'. According to it, arguments must be organised so as to put before us 'both sides of the question in their true light, giving each its proper degree of influence, and has it in view to perswade no farther than the arguments themselves appear convincing' (ibid.: i.149). A historian assumes the character of a 'didactick writer' when he compares 'the evidence that is brought for the proof of any fact and way the arguments on both Side[s]' (ibid.: ii.14), maintaining impartiality in his narration through the use of a plain, neat, clear, simple, concise and direct style of discourse, which aims at avoiding ambiguity and pursues a just and natural order of expression of ideas. For Smith, there is a close link between the procedure of thought suggested by the 'didactick stile' and aesthetics. According to him, the beauty of language comes from using words that properly express the thing to be described, conveying the sentiment of the author and producing an agreeable sense to others (ibid.: i.v.56-7 and i.96) and not from the figures of speech used to deliver it. The most beautiful passages, as Smith puts it (ibid.: i.73), 'are generally the most simple'.

Smith tells us that this is the method of the 'plain man' who gives his opinion bluntly, considering evident and plain his reasons for his doings (ibid.: i.85-6). And that this is also the method of Jonathan Swift, whose 'easy and plain writing', free of parentheses and superfluous words, conveys ideas with a precision and property that they 'flow naturally upon our mind' (ibid.: i.10). In contrast are the rhetoric and ornamental 
method of Lord Shaftesbury, whose style, 'removed from the common manner', abundant in figures of speech, promotes a distortion of arguments in order to persuade the public.

It is appropriate to observe that while historical discourses have something of the character of the didactic style (see Skinner 1996: 21 and ii.14), they are not expected, according to Smith, to make use either of the oratorical or of the didactic style, for the simple fact that it is not the business of a historian to bring proofs for propositions but to narrate facts (Smith 1762-63: ii.39). Similarities between historical and didactic compositions emerge from their (1) respect for the common order of ordinary discourse (ibid.: ii.31, ii.v.39) and (2) observance of the same aesthetic rules concerning simplicity and impartiality (ibid.: ii.43, ii.65). Apart from that, the didactic style is best suited to 'all matters of science', applied either through the Aristotelian method (going over different branches in the order they appear and giving new different principles which are then used to explain and connect several phenomena) or the Newtonian method (laying down few principles which are then used to explain and connect several phenomena), which Smith praises for its 'great superiority' in being the 'most philosophical' and 'vastly more ingenious and engaging' of all methods (ibid.: ii.133-5). The Newtonian method is considered by Smith as the best vehicle for the didactic style because it favours scientific progress with its plain, concise, proper and direct argumentation. It might be said that Smith's didactic style serves the purpose of scientific discourse because it is based on the common sense of mankind.

\section{Conclusion}

Let's take stock. The experimental method developed by Newton was selectively assimilated into moral philosophy. As far as the notion of experiment (and experimental philosophy) referred to 'in harmony with (common) experience', it was retained in Hume's and Smith's experimental method. On the other hand, to the extent that this notion approached the method developed by Newton in his Opticks, it was considered inadequate as a foundation of experimental method in the social sciences. The first section of this chapter examined other dimensions involved in Newton's use of the experimental method and some characteristics of his experimental philosophy, focusing on the complementarity between common sense and aesthetics. The second section examined briefly how David Hume adapted Newton's notion of experiment to moral philosophy and how Adam Smith appears to have sided with Hume on the interpretation of the experimental aspects of Newton's philosophy. 'Experiment' becomes for Hume and Smith a reference to a concrete illustration of a system of thought. The last part of the argument revisited the role of aesthetics for Smith, contextualising it as a principle of assessment of experiments, theories or facts. It is important to note that 
the features of Smith's experimental method that have been discussed here seem to constitute the foundations of the Wealth of Nations - to the extent that it can be represented by the principle of the division of labour.

Smith sets forth the division of labour as a familiar and well known principle. He elaborates on this principle through several particular examples, appearing to assume occasionally the role of a natural philosopher. It might even be suggested that the famous example of the pin factory resembles a crucial experiment 'à la Newton' when Smith argues that (1776: I.3) 'To take an example, therefore, from a very trifling manufacture; but one in which the division of labour has been very often taken notice of, the trade of a pin-maker.' He reports to have seen a small manufactory of the kind he describes (even suggesting that he is accustomed to visit such manufactures, ibid.: I.8) and argues that the principle of division of labour can be applied to other arts and manufactures as well as to other countries' industries. (Some examples concerning Poland, France and England help him to make his case, ibid.: I.4.)

He also comments that the division of labour applies to "the trade of philosophy or speculation' (ibid.: I.9). It is difficult to imagine any other reason for providing so many examples and circumstances in which the division of labour applies other than trying to convince the reader that this principle is part of individuals' everyday experience. It is within this process of analysis that Smith conflates Newton's concept of experiment and experience into a general argument for the pervasiveness of the division of labour in his time. He points out: 'Observe the accommodation of the most common artificer or day-labourer in a civilized and thriving country, and you will perceive that the number of people of whose industry a part, though but a small part, has been employed in procuring him this accommodation, exceeds all computation' (ibid.: I.11). By describing a sort of multiplier chain of division of labour, the message he wants to convey is of unity among variety. In addition to the common sense grounds, he aims to provide the aesthetic standard of simplicity and unity of principle (in this case the division of labour) to describe a diversity of complex phenomena. This reading seems to be confirmed by Smith's remarks on the contrasts between the simple manner that people's needs are accommodated and the complex processes behind the division of labour. After a description of the variety of things needed to serve the normal conveniences of workmen, Smith argues that:

if we examine, I say, all these things, and consider what a variety of labour is employed about each of them, we shall be sensible that without the assistance and co-operation of many thousands, the very meanest person in a civilized country could not be provided, even according to, what we very falsely imagine, the easy and simple manner in which he is commonly accommodated.

(Ibid.: I.11) 


\section{Flavio Comim}

Smith avoids, just like Newton, the discussion of the metaphysical status of the causes behind the division of labour. He puts forward the principle of the 'propensity to truck, barter, and exchange one thing for another' in a similar way to that in which Newton advocates the existence of the power of gravity. He suggests that:

Whether this propensity be one of those original principles in human nature, of which no further account can be given; or whether, as seems more probable, it be the necessary consequence of the faculties of reason and speech, it belongs not to our present subject to enquire. It is common to all men, and to be found in no other race of animals, which seem to know neither this nor any other species of contracts.

(Ibid.: II.2, emphasis added)

Following the synergy between common sense and the experimental method of providing examples - in order to convey a sense of familiarity to this principle - he emphasises how 'most dissimilar characters', such as a philosopher and a common street porter, also exhibit such disposition to exchange (ibid.: II.4). It must be remembered that it is as a result of these simple principles - which he suggests are familiar and pervasive that the different progress of opulence in different nations may be explained (ibid.: III.1).

To conclude, it might be said that Adam Smith's notion of experiment seems to have been much influenced both by the Scottish common sense philosophy and by Newton's experimental philosophy (including Hume's views). It comprises: (1) a notion of common sense seen as a way of emphasising the role of reason and judgement in the conceptualisation of phenomena and producing theory with pragmatic and aesthetic content; (2) a psychological account of experiments, provided by Hume, according to which, experiments should better be seen as 'a cautious observation of human life', as it appears 'in the common course of the world'; (3) an esprit systématique, through which a variety of experiments are arranged based on few principles; (4) an evaluation criterion of these systems of thought based on their aesthetic qualities, in particular those related to experience and the Hutchesonian principle of 'uniformity among variety'; (5) an emphasis on the role of exemplifications as proxies in moral philosophy for the experiments in natural sciences, understood as a reference to a concrete illustration of a system of thought and (6) selective use of historical and empirical information. At a more concrete level, the interaction between common sense, aesthetics and the experimental methodology was used by Smith as a guide for choosing theoretical concepts based on their degree of psychological familiarity, using the 'didactic style' to promote continuity between scientific and ordinary knowledge. 


\section{Notes}

1 Reid's view of Hume's philosophy was heavily influenced by the wider context of eighteenth-century Ireland and Scotland and the pioneering works of Francis Hutcheson and George Berkeley. Hutcheson's social philosophy of common sense is very much alive in Thomas Reid's works. Reid criticises philosophers for their excessive faith in reason and dismissive attitudes towards ordinary beliefs that guide 'the credulity of the vulgar' (see Reid 1764: 7).

2 Wightman (1975: 61) notes that 'it is sometimes forgotten that the seventeenthcentury mind - unlike that of Smith's day - was at least as deeply concerned with theology as it was with the "new experimental philosophy".'

3 Moore (1976) observes that Hume's use of the Newtonian experimental method in moral subjects was motivated by an attempt to remedy the neglect of experience in moral philosophy, 'transmitted by Antiquity'.

4 Hutcheson is evidently inspired by the aesthetics contained in Newton's Principia, because he remarks that 'In the search of nature there is the like beauty in the knowledge of some great principles or universal forces from which innumerable effects do flow. Such is gravitation in Sir Isaac Newton's scheme' (Hutcheson 1725: 50, emphasis in original).

\section{References}

Campbell, R. H. and Skinner, A. S. (1976) 'General Introduction' to Smith ([1776] 1976), pp. 1-60.

Campbell, T. D. (1975) 'Scientific Explanation and Ethical Justification in the Moral Sentiments', in A. S. Skinner and T. Wilson (eds), Essays on Adam Smith, Oxford: Clarendon Press.

Cantor, G. (1989) 'The Rhetoric of Experiment', in D. Gooding, T. Pinch and S. Schaffer (eds), The Use of Experiment, Cambridge: Cambridge University Press.

Cassirer, E. (1951) The Philosophy of the Enlightenment, Princeton NJ: Princeton University Press.

Cohen, I. B. (1972) 'Introduction to the Reprint Edition', in H. Pemberton ([1728] 1972).

— (1995) 'Newton's Method and Newton's Style', in I. B. Cohen and R. Westfall (eds) Newton, New York and London: Norton.

Davie, G. (1976) 'Berkeley, Hume, and the Central Problem of Scottish Philosophy', in D. Norton, N. Capaldi and W. Robertson (eds), McGill Hume Studies, San Diego CA: Austin Hill Press.

Descartes, R. ([1637] 1984) 'Discourse of Method', in The Philosophical Writings, translated by J. Cottingham, R. Stoothoff and D. Murdoch, Cambridge: Cambridge University Press.

Dow, A. C., Dow, S. C. and Hutton, A. (1997) 'The Scottish Political Economy Tradition and Modern Economics', Scottish Journal of Political Economy 44, 4: 368-83.

Dow, S. C. (1987) 'The Scottish Political Economy Tradition', Scottish Journal of Political Economy 34, 4: 335-48.

Gower, B. (1997) Scientific Method: an Historical and Philosophical Introduction, London: Routledge.

Hollander, S. (1979) 'Historical Dimension of The Wealth of Nations', in J. O'Driscoll (ed.), Adam Smith and Modern Political Economy: Bicentennial Essays on The Wealth of Nations, Ames IA: Iowa State University Press. 


\section{Flavio Comim}

Hume, D. ([1739] 1978) A Treatise of Human Nature, edited by L. A. Selby-Bigge, 2nd edn by P. H. Nidditch, Oxford: Clarendon Press.

Hutcheson, F. ([1725] 1973) An Inquiry Concerning Beauty, Order, Harmony, Design, edited by P. Kivy, The Hague: Martinus Nijhoff.

Kivy, P. (1973) 'Introduction' to Hutcheson ([1725] 1973).

Lindgren, J. R. (1969) 'Adam Smith's Theory of Inquiry', Journal of Political Economy, 77: 897-915.

Macfie, A. (1955) 'The Scottish Tradition in Economic Thought', Scottish Journal of Political Economy 2, 2: 81-103.

— (1967) The Individual in Society: Papers on Adam Smith, London: Allen \& Unwin.

MacLaurin, C. ([1748] 1775) An Account of Sir Isaac Newton's Philosophical Discoveries, in Four Books, 3rd edn, London.

Marshall, A. ([1890] 1961) Principles of Economics, 9th edn (variorum), London: Macmillan.

Moore, J. (1976) 'The Social Background of Hume's Science of Human Nature', in D. Norton, N. Capaldi and W. Robison (eds), McGill Hume Studies, San Diego CA: Austin Hill Press.

Morrison, M. C. (1998) 'Experiment', in E. Craig, Routledge Encyclopedia of Philosophy, London: Routledge.

Newton, I. ([1687] 1934) Mathematical Principles of Natural Philosophy, translated by A. Motte, Berkeley CA and Los Angeles CA: University of California Press.

- ([1704] 1979) Opticks, or A Treatise of the Reflections, Refractions, Inflections and Colours of Light, based on the 4th edn of 1730, New York: Dover Press.

Pemberton, H. ([1728] 1972) A View of Sir Isaac Newton's Philosophy, New York and London: Johnson Reprint Corporation.

Raphael, D. D. and Macfie, A. L. (1976) 'Introduction' to Smith ([1759] 1976), pp. 1-52.

Raphael, D. D. and Skinner, A. S. (1978) 'General Introduction' to Smith ([1795] 1980), pp. 1-27.

Redman, D. A. (1997) The Rise of Political Economy as a Science: Methodology and the Classical Economists, Cambridge MA: MIT Press.

Reid, T. ([1764] 1983) An Inquiry into the Human Mind on the Principles of Common Sense, in R. E. Beanblossom and K. Lehrer (eds), Inquiry and Essays, Indianapolis IN: Hackett.

([1785] 1983) Essays on the Intellectual Powers of Man, in R. E. Beanblossom and K. Lehrer (eds), Inquiry and Essays, Indianapolis IN: Hackett.

Ross, I. S. (1995) The Life of Adam Smith, Oxford: Clarendon Press.

Russell, B. ([1961] 1991) History of Western Philosophy, London: Routledge.

Skinner, A. S. (1996) A System of Social Science: Papers relating to Adam Smith, 2nd edn, Oxford: Clarendon Press.

— (1972) 'Adam Smith: Philosophy and Science', Scottish Journal of Political Economy 29, 3: 307-19.

Smith, A. ([1759]1976) The Theory of Moral Sentiments, Glasgow Edition, edited by D. D. Raphael and A. Macfie, Oxford: Oxford University Press.

— ([1762-3] 1983) Lectures on Rhetoric and Belles Lettres, Glasgow Edition, edited by J. C. Bryce, Oxford: Oxford University Press.

— (1776] 1976) An Inquiry into the Nature and Causes of the Wealth of Nations, Glasgow Edition, edited by R. H. Campbell and A. S. Skinner, Oxford: Oxford University Press. 
— ([1795] 1980) 'The History of Astronomy', in Essays on Philosophical Subjects, Glasgow Edition, edited by W. Wightman and J. C. Bryce, Oxford: Oxford University Press.

— ([undated] 1980) 'Of the Imitative Arts', in Essays on Philosophical Subjects, Glasgow Edition, edited by W. Wightman and J. C. Bryce, Oxford: Oxford University Press.

Somerville, J. (1987) 'Reid's Conception of Common Sense', Monist 70: 418-29

Summers, D. (1987) The Judgement of Sense: Renaissance Naturalism and the Rise of Aesthetics, Cambridge: Cambridge University Press.

Thomson, H. F. (1965) 'Adam Smith's Philosophy of Science', Quarterly Journal of Economics 79: 212-33.

Voltaire ([1738] 1967) The Elements of Sir Isaac Newton's Philosophy, London: Hanna, Frank Cass.

Wightman, W. (1975) 'Adam Smith and the History of Ideas', in A. S. Skinner and T. Wilson (eds), Essays on Adam Smith, Oxford: Clarendon Press. 


\title{
8 James Mill as economist \\ Theory dominated by deductive method
}

\author{
Thomas S. Torrance
}

James Mill was born on 6 April 1773 in North Water Bridge, a village on what is now the A94 trunk road and which is situated half-way between the Angus town of Brechin to the south and the Kincardine town of Laurencekirk five miles to the north (The Royal Mail treats the latter as the postal town address of the village.) North Water Bridge is also approximately six miles north-west of the Angus coastal town of Montrose.

His father, also James, though born with the family name of Milne, was a shoemaker and small businessman. Both James senior and his wife Isabel Fenton believed in education as an effective means of self-improvement and strongly supported the young James in his early studies, first at the local village school and then at Montrose Academy.

In 1790, with the support of Sir John and Lady Jane Stuart, who were friends of the Mill family, Mill was encouraged to continue his education at the University of Edinburgh. Sir John was a Baron of the Exchequer in Scotland and owned an estate at the nearby village of Fettercairn, and from this period onwards he saw himself as Mill's sponsor and mentor. And indeed, while a student, Mill lived in the Stuarts' town house in Edinburgh.

Mill spent eight years at the University of Edinburgh. His original career plan was the Church of Scotland ministry. To this end, after taking traditional arts courses in Greek, Latin and Moral Philosophy (this last subject was studied under Dugald Stewart, 1753-1828, a dominant figure of the common sense school of philosophy), Mill devoted himself to studying Divinity from 1794. In 1798 he was formally licensed as a preacher by the then presbytery of Brechin (today both Brechin and North Water Bridge are within the Kirk's presbytery of Angus).

Mill's interest, however, in theology and in the Church of Scotland waned, and in 1802 he decided to break decisively with his past and to leave Scotland. In the company of Sir John Stuart, who was travelling south for a parliamentary session, Mill departed for London to start a new career as a journalist. Following his departure, Mill was never to set foot in Scotland again. Initially in London he was employed by the Anti-Jacobin Review, and then, a year later, was appointed editor of the Literary Journal. 
Mill married Harriet Burrow in 1805 and in the following year their first child was born, a son they named John Stuart in honour of his old patron from Scotland. In the year of John Stuart's birth Mill started a task that was to continue until 1818, namely writing the volumes of his History of British India. On the success of this work he came to be employed in 1819 at India House by the East India Company (which at that time and until its legal dissolution in 1858 governed India under authority of its parliamentary charter) as an examiner of its correspondence and despatches. This well paid employment, which finally ended Mill's earlier financial worries, continued until the year of his death in 1836 .

In 1808 Mill's friendships began with the utilitarian philosopher and legal reformer Jeremy Bentham (1748-1832) and the stockbroker economist David Ricardo (1772-1823), and both associations, in their different ways, profoundly shaped Mill's intellectual development. His friendship with Bentham was particularly influential, and Mill even moved his residence in London in order to be situated closer to him. Largely owing to his contact with Bentham, Mill came to abandon the 'Scottish' ethical intuitionism of Dugald Stewart and his school, and to embrace wholeheartedly the 'English' utilitarian outlook, which rooted ethics in the teleological 'greatest happiness principle'. The close personal friendship with Bentham led Mill to join him in public criticism of traditional legal conventions in the name of social improvement. Mill's many contributions in the 1810s on social and legal issues to the Edinburgh Review and to the reformist political magazine the Philanthropist are testimony to his growing political radicalism.

Mill's friendship with David Ricardo was largely responsible for the growth of his interest in political economy as a distinct 'science'. Mill gave encouragement to Ricardo to publish a compilation and expansion of his many previous economic writings, which duly appeared as his Principles of Political Economy and Taxation in 1817. In return Mill was urged by Ricardo to publish his own views on political economy. Mill's work originated as notes used to instruct his son John Stuart in the subject but emerged as a published book in 1821 under the title Elements of Political Economy. ${ }^{1}$ We shall examine in greater detail two of the important topics of this book later on in this chapter.

Between 1816 and 1823 Mill wrote a total of ten articles for the Supplement to the 5th edition of the Encyclopaedia Britannica. These articles embraced various topics in the fields of government, jurisprudence and education, the most influential being the one on 'Government' of 1820 . These articles were separately reprinted in 1828 and, in light of the reliance by them on utilitarianism as the underlying philosophical basis of analysis, were applauded as essential reading by political and philosophical radicals well into the middle of the century. And largely on account of these articles, Mill in his later life came to be publicly perceived as the best known expounder and disciple of the Benthamite 'religion'. It should be 
noted, however, that, taking a longer view, the best known statement of this outlook is held not to be anything written by James Mill, but by his eldest son John Stuart Mill (1806-73). J. S. Mill's essay 'Utilitarianism' of 1863 is today held to be the prime exposition of this type of moral philosophy, and indeed it must be one of the most intensively studied and enduring philosophical works of all time.

From 1820 onwards until the year of his death, Mill, in the pages of the Westminster Review and other media such as the issued public statements of the Political Economy Club which he co-founded in 1823, devoted himself more or less continuously to social reform, including reform in the area of education (in which he considered himself an expert, having been involved in the home education of all his nine children, most notably that of John Stuart). The climax to the reformists' efforts occurred in June 1832 with the passing into law of the great Reform Act. With its abolition of the 'rotten boroughs' and extension of the franchise, the Act started a democratic constitutional process which made it eventually possible for serious consideration of the utilitarian agenda to become practical politics.

Mill's interests also extended to psychology and the nature of the human mind, and his mature views in this area are represented by his book Analysis of the Human Mind, published in 1829. A chief thesis here is that there are 'no innate principles in the mind' (Locke 1690: $67 \mathrm{ff}$.), to use the phrase of John Locke (1632-1704), not even of an organisational or conceptualising kind: all knowledge comes from what is empirically experienced. From this starting point, Mill established his views on education and his recommendations for educational reform.

It is interesting to note that Locke's 'empirical' theory of knowledge, to which Mill adhered in the years after his youth, differed greatly from the 'intuitionist' claims of the common sense (i.e. common judgement) school of philosophy which Mill had encountered while an undergraduate at Edinburgh University. In contrast, this school, founded by the Church of Scotland minister and philosopher Thomas Reid (1710-92), argued that 'all knowledge, and all science, must be built upon principles that are self-evident' and that 'the same degree of understanding which makes a man capable of acting with common prudence in the conduct of life, makes him capable of discovering what is true and what is false in matters that are self-evident, and which he distinctly apprehends' (Reid 1785: 559).

James Mill died at his London home on 23 June 1836. As one of the figures whose thought was responsible for shaping the pattern of British social culture in the later part of the nineteenth century, albeit in many ways indirectly via the philosophical and political writings of his much better known eldest son, his influence stretched beyond the grave. 


\section{Mill's deductivist methodology}

As we have already observed, in 1821, with the encouragement of David Ricardo, Mill published his Elements of Political Economy, a closely argued work of admirably modest length at just over 300 pages. The second edition, which appeared in 1823, and the third of 1826 contain only minor alterations, most of which are merely verbal. From the start Mill acknowledges that he is not an original or pioneering thinker. In the preface, where he describes his work as a 'school-book of Political Economy', he says, 'I profess to have made no discovery.' His aim, rather, is to present to 'persons of either sex of ordinary understanding' what he takes to be 'the essential principles of the science' and 'to state the propositions clearly and in their logical order'. With historical hindsight this objective is achieved. The worth of Mill's book to contemporary students of the evolution of economic thought is that it is a genuinely clear and non-verbose account of what a leading economic thinker, though with a distinctive deductive methodology, considered the chief doctrines and explanatory abilities of political economy just under half a century from Adam Smith's Wealth of Nations of 1776.

In the Elements Mill habitually refers to political economy as a 'science' and it is clear that by this word he understands more than the Latin scientia, or knowledge in general. He says in the book's introduction that political economy involves 'four inquiries' into the 'laws' of production, distribution, exchange and consumption. The use of the word 'law' rather than an expression like 'general principle' points to Mill's methodological framework, which is implicit rather than stated explicitly in this book. Nowhere in Mill is there any attempt, like a logical-empiricist philosopher of the 1950s, to produce a physicalist elimination of all concepts that imply consciousness (such as 'purpose', choice' or 'meaning') in favour of concepts that imply nothing but physical causality. What he does seek, however, is a type of nomological or law-based knowledge that stems ultimately from psychological laws, about social and economic relations. In the Elements Mill's preferred method is abstract and involves deduction from what he understands to be self-evident general axioms about human nature.

Mill's methodological stance is more overtly discussed in his Essay on Government (1820), to which reference has already been made. After stating that 'government is a question about the adaptation of means to ends' and that the appropriate end is to secure 'the greatest happiness of the greatest number' (ibid.: 47), Mill then, in the fourth paragraph of the essay, proceeds to assert that 'the whole science of human nature must be explored to lay a foundation for the science of government' (ibid.: 48). The reason for this is that 'to understand what is included in the happiness of the greatest number, we must understand what is included in the happiness of the individuals of whom it is composed' (ibid.: 48). This 
rigorously analytical approach to explaining social events is the method adopted in the Elements, where the social phenomena are economic in nature.

Mill's analytical method can be seen even more explicitly if we assume, as is reasonable, that the views of John Stuart Mill reflect those of his father on this topic. I refer here to Book VI, entitled 'The Logic of the Moral Sciences', of John Stuart's book System of Logic of 1843. John Stuart writes that 'all phenomena of society are phenomena of human nature' (ibid.: 572) and that 'the laws of the phenomena of society are, and can be, nothing but the laws of the actions and passions of human beings united together in the social state' (ibid.: 573). He then continues by claiming that 'human beings in society have no properties but those which are derived from, and may be resolved into, the laws of the nature of individual man' (ibid.: 573).

This methodological stance, while not being an early precursor of midtwentieth-century physicalism, does, however, involve a 'reductionist' programme of its own, namely the reduction in explanations of what is social by nature to explanations that refer purely to the psychological attributes of individuals. Incidentally, neither father nor son Mill ever relates what actually comprises these 'laws of human nature' from which so much of importance is supposed to follow.

The conviction that seeks to deduce social and economic explanations from 'the laws of the nature of individual men', and that also urges a reconstruction of social institutions based on what these laws imply, is in contrast to the more empirical and historically aware approach to understanding society favoured by the premier figures of the eighteenth-century Scottish Enlightenment, especially Thomas Reid (previously mentioned), David Hume (1711-76), Adam Smith (1723-90) and Adam Ferguson (1723-1816). A key aspect of what I am calling the more historical approach is an appreciation of the evolutionary nature of human society and of the fact that many individual phenomena and institutions exist not because of any conscious plan or intent but rather as, in the words of the twentieth-century Austrian economist and philosopher F. A. Hayek (1899-1992), the 'result of human actions, but not of human design' (1967: $96 \mathrm{ff}$.). In other words, to attempt to explain society on the basis of theories derived by deduction from the 'laws of human nature' involves a quite different approach and attitude from that which is willing, where appropriate, to explain the existence and continued functioning of social institutions as the unintended and often unpredictable repercussions of the interaction of many people's actions that are consciously directed towards other ends. In the famous passage in the Wealth of Nations that refers to the 'invisible hand' (IV, ii, 9), Smith is recognising that that most useful of social phenomena, the price mechanism, is not to be explained as if it had been consciously constructed according to a blueprint deduced from some set of psychological laws, but is an organic-like phenomenon 
that arose more or less spontaneously, as an unintended consequence of behaviour directed to achieving other objectives. 'Every individual,' Smith writes on this matter, 'intends only his own gain, and he is in this, as in many other cases, led by an invisible hand to promote an end which was not part of his intention' (ibid.).

To explain a social or economic event or condition as an unintended result of seemingly unconnected human behaviour is a valuable and genuine addition to societal knowledge. For instance, using the concept of 'unintended consequence', wars can be explained even though the actors involved are not personally aggressive and do not necessarily seek conflict, episodes of high unemployment can be explained without assuming people to be naturally lazy, etc. Of course, we must add, to allow the concept of 'unintended consequence' to be a methodologically acceptable concept in possible explanations of the emergence and continuing functioning of certain social institutions is not to adopt a reactionary antireform position and hold that such institutions 'therefore' cannot be improved by conscious action. Indeed, the opposite is the case: to reform effectively the working of an institution like the market price mechanism, requires a correct understanding of how it actually functions at the moment.

To return to Mill's Elements, there is nothing in this work that indicates the author appreciates the value of being able to use, when occasion suits, the concept of 'unintended consequence' in the course of social and economic explanation. Mill's methodological orientation can be described as highly 'rationalistic'. It is to treat social and economic theory as something rather like two-dimensional Euclidean geometry: you start from certain secure axioms and then you proceed by deduction. This methodological approach, to repeat, is very different from the more empirical and organic method of social inquiry associated with the leading figures in this field in eighteenth-century Scotland.

A claim strongly and insistently stressed by Karl Popper (1902-94), one of the most insightful philosophers of science of the twentieth century, is that for any sort of systematic inquiry a theory of some kind, if only just at the rudimentary level of a tentative proto-hypothesis, is inescapably needed (1963: $46 \mathrm{ff}$.). First, because without some criteria of discrimination there can be no relevant facts. 'Facts' aren't natural objects like coloured pebbles on a beach lying around just waiting to be picked up or discovered. A fact, that is, the content of what is asserted by a true proposition, exists only in relation to some conception of what is held to be 'relevant'. Without a theory we wouldn't know what to look for within a chosen area of reality: in this sense, facts are always 'theory-laden'. But to say this is not to assert that theories conjure facts out of nothing, for there may well be no facts that conform to the criteria of relevance defined by the particular theory in question. Although a theory is required to identify facts, once we have the identifying criteria, whether or not there are facts 
of the relevant kind is an empirical matter. And second, a theory is required in systematic enquiry as a necessary condition of being able to distinguish a causal or functional connection from a coincidental one. Like the position with facts, a theory doesn't invent causal connections. It hypothesises such a connection in an area of reality, and one of the tasks of an enquirer is to subject this claim to test. It may well be of course that a theory is mistaken in supposing two or more variables to be functionally related: this is a task for experiential tests to settle. But without a theory and its causal postulations, we would have no way of knowing whether observed instances of temporal association between events reflect causality or are merely coincidence.

Theories of some kind, then, are always required for explanatory enquiry. But there is no scientific or philosophical necessity for a theory of the social world to be a deductive system that stems from a small tightly knit set of self-evident foundational premises. In distinction from this view, a good social theory can consist of any number of components, making use between them of a large number of concepts of different kinds, some social and some no doubt psychological. The methodological difference between James Mill and, say, Adam Smith is not that the former employs a theory while the latter doesn't. But rather, the difference is that the theory employed by the former is avowedly from a small number of premises that are all of the same type (the laws of human nature) while, with the latter, no aspiration to such axiomatic frugality is advanced or even considered to be meritorious. In the latter case, enquiry is guided by a theory composed of a wide and heterogeneous collection of freestanding individual hypotheses, each held on account of its deemed ability to contribute to the explanatory power of the theory as a whole. In any case, the truly critical property of an explanatory theory in any area of investigation is not how it is internally structured but how well the entire theory stands up to empirical testing.

Taking Mill's methodological approach at its face value, it's illuminating to ask whether the claim that economic theory should be deduced from the 'laws of the nature of individual men' is intrinsically credible. The prescriptive injunction 'should' obviously makes sense in this context only if economic theory could be so deduced. But could it?

The process of logical deduction from axioms makes explicit the information content that is already implicit in the set of premises involved. Let's give a simple example. Suppose we take the premises 'All tigers are cats' and 'All cats are felines', then with validity we are entitled to assert the conclusion 'All tigers are felines'. We can then debate whether 'Some tigers are felines' and 'Some felines are tigers' can also be validly deduced from the given premises. Modern logicians would probably dispute that the last two conclusions are validly established from the premises (on the ground that the premises could be true even if there were no existent tigers, cats or felines, and that since a conclusion involv- 
ing the word 'some' implies existence, it must be invalid to deduce existence from non-existence). Anyway, at least there could be a sensible argument on this point! But suppose now we are presented with the claim that the conclusion 'All foxes are canines' can be deduced from the original premises. Well, there cannot be much of a discussion here: since the premises don't contain the concepts 'fox' and 'canine', it's indisputable that it's impossible validly to deduce any such conclusion. And this remains the case even if we should be allowed the whole of eternity to make the attempt!

However, a manoeuvre of precisely this kind is what is proposed in Mill's axiomatic approach that starts with the 'laws of the nature of individual men'. If you start with purely psychological premises, a conclusion involving social concepts like 'economy' or 'government' cannot possibly be deduced. It cannot possibly be deduced for exactly the same reason that our 'fox' conclusion could not possibly be deduced from the suggested premises above. In other words, if you want a deductive economic theory, then premises involving social concepts must, of necessity, be involved. A methodological approach that literally and strictly bases itself on the reductionist notion that 'human beings in society have no properties but which are derived from, and may be resolved into, the laws of the nature of individual men' can only end as an unworkable failure.

Some philosophers, including Karl Popper in his book The Poverty of Historicism of 1957 (with a second edition of 1960), argue further that a reductionist programme which attempts to explain the social in terms of the psychological cannot succeed for the straightforward reason that the concept of 'individual' in a phrase like 'the laws of the nature of individual men' presupposes the existence of socialised human beings and thus cannot be invoked without improper question begging to explain the existence itself of society. On this particular topic, Popper, a severe critic of any sort of reductionist methodology in science, writes (ibid.: 158): 'psychology cannot be the basis of social science. It is itself just one of the social sciences: "human nature" varies considerably with the social institutions, and its study therefore presupposes an understanding of these institutions.'

From this discussion of the barriers that prevent economic theory being derivable from the laws of human nature, we can only conclude that Mill, in the development of his own economic ideas, cannot be faithful to the literal tenets of his preferred axiomatic deductive method. The fact remains, however, that he regards his method as ideal, and this, we shall argue, has stultifying consequences for his theory's ability to explain economic phenomena. We shall discuss two such cases where Mill's methodological beliefs debase the quality of his offered economic explanations.

A common feature of strict deductive reasoning is that time, except where it is denoted by its own dedicated variable in a premise, tends to play little intrinsic role. It makes little sense, after all, to say that premises 
deductively imply a conclusion after a time gap. Deduction, a quasi-mathematical operation, is inherently a timeless drawing out of logical implications. It is therefore perhaps unsurprising to find that a salient feature of Mill's Elements is an almost complete lack of attention to the significance of time sequencing in economic affairs. I indeed would venture the opinion that this lack of interest in the crucial role of time in economic processes runs like a geological fault line throughout Mill's attempts to explain events by means of the theory expounded in the Elements.

\section{Mill's critique of Hume}

The first illustration of this problem in Mill I wish to dissect is in chapter III, section xii ('Inconveniences to which the use of paper money is liable'), which, as the title suggests, discusses a number of the attributes of paper money. In the Elements Mill hardly ever refers to previous or contemporary economic writers (he himself draws attention to this fact in the preface), but in this section he does mention Hume by name. Mill gives no textual reference, but it is not difficult to discern that what has displeased him is an argument in Hume's essay 'Of Money'. This essay appeared in a book of essays entitled Political Discourses published by Hume in 1752.

Hume, basing his argument on the doctrine that today we know as the Quantity Theory of Money, seeks to explain the fact that when an expansion of the money stock starts, the first perceived effect is an increase in output and production in some area of the economy. In Hume's own words:

$[\mathrm{W}] \mathrm{e}$ find that, in every kingdom into which money begins to flow in greater abundance than formerly, everything takes a new face: labour and industry gain life; the merchant becomes more enterprising, the manufacturer more diligent and skilful, and even the farmer follows his plough with greater alacrity and attention.

(Hume 1752: 286)

Hume says that it is not easy to account for this situation, in view of the fact that the eventual influence of a 'greater abundance of coin' is a 'heightening [of] the price of commodities'.

And again in his own words, Hume continues:

To account, then, for this phenomenon, we must consider that though the high price of commodities be a necessary consequence of the increase of gold and silver, yet it follows not immediately upon that increase; but some time is required before the money circulates through the whole state and makes its effect be felt by all ranks of people. At first, no alteration is perceived; by degrees 
the price rises, first of one commodity, then of another; till the whole at last reaches a just proportion with the new quantity of specie which is in the kingdom. In my opinion, it is only in this interval or intermediate situation, between the acquisition of money and rise of prices, that the increasing quantity of gold and silver is favourable to industry.

(Ibid.: 286)

Modern economists would no doubt add to this explanation by saying that it assumed an initial condition of near but not full employment and also a stable asset demand for money. A present-day explanation would also probably wish to refer to the possible role of money illusion and to the price expectations of the various actors involved. But these are mere quibbles: Hume's explanation, with its perceptive analysis of the role of the time sequencing of the key links in the episode described, is nothing short of extraordinary for the mid-eighteenth century.

Remarkable though Hume's explanation is, it receives short shrift from Mill, who rejects it completely. After providing a fair summary of Hume's argument, Mill comments as follows:

This doctrine implies a want of clear ideas respecting production. The agents of production are the commodities themselves, not the price of them. They are the food of the labourer, the tools and machinery with which he works, and the raw materials which he works upon. These are not increased by the increase of money: how then can there be more production? This is a demonstration that the conclusion of Hume is erroneous. It may be satisfactory to unravel the fallacy of his argument.

(Mill 1826: 165f.)

To demonstrate that Hume's conclusion is erroneous and his argument is fallacious, Mill presents some syllogistic reasoning of his own. Thus:

The man who goes first to market with the augmented quantity of money, either raises the price of the commodities which he purchases, or he does not.

If not, he gives no additional encouragement to production. The supposition, therefore, must be that he does raise prices. But exactly in proportion as he raises prices, he sinks the value of money. He therefore gives no additional encouragement to production.

(Ibid.: 165f)

This attempted refutation of Hume gives a clear indication of what is wrong with Mill's methodological approach to economic explanation. By treating economic analysis as pure static deduction, the conception that 
what he is trying to explain are episodic events in time eludes Mill completely. Hume's main point is that initially the first to spend the increase in money raises the relative price of what is being purchased, that is, raises the price of what is being purchased without simultaneously 'sinking the value of money'. It is this initial relative price rise (and implicitly assuming some spare productive capacity) that causes the observed initial increase in production which is precisely the phenomenon Hume sets out to explain. Sinking the value of money, to use Mill's phrase, occurs later, as Hume himself fully recognises. Hume also appreciates, as can be seen from the earlier quotation from the essay 'Of Money', that when in time the sinking of the value of money takes place, the original increase in the quantity of money ceases to be so favourable to industry.

Mill's Elements was published sixty-nine years after Hume's essay 'Of Money', and yet in it monetary understanding takes an enormous backward and retrograde step. The broken-backed critique of Hume arises, I suggest, because with Mill the strict deductive mode in which his theoretical analysis is cast hinders his theory from seriously entertaining the notion that time itself is frequently supremely important when seeking explanations of dynamic economic processes. With Mill, method tends to dominate theory with the result that the explanatory power of the theory is vastly impoverished.

\section{Mill's critique of Malthus}

There is a second example in the Elements that also illustrates well and supports the verdict just passed on Mill's economic theory. My reference is to Mill's dismissal as pure error the creative insights of the 'theory of gluts' of the Reverend Thomas Robert Malthus (1766-1834).

Thomas Malthus, better known for his work (to give the shortened title!) An Essay on the Principle of Population of 1798, published his Principles of Political Economy in 1820, with a posthumous second edition appearing in 1836. The Principles was published in the year following the popularly named 'massacre of Peterloo' at St Peter's Field, Manchester, in August 1819. This riotous event, during which eleven people were killed, began as a demonstration led by unemployed weavers to protest at the suspension of Habeas Corpus and other repressive measures taken by the government to control the manifestations of public unease at the hardships caused by the recession that had started in 1818. To modern eyes, this recession is seen in part as a delayed reaction to the curtailment of military spending and other adjustments to a peacetime economy that followed the ending of the Napoleonic War in 1815.

In chapter VII, sections iii to $\mathrm{x}$ (in the first edition) of his Principles Malthus offers an explanation, in general terms, of the phenomenon of recessions. The explanation is his famous 'theory of gluts'. This theory is developed to show that the view that 'there cannot possibly be a glut of 
commodities in general' is 'utterly unfounded' (1820: 353). The originator of this doctrine as an explicit theory was the French economist Jean Baptiste Say (1767-1832), who argued in his major work of 1803, (translated from French as) A Treatise on Political Economy, that a situation of general overproduction is not possible, a doctrine now called by economists 'Say's law of markets'. Malthus himself summarises Say's theory as follows:

commodities being always exchanged for commodities, one half will furnish a market for the other half, and production thus being the sole source of demand, an excess in the supply of one article merely proves a deficiency in the supply of another, and a general excess is impossible.

(Malthus 1820: 253)

To give a synopsis of what is an extended argument, Malthus asks what would tend to happen if 'capitalists' in a given production period did not employ all their proceeds of sale to purchase either goods for their own immediate consumption or goods to be used for capital accumulation. In his own reply, Malthus argues that should capitalists behave in this way (because, for instance, they perceived insufficient opportunities for profitable investment), the result would be a glut of unsold commodities, leading to a recession, a period of diminution in the overall quantity of production and the numbers in employment. Malthus's solution to gluts is to recommend (ibid.: 466) the encouragement of enhanced immediate consumption by 'landlords', the only other group in society who would have the means to undertake this course of action, in order to compensate for the shortfall in total expenditure during those periods in which the 'mercantile classes' chose to consume less than they produced.

With Malthus's theory of gluts we have a remarkable explanation that anticipates much of the development of macroeconomic analysis that occurred in the 1920s and 1930s. In the language of the present day such theory, if withdrawals from the circular flow of income exceed injections in a given period of time, the effect, ceteris paribus, in succeeding periods will be a contraction of economic activity and volume of employment. When he wrote, Malthus was, in the field of recession analysis, ahead of his time by over a century. His own policy solution to the challenge presented by the existence of recessions would, naturally, today be regarded as eccentric. But his analysis of what would now be described as shortfalls in effective demand and their role in the causation of recessions earns him a place of honour in the gallery of those who have made a creative contribution to the sum of economic understanding.

Malthus's pathbreaking contribution to economic analysis of his theory of gluts receives, however, no praise from Mill. Near the end of his own discussion in the Elements of Malthus's theory, Mill appears highly 
confident in the strength of his own position. He writes (1826: 240): 'The doctrine of the glut, therefore, seems to be disproved by reasoning perfectly conclusive.' Mill holds not only that 'consideration of this subject' often involves a 'confusion of ideas' (1826: 238), but also that it is unclear to him what Malthus's arguments actually establish. In his own words, Mill comments (ibid.: 243): 'Mr Malthus, thus, totally failing to prove a glut ... substitutes, for arguments to prove that effect, arguments to prove other effects.' What, then, is the heart of Mill's case against Malthus?

In the Elements Mill's views on consumption and his attempted rebuttal of Malthus on gluts are to be found in chapter IV, section ii ('That which is annually produced is annually consumed') and the immediately following and longer section iii ('That consumption is co-extensive with production'). Mill aspires to show that it's not just as a matter of contingent fact that general gluts do not happen, but that, as a matter of pure logic, such phenomena could not happen.

Mill, true to his professed methodological stance, begins his argument here with reference to a 'law of human nature', saying (ibid.: 228): 'it would be inconsistent with the known laws of human nature to suppose that a man would take the trouble to produce anything without desiring to have anything.' By deduction, he then establishes a 'necessary' truth, as follows:

As every man's demand, therefore, is equal to that part of the annual produce, or of the property generally, which he has to dispose of, and each man's supply is exactly the same thing, the supply and demand of every individual are of necessity equal.

(Ibid.: 231)

The stream of logical reasoning continues, thus:

But if the demand and supply of every individual are always equal to one another, the demand and supply of all the individuals in the nation, taken aggregately, must be equal. Whatever, therefore, be the amount of the annual produce, it can never exceed the amount of the annual demand. The whole of the annual produce is divided into a number of shares, equal to that of the people to whom it is distributed. The whole of the demand is equal to as much of the whole of the shares as the owners do not keep for their own consumption. But the whole of the shares is equal to the whole of the produce. The demonstration, therefore, is complete.

(Ibid.: 232)

But what of the objection that a seller might want to hoard cash with the proceeds of his sales rather than use the money to make other purchases? Mill's answer is this (ibid.: 233): 'It makes no difference to say, 
that perhaps he only wanted money; for money is itself goods; and, besides, no man wants money but in order to lay it out, either on articles of productive, or articles of unproductive consumption'. (In Mill's terminology, which he explains in chapter IV, section I, 'Of productive and unproductive consumption', 'productive consumption' is expenditure 'for the sake of something to be produced' (ibid.: 220), i.e. capital accumulation or investment; 'unproductive consumption' is expenditure 'which does not take place to the end that an income or revenue may be derived from it' (ibid.: 222), i.e. immediate consumption.)

Consider the above quotation concerning money hoarding. Although it may be true as a timeless generality that money is desired because it can be used to buy goods (associated with either productive or unproductive consumption), it does not at all follow that money is desired so that immediately upon acquisition it can be so used. In the matter of money demand, we again have another illustration of where with Mill all question of time is just surgically excised from consideration. Processes which are distinct and which can take place in temporal sequence are, typically with Mill, just assumed a priori to occur simultaneously. The penalty for this banishment of time is deformed or nonsensical theoretical explanations.

At the centre of Malthus's theory of gluts is the idea that if 'capitalists', or other parties with an income larger than is required to meet all their immediate consumption needs, should find at a particular time no profitable investment outlets, then they will, for a period, tend to retain the proceeds of their own sales in cash until such time as potentially profitable investment projects again present themselves. The general glut then occurs because of the delay in time, which could be lengthy, in undertaking (marginal) expenditures on capital investment. Malthus's argument is about what happens in time: it is emphatically not about definitions in logical arguments of the concept of 'the purposes of money'.

It is interesting to reflect that in the Wealth of Nations Adam Smith also believed that general overproduction was not possible or extremely unlikely. But with him, the reason is nothing to do with what is logically necessary but because he believed as an empirical matter that money earned by selling the outcome of productive activity that was not at once used to finance immediate consumption was rapidly spend on investment capital. In Book II, chapter iii, paragraph 18 of the Wealth of Nations we find Smith writing: "what is annually saved is as regularly consumed as what is annually spent, and nearly in the same time too; but is consumed by a different set of people'.

Smith, unlike Mill, understands that the process by which savings become, or may become, immediate consumption in the hands of those who supply investment goods to the saver takes place in time and over a period of time. Smith does not fall into the methodological trap of treating distinct phases of a causal sequence as if the different phases were 
timelessly simultaneous. It is fair no doubt to criticise Smith for making a factual mistake in holding that the time interval is always short over which savings in the hands of one set of individuals become expenditure on immediate consumption in the hands of a different set of individuals. Indeed, we might wish to go further and argue not only that this time interval is not always short, but that in reality its length is highly variable and unpredictable. However, Smith's view may have been less unreasonable in the context of eighteenth-century Scotland, when saving was confined to a small sub-set of society.

\section{Conclusion}

As this chapter has indicated, our conclusion about James Mill is that his Achilles heel as an economic thinker, as evidenced by the content of his Elements, is that his theoretical analysis isn't truly appropriate, given the subject matter he is attempting to understand, namely real-world social phenomena and their underlying generative processes. As an economic analyst Mill is deeply in thrall to a geometric-type deductive method that destructively inhibits his theories from posing the appropriate questions of the empirical phenomena and events he seeks to explain. As we have seen, especially in regard to his unappreciative critiques of Hume's monetary theory and of Malthus's theory of gluts, Mill's strict deductive method prevents his theory from accepting temporal sequencing as a key theoretical category in his explanatory analysis. With an impoverished use of the concept of time, Mill's economic explanations, though succinctly constructed in elegant logical form, fall far short of the best examples of economic analysis found in the previous century. In science generally, explanatory theories that are dominated by inadequate methodological presuppositions are invariably inadequate themselves. Mill's economic theory is no exception to this general rule.

Mill was a man who was well known and regarded in his lifetime, and for a period afterwards, as a leading intellectual political and social reformer. Long-term historical memory, however, views James Mill as perhaps being best known as the father of John Stuart Mill. But, in economics, not even John Stuart is now considered a thinker of the first rank. John Stuart's works that are read and discussed today for their contemporary relevance are his philosophical writings, especially his two essays 'Utilitarianism' of 1863 and of 'On Liberty' of 1859. Apart from John Stuart's moral and political philosophy, almost everything else written by both father and son, if read seriously at all, is studied for its historical interest and what it conveys about the intellectual concerns and attitudes of the epochs in which the two men lived.

Does James Mill belong within the Scottish tradition of enlightened thought? That tradition emphasises the civilising benefits of certain attitudes towards mortal human life and the society in which that life flour- 
ishes. Among these attitudes are: a conception of men and women as free moral agents, fully responsible for their own choices and actions; a deep belief in natural liberty, natural justice and limited government; sensitivity to, and toleration of, the philosophical assumptions behind the thought patterns of others; recognition of the importance of understanding the historical origin of both intellectual ideas and social institutions; a quiet determination to make life better in any aspect by adapting rather than destroying what has organically evolved; and an acute aversion to iconoclastic rationalist ideologies in any shape or form.

Undeniably Mill was a Scot by birth, and while an Arts and then Divinity student at the University of Edinburgh in the 1790s he was immersed in the ideas of the Scottish Enlightenment as it existed during its final decade as a recognisably distinct cultural movement (though a number of noted individuals, such as Sir William Hamilton, 1778-1856, continued the tradition in their own person). However, after Mill left Scotland in 1802 there is little to indicate that he treasured the essentials of the Scottish tradition or that he ever considered himself to be in any meaningful way a part of it. The friendship and influence of the older Jeremy Bentham from 1808 onwards slowly but surely transformed Mill into an English utilitarian. And of course in his later life Mill was looked upon by others as one of the high priests of Benthamite utilitarianism. In social outlook, Mill certainly believed in natural liberty but failed to appreciate the dangers to it implicit in utilitarianism as an intolerant and coercive creed of 'social justice'. In political economy, Mill favoured a strictly deductive analytical approach that was very different from the historically aware and more empirically based theories, developed over the eighteenth century, typical of the mainstream Scottish tradition in this field.

James Mill is what he chose to become: not a thinker within the Scottish intellectual tradition but a central figure in the early period of English utilitarianism. De gustibus non est disputandum.

\section{Notes}

In the biographical part of this chapter I have drawn extensively on the following sources: Bower (1990: 8-23), Burston (1973: 36-62), Cavenagh (1931: 74-131), Mazlish (1975: 4-7, 48-76) and Winch (1966: 1-22).

1 In this chapter all page references to James Mill's Elements of Political Economy are to the third edition of 1826. I'm grateful to the Internet bookshop Amazon.co.uk for having discovered a copy of this book that was available at the present time for private purchase. Amazon put me in touch with Mr Alex Fotheringham, a bookseller in Hexham, Northumberland. Interestingly, the copy of Mill that Mr Fotheringham was offering for sale was at one time part of the library of the Edinburgh Society of Accountants. I found the book to be largely uncut, showing that it had never been completely opened. It gave me a strange feeling to think that I, in the year 2004, was the first person to have read this particular copy from cover to cover since it left the workshop of the London printer C. Baldwin, of New Bridge Street, 178 years ago. 


\section{References}

Bower, George ([1881] 1990) Hartley and James Mill, Bristol: Thoemmes.

Burston, W. H. (1973) James Mill on Philosophy and Education, London: Athlone Press.

Cavenagh, F. A. (1931) James and John Stuart Mill on Education, Cambridge: Cambridge University Press.

Hayek, Friedrich A. (1967) Studies in Philosophy, Politics and Economics, London: Routledge.

Hume, David ([1752] 1987) 'Of Money', in Eugene F. Miller (ed.), David Hume: Essays, Moral, Political and Literary, Indianapolis IN: Liberty Classics, pp. 281-94.

Locke, John ([1690] 1977) An Essay Concerning Human Understanding, edited with an introduction by A. D. Woozley, Glasgow: Collins.

Malthus, Thomas Robert ([1798] 1966) An Essay on the Principles of Population, London: Macmillan.

— ([1820] 1989) Principles of Political Economy I, variorum edition edited by John Pullen, Cambridge: Cambridge University Press.

Mazlish, Bruce (1975) James and John Stuart Mill, London: Hutchinson.

Mill, James ([1820] 1955) Essay on Government, edited with an introduction by Currin V. Shields, Indianapolis IN: Library of Liberal Arts/Bobbs-Merrill.

— (1826) Elements of Political Economy, 3rd edn, London: Baldwin Cradock \& Joy.

Mill, John Stuart ([1843] 1965) A System of Logic, London: Longmans.

— ([1859] 1991) 'On Liberty', in On Liberty and Other Essays, edited by J. Gray, Oxford: Oxford University Press.

— ([1863] 1998) Utilitarianism, edited by R. Crisp, Oxford: Oxford University Press.

— ([1873] 1989) Autobiography, edited with an introduction by John M. Robson, London: Penguin Books.

Popper, Karl R. ([1957] 1960) The Poverty of Historicism, 2nd edn, London: Routledge.

- (1963) Conjectures and Refutations, London: Routledge.

Reid, Thomas ([1785] 1969) Essays on the Intellectual Powers of Man, edited with an introduction by Baruch A. Brody, Cambridge MA: MIT Press.

Smith, Adam ([1776] 1981) An Inquiry into the Nature and Causes of the Wealth of Nations I, Indianapolis IN: Liberty Fund.

Winch, Donald (ed.) (1966) James Mill: Selected Economic Writings, Edinburgh: Oliver \& Boyd. 


\title{
9 John Ramsay McCulloch
}

\author{
D. P. O'Brien
}

Leszek Kolakowski started his great book on Marx with a statement of what should be, but apparently is not, blindingly obvious - Karl Marx was a German philosopher (1978: 1). We begin with a correspondingly obvious but equally neglected truth; John Ramsay McCulloch was a Scottish economist. The neglect of this truth seems to spring from an Anglocentric approach to the history of economics, dating at least from Alfred Marshall and extending through most of last century, an approach which all too easily became Ricardocentric. As will, however, become clear from the following account, Ricardo's influence upon McCulloch was one of many during a long professional life; it was, though for a time deep, transient; and to understand McCulloch's position as a whole it is necessary to look at the very wide range of influences upon him.

\section{Biography}

McCulloch was born on 1 March 1789 at Whithorn in Galloway. ${ }^{1}$ His childhood was unhappy, due mainly to the behaviour of his maternal grandfather. However, he appears to have had a remarkable grounding in the classics from an Irishman employed as a labourer by his grandfather. In October 1807 he went to Edinburgh University, where he studied mathematics, agriculture and ethics. From the first two courses he seems to have derived considerable benefit; in particular he seems to have been exposed to the mathematical texts of Robert Hamilton, on which he was to draw and which left him with a strong appreciation of actuarial concepts. The ethics course, to judge from comments which McCulloch wrote late in life, was a disaster (1862: 44). He left without graduating in 1811. He married early, in August that year, and was to father no fewer than ten surviving children.

While apparently working as a lawyer's clerk, he seems to have engaged upon a strenuous exercise in self-education in economics. This bore early fruit in two essays on the national debt $(1816 \mathrm{a}, \mathrm{b})$. In these the influence of Malthus is apparent (O'Brien 1995b). The history and literature of economics were to remain lifelong passions (O'Brien 1995a), and he 
produced a guide to the literature of the subject (McCulloch 1845a), two editions (McCulloch 1856, 1862) of the catalogue of the remarkable library which he built up, and a number of volumes of rare economics publications (McCulloch 1856-59).

In the second half of 1817 he became editor of the newly founded Scotsman newspaper. He remained editor up to 1821 . This was a vital formative period in his development, as many of his ideas were tried out on the Edinburgh public in the form of front-page essays on economics. However, the Scotsman was founded as a Whig newspaper in opposition to the ruling Edinburgh Tory establishment. McCulloch's editorship thus involved him in the heat of Edinburgh factionalism, including violent personal attacks upon him, and legal actions against the paper.

It was during this period that McCulloch began to contribute to the Edinburgh Review. It was his first article (1818), an enthusiastic if not wholly comprehending account of Ricardo's Principles, which paved the way for the association in later minds of McCulloch with Ricardo. Ricardo had, unlike Malthus (who inadvertently ignored it. James 1979: 311), responded politely to McCulloch's first essay on the national debt; and over the years to 1823, particularly following the Edinburgh Review, McCulloch became quite close to Ricardo intellectually, although without grasping wholeheartedly the fundamental nature of the Ricardian model, let alone the role within it of the Invariable Measure of Value.

McCulloch enjoyed a good relationship with Francis Jeffrey, the editor of the Review, though apparently unaware that Jeffrey's own attitude towards him was ambiguous, and he seems to have become a close friend of Jeffrey's successor MacVey Napier. For the next twenty years he contributed seventy-eight (or possibly seventy-six - there is a dispute about two: O'Brien and Darnell 1982: ch. 7) articles to the Review and there is no doubt that, despite the ostensible anonymity of the contributions, they helped substantially to establish McCulloch's reputation.

McCulloch also began to teach economics at an early stage. He started private classes in Edinburgh in 1820 and moved on to delivering lectures, beginning in 1822. It was thus natural that he should be chosen as the person to deliver the Ricardo Memorial Lectures in London, after Ricardo's death, both because of his association with Ricardo and because of his experience in delivering lectures. These lectures seem to have been a considerable success, and they further helped to establish McCulloch's reputation.

But, more important, from 1816 onwards the stream of publications never dried up. Up to 1832 the majority of his published output concentrated on general principles, but as a member of the Scottish school McCulloch was deeply concerned with the statistical counterparts of economic concepts, as became apparent from an early stage in his Edinburgh Review articles. In time he became one of the most remarkable compilers of economic data, publishing in 1832 the first edition of his great Commer- 
cial Dictionary. He seems to have had little scruple in using his contacts to obtain, at public expense, data he required. Ricardo, to whom he turned, seems to have been reluctant at first to use his parliamentary position to request official data but ultimately obtained useful information for McCulloch, and other MPs with whom he was acquainted were successfully asked for assistance with data requests (O'Brien 1970: ch. 5).

Hand in hand with the literary efforts were McCulloch's efforts to build upon his successes as a teacher and to become an academic. These concentrated upon possible positions in Edinburgh; but his plans were betrayed by Jeffrey to the Tory opposition, and in any case it seems unlikely that McCulloch, associated as he was with the Scotsman, would ever have satisfied the Edinburgh establishment of his credentials. But then, with the help of James Mill, and also of Henry Brougham (later to become McCulloch's pet hate), he was appointed to the newly created Chair of Political Economy at the new University of London. He held this position from 1828 until 1837, although he seems to have given no lectures after 1835, and it was not financially of great benefit to him after the first three years, during which he enjoyed a guaranteed income from the university (ibid.: ch. 4).

He thus perforce relied on his pen to support his numerous family. However, in 1838 his fortunes underwent a dramatic improvement. Lord Melbourne appointed him Comptroller of the Stationery Office, a job which he undertook with all his remarkable energy and force of character. There is no doubt that he was a successful civil servant and that his administration of the office was notable for the control over public expenditure which he achieved.

But the publications continued. There seems to have been some understanding that if he accepted the civil service position he would cease his journalism, including his contributions to the Edinburgh Review. But during his time as a civil servant he produced three editions of a substantial work on taxation (O'Brien 1975b), albeit incorporating earlier material, and new editions of his Principles of Political Economy first published in 1825, of his Commercial Dictionary, and of a Geographical Dictionary which had been first published in 1841. McCulloch died in London in 1864.

\section{Economic writings}

The first thing to appreciate about McCulloch's economic writings is that his output was extremely large - quite exceptionally so by nineteenthcentury standards. It is not possible to obtain an accurate picture of his position by looking at single publications in isolation. Second, McCulloch's basic approach was solidly grounded in the Wealth of Nations indeed, he referred to Smith as his 'great economical chief' (1862: vi). Third, McCulloch attempted to incorporate into this Smithian framework a number of Ricardian effects, apparently believing that these merely 
complemented Smith. Finally, he successively discarded the Ricardian elements as he became aware that they conflicted with the available data. To illustrate these points, we begin by looking at his treatment of capital accumulation and growth.

\section{Capital and growth}

Like Smith, McCulloch's writings focus upon the process of economic growth, brought about by the accumulation of capital and the division of labour (O'Brien 1970: ch. 12). Capital, accumulated from profits which provided both the motive and the means for accumulation, raised the productivity of labour. In all this McCulloch afforded a key role to inventions. Like Smith, McCulloch stressed the institutional requirements of growth, above all security of property. This was associated with good government and equal treatment of individuals, including religious tolerance. Important to growth were natural resources, internal and external freedom of trade, good communications, a banking system and education McCulloch attached particular importance to the concept of human capital.

McCulloch began his career as an economist forty years after the publication of the Wealth of Nations, and he continued writing for almost half a century. In the circumstances it is not surprising that his vision of the structure of the economy should differ from that of Smith. He rejected Smith's view that agriculture was the key sector (though, like Smith, he paid attention to the correct institutional framework for that sector) and stressed the importance of the manufacturing sector. He appreciated its role as an engine of growth, though showing concern both about possible over-development of manufacturing, given the sectoral interdependence of the economy, and about the distributional effects of the factory system. But his outlook was basically Smithian, though bearing the scars of the industrial revolution. Like Smith he recognised a significant role for government, and rejected the use of laissez-faire as a slogan. Not only had government to be responsible for communications and infrastructure, but it had a significant regulatory role to play in relation to such issues as food purity, shipping, child labour, employer liability and public utilities.

All this was essentially a pragmatic extension of Smith's treatment. McCulloch seems to have been more inclined than Smith, however, to afford a productive role to those employed in the public sector (of whom he became one); though he accepted Smith's distinction between productive and unproductive labour, he broadened the former category so far, to include anything which could lead to further output, that the distinction ceased to have much weight.

Thus far we have seen how Smithian McCulloch was both in spirit and, frequently, in detail. However, a number of Ricardian elements were incorporated uneasily into this Smithian framework. These included an 
inverse relationship between wages and profits. This was, however, stated usually in proportional terms, since McCulloch did not employ the invariable measure of value, and he failed to spot that, as Cannan later pointed out, Ricardo's numerical model involved fixed capital/labour ratios, a concept which was entirely foreign to McCulloch's general treatment of economic growth. The inverse relationship of wages and profits led McCulloch to accept the Ricardian argument that the Corn Laws would raise wages and depress profits. He also seems to have been impressed with the idea that agricultural profit determined profit elsewhere in the economy. Again this was a foreign body in the general treatment of growth by McCulloch, because elsewhere he stressed the effect of inventions in raising manufacturing profits. He also accepted Ricardo's version of the stagnation thesis, with rising wages depressing profits, as the price of corn rose with the extension of cultivation, and rejected Smith's concept of the exhaustion of investment opportunities.

But it is important to recognise that McCulloch ultimately rejected all the Ricardian elements. First, he came to accept that profits had fallen in Holland, as was widely accepted to have occurred, owing to capital accumulation. This was a Smithian interpretation of the data. Second, he came, on the basis of the statistical evidence he gathered, to the view that the Corn Laws did not have a significant effect on the price of wage goods. Accordingly, the Ricardian stagnation thesis was questionable. He also came gradually to the conclusion that agricultural improvements could continuously countervail the effects of population pressure on the margins of fertility, and thus remove the inevitability of a rising cost of wage goods. He also rejected the Malthusian population mechanism, so it did not follow that there was an inevitability about progress to the margin of cultivation. He recognised the importance of non-agricultural wage goods, which also helped to keep down the cost of subsistence, and finally rejected even the inverse movement of wages and profits on the grounds that a wage rise was likely to stimulate entrepreneurial innovation to maintain profits. Finally, he had never accepted Ricardo's arguments concerning the harmful effects of machinery. He grasped the basic point that machinery was not installed to diminish total product, as Ricardo's numerical example (derived from Barton) assumed.

\section{Value and distribution}

One reason for the linking of McCulloch's name with that of Ricardo is that McCulloch expounded, for popular purposes, a labour theory of value - a labour theory of cost of production, which he understood to have been Ricardo's theory and in endorsement of which he cited Ricardo's name. Parallel with this, however, in the more sophisticated parts of his writings, he returned to Smith's cost of production approach, though with labour predominant (O’Brien 1970: ch. 8). 
However, in all this there was one fundamental difference from Ricardo. For, from the very outset, McCulloch rejected the concept of an invariable measure of value. Indeed, it is doubtful that he appreciated the central importance of this concept to Ricardo; and he informed the latter that his dispute with Malthus about such a measure was futile.

Value for McCulloch thus meant simply exchange value. As a starting point, the costs incurred were wages plus depreciation - the wages of indirect labour. Even at this stage, however, a number of issues arise. First, as Ricardo had accepted in 1817, relative values could be altered by a rise in wages, which, in his model, reduced profits. From his first writings on value in 1817 McCulloch accepted this. Second there was the problem exemplified by the increase in the value of wine being stored to mature. Ricardo explained this by the interest charge on the capital locked up in the wine stocks, not surprisingly, given his business background. McCulloch, however, was later to incur some ridicule by claiming that the labour embodied in the stored wine went on working during the maturing process (Ricardo 1951-55: vol. 8, 137-9; vol. 9, 369). What he was getting at was that some kind of productivity was necessary for an increase in value. The third issue is the role of demand. McCulloch does seem to have recognised that the cost which determined value was that at the margin of production, and that demand located the margin. None the less all the emphasis was on the cost side. Rent was eliminated from cost, following the standard Ricardian error (the neglect of transfer earnings), and so the only costs were labour and capital.

At one stage in his early writings McCulloch attempted to treat cost as 'real' cost, i.e. disutility. This may have been to justify the labour approach to value, though of course labour (measured by wage payments) is only loosely related to disutility.

In the second (1830) edition of his Principles, McCulloch made a significant change to the treatment of the role of capital. Jettisoning the 'labour goes on working' argument, he adopted Ricardo's claim that interest on the capital invested in the wine stocks was the explanation for the value increase as wine was stored to maturity (1825/30: 352-4). But this was not an adequate explanation; wine stored beyond maturity did not increase in price, though capital was still locked up in it. For the services of capital to command a price, it needs not only to be limited in supply but also to increase the output of co-operating factors. McCulloch's change essentially involved adopting Ricardo's confusion between necessary and sufficient conditions for the existence of a premium over and above the costs of labour and depreciation. It was not until the 1838 edition of McCulloch's version of the Wealth of Nations that he recognised both waiting and productivity as necessary for added value, and he concealed this in a short note on labour while leaving the reader with his popular theory of value for the most part (1828/38: 436).

The rate of interest on capital depended on the going rate of profit, as 
Hume had argued (O'Brien 1970: 309-12). This was determined by the intersection of the (marginal) productivity of investment with the (marginal) supply price of saving. McCulloch argued that saving was a function of the profit rate. The marginal productivity of investment was explained in terms of the physical productivity of capital, neglecting the point that physical product has to be translated into value product. McCulloch followed Tooke (1826) closely in deducting, from gross profit, the wages of management and compensation for non-insurable risk. He also deducted rent on market position, in order to arrive at the competitive rate of net profit. The competitive rate had a key role in the allocation of capital, and so McCulloch was opposed to the usury laws, of which Smith had approved, as interfering with the operation of the capital market.

Since relative quantities of labour could only mean relative quantities of wages, wage theory was important for value theory. Demand for labour was approached via a wage fund, treating capital as demand for labour following Smith. As in his popular value theory, McCulloch was inclined to paint on a broad canvas here and to write about total capital and total population as determining the general level of wages in the economy, allowing him to stress the importance of the relative rates of increase of the two magnitudes. But a more precise formulation, relating wage capital in the form of a 'wage fund' to working population, runs into the difficulty which Wicksell was later to point out; the wage rate depends upon the division of a given amount of capital between fixed and circulating capital, but the capital-intensity of production - that division - depends upon the wage rate. There was also the problem of unproductive labour, the demand for which could not be explained by a wage fund. McCulloch seems to have sidestepped this problem, and to have been able to make little headway with another difficulty - the relation between the demand for commodities and the demand for labour (O'Brien 1970: ch. 14).

In analysing the supply of labour, McCulloch produced rather better work. He distinguished four labour supply functions. First there was the secular (population) function, with a rising level of psychological subsistence rather than a constant at physical subsistence. Secondly there was a rising supply schedule where labour responded to higher wages with an increased supply of labour in order to take advantage of the possibility of a higher standard of living. There were also two negatively sloped labour supply functions; one where a rise in wages meant that it was no longer necessary to work exhaustingly to survive at all, and one where extra family members were added to the labour force when real wages fell with a rising price of food.

In all this, McCulloch's rejection of the basic Malthusian mechanism, from the late 1820s, is important. Although the situation in Ireland was different, and wages were kept at physical subsistence by fertility (and mortality when wages fell below subsistence), the crucial mechanism in England which prevented wages falling to physical subsistence through 
intemperate procreation was moral restraint. This, combined with the lag between procreation and active additions to the labour force, enabled wage rises to be incorporated into a rising level of conventional subsistence.

McCulloch followed Smith in emphasising the advantage of high wages - wage earners were the majority of the population, and thus their welfare was that of the majority of society. In addition, high wages were conducive to social stability and the security of property which was so vital for economic growth. This growth itself led in turn to capital accumulation and to further increases in wages.

McCulloch's analysis of the general level of wages was complemented by an analysis of supply to different occupations - the equalisation of net advantage - following Smith, who had, in turn, followed Cantillon. McCulloch also paid attention to the operation of labour markets; in particular he attacked the Combination Laws, which restricted the activities of trade unions. The laws were futile (because of the power of market forces), unjust (because of the inequality of bargaining power between employer and employee) and dangerous, in threatening the stability of society and security of property. The labour market should be allowed to function freely, though child labour should be the subject of regulation, as should any attempts to pay wages in kind (the truck system).

\section{Money and trade}

\section{Money}

McCulloch's monetary theory started from the Hume-Smith-Thornton theory of the distribution of the precious metals (O'Brien 1970: ch. 9). McCulloch accepted the Ricardian definition of excess (that the currency was by definition in excess if the exchanges were depressed to the gold export point). However, his treatment of this was informed both by William Blake's distinction between the real and the nominal exchange (the latter reflecting currency depreciation) and by Thornton, both in recognising that velocity of circulation varied with confidence, so that a given supply of currency might be in excess at one time and not at another. He recognised also that there was no instantaneous adjustment to long-run equilibrium of the kind which Ricardo tended to assume. Thornton's influence shows also in McCulloch's recognition that sudden changes in the money supply could produce changes in aggregate demand and financial crises. In particular McCulloch stressed the vulnerability of the country bank notes to changes in confidence when increased demand for liquidity arose. A reduction in the money supply, and subsequent deflation, involved losses on stocks, an increase in the debt burden and in the weight of fixed charges, and a shock to economic activity. McCulloch paid particular attention to the country bank failures in 1814-16 (and he perceived 
their importance more clearly than did his contemporaries). The failures certainly reduced the note issue so far as to bring the paper currency close to gold parity well before the resumption of specie payments in 1819. This had produced severe economic depression.

Broadly speaking, McCulloch was a moderate bullionist. He followed Thornton and the Bullion Report in rejecting the Real Bills doctrine, and accepted that there was no limit to over-issue of notes (and to the resulting unstable speculation) if the lending rate of interest was kept below the marginal rate of profit. While McCulloch actually favoured mild inflation, based upon increasing precious metal supplies, as reducing the value of fixed charges, he did not favour paper money inflation. But metallic inflation could be beneficial - unlike Ricardo, McCulloch was impressed by Hume's exposition of the stimulatory effects.

As a moderate bullionist, McCulloch believed that the linking of the currency to precious metal was vital for economic stability, though this did not necessarily imply a commitment to full convertibility. In the 1820 s he argued for a limited bullion standard, one different from that envisaged by Ricardo, with paper currency kept above the value of gold through limiting convertibility. Failing the introduction of such a scheme, he argued, the Bank of England should follow the principle of 'metallic fluctuation', so that a mixed currency of paper and metal fluctuated in amount exactly as if it were entirely metallic. McCulloch stands as one of the formulators of this idea in the mid-1820s, though Joplin has the real priority (O'Brien 1975a, 1993).

But the role of the Bank itself was important. Unlike Ricardo, who was hostile to it, McCulloch regarded the Bank as of vital importance as the fulcrum of the monetary system, which it had to control via its lending rate (Bank rate). Indeed, he advocated the suppression of the country bank notes, and giving the Bank a monopoly on note issue. Like Smith, he was opposed to laissez-faire in banking. Moreover, unlike his friends Overstone and Torrens in the currency school, he was happy to leave the Bank some discretion - specifically the discretion to distinguish between 'internal and external drains' (loss of specie domestically or over the exchanges), as Thornton had argued. Nevertheless he ultimately came to accept the 1844 Bank Charter Act with its replacement of the discretion previously enjoyed by the Bank with rules.

\section{Trade}

An open economy on a metal standard is the starting point for McCulloch's writings on trade, which are based firmly on Smithian foundations (O'Brien 1970: ch. 10). For McCulloch, absolute advantage, rather than the comparative advantage theory associated with the name of Ricardo, was the basis of trade. Indeed, he publicly rejected Ricardo's chapter on trade. His position was based upon a parallel between international and 
interregional trade that Ricardo rejected, with a significant degree of international factor mobility.

Trade, viewed as international specialisation, widened the market and made possible greater division of labour; it provided a dynamic stimulus to industry, and increased income per head over time. Thus freedom of trade was highly desirable. Protection distorted the allocation of resources.

McCulloch argued for unilateral freedom of trade. He had little faith in commercial treaties, and attacked in particular the Cobden-Chevalier treaty of 1860, as well as the earlier Methuen treaty with Portugal, of which Smith had been critical (O'Brien 1976, 1977). Unilateral removal of duties did not leave home production completely unprotected, because transport costs provided a significant degree of protection. But artificially increasing this through tariffs in turn increased fluctuations in the domestic economy, through the over-expansion of protected industries, and led to smuggling and corruption. It offered no advantages in the form of increased employment and economic growth, because it narrowed the extent of the market on which they depended.

But McCulloch was not a dogmatic free-trader, despite his later image. In particular, opposed as he was to direct taxation, and favouring commodity taxation, he was prepared to see import duties of even 25 per cent, where they were balanced by corresponding duties on domestic sources of supply. There was a need for balance; Peel's reform of duties in 1842 had gone far enough, but Gladstone's wholesale abandonment of many tariffs as a source of revenue had gone much too far.

Specie flows would ensure that the balance of payments balanced so that there need be no worries on that score in adopting unilateral removal of duties. McCulloch's arguments in support of the idea of an automatic balance were not the best part of his work, and the specie-flow argument, and a demand transfer argument, are the only plausible ones among a series of mechanisms for automatic balance which he advanced. Both these arguments also feature in McCulloch's analysis of the transfer problem in international trade - McCulloch was famous (even notorious) in his lifetime for advancing demand transfer as the underlying mechanism for rent remittances to Irish absentee landlords.

\section{Public finance and policy}

The remainder of McCulloch's interests can be sketched only briefly. He wrote extensively on public finance, from his two 1816 essays on the national debt (1816a, b) and his years with the Scotsman (O'Brien 1970: ch. 11, 1975b). Unlike Ricardo, who ignored even Pitt's controversial income tax, McCulloch was concerned with issues in the real tax system. He took an ability-to-pay approach, concentrating on the revenue side of the account, and sought to find ways of tailoring the tax system to min- 
imise damage to economic growth. These included intersectoral balance of tax burdens, and the maintenance of individual taxes at a sufficiently low level that they stimulated effort to overcome them, rather than delivering a shock to enterprise.

His preference was for a broadly based system of indirect taxes at moderate levels. It was undesirable to tax basic foodstuffs, because that could depress the psychological subsistence level - McCulloch rejected the simple Ricardian idea that such a tax would be passed on in the form of higher wages. He was, for the most part, not in favour of direct taxes. In particular he was opposed to the income tax. He believed that it should be levied on an imputed return on the present value of the prospective stream of income receipts, an approach which enjoyed some popularity in the mid-nineteenth century (O'Brien 1999: vol. 6), when the very existence of the income tax was still highly controversial. The operational difficulties of such an approach were so severe, he argued, particularly in relation to life expectancy data (necessary for calculating present values), and the arbitrary nature of the interest rate used, that he felt that such a tax could not be operated fairly. There was a host of other difficulties as well, notably whether temporary income should be taxed at a lower rate to allow for saving, and allowance for depreciation of investment in human capital. Finally, there was the overwhelming problem of evasion. But if an income tax were to be imposed, it had to be proportional - as McCulloch presciently observed, once that rule was abandoned we were at sea without rudder or compass.

He recognised that indirect taxes had a number of disadvantages - the distortion of consumer choice, and thence of the allocation of capital, regression, and the inducements to smuggling. But at moderate levels, and with a broad base, he felt these disadvantages were sufficiently small to make such taxes preferable to an income or indeed a property tax. But the low level was important; not only did it minimize the harm, but it maximised the revenue.

It was important that in peacetime government should raise sufficient revenue to cover its expenditure. Borrowing was permissible only in financial emergencies such as 1688 and Peel's reform of the import duties in 1842. War finance, however, he eventually decided, after initially being swayed by Ricardo's argument to the contrary, should be debt-financed. If taxes were used instead, it would place taxpayers themselves in the position of borrowers (at worse borrowing rates than government) and the commodity taxes would have to be pushed to levels which would pass from stimulation to shock. But borrowing should be at par, to avoid an extra charge for redemption as low-coupon debt, issued below par, rose to par after a war.

It was, however, a second-best solution, for the debt created was a burden. Its creation consumed capital, while the cost of paying interest brought about a creeping increase in taxation which could cause capital 
flight. The debt burden should be reduced. Initially he argued that this should be done by reducing the interest paid. But he was then convinced by Robert Mushet's calculations that the debt holders had already been robbed through the payment of interest in depreciated currency. Like Ricardo, he later advocated a capital levy to pay off the debt, though McCulloch was clear that the idea was Archibald Hutcheson's long before Ricardo. He regarded a sinking fund as futile, and followed Robert Hamilton in pouring scorn on Richard Price's confusion between economics and the mathematics of compound interest, which led the latter to believe that the debt could easily be repaid (ibid.: vols. 1, 3). Ultimately the only solution to debt was budget surpluses.

Though McCulloch's approach to public finance was in ability-to-pay terms, rather than considering both sides of the account, revenue and expenditure, he did consider a number of areas of government activity and policy. His views on the role of government in economic growth have already been noted, but he also paid attention to pauperism and the Poor Law, emigration, education, regulation of the hours of labour, and the Corn Laws.

Ricardo essentially accepted the population mechanism in the first edition of Malthus's Essay, as he needed it for his model - wages could be treated as a constant, being at subsistence. McCulloch, however, was at first a Malthusian of the second edition of the Essay, emphasising the importance of moral restraint in restricting population growth, and psychological rather than physical subsistence. This in turn led him to hold, at least up to 1826, a hostile view of the Poor Law as undermining moral restraint and depressing psychological subsistence (O'Brien 1970: 314-19). None the less, even at this stage, McCulloch conceded that poor relief might be necessary in an economy like that of Britain where demand for labour fluctuated (ibid.: 319-24).

After 1826 McCulloch changed his mind radically. This was partly because he had come to believe that if landlords restricted cottage building it would be sufficient to limit population growth and also, as the agitation over the Reform Bill heightened, because he feared social disorder. All that was required, he held, was a return to the form of the Poor Law which has been in operation until 1782 before it was weakened by Gilbert's Act and the Speenhamland system. This would certainly be preferable to Senior's New Poor Law of 1834 with its workhouse test, which McCulloch strongly opposed (ibid.: 324-31).

Poor relief could be coupled with expenditure of public money on assisted emigration - McCulloch was a supporter of Wilmot Horton. Colonies provided a valuable outlet for a growing population, but should not be kept under the control of the mother country - McCulloch followed Smith in this and in deploring monopolisation of the colonial trade, which was either useless or distorting (if it were to alter the pattern of trade). In arguing for freedom of the colonies he was trenchant in his 
condemnation of the East India Company and saw no value in the Indian empire. Colonies should be allowed to develop naturally; in particular they should not be subject to an artificial degree of concentration of population. McCulloch opposed Wakefield's schemes, which, he believed, mimicked the disadvantages of an old country affected by a shortage of land, and held that the self-interests, of the colonists would produce the right degree of concentration (ibid.: 331-44).

For the population remaining at home, education should be provided along the lines of the Scottish parochial schools. The state had a vital role to play here - McCulloch was contemptuous of laissez-faire arguments applied to education - though the education should not be free. Education would both help to raise living standards and to produce social stability (ibid.: 344-7).

Finally there is the question of agricultural protection. McCulloch was an influential critic of the Corn Laws, but not on straightforward Ricardian stagnationist lines (ibid.: 378-95). Rather he argued that the main damage came from reduced elasticity of foreign supply, as the British market was open only intermittently, leading to price fluctuations which harmed domestic agricultural production. In this context McCulloch developed the idea of what we would now call a 'cobweb'. Such price fluctuations not only damaged agriculture, but caused hardship to wage earners, and endangered social stability. He buttressed all this with the standard Ricardian argument that the Corn Laws depressed profits, but this was subsidiary to his other concerns, and as McCulloch gathered increased statistical information about the likely level of corn prices in the event of free importation he seems to have regarded the Ricardian argument as less and less important, even though he endorsed Ricardo's scheme for a low fixed duty to provide some agricultural protection.

\section{Conclusion}

Even within this brief sketch, it should be apparent that McCulloch's writings fall squarely within the Scottish tradition of enquiry. That there were Ricardian elements incorporated into a much wider canvas is clear enough; but these elements diminished in importance over time, while there were significant parts of Ricardo's theoretical schema which McCulloch rejected from the outset, such as an invariable measure of value and the theory of comparative cost. McCulloch was not a model builder like Ricardo or indeed Torrens. Rather, like his avowed leader Smith, he wove together a complex picture of a growing economy, paying careful attention to a wide range of institutional and quantitative considerations. 


\section{Notes}

I am grateful to Dr Julia Stapleton and Professor John Creedy for comments on an earlier version of this chapter.

1 The biographical details are drawn from O'Brien (1970: chs 3-6).

\section{References}

James, P. (1979) Population Malthus: His Life and Times, London: Routledge.

Kolakowski, L. (1978) Main Currents of Marxism I, The Founders, translated by P. S. Falla, Oxford: Oxford University Press.

McCulloch, J. R. (1816a) An Essay on a Reduction of the Interest of the National Debt, proving that this is the only possible Means of relieving the Distresses of the Commercial and Agricultural Interests: and establishing the Justice of that Measure on the surest Principles of Political Economy, London: Mawman; Edinburgh: Brown.

- (1816b) Essay on the Question of reducing the Interest of the National Debt; in which the Justice and Expediency of that Measure are fully Established.

— (1818) 'Ricardo's Political Economy', Edinburgh Review 6 (June): 59-87.

- (1825) The Principles of Political Economy', with a Sketch of the Rise and Progress of the Science, Edinburgh: Tait; 2nd edn Edinburgh and London: Tait, 1830; 3rd edn Edinburgh: Tait, 1843; 4th edn Edinburgh: Black and London: Longman, 1849; 5th edn Edinburgh: Black, 1864. The 1849 edition is reprinted with introduction by D. P. O'Brien in The Collected Works of J. R. McCulloch II, London: Routledge/Thoemmes, 1995.

- (ed.) (1828), A. Smith, An Inquiry into the Nature and Causes of the Wealth of Nations, Edinburgh: Black and Tait; 2nd edn Edinburgh: Black and Tait, 1838; 3rd edn Edinburgh: Black, 1863.

- (1832) A Dictionary, Practical, Theoretical, and Historical, of Commerce and Commercial Navigation, London: Longman. Subsequent editions were published in 1834-39, 1840, 1844, 1846, 1847, 1852, 1854, 1856 and 1859, with Supplement 1860. Longman remained the publisher.

- (1841-42) A Dictionary, Geographical, Statistical, and Historical, of the Various Countries, Places, and Principal Natural Objects in the World, London: Longman; 2nd edn 1845-46, 3rd edn 1849, 4th edn 1852, 5th edn 1854, all published by Longman.

- (1845a) The Literature of Political Economy: a Classified Catalogue of Select Publications in the Different Departments of that Science, with Historical, Critical, and Biographical Notices, London: Longman.

- ([1845b] 1995) A Treatise on the Principles and Practical Influence of Taxation and the Funding System, London: Longman; 2nd edn London: Longman, 1852; 3rd edition, Edinburgh: Black, 1863. The 1845 edition is reprinted as vol. IV of The Collected Works of J. R. McCulloch, Introduction by D. P. O'Brien, London: Routledge/Thoemmes.

— (1856) A Catalogue of Books, the Property of the Author of the Commercial Dictionary, London: printed by Spottiswoode.

- (ed.) (1856-59) Classical Writings on Economics, 6 vols, covering Commerce (two), Money, Paper Currency and Banking, the National Debt and the Sinking Fund, and miscellaneous subjects. Reprinted London: Pickering \& Chatto, 1995. - (1862) A Catalogue of Books, the Property of a Political Economist, privately 
printed, reprinted in The Collected Works of J. R. McCulloch, Introduction by D. P. O'Brien, London: Routledge/Thoemmes, 1995, vol. VI.

O'Brien, D. P. (1970) J. R. McCulloch: A Study in Classical Economics, London: Allen \& Unwin, reprinted London: Routledge, 1992, 2003.

- (1975a) The Classical Economists, Oxford: Clarendon Press.

(ed.) (1975b) J. R. McCulloch: A Treatise on the Principles and Practical Influence of Taxation and the Funding System, Edinburgh: Scottish Academic Press.

- (1976) 'Customs Unions: Trade Creation and Trade Diversion in Historical Perspective', History of Political Economy 8, 4: 540-63. Reprinted in Methodology, Money and the Firm II, pp. 71-94, Aldershot: Edward Elgar.

- (1977) 'Torrens, McCulloch and Disraeli', Scottish Journal of Political Economy 24 (February): 1-18. Reprinted in Methodology, Money and the Firm II, pp. 53-70, Aldershot: Edward Elgar.

(1993) Thomas Joplin and Classical Macroeconomics, Aldershot: Edward Elgar.

(1995a) 'McCulloch and the Literature of Economics', in J. R. McCulloch:

Classical Writings on Economics I, pp. vii-xxxviii London: Pickering \& Chatto.

- (1995b) Introduction to J. R. McCulloch, Essay on the Question of Reducing the Interest of the National Debt in The Collected Works of J. R. McCulloch I, London: Routledge/Thoemmes.

— (ed.) (1999) The History of Taxation, 8 vols, London: Pickering \& Chatto.

— and Darnell, A. C. (1982) Authorship Puzzles in the History of Economics, London: Macmillan.

Ricardo, D. (1951-55) The Works and Correspondence of David Ricardo edited by P. Sraffa with M. H. Dobb, Cambridge: Cambridge University Press.

Tooke, T. (1826) Considerations on the State of the Currency, London. 


\title{
10 The place of Thomas Chalmers in Scottish political economy
}

\author{
A. M. C. Waterman
}

Thomas Chalmers was born in Anstruther, Fife, in 1780, the sixth of fourteen children. He was educated at the parochial school until the age of twelve, when he enrolled at the University of St Andrews. In 1795 he became a divinity student, graduated in 1798, was licensed to preach the gospel in 1799, and in 1802 ordained in the Church of Scotland. He served in the parish ministry, first at Kilmany, then in Glasgow until 1823. In that year he became Professor of Moral Philosophy at his alma mater. Thereafter he occupied Chairs in divinity, first at the University of Edinburgh, then at New College until his death in Edinburgh in 1847.

If the study of economics can be an addiction, then the Reverend Thomas Chalmers was a life long addict. He borrowed Wealth of Nations from St Andrews University library on 13 August 1792 at the age of twelve and a half. During the last three years of his life, being then in his seventh decade, 'the most important Scottish man of his time' (Carlyle) and passionately involved in ecclesiastical and political activity, he contributed no fewer than seven articles on political economy to the North British Review (Watt 1943: 73-4). 'Let my adoption of Political Economy,' he prayed in 1825 , 'set me to the vigilance of one who is fearful and resolved in the strength of Thy grace against all secular contamination' (Hanna 1849-52: III, 93). But two years later his 'chief earthly ambition' was 'to finish a treatise on Political Economy' (ibid.: III, 298).

It has been suggested that Chalmers's devotion to political economy 'was secondary to, and grew out of, his lifelong crusade to correct the problem of poverty in industrial cities' (Hilton 1988: 64). But as early as 1800-01 he had attended Dugald Stewart's famous Edinburgh lectures, which inaugurated the conversion of the British ruling classes to the importance of political economy in general and of Adam Smith in particular (Fontana 1985: 4-5). A testimonial of 1801 noted that 'he is at present with genius and ability investigating some of the difficult and interesting subjects of Philosophy and Political Economy' (Hanna 1849-52, I: 490). Chalmers was ordained in the Church of Scotland and became minister of Kilmany, Fife, in 1803. But he neglected his parochial duties (and the childhood sweetheart who became his fiancée) for nearly five years in 
order to complete his first and best book: An Enquiry into the Extent and Stability of National Resources (1808). Chalmers told his diary that notwithstanding very unflattering reviews in the only two journals that noticed it, this book contained:

discussions of permanent importance; and not a person who is profoundly versant in the writings of Dr Smith who does not see that if my principles are found to be conclusive, they will give a wholly different aspect to the science of political economy.

(Hanna 1849-52: I, 136)

It was the total and unmerited failure of that ambitious work, combined with sickness and the collapse of his disastrous love affair, that precipitated a nervous breakdown during the winter of 1810-11. At that point he experienced a sudden and powerful evangelical conversion, from which he emerged a new man, quickly becoming the most famous preacher in Scotland (Brown 1982: 43-56).

But it was not until 1815 that Chalmers moved to a large urban parish in Glasgow, the Tron Kirk, and first witnessed 'the problem of poverty in industrial cities'. From the outset, his strategy was to revitalise the parochial community of pre-industrial Scotland, and to apply the 'moral paternalism' he had developed at Kilmany after his conversion to the outwardly different circumstances of a Glasgow slum. The lower orders were to be converted, one by one, to the faithful practice of a Protestant Christianity that would equip them to become useful and prosperous members of the commonwealth. Stewart J. Brown (1982) has shown how Chalmers's vision of a 'Godly Commonwealth' informed his social ministry in Scotland from 1812 to his death. But Boyd Hilton (1988: 87 et passim) has correctly pointed out that though Chalmers was indeed a 'moral paternalist' he was at the same time something entirely new in Scottish ecclesiastical circles: he was an 'economic individualist' believing strongly in laissez-faire and the efficacy of the market. The analysis of Chalmers's political economy set out in this chapter outlines the rational basis of this novel combination.

Though it is indeed the case, therefore, that some of Chalmers's economic writing after 1815 has reference to urban poverty - and a great deal more of it to poverty in general - we are obliged to conclude that his fascination with political economy was intellectual, not pastoral or political. He gave himself up gladly to the seductive power of what we now call 'economic analysis' and it is not too fanciful to think of him as the David Ricardo of Scotland. When Chalmers was mistaken in his social doctrine it was for exactly the same reasons as Ricardo: from a willingness to apply the policy implications of a rigorously specified model at full, long-run equilibrium to the vastly more complex social reality from which it had been abstracted. 
In what follows, therefore, we must first consider Chalmers's most considerable contribution to economic analysis (1808) and his subsequent development of the ideas contained in that book. We shall then be equipped to understand the analytical aspects of the project that he shared with T. R. Malthus of improving the condition of the poor by 'moral and religious teaching'; and why Karl Marx found it necessary to evade their analysis and rely on invective alone in his attempt to discredit it. At that stage we can examine and appraise Chalmers's most intemperate indulgence of the 'Ricardian vice': his purely economic argument for the establishment of the national Church. The final sections contain a summary appraisal of Chalmers's strengths and weaknesses as an economist, and the relation of his work to that of his contemporaries and successors in Scotland and abroad.

\section{Chalmers and 'classical political economy'}

A 'History of Economic Thought' Web site associated with the New School University in New York (http://cepa.newschool.edu/het/home.htm) includes Chalmers in a list of 'British anti-classical economists', along with Lauderdale, Malthus, Torrens, Bailey and Poulett Scrope. It is clear so far as Malthus and Chalmers are concerned that this egregious misperception, which is still widespread, depends upon obsolete secondary literature. No one who has actually read Malthus and Chalmers can fail to recognise that the analytical core of their work is at least as congruent with what Samuelson (1978) has labelled the 'canonical classical model' of political economy as that of J. S. Mill and Karl Marx (Waterman 1991b, 1992).

Like Ricardo, Chalmers conducted his analysis by abstracting a 'strong' case, considering its properties, then gradually relaxing assumptions. National Resources begins with a model of a closed economy, later generalised for trade. We may study his method by considering only the simple case.

There are three sectors: Agriculture (A); 'Secondary' (S) producing the 'second necessaries of life' such as clothing and shelter (1808: 4-6); and 'Disposable' (D), corresponding closely to Smith's 'Unproductive' sector, producing services and luxury goods. There exists a socially determined, culturally relative, subsistence real wage $w=f+c$, where $f$ is the biologically determined food requirement taken to be a constant of nature, and $c$ is the food-exchange value of the (merely customary) per-capita 'second necessaries of life'. When the market real wage $W$ is greater than $w$, population (work-force, and employment, all assumed to be the same) will increase and vice versa. But 'the price of labour diminishes as the number of labourers is increased, and will at last sink to that level at which it remains stationary' (ibid.: 5, see also 255 et passim). Hence $w$ is a (stationary) equilibrium wage, corresponding to Smith's 'natural price of labour' 
in the stationary, or 'dull', state (Smith 1776: I.viii.15-22, 39-43); and the equilibrium combination of real wage, population, work force and employment is stable.

Because Agriculture affords more food than is necessary to feed its producers and to supply them with the purchasing power to buy S-goods (Chalmers 1808: 3-4) a surplus exists, some part of which is required to pay profits to A sector capitalists, the remainder constituting rent. Landlords and A-sector capitalists, having relatively negligible consumption in total, spend the surplus on D-goods; capitalists in S and D sectors, like those in the A sector, (re-) spend their profits on D-goods (ibid.: 174), generating further employment, profit and wages therein. Workers in all three sectors eat part of their wages and (re-) spend the balance, generating further employment, wages and profits in the S sector (ibid.: 14-15). There is evidently a convergent process by which the entire annual food production is consumed, having brought about successive ever decreasing 'rounds' of employment, wages and profits in the D and S sectors. At equilibrium 'the population of a country is never far short of all the subsistence produced in it' (ibid.: 2) and all food produced must be eaten. Figure 10.1 illustrates intersectoral flows in Chalmers's closed economy model.

Demand for labour in the D sector is determined by rent and profits in all three sectors. These can be spent at will on various combinations of services and luxury goods. Without government, the demand of property owners determines the composition of D-sector output. Chalmers now aggregates all D-sector goods except defence as 'luxuries', and puts himself

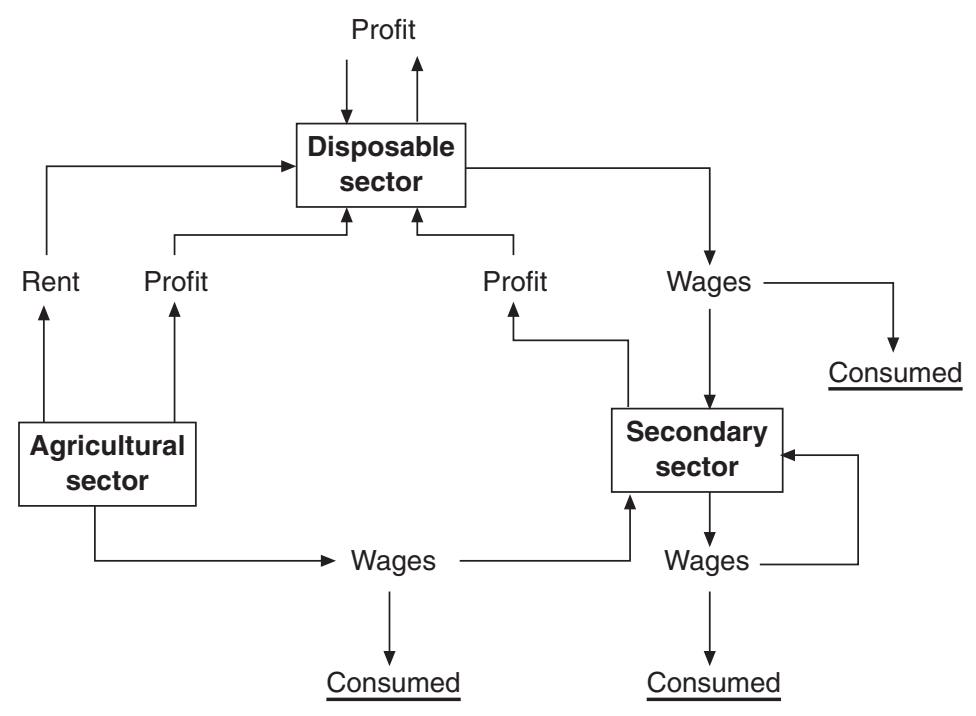

Figure 10.1 Inter-sectoral flows in Chalmers's 1808 model. 
in the position of a rational 'proprietor' (in time of war). 'I balance the enjoyment I derive from security, with the enjoyment I derive from the luxuries I have been forced to abandon' (ibid.: 38). Each 'proprietor' experiences a subjective trade-off between 'luxuries' and 'security', and 'the parallel exactly holds for the country at large' (ibid.). With a government (constrained by a balanced budget, assumed but not made explicit), taxation may be used to divert power over the 'disposable' population away from 'proprietors' into the hands of the executive, which may then use that power to 'allure' some of the D-sector population 'from their present employment in the service of private individuals, to the new employment of soldiers in the service of the state' (ibid.: 30). Chalmers composed his first work during an anxious phase of the French wars and its object was to show that Britain's 'national resources' were adequate to counter the 'furious and malignant despotism' of Bonaparte. It may be regarded as a vast and sophisticated elaboration of a cryptic utterance of Adam Smith:

When for defraying the expence of government a revenue is raised within the year from the produce of free or unmortgaged taxes, a certain portion of the revenue of private people is only turned away from maintaining one species of unproductive labour, towards maintaining another.

(Smith 1776: V.iii.48)

Now Chalmers's argument depends on the existence and stability of population equilibrium noted above, which are guaranteed by two assumptions: (1) there is a 'general standard of enjoyment' in every country and if wages fall below this standard 'the population of a country declines' (Chalmers 1808: 5); (2) 'the price of labour diminishes as the number of labourers is increased' (ibid.). The first assumption was taken for granted by all eighteenth-century economic thinkers and had lately been given great prominence by Malthus (1798). The second assumption - which is the 'new wrinkle' distinguishing nineteenth-century 'classical' political economy from the pre-classical analyses of Hume, Tucker, Steuart, Adam Smith, Paley and their French contemporaries - was implied by Malthus's 'ratios' of food and population growth (Waterman 1992). But it was not fully worked out until the simultaneous discovery seventeen years later by Malthus (1815), Ricardo (1815), West (1815) and Torrens (1815) of the 'Ricardian' theory of rent. Nowhere in National Resources is that assumption explained or defended.

I have elsewhere shown (Waterman 1991b) that over the next eighteen years Chalmers gradually came to understand the Ricardian 'hard core' of the canonical classical model. The process was much aided by his appointment as Professor of Moral Philosophy at St Andrews (1823-28), which relieved him for a time of the parochial duties he had now begun to take 
very seriously. Library records show that in 1824-25 he borrowed books by James Mill, Ricardo (Principles), Say, Sismondi, Spence, Bicheno, Tooke and McCulloch $(R B, 1821-32: 476-82 \mathrm{ff}$.$) , in preparation for the course of$ lectures in political economy that he offered for the first time in 1825-26 (Waterman 2005). His diary records his struggles to master Ricardo in August 1825 and again in June 1826 (Hanna 1849-52: III, 92, 93, 103). A long footnote in the third volume of his Christian and Civic Economy of Large Towns (Chalmers 1826: 125-8) summarises Chalmers's economic analysis at that stage of his thinking. It shows that he had by then thoroughly grasped the concepts of diminishing returns and rent, and had come to see what was implied - but only implied - in Malthus's first Essay on Population (1798), which Chalmers had certainly read by 1808: namely that it is diminishing returns to the variable factor in agriculture which explains why 'the price of labour diminishes as the number of labourers is increased'. Manuscript notes prepared in 1825 for his lectures (CHA 6.8.5, 6.9.1) summarise the 'Chief Peculiarities of the Course in Political Economy' in twenty-six propositions that differ only in minor detail from the slightly longer version at the end of his Political Economy (1832a: 551-66). The 'Peculiarities' are formalisations or amplification of the 1808 model when the latter is correctly viewed as depending upon diminishing returns. And by 1832 Chalmers came to believe - or at any rate to pretend - that he had really understood all this in 1808 (Waterman 1991b: 234).

\section{Exalting the taste of the people}

'Accomplish a change in the general taste of the people, and you accomplish a corresponding change in the wages of labour' (Chalmers 1808: 259). Chapter VII of National Resources considered 'the Effects of Taxation upon the Labouring Classes of the Community'. Chalmers sought to show that 'a tax... has no effect on the wages of labour' (ibid.: 262); which is true only if labour is perfectly mobile and if population and work force adjust immediately to any change in the real wage from its stationary equilibrium value. In the course of an analysis implicitly based on these assumptions, Chalmers identified what was to become the dominant theme of his distinctive contribution to political economy: 'we are still looking objectively to the enlargement of resources in the outer world of matter, instead of looking subjectively to the establishment of habit and principles in the inner world of mind' (Chalmers 1832a: 71). In the first work written after his evangelical conversion Chalmers declared that 'Could we reform the improvident habits of the people, and pour the healthful infusion of Scripture principle into their hearts, it would reduce the existing poverty of the land to a very humble fraction of its present extent' (1814: 14-15). For the rest of his life it was the chief object of his analytical work to demonstrate that 'for the economic well-being of a people, their moral and religious education is the first and greatest object 
of national policy' (1832b: iv). The first to have developed these ideas convincingly were Malthus and J. B. Sumner (Waterman 1991a), and the former regarded Chalmers as his 'ablest and best ally' (CHA 4.21.51, f. 2).

Let us specify a 'Malthusian' population adjustment function, where $N$ stands for population and/or work force and/or employment and $\mathrm{g}$ is the logarithmic growth-rate operator. $W$ and $w$ are defined as above: $W$ is the market rate of real wages, $w$ that real wage at which population is stationary.

$$
\mathrm{g} N=a(W-w), a>0
$$

Then if the market wage-rate is in turn a decreasing function of population,

$$
W=W(N), W^{\prime}<0
$$

with an inverse function, $N=N(W), N^{\prime}<0$, then $\mathrm{d}(\mathrm{g} N) / \mathrm{d} N=a W^{\prime}<0$. Hence a stable equilibrium exists at which $W^{*}=w$ and $N^{*}=N(w)$. This is the core of Chalmers's macroeconomics in National Resources. It is therefore obvious (if not tautologous) that since $w$ is an index of 'the Taste of the People', 'exalting' $w$ will 'accomplish a corresponding change in the wages of labour', all other things remaining the same. It is also evident that an increase in $w$ will bring about a reduction in $N$ at equilibrium. Chalmers, and to a lesser extent Malthus and Sumner, believed that $w$ could be increased by 'moral and religious education' of the lower orders.

The next step in Chalmers's argument is a theorem on income distribution of the highest ideological importance. For by 'exalting the taste' of the people, 'you add to the extent of that population who work for their secondary enjoyments. You therefore trench on the disposable population, on that population that is employed in administering to the higher luxuries of the wealthy...' (Chalmers 1808: 258). That is to say, it lies within the power of the 'class of labourers' as a whole to appropriate some part of the national surplus at the expense of 'proprietors'.

Let total food production be $F$ and the labour cost of production $N_{a} W$, where $N_{a}$ is population/work force/employment in the Agricultural sector. Then the proprietors' surplus,

$$
V=F-N_{a} W
$$

If $W$ is increased because of an autonomous rise in $w$, and if $F$ and $N_{a}$ are assumed to be unaffected when the A-sector population is enriched by the reduction in $V$, then the gains are distributed to labourers in the other two sectors through increased spending on S-goods and higher wages. However, it has already been seen that stability depends on Chalmers's (unexplained) assumption that total population will fall as $\left(W^{*}=w\right)$ increases exogenously; and if $N_{a}$ shares in this decline the effect upon $V$ of 
rising $W$ will be ambiguous. Moreover it seems obvious that food production will be some increasing function of $N_{a}$. We can investigate the validity of the redistribution theorem, therefore, only by making explicit the relations among $F, N_{a}, N$ and $W$. Chalmers failed to acknowledge in 1808 that food production depends on population, hence at that stage his model was incomplete and suggestive only.

However, by means of the Ricardian 'canonical' analysis which Chalmers had mastered by 1825 his theorem can be proved. Consider the simplest possible case in which food is produced by labour alone under conditions of diminishing returns, and in which competition drives the real wage to equality with the marginal product of labour.

$$
F=F\left(N_{a}\right) ; F(0)=0, F^{\prime}>0, F^{\prime \prime}<0
$$

Define the proprietors' surplus as

$$
V \equiv F\left(N_{a}\right)-N_{a} F^{\prime}\left(N_{a}\right)
$$

and note that in stationary equilibrium

$$
W^{*}=F^{\prime}\left(N_{a}^{*}\right)=w
$$

Then by differentiation of (5) and (6) and rearrangement, we obtain

$$
\mathrm{d} V^{*} / \mathrm{d} w=-N_{a}^{*}<0
$$

An increase in the socially determined 'subsistence' wage will reduce the proprietors' surplus in stationary equilibrium.

It is clear that each individual labourer's share will be increased at the expense of the proprietors, and also that the latters' absolute share of total income will fall (7). But whether the relative share of the class of labourers as a whole will rise as $w$ is increased is ambiguous when the general, diminishing-returns production function described in (4) is used. This is because as $w$ rises both $F^{*}$ and $N_{a}^{*}$ must fall, hence what happens to the relative share of labour, $N_{a}^{*} w / F^{*}$ is uncertain. However, when a logarithmic production function (implied by Malthus's 'ratios') is used in place of (4) the ambiguity disappears. An increase in $w$, brought about by 'moral and religious education' let us suppose, increases the equilibrium real wage, reduces the property owners' surplus, and increases the relative share of workers as a class at the expense of that of landlords. Chalmers was a faithful disciple of Malthus and thoroughly acquainted with the latter's works, but there is no trace in any of his writings which allows us to suppose that he was aware of the implicit logarithmic production function. However, it has been shown that by the use of this assumption we can make sense of Chalmers's argument not only in this simplest possible 
model but in the more general context in which capital is required for production (Waterman 1995: 39-44), and also in Chalmers's original three-sector model (Waterman 1991b: 238-9). When $w$ increases, the relative shares of both labourers and 'cultivators' (i.e. capitalists) increase at the expense of landlords. In the three-sector model both agricultural and disposable populations will fall as $w$ rises, and the secondary population will rise at least relatively and probably absolutely, which is what Chalmers (1808: 258) had taken for granted in his first work.

Now it is obvious that these theorems, if correct and applicable, must utterly subvert Karl Marx's entire theoretical and political enterprise. For Marxian 'exploitation' rests upon the assumption that workers have no power short of brute force of wresting any part of surplus value from the owners of property. Moreover, the principle of population upon which the theorems are based is itself deadly to Marx's programme (Waterman 1998: 299-301), since by its operation 'socialism cannot abolish poverty, which has its cause in nature, but can only make it general' (Marx 1973: 23). Yet as Samuel Hollander (1984) has shown, Marx's own analysis of the relation between increasing organic composition of capital and the 'industrial reserve army' depends upon a disguised version of the principle of population.

Although 'Marx's usual practice was to provide an exhaustive critique of the fallacious doctrines of political economy' he was shrewd enough to see clearly that such would be impossible in this case. He therefore chose to rely solely on a smokescreen of calumny and derision, which in the opinion of a sympathetic commentator was a 'conscious political choice' (Perelman 1985: 461, 483-5). Malthus and Chalmers were 'parsons': ergo they must have been 'servitors' of 'the conservative interest'. Malthus was 'a master of plagiarism'. 'Parson Wallace, Parson Townsend, Parson Malthus, and his disciple, the arch-parson Thomas Chalmers' are condemned for their 'bungling interference'. Chalmers is reported to have had 'his suspicions as to Adam Smith's having invented the category of "unproductive labourers" solely for the Protestant parsons, in spite of their blessed work in the Lord's vineyard' (Marx 1954: 160, 333, 475, 495, 578-9, 605-6). Whether or not Marx really believed any of this himself, his casual libels have been faithfully recycled by several generations of devotees.

\section{The political economy of Church establishment}

When Chalmers's appointment at St Andrews came to an end in 1827 he was pressed to accept the Chair in moral philosophy at the newly created University of London, but this he declined in favour of the Chair in divinity at the University of Edinburgh. Admission to his inaugural lecture was by ticket only, a large crowd had assembled in snow and sleet two hours early at 9.00 a.m., and extra police were summoned to guard the entrance 
(Brown 1982: 174-83). For by this time Chalmers was a national figure, dominating the General Assembly of the Kirk, lecturing and preaching in London, Belfast, Bristol and other large centres, testifying before parliamentary committees, and meeting with Cabinet ministers, bishops and grandees, both Whig and Tory. He was elected Moderator of the General Assembly in 1832. The merchants of Glasgow gave their clerks half-holidays to attend his lectures. He had indeed become an international figure, receiving fan-mail from the United States as early as 1828 (CHA 4.94.1-53). Originally 'Free Presbyterian' Churches all over the English-speaking world still bear his name.

Chalmers's fame among the powerful in Britain rested upon a vigorous defence of Church establishment at a time when that venerable institution was under strong attack in England and Ireland from radical reformers. His book on Literary and Ecclesiastical Endowments (Chalmers 1827) attracted the attention of Richard Whately and other influential figures in the Church of England (Waterman 1991a: $217 \mathrm{ff}$.), and in 1835 he was awarded an honorary DD by the University of Oxford, the first nonAnglican ever to be so distinguished. Chalmers continued to occupy his Chair at Edinburgh, never again returning to the parish ministry but becoming increasingly engaged in Church and national politics. After the Disruption of the Kirk in 1843, largely brought about by his own intransigence (Brown 1982: 282-349), Chalmers quitted the University of Edinburgh to become Professor of Divinity and Principal at the newly founded Free Kirk seminary, New College, Edinburgh, where he remained until his death four years later. It is an irony of ecclesiastical history that the most strenuous advocate of establishment in the early nineteenth century should have ended his days as the spiritual leader of a schismatical sect.

Though the argument for establishment appears in many of Chalmers's publications in the 1820 s and 1830 s it is presented in its most complete form in his lectures to divinity students at Edinburgh, written up and published as On Political Economy in Connexion with the Moral State and Moral Prospects of Society (Chalmers 1832a). It was the purpose of this book 'to demonstrate the futility of every expedient, which a mere political economy can suggest for the permanent well-being of a community' (ibid.: 420). Successive chapters show that the permanent, or equilibrium condition of the 'Labouring Classes' is invariant with respect to foreign trade, taxation, tithes, laws of inheritance, emigration and the Poor Laws: except in so far as the last-named may make things worse by working to decrease $w$. Only 'moral and religious education' would do, and only an established Church could provide this effectively.

Chalmers was of course familiar with Adam Smith's answer to Hume's case for establishment (Smith 1776: V.i.g.1-6, 8) which recognised the economic value of religion but argued that this would be most efficiently supplied by free competition among 'sects' (Anderson 1988). But with remarkable analytical insight Chalmers perceived that there would be 
'externalities' in religious markets: the social benefits of religion would exceed the value captured by its market price. Thus with a free market the urban middle classes, who are the chief producers and consumers of religion, would provide proprietary chapels for their own use, but the urban poor and the rural population would be neglected (Brown 1982: 174; Hanna 1849-52, III: 267, 266). Therefore 'a religious establishment' would be 'the best machine for the extensive Christianization of the families of the land' (Chalmers 1832a: 436). I have analysed Chalmers's economistic case for establishment of the national Church in a previous study (Waterman 1991a: 230-40). What follows is a summary and in some places a direct quotation of that work. The sequence of propositions 4, 5, 6 and 7 , which lies at the heart of the exposition, has been formalised in previous sections of this chapter.

The argument, which is complex, can be reduced to a chain of eleven putatively causal links.

1 A nationally established Church can teach a common religion more efficiently than a free market of competing 'sects'.

2 Religion inculcates morality and self-restraint, thereby 'exalting' the 'Taste of the People'.

3 Morality and self-restraint, consequent upon such exaltation of taste, cause the poor to defer marriage until they see a reasonable prospect of supporting a family.

4 Deferred marriages reduce population.

5 Reduced population, and correspondingly reduced work force, increase the real wage, which is the net outcome of the exaltation of taste.

6 An increase in the real wage (at equilibrium, when the return to capital is at the minimum required to maintain the capital stock in optimum relation to the work force) must be at the expense of rents.

7 Hence a portion of the national surplus is transferred from the (rich) proprietors to the (poor) labourers without encroaching on the share of capitalists.

8 The consequent prosperity of the class of labourers reduces social unrest and thereby legitimatises, or at any rate safeguards, private property rights.

9 It also eliminates pauperism and the need of a compulsory levy upon property for poor relief.

10 Because the Poor Laws are an ineffectual means of relieving the poor and actually increase pauperism (about which Malthus and Ricardo were in full agreement with Chalmers) an easing of the burden of poor relief would more than offset the transfer of part of the national surplus from rents to wages resulting from 'moral restraint'.

11 Therefore the cost to society of an established Church is worth incurring for two reasons: first, because it protects property; second because it reduces the net burden upon proprietors of poor relief. 
Such an argument is only as strong as its weakest link. Propositions 4, 5, 6 and possibly 7 rested upon a generally acceptable economic analysis; and 8 was, and perhaps still is, conventional wisdom. But what if the empirical judgements underlying 9 and 10 were doubtful or simply wrong? More seriously, and crucial for the validity not only of Chalmers's argument but of his entire life work: even if we accept 1 and 2, what of 3 ? Is 'moral and religious teaching' the only way to exalt the taste of the people? Critical consideration of 5 , which may well be formally true, leads us to doubt whether it is.

The clearest and most powerful statement of this objection came from Chalmers's fellow Scotsman and economist, John Ramsay McCulloch, by that time Professor of Political Economy at London. McVey Napier, who had solicited Chalmers's help in editing the Edinburgh Review, had sent Political Economy to McCulloch for notice in that influential publication, with special instructions to treat it with the highest respect (Brown 1982: 200). But the radical McCulloch privately regarded the book as 'a tissue of abominable absurdities' and Napier eventually agreed to publish his formally courteous but mercilessly adverse appraisal.

Chalmers's crucial results 'can take place only on the supposition that the population is instantaneously, or at least very speedily, adjusted to variations in the supply of food and other accommodations' (my italics). But suppose a onceand-for-all increase in the capital stock raising the demand for labour and driving up the real wage. Any such new capital formation may and in fact does occur from 'improvements in agriculture and the arts', and from international trade, not to mention an exogenous increase in the degree of Smithian 'parsimony'. It might take 'a period of eighteen or twenty years' before population and work force adjusted fully; and in that time labourers' 'notions as to what was required for their comfortable or decent support, would consequently be raised'. Hence 'the education of circumstances' alone may produce that 'transformation of taste and character' that Chalmers had correctly seen as necessary and sufficient for a permanent improvement in living standards. To put the matter brutally (which McCulloch refrained from doing), with an endogenous real subsistence wage, economic growth makes Church establishment redundant (ER 1832: 54-5, 59). Moral and religious education may be sufficient and in any case is a good thing in itself; but it is not necessary for 'exalting the taste of the people'. And policies to encourage economic growth are probably more reliable.

Most of the other notices, even that of the Tory Quarterly, were hostile or at any rate less than favourable. But McCulloch's was decisive, and Chalmers's reputation as a political economist went into decline. His Bridgewater Treatise (1833), which attempted to defend coexistence of the Divine Attributes ${ }^{1}$ by means of political economy was largely ignored. Only the high-church British Critic was guardedly sympathetic. Chalmers (1832b) had replied to McCulloch at book length but could not meet his 
central objection. This is because he failed to grasp the subtle idea of 'hysteresis' that David Hume (1994: 115-25) had adumbrated in his essay 'Of Money' (Berdell 1995). When a system in equilibrium is subjected to a prolonged constraint its parameters may become (temporarily) endogenous and change; thus when that constraint is removed new parameters will determine a new equilibrium configuration of dependent variables. McCulloch's review is distinguished not only for this powerful insight but also for his remarkable analysis of the importance of price elasticity of demand ( $E R$ 1832: 66). That he identified the former so clearly testifies to the continuity of analytic method in Scottish political economy.

\section{Chalmers as an economic analyst}

As early as 1808 Chalmers evinced remarkable gifts as an economic analyst, throwing out ideas and formulating - or at least partly formulating - concepts that in some cases were generally accepted only many decades later. Rational choice by a 'proprietor' between domestic security and private amenity at the margin (1808: 38), preferences of the representative proprietor as a social welfare or 'national interest' function capturing the trade-off between 'luxuries' and 'security', the production-possibility frontier implicit in the concept of 'disposable population' and the assumption of a balanced budget, the fiscal power of government to locate the economy at that point on this frontier that maximises social welfare, recognition of positive externalities in national defence (ibid.: 329-31), recognition that taxation must be compulsory because of free riders (ibid.: 36-7), rejection of the useless distinction between 'productive' and 'unproductive' labour, and an analytical distinction between the short and the long run (ibid.: 25, 27, 261) are only some of the more important of these. Even more remarkable perhaps was his perception that a tariffinduced diversion of domestic production and consumption from internationally traded to home goods need not reduce welfare if tastes change after, and because of, the switch - and the public comes to prefer home goods (ibid.: 141-6).

Had National Resources been brought to the attention of the newly emerging circle of political economists in England at that time it seems probable that Chalmers's great abilities would have been recognised and further developed by encouragement and mutual criticism. But unlike Malthus, in 1798 an equally obscure clergyman who had the good fortune to be published in London by Joseph Johnson, Chalmers was unlucky. Only Lord Selkirk was favourably impressed by the book, and began an appreciative review for 'the Edinburgh' which unfortunately he did not complete (Hanna 1849-52: III, 129). Had he done so the story of Chalmers's life might have been very different - as might also the history both of economic analysis and of the fortunes of the Church of Scotland.

But the wound inflicted by the contemptuous neglect of his first work 
went very deep and was never quite healed. For the rest of his life Chalmers maintained an increasingly combative attitude towards 'a mere political economy', and to virtually all its practitioners save Malthus. What may have been a life long tendency towards intellectual self-sufficiency and separatism was aggravated by the critical treatment he subsequently received. The notice of his Political Economy (1832) in the Eclectic Review is typical:

[for that book] has confirmed the impression produced by the Author's former writings on the subject of political economy, that his talents and turn of mind do not remarkably qualify him for such inquiries. He is by far too bold a thinker ... too sweeping a generalizer, to be correct in statements relating to complex subjects involving infinite details; too apt to suffer one great idea to fill up the whole field of his intellectual vision, to the exclusion of other objects which, being taken in, would have corrected his false perspective.

(Eclectic Review 1832: 2, 460)

Chalmers continued to generate brilliant insights in his later work. Recognition of diminishing returns and the implicit production function, for example, enabled him to formulate two highly important theorems on technical progress: 'descent of cultivation to inferior soils does not necessarily imply any descent in the circumstances of the labouring classes' (wrongly supposed by modern commentators to be in conflict with Ricardo); and with 'improvement in the methods of husbandry ... the standard of enjoyment may rise, and yet the income of landlords rise along with it' (Waterman 1991b: 232-3, appendix, paras 17, 18, 19, 20). But his habit of ignoring the criticism of others, together with his obtrusively homiletic style, had created too wide a gulf between Chalmers and most other economists for these contributions to be noticed and appreciated, or for Chalmers himself to pay much attention to the work of others after leaving St Andrews. It is revealing that his pro-Malthusian attempt to show the possibility of 'general gluts' in chapter V of Political Economy completely ignores the careful two-period analysis that Malthus himself had developed twelve years earlier (Malthus 1820: 352-5), and largely misses the point of the controversy. In 1827 Malthus had written to Chalmers of National Resources and Christian and Civic Economy that 'I think in both your publications you have pushed your principle too far' (CHA: 4.80.7). And on receiving Political Economy he wrote a long, friendly though guarded response, agreeing with much but distancing himself from two of Chalmers's most obviously reductionist theories: the claim that the burden of taxation fell solely on land, and 'the doctrine of the nonimportance of foreign commerce' (ibid.: 4.185.32). But by this time Chalmers was no longer in any real contact with the tiny fraternity of economists in England. 
Partly because of this, partly because of his increasing involvement in ecclesiastical politics in the 1830s and 1840s, Chalmers exerted far less influence upon political economy in his own time and later, and therefore has received far less recognition by subsequent generations of economists, than his great abilities and gargantuan output might otherwise have won. Of his former pupils at St Andrews only one, Patrick J. Stirling, two of whose undergraduate essays for Chalmers have survived (NLS: vol. X, ms. 14273, ff. 38-48; 2-36) achieved any considerable reputation as an economist (Waterman 2005). Stirling's Philosophy of Trade (1846) was 'commended by Dr Chalmers', noticed in the Westminster Review, the English Review, the Banker's Magazine and the London Literary Gazette, and a second edition published in London in 1847 (Allibone 1870). Stirling, who was a lawyer by profession, also published The Australian and Californian Gold Discoveries (Edinburgh 1853) and a translation of Bastiat's Harmonies of Political Economy (London 1860).

Among leading economists of his own day and after, Marx's well known caricature has already been noted. It is less widely realised that Marx cites Chalmers at various other places in the three volumes of Capital with at least as much respect as he accorded McCulloch and J. S. Mill.

From the latter's citations in Principles of Political Economy (1909), originally published in 1848, one year after Chalmers's death, it is clear that Mill at any rate was thoroughly familiar with his controversial predecessor's writing, and ready, in his usual fair-minded way, to recognise its virtues. In discussing the 'perpetual consumption and reproduction of capital' Mill acknowledges Chalmers handsomely:

this simple explanation was never given (so far as I am aware) by any political economist before Dr Chalmers; a writer many of whose opinions I think erroneous, but who always has the merit of studying phenomena at first hand, and of expressing them in a language of his own, which often uncovers aspects of the truth that the received phraseologies only tend to hide.

(Mill 1909: 75)

There follows a carefully nuanced, three-page discussion of the central argument of National Resources - that national defence should be financed by taxation rather than by borrowing. On this question Chalmers's 'views appear to me to be strictly just' (ibid.: 78). All Mill's other references are appreciative and respectful except for those which concern the most 'erroneous' of Chalmers's 'opinions': the over-productionist heresy that Chalmers shared with Malthus and Sismondi:

This error has been, I conceive, fatal to the systems, as systems, of the three distinguished economists to whom I have before referred, Malthus, Chalmers and Sismondi; all of whom have admirably con- 
ceived and explained several of the elementary theorems of political economy, but this fatal misconception has spread itself like a veil between them and the more difficult parts of the subject, not suffering one ray of light to penetrate. Still more is this same confused idea constantly crossing and bewildering the speculations of minds inferior to theirs.

(Ibid.: 562)

Mill was the last important economist to take Chalmers seriously. Now that Mill's Principles of Political Economy are no longer part of the formation of a professional economist, Chalmers has been lost to sight. His name does not appear in Marshall. Maynard Keynes (1936: 369) quoted a passage of Hobson that mentions Chalmers, but it never occurred to him to enrol the latter in his 'brave army of heretics' who 'preferred to see the truth obscurely and indeed imperfectly rather than to maintain error' (ibid.: 371). Nisbet (1964) provided a brief summary of some features of Chalmers's analysis that exaggerates its distance from the canonical classical model. The authors of more recent historiographic treatment (Hilton 1985; O’Brien 1987; Rutherford 2004) ignore both the analytical skills and achievements, and the analytical weakness and failures, of their subject. Only the encyclopedic Schumpeter appreciated Chalmers as theorist; but, misled perhaps by Chalmers's own rhetoric, sees him as 'thoroughly un-Ricardian'. Like J. S. Mill (but unlike his Harvard pupil, Paul Samuelson), he puts Malthus and Chalmers in one camp, Ricardo and James Mill in another. 'If it were possible to speak of a Malthusian school in general theory (which I doubt), Chalmers would have to figure as its McCulloch - which is, after all, not so left-handed a compliment as it may seem to the reader' (Schumpeter 1954: 487).

\section{Chalmers and Scottish political economy}

What then is the place of Thomas Chalmers in Scottish political economy?

In one respect at any rate, it is a little like the place of Lord Keynes in English political economy. He was the only internationally recognised public figure in the history of Scotland to achieve distinction as an economist. For more than two decades he compelled the often reluctant attention of Melbourne and Russell, Peel and Aberdeen. Thousands lined the streets of Edinburgh at his burial. The influence of Chalmers on economic policy debates in the UK Parliament has been documented by Boyd Hilton (1988). More has been written about him in English, especially by way of biography, than any other nineteenth-century economist save Marx. Adam Smith and David Hume were well known as 'philosophers' in France and England but were essentially private men, playing little part if any in great affairs of state. No other Scottish economist has enjoyed more than merely professional fame. 
He was also the last major economist to live and work in Scotland. It is not altogether far-fetched to see Chalmers as a very late chrysanthemum of the Scottish Enlightenment, withered suddenly by sharp evangelical frost in 1810. James Mill and J. R. McCulloch, contemporary Scottish economists of comparable intellectual weight, early chose 'the fairest prospect in Scotland' and worked in England, Mill from 1802 and McCulloch from 1828. John Rae emigrated to Canada in 1822.

And Chalmers was a pioneer in the teaching of political economy in Scottish universities. Dugald Stewart's annual lectures at the University of Edinburgh, beginning in the academic year 1779-80, were the first ever to be devoted, ostensibly and exclusively, to the new science. But they were more in the nature of what would now be called 'outreach', intended for and attracting an audience drawn from the general public and which included a number of distinguished visitors from England. McCulloch gave somewhat similar public lectures in Edinburgh before moving to London. Long before these, of course, Adam Smith had included much of what would later be called 'political œconomy' in his Glasgow University lectures on 'Police'. So far as I can discover, however, the courses in political economy that Chalmers offered during his last two years at St Andrews (1826-27, 1827-28) were the first in Scotland to be described as such, and recognised by the university as part of the formal undergraduate programme in Moral Philosophy. By contrast with England and Ireland, there were no professorial Chairs in political economy in Scotland for several more decades. (See further Chapter 12 in this volume.)

Thomas Chalmers appears to have been the only professor in the world to offer a course of lectures in political economy to divinity students.

\section{Note}

1 Orthodox monotheistic theology affirms that God is: (a) all-powerful, (b) allknowing, (c) all-wise, (d) all-good. The evidence of natural and moral evil in the universe calls into question the coexistence of the attributes and therefore the coherence of orthodox theology. The so-called 'problem of evil' is thus a fundamental challenge to Christian belief. Attempts to supply solutions are known as 'theodicy'. At least since Adam Smith (Waterman 2002) and possibly since Boisguilbert (Faccarello 1999) economic theory has occasionally been deployed in this enterprise. Chalmers (1833) attempted the task that Whately had set himself but did not accomplish: to use political economy in the way in which Paley had used biological science in his Natural Theology (Waterman 1991a: 212, 246-51). A present-day theologian has characterised classical political economy as 'heretical theodicy' (Milbank 1990). 


\section{References}

\section{Manuscript sources}

Manuscript sources for the study of Thomas Chalmers are, first and foremost, the Chalmers collection in New College, Edinburgh. St Andrews has a few hundred letters not in New College, some notes of Chalmers's Moral Philosophy lectures (1826) by F. A. S. Knox, and also the library records, which list all the books Chalmers borrowed both as an undergraduate (1791-99) and as a professor (1823-28). The two undergraduate essays written for Chalmers and one or two other items are held in the National Library of Scotland. References to manuscript material used in this chapter are identified as follows: CHA Chalmers collection in New College, Edinburgh; NLS Manuscript collection in National Library of Scotland; $R B$ Receipt Book of the Library of St Andrews University.

\section{Printed sources}

Allibone, S. Austin (1870) A Critical Dictionary of English literature and British and American Authors, living and deceased, from the earliest Account to the latter half of the Nineteenth Century II, Philadelphia: Lippincott.

Anderson, Gary M. (1988) 'Mr Smith and the Preachers: the Economics of Religion in the Wealth of Nations', Journal of Political Economy 96, 5: 1066-88.

Bastiat, F. (1860) Harmonies of Political Economy, translated by P. J. Stirling, London.

Berdell, J. F. (1995) 'The Present Relevance of Hume's Open-Economy Monetary Dynamics', Economic Journal 105: 1205-17.

Brown, S. J. (1982) Thomas Chalmers and the Godly Commonwealth in Scotland, Oxford: Oxford University Press.

Carlyle, Thomas, letter to William Hanna (n.d.), cited at: http://www.newble. co.uk/chalmers/quotes-html.

Chalmers, Thomas (1808) An Enquiry into the Extent and Stability of National Resources, Edinburgh: Moir.

- (1814) The Influence of Bible Societies on the Temporal Necessities of the Poor, Cupar: Tullis.

- (1821-26) The Christian and Civic Economy of Large Towns I, 1821; II, 1823; III, 1826, Glasgow: Chalmers and Collins.

- (1827) On the Use and Abuse of Literary and Ecclesiastical Endowments, Glasgow: Collins.

- (1832a) On Political Economy in Connexion with the Moral State and Moral Prospects of Society, Glasgow: Collins.

- (1832b) The Supreme Importance of a Right Moral to a Right Economical State of the Community, Glasgow: Collins.

- (1833) On the Power, Wisdom and Goodness of God, as Manifested in the Adaptation of External Nature to the Moral and Intellectual Constitution of Man (Bridgewater Treatise I), 2 vols, London: Pickering.

Faccarello, Gilbert (1999). The Foundations of Laissez-faire: the Economics of Pierre de Boisguilbert, London: Routledge.

Fontana, Biancamaria (1985) Rethinking the Politics of Commercial Society: the Edinburgh Review, 1802-1832, Cambridge: Cambridge University Press. 
Hanna, William (1849-52) Memoirs of the Life and Writings of Thomas Chalmers, DD, $L L D, 4$ vols, Edinburgh: Sutherland \& Knox.

Hilton, Boyd (1985) 'Chalmers as a Political Economist', in A. C. Cheyne (ed.), The Practical and the Pius: Essays on Thomas Chalmers, 1780-1847, Edinburgh: St Andrews.

(1988) The Age of Atonement: the Influence of Evangelicalism on Social and Economic Thought, Oxford: Clarendon Press.

Hollander, Samuel (1984) 'Marx and Malthusianism: Marx's Secular Path of Wages', American Economic Review 74, 1: 139-51.

Hume, David (1994). Political Essays, edited by K. Haakonssen, Cambridge: Cambridge University Press.

Keynes, J. M. (1936) The General Theory of Employment, Interest and Money, London: Macmillan.

[Malthus, T. R.] (1798) An Essay on the Principle of Population as it affects the Future Improvement of Society, with Remarks on the Speculations of $\mathrm{Mr}$ Godwin, M. Condorcet, and other Writers, London: Johnson.

Malthus, T. R. (1815) An Inquiry into the Nature and Progress of Rent, and the Principles by which it is Regulated, London: Murray.

— (1820) Principles of Political Economy considered with a View to their Practical Application, London: Murray

Marx, Karl (1954) Capital: A Critique of Political Economy (translated by S. Moore and E. Aveling, edited by F. Engels) I, Moscow: Progress Publishers.

— (1973) 'Critique of the Gotha Program', in Selected Works in Three Volumes by Karl Marx and Frederick Engels, Moscow: Progress Publishers.

[McCulloch, J. R.] (1832) 'Dr Chalmers on Political Economy', Edinburgh Review 66: 52-72.

Milbank, John (1990) 'Political Economy as Theology and Agonistics', in Theology and Social Theory: Beyond Secular Reason, ch. 2., Oxford: Blackwell.

Mill, John Stuart (1909) Principles of Political Economy with some of their Applications to Social Philosophy, edited by W. J. Ashley, London: Longmans.

Nisbet, J. W. (1964) 'Thomas Chalmers and the Economic Order', Scottish Journal of Political Economy 11: 151-57.

O'Brien, D. P. (1987) 'Chalmers, Thomas', in J. Eatwell, M. Milgate, and P. Newman (eds), The New Palgrave: A Dictionary of Economics, London: Macmillan.

Perelman, Michael (1985) 'Marx, Malthus and the Organic Composition of Capital', History of Political Economy 17, 3: 461-90.

Ricardo, David (1815) An Essay on the Influence of the Low Price of Corn on the Profits of Stock shewing the Inexpediency of Restrictions on Importation: With Remarks on Mr Malthus' two last Publications: 'An Inquiry into the Nature and Progress of Rent'; and 'The Grounds of an Opinion on the Policy of restricting the Importation of Foreign Corn, London: Murray.

- (1817) On the Principles of Political Economy and Taxation, London: Murray.

Rutherford, Donald (2004) 'Chalmers, Thomas (1780-1847)', in D. Rutherford (ed.), Biographical Dictionary of British Economists, Bristol: Thoemmes Continuum.

Samuelson, P. A. (1978) 'The Canonical Classical Model of Political Economy', Journal of Economic Literature 16: 1415-34.

Schumpeter, J. A. (1954) History of Economic Analysis, New York: Oxford University Press.

Smith, Adam (1976) An Inquiry into the Nature and Causes of the Wealth of Nations, 
edited by R. H. Campbell, A. S. Skinner and W. B. Todd, 2 vols, Oxford: Oxford University Press.

Stirling, Patrick J. (1846) The Philosophy of Trade; or, Outlines of a Theory of Profits and Prices, Edinburgh.

— (1853) The Australian and Californian Gold Discoveries, Edinburgh.

Torrens, Robert (1815) An Essay on the External Corn Trade, London: Hatchard.

Waterman, A. M. C. (1991a) Revolution, Economics and Religion: Christian Political Economy, 1798-1833, Cambridge: Cambridge University Press.

— (1991b) " "The Canonical Classical Model of Political Economy" in 1808, as viewed from 1825: Thomas Chalmers on the "National Resources"', History of Political Economy 23, 2: 221-41.

_ (1992) 'Analysis and Ideology in Malthus's "Essay on Population”', Australian Economic Papers 31: 203-17.

- (1993) 'National Security in Classical Political Economy: a Neglected Contribution', History of Political Economy 25, 4: 739-44.

- (1995) 'Peasants, Population and Progress in Malthus and Chalmers', in E. L. Forget and R. A. Lobdell (eds), The Peasant in Economic Thought: 'A Perfect Republic', Cheltenham: Edward Elgar.

- (1998) 'Reappraisal of "Malthus the Economist", 1933-97', History of Political Economy 30, 2: 293-334.

- (2002) 'Economics as Theology: Adam Smith's Wealth of Nations', Southern Economic Journal 68, 4: 907-21.

— (2005) 'The Oldest Extant Undergraduate Essay in Economics?', Journal of the History of Economic Thought, forthcoming.

Watt, Hugh (1943) The Published Writings of Dr Thomas Chalmers, 1780-1847: A Descriptive List, privately printed.

[West, Edward] (1815) An Essay on the Application of Capital to Land, with Observations shewing the Impolicy of any great Restriction of the Importation of Corn, and that the Bounty of 1688 did not lower the price of it. By a Fellow of University College, Oxford, London: Underwood. 


\title{
11 John Rae
}

\author{
Douglas Mair
}

In the history of Scottish economic thought, John Rae must be regarded as an outlier. Although born in Aberdeen in 1796 and educated at Aberdeen and Edinburgh Universities, Rae emigrated to Canada in 1822. Despite travelling extensively in North and Central America and to Hawaii, Rae never returned to his native land and died in the United States, in 1872. Although he lived and worked in the Scottish expatriate society of eastern Canada for a number of years, he had no personal involvement with the milieu of the Scottish Enlightenment. The only 'Scottish' political economist with whom he is recorded as having corresponded was John Stuart Mill. Nor is there any record of correspondence with contemporary North American economic luminaries. Indeed, after the publication in 1834 of his Statement of Some New Principles on the Subject of Political Economy Exposing the Fallacies of Free Trade and Some Other Doctrines Maintained in the 'Wealth of Nations', Rae turned to other pursuits, including gold prospecting (he took part in the California gold rush of 1848), geology (his publications were highly regarded by contemporary geologists), philology (John Stuart Mill thought highly of his work), law (he was a land court judge in Hawaii) and the practice of medicine (he was a public health official in Hawaii and rendered medical services to the Hawaiian royal family).

It would be wrong to think of Rae as a 'one book wonder'. New Principles was written by a man whose occupation at the time was a schoolteacher in the Canadian backwoods. Its full title might suggest a tome written by a literal and metaphorical backwoodsman. It might suggest a polemic written by a protectionist lobbyist, a man with no formal education in political economy who yet had the blasphemous temerity to expose what he considered to be the 'fallacies' of the Wealth of Nations. Small wonder that Rae has never been widely recognised in the history of Scottish political economy, and, indeed, his name has often been confused with those of Adam Smith's biographer or of an Arctic explorer.

Yet New Principles won high praise from some of the great names of nineteenth and twentieth-century economics, including Senior, J. S. Mill, 
Fisher, Böhm-Bawerk, Schumpeter and Robbins. All of them have judged New Principles to be a work of great insight and originality. Rae has been identified by W. C. Mitchell (1934) as the founding father of American institutionalism. Schumpeter, who was never wholly enamoured of Smith, was fulsome in his praise of Rae:

For [in] one achievement, competent and workmanlike, yet of striking power ... in vision and originality, Rae far surpassed economists who were successful ... we must see in his work another Wealth of Nations or, more correctly, something that with ten additional years of quiet work, graced by an adequate income, could have grown into another and more profound Wealth of Nations.

(Schumpeter 1954: 468)

Rae was a man of considerable talent. As a student at Aberdeen University he displayed 'remarkable inventive attitudes' (James 1965: 9) and designed several ingenious pieces of scientific and engineering apparatus. From Aberdeen he went to Edinburgh University to study medicine and in his MD dissertation came to the conclusion that the physiological theories of his day were fundamentally false. Rae possessed what Schumpeter (1954: 468) described as an 'unmanageable wealth of ideas' on biology, philology, ethnology, geology and aeronautics. For financial and domestic reasons, Rae emigrated to Canada in 1822 and took up the post of village schoolmaster in Williamstown. He combined teaching with the practice of medicine and started to write articles on economic development for early Canadian literary journals. He was intimately involved with the large Scottish community in Canada.

By the early 1830s Rae had emerged as a leading spokesman for the Kirk and had established a reputation as a serious thinker on problems of economic development in Canada. This was a period when there was strong pressure in Britain to sever colonial ties. James Mill, another Scottish political economist featured in this volume, was prominent in arguing that the doctrines of international trade theory (comparative advantage and all that) applied equally to a colony as to a foreign country. There was a struggle in Canada in the 1820s and 1830s between the two major ethnic groups of immigrants. The French Canadians were indifferent or even openly hostile to maintaining the British connection and identified with the revolutionary and republican ideals of Europe and the United States. The Scottish Canadians, who were predominantly merchants, were committed to loyalty to the Crown and the mother country.

Rae aligned himself with the Scottish merchant faction, partly because he considered that the future of Presbyterianism in Canada depended on the preservation of its colonial status and partly because he considered that the Presbyterian work ethic had an important role in the development of a capital-hungry society. However, Rae's advocacy of Canada's 
colonial status was not based simply on religious or political considerations. He was already engaged on an extensive economic and statistical survey of Canada in the early 1830s and New Principles is very much a byproduct of that study. Rae went to Boston in 1834 to organise publication of New Principles. There existed in Boston at that time a vigorous protectionist lobby that was looking for an intellectual rationale to counter the laissez-faire liberalism of Adam Smith, whose ideas were very influential in the United States at that time. The extended title of New Principles provided the economic rationale sought by the protectionists.

From its initial publication, New Principles was misconstrued. It was perceived from the start as a polemic against free trade and its advocates, principally Adam Smith. Its subsequent history has done little to correct this misconception. New Principles was re-published in 1905 by C. W. Mixter in a clumsily rearranged edition entitled A Sociological Theory of Capital. Had it not been for the sterling efforts of R. W. James (1965), who produced a two-volume edition - one of the original text of New Principles and the other of Rae's correspondence - then it is highly probable that John Rae would have passed into total obscurity despite the recognition by a number of the leading figures of nineteenth- and twentieth-century economics that New Principles is indeed a work of rare quality.

\section{Rae and Smith}

In choosing his rather lengthy title for New Principles, Rae clearly saw his principal purpose to be to expose some of the fallacies of Wealth of Nations. In a sense, it is unfortunate that he chose to do so, because he diverted attention from some of the more important and profound aspects of New Principles. A careful comparison of Rae and Smith is provided by Hollander (1998), on which this section draws. Rae represented Smith as maintaining an unconditional laissez-faire stance regarding economic development. Smith and his followers were interpreted as holding the view that 'legislative interference [is] necessarily and essentially evil' (Rae 1834: 76-7). Rae, on the other hand, was concerned to show 'that the legislator may operate with advantage to the community, 1st in the transfer of foreign arts to his own country; 2nd in applying to useful purposes funds which would otherwise be dissipated in luxury' (Rae 1834: 362). Rae also found Smith guilty of inconsistency. Smith had recognised the importance of foreign sources of new technology and, as a consequence, the possibility that with appropriate intervention some industries might be established sooner than would otherwise be the case. Smith had also recognised the evil of luxury consumption. Smith was, therefore, according to Rae, inconsistent in not recognising beneficial intervention as a means of addressing these issues.

Essentially, Rae accuses Smith of committing a fallacy of composition. Smith applied 'terms and so also, reasonings, fitly applied to the operation 
of individuals in the preservation, enjoyment, and increase of wealth ... immediately to societies' (ibid.: 381). Rae's objection was that:

individuals, as well as nations, acquire wealth from other sources than mere saving from revenue: that skill is as necessary, and consequently as valuable, a co-operator with the industry of both, as either capital or parsimony and that therefore the expenditure which either may be called on to make to attain the requisite skill, is very well bestowed.

(Ibid.: 61)

Smith emphasised the importance of the division of labour in increasing efficiency and promoting national wealth. But Rae argued that there still remained a problem in Smith's argument:

the augmentation of the industry of the society is produced by an augmentation of its capital, and in no other manner, and its capital is augmented by saving from revenue and nothing else, and that, from the action and reaction of these principles on each other, the whole phenomena of the growth of national capital are deducible.

(Ibid.: 67-8)

Rae admitted that interference by the state would probably reduce the rate of capital accumulation in the short run, and, consequently, result in a lower level of capital stock than would otherwise have been the case. But state interference could raise the efficacy of the capital stock. Smith had ignored a potential role for the state in the generation of knowledge.

The sort of intervention Rae had in mind he described as: 'whatever promotes invention; 1. By advancing the progress of science and art within the community; 2. By the transfer from other communities of the sciences and arts there generated' (ibid.: 362).

Rae dismissed Smith's view that the case for international specialisation was of no consequence:

a country can often with ease, and at trifling expense, acquire the practical skill and knowledge of particular arts and manufactures which another possesses, and, by doing so, gain the advantage of procuring for itself the products of this skill and knowledge at home, instead of having to go abroad for them.

(Ibid.: 71-2)

He also dismissed Smith's rejection of infant-industry protection as an argument against intervention, going as far as to suggest that Smith held the notion of a more or less permanently fixed pattern of international trade.

From these quotations it might appear that the essential difference between Rae and Smith might be polarised into pro-intervention (Rae) and anti-intervention (Smith). Indeed, this is how Smith is characterised 
to the present day (e.g. Baroness Thatcher's (in)famous Sermon on the Mound to the General Assembly of the Church of Scotland in 1988, as debated in the pages of the Scotsman newspaper during May and June of that year). However, we are dealing with two far too intelligent and sophisticated political economists for this to be an appropriate characterisation. Rae does not advocate unrestricted intervention:

the question ... resolves itself into particulars, and the investigation of the political economist would seem to be confined to tracing out, from the principles of his science, rules determining when the passage of any art is practicable, and when the benefits derived from it will exceed, or fall short of the necessary expense of effecting the passage. It is not my intention to attempt a full discussion of these various particulars. It will be sufficient for the object in view, to enumerate the general advantages which such transfers produce, and to state some of the chief circumstances favourable, and some of the others adverse, to their success.

(Ibid.: 364)

Here we have an early statement of the basic principle of cost-benefit analysis. Rae clearly establishes that his position is 'the minimisation of the broad case for intervention based on spillover effects' (Hollander 1998: 212, emphasis in original). The case for intervention is not justified solely on the existence of spillover effects. Such effects 'must be justified for each case in its own terms' (ibid.: 215, emphasis in original).

Hollander (ibid.: 215-16) concludes that the differences between Rae and Smith on the development process are greatly exaggerated and for this Rae must accept a considerable part of the blame. Whether Rae did this for political purposes in an attempt to strengthen his case for protectionism is something on which we can only speculate. Smith is not wholly blameless either. Rae reproves Smith for getting too carried away by his vision of the philosophical system of the Wealth of Nations as an imaginary machine generating a clear, orderly and extensive view of a vast number of interesting and important facts that can be arranged and methodised to illuminate complex phenomena. But, as Rae observes:

The case, however, is completely altered, when the loose and popular principles on which such a system proceeds, are adopted as demonstrative axioms, the discoveries of real science, and are carried out to their extreme consequences. Their original purpose is then altogether changed, and instead of serving to bring before the mind a collection of facts, they lead it further and further away from truth and reality, into the barren and wearisome regions of mere verbal abstractions.

(Rae 1834: 350-1)

Here writes Rae the engineer, the scientist, the man of action. 


\section{Rae and the theory of capital}

New Principles is most definitely not the polemic that many have thought it to be. It contains important theoretical ideas that have had a major influence on the subsequent development of economic thought. Perhaps none is more important than Rae's theory of capital. The second book of New Principles is a theory of capital, conceived, according to Schumpeter (1954: 469), 'in unprecedented depth and breadth'. John Stuart Mill quoted copiously from Rae and went so far as to compare Rae's performance on accumulation with that of Malthus on population. Böhm-Bawerk (1959) rewrote Volume I of his Capital and Interest on the history and critique of interest theories specifically to acknowledge the influence of Rae, of whom he had been unaware at the time he wrote the first edition. Of Rae, Böhm-Bawerk wrote:

It was on the subject of the theory of capital, more specifically, that Rae held a number of exceedingly original and remarkable views, and those views exhibit unmistakeable similarity to views which were developed about half a century later by Jevons and myself. But it was those very parts of his doctrine which bear the stamp of originality, which his unheeding contemporaries passed by.

(Ibid.: 208)

Let us now look at these 'exceedingly original and remarkable views' a little more closely, drawing on Ahmad (1998). In New Principles, Rae placed much emphasis on the supply of capital, particularly its role in the economy. He identified three principal factors determining the supply:

1 The prevalence throughout the society, of the benevolent and social affections, or, of that principle, which, under whatever name it may be known, leads us to derive happiness, from the good we communicate to others.

2 The extent of intellectual powers, and the consequent prevalence of habit of reflection, and prudence, in the minds of the members of the society.

3 The stability of the conditions of the affairs of the society, and the reign of law and order throughout it.

(Rae 1834: 124)

These conditions are supposed to encourage the supply of capital (savings). Other factors promoting or militating against saving include income, uncertainty about the future, habit, fashion and vanity. Ahmad (1998: 114-15) concludes that Rae's discussion of the supply of capital is richer than that of Böhm-Bawerk and that Fisher (1982: 103) follows Rae almost exactly. 
On the theory of the demand for capital, Rae's contribution falls under two headings. The first is a clear statement of the principle of the diminishing marginal productivity of capital. The second is how 'invention' would shift upwards the marginal product curve of capital. Ahmad (1998: 116) describes Rae's contribution under both headings as 'very important and impressive'. Anticipating later developments by Menger (see Drakopoulos 1998) Rae introduces the concept of 'instruments' which consist of all goods, both consumption and production, and land. He then develops the concept of the 'order' of these instruments.

An instrument of value of 200 units of labour at one point of time yields an output at another point in time that has a value of 400 units of labour, twice that of the original input. If the time interval is one year, the 'order of the instrument' is A or 1, if two years it is B or 2 and so on. This is an alternative way of expressing the marginal product of capital. Ahmad (1998: 116) illustrates the equivalence in the following way. If $r$ is the marginal yearly rate of return on capital and $n$ is the order of the instrument, i.e. the number of years required for the value of the instrument to double, then $(1+r)^{n}=2$ gives the relationship between $r$ and $n$. If $n$ is known, the marginal product of capital is given as $r=2^{1 / n}-1 . r$ and $n$ are obviously negatively related. Rae clearly saw that, given technical knowledge, the marginal return to capital ultimately diminishes. But - and here he makes his most powerful contribution - he also recognised that invention will raise the marginal product curve of capital in the relevant range. Rae discusses various aspects of invention such as labour- or capital-augmentation, learning-by-doing or, as emphasised by Ahmad (ibid.: 117), 'perhaps the most significant, the externalities generated by invention' (emphasis in original).

Thus, according to Ahmad (ibid.: 123-4), the basic neoclassical ideas on the supply of and demand for capital were provided by Rae. Fisher explicitly built on Rae, and Böhm-Bawerk, on his own acknowledgement, was fully aware of Rae's contribution. Ahmad notes an important feature of Rae's theory of capital that distinguishes it from those of Böhm-Bawerk and Fisher. The two latter are both open to the modern criticism of neoclassical capital theory of the possibility of 'reswitching'. Because of its greater simplicity, Rae's approach is not subject to this criticism.

\section{Rae and invention}

'Invention' lies at the heart of New Principles and Rae's most substantive criticism of Wealth of Nations was Smith's failure, as he saw it, to give adequate recognition to invention as the principal source of growth. Smith, according to Rae, attributed economic growth exclusively to the accumulation of capital, and this accumulation, in turn, was due to individual savings decisions. While Rae agreed that an individual could certainly become rich by saving, things were different for society as a whole. A 
society can use saving productively only by creating new capital assets and can do this only by adopting new methods of production, which have to be invented. Thus:

[i]nvention is the only power on earth that can be said to create ... Industry and parsimony increase the capital of individuals; national wealth ... cannot be increased but by the aid also of the inventive faculty.

(Rae 1834: 14-15)

Brewer (1998: 129) acknowledges Rae as the first economist to see technical change as the main source of continuing economic growth. As Rae saw no limit to the scope for invention, he was also the first to see no limit to the potential for future growth. Rae differed from Smith in regarding saving and population as both endogenous. For Rae, invention was the exogenously determined source of growth. Rae's argument was (1) that invention is needed to maintain the incentive to save; and (2) that invention has causes independent of individual savings decisions. These causes are open to influence by the 'legislator', whereas individual savings decisions are not. Brewer (1998: 130-1) identifies three elements in Rae's case for the role of invention in enabling continued saving and investment: (1) saving/investment is responsive to changes in the anticipated rate of return on instruments; (2) invention increases the rate of return, thus inducing saving and investment; (3) without intervention by the "legislator' the rate of return would be forced down and accumulation would soon stop.

The difference between Rae and Smith is perhaps at its most acute on this issue. Rae did not deny the importance of the division of labour as a source of growth. However, he did challenge Smith's view of the underlying causality. Smith attributed the division of labour primarily to the accumulation of capital. Although Smith did refer to inventions as a factor affecting the productivity of labour, he argued that it was initially the division of labour that facilitated the invention of machines. Rae reversed the causality and argued that it is the division of labour that is the result of invention. It may be argued that the fifty years between the publication of Wealth of Nations and New Principles had seen a rapid growth of industrialisation and technological development that might explain Smith's failure to give more weight to the role of invention. Be that as it may, Rae saw invention as the primary, independent, causal factor behind economic growth. The wealth of the nation depended on: (1) the state of knowledge, which is the result of past invention; (2) the effective desire of accumulation, which determines how far that knowledge is employed; and (3) the available materials, that is, the natural environment (Rae 1834: 109).

Brewer (1998: 133-5) considers that Rae's treatment of the causes of invention is rather unconvincing. His concern with political economy led 
Rae to consider invention solely as it affected the physical world but he recognised that it could be defined much more broadly to encompass literature or art. The critical role is played by the 'man of genius', the inventor or the creator. Often struggling against misfortune or ingratitude, the inventor succeeds nevertheless in bringing to fruition some new product or process. Rae offers a not wholly convincing explanation that the invention is essentially a moral choice and that the rewards therefrom are not of this world. On a more practical note, Rae provides as an example of the potency of invention: the application of steam power to the extraction of coal. Essentially, he identifies technology transfer, whether inter-industry or inter-nation, as the driving force of growth:

I believe it will be found that there is no art in existence which we may not find means to trace ... to the rudest and most simple principles, and which may not be shown to have attained perfection by continual changes from place to place, and material to material, and by encountering consequently alternating difficulties and facilities, the former developing its powers, the latter extending their field of action, and both, by helping to introduce general principles, weakening the restraining power of the tendency to servile imitation, and advancing the progress of science. This successive passage of the same arts from one country to another ... seems to be the great exciting cause of the progress of them all.

(Rae 1834: 253)

The principal means by which technology transfer could be facilitated were import substitution and the establishment of infant industries, both of which required intervention by the 'legislator'. Rae was not a crude protectionist. He urged the 'legislator' to be cautious and to assess carefully the potential benefits of protection and to support only industries that were likely to succeed. Protection could take various forms: premiums for individuals establishing new domestic manufacture, subsidies for domestic production or import duties in order to build up full-scale domestic production. Import substitution was the principal means by which Rae thought development should proceed. It both required and stimulated 'invention' but required state support to underwrite some or all of the risks associated with production in a new location. If these could be clearly identified, then the role of the 'legislator' was clear and beneficial.

\section{Rae and international trade}

From the above, it is clear why Rae was opposed to the 'fallacies of the system of free trade'. Invention required technology transfer, which, in turn, required import substitution, which, in turn, required state intervention. Although New Principles was a critique of the classical case for free 
trade, it was, as Dimand (1998: 177) notes, far more than that. It was in the context of international trade that Rae made the important distinction between private and social advantage, rejecting Smith's claim that what is prudence in a private household can scarce be folly for a great nation. Rae's researches into economic conditions in Canada in the 1820s are the source of his views on international trade. Dimand (ibid.: 179-80) cites James (1965) as the source of the claim that Rae was the anonymous author in 1825 of an article in the Canadian Review and Literary and Historical Journal which examined the experience of Britain and the Netherlands to emphasise the benefits of government encouragement of new industries using imported technology. Rae advanced what subsequently became known as the Mill test for protecting an infant industry, namely the promise of future successful competition, given factor prices, even though it would not be privately profitable at first. Rae dissented from the Torrens-Ricardo comparative cost theory of international trade. Comparative costs could change as a result of learning-by-doing or from economies of scale. In contrast to the mercantilist position, Rae held that state intervention to support infant industries should be only temporary.

Rae made his crucial statement of the gains from trade in the introduction to New Principles:

Increased facility in the exchange of utilities operates in the same manner as the progress of invention and improvement, and carries instruments to the more quickly returning orders; increased facility in the exchange of luxuries has an immediate tendency, on the contrary, to carry instruments to the more slowly returning orders.

(Rae 1834: xv)

Rae equated exchange in non-luxury goods with invention in its effect on raising the internal rate of return, carrying instruments to more quickly returning orders (or improved productivity of capital), thus creating an incentive to increase the capital stock and productive capacity. As Dimand (1998: 183) observes, this insight of Rae's carried the analysis of the gains from trade beyond the static comparative advantage analysis of Torrens and Ricardo. Rae's analysis of the dynamic gains from trade belongs to a broader and richer heritage of international trade theory than the more widely known comparative advantage. Again the difference between Rae and Smith is marked. Rae rejected Smith's claim that if the state were to fail to promote the establishment of a new industry using imported technology, the nation's capital would be just as profitably employed. There was, according to Rae, a role for the 'legislator' to stimulate invention by the introduction of new arts, particularly 'in bringing the arts of Foreign Countries to his own' (Rae 1834: xvi).

Rae's argument for the promotion of infant industries as an essential element in the development of a nation was endorsed by J. S. Mill in his 
Principles of Political Economy (1848). Robbins is emphatic that in the history of the development of the infant industry argument Rae's was the most sophisticated statement - 'if we are looking for pure excellence of intellectual analysis, the palm must clearly go to John Rae' (Robbins 1968: 113). However, it must not be thought that Rae's advocacy of the promotion of infant industries meant that he was opposed to free trade. In chapter 12 of Book II of New Principles, 'Of Exchanges between Different Communities', he was very positive about the benefits resulting from such exchanges. But he focused more on the benefits of foreign trade than on the sources of comparative advantage.

\section{Rae and conspicuous consumption}

A feature of Rae's analysis of international trade was the negative view he took of the impact of the importation of luxuries on the development process. This was a major innovation in New Principles because up till than few political economists had considered the consumption of luxuries as a matter of any real significance, particularly as the object of criticism. ${ }^{1}$ There was in New Principles a strong moralising tone against luxury consumption. Luxury was 'the expenditure occasioned by the passion of vanity' (Rae 1834: 265) and vanity he defined as:

[t]he mere desire of superiority over others ... A purely selfish feeling; its pleasures centre on the individual; and if it does not endeavour to diminish the enjoyment of others, it is never directly its object to increase them ... Its aim in all cases that concern our subject, is to have what others cannot have.

(Ibid.: 265-6)

Such vanity was satisfied only when the luxury consumption that it encouraged was 'conspicuous'. While Rae held strongly to the view that excessive conspicuous consumption was morally reprehensible, he also believed that its consequences extended into the economic sphere, leading inevitably to national economic decline. It is on this issue that Rae's strongly held Presbyterian views shine through. But his objection was more than simply moral. It is tempting to think of Rae as a precursor of Veblen on conspicuous consumption. However, as Mason (1998: 107) points out, Rae's approach was quite different. Veblen's Theory of the Leisure Class (1899) was first and foremost an attack on the evils of American finance capitalism from a quasi-socialist standpoint rather than the religious or moral perspective of Rae. Mason concludes that it is Rae's fate to have made a significant contribution to the evolution of ideas on luxury expenditure and status-seeking consumption, but to have seen his work overshadowed by Veblen's later exploration of pecuniary emulation and the formulation of tastes. On a more positive note, however, belated 
recognition is being given to Rae's unique contribution to economic thought on matters relating to conspicuous consumption (Mason 1998: 107).

\section{Rae and the Scottish political economy tradition}

So where does Rae stand in the Hall of Fame of Scottish political economists? I would like to suggest that he should appear much higher up the league table than he currently stands. The shibboleth of Scottish political economy is Smith and Wealth of Nations. I do not wish in any way to diminish Smith's great achievement or to deny the enormous influence that it has had on the evolution of economics since 1776. But others, some of whom are discussed in this volume, have also made important contributions. It has been Rae's fate that the profundity and sophistication of his contribution has been only spasmodically recognised. To what extent can Rae be considered a political economist in the Scottish tradition? Most of the other great names in the Scottish political economy tradition - Anderson, Carmichael, Chalmers, Ferguson, Hume, Hutcheson, Lauderdale, Reid, Steuart and Stewart - spent all, or the greater parts, of their lives in Scotland, occupying at some time or another, by virtue of birth or ability, positions of influence in the Scottish establishment. Rae is the exception. He left Scotland as a young man, educated as a doctor, never to return.

It is the very fact of Rae's departure from Scotland that resulted in the development of his interest in political economy. Had he not emigrated to Canada, he would never have been exposed to the influences that led him to become involved in the politics and economics of that emerging nation. Had Rae remained in Scotland what might he have achieved? It is, of course, very difficult to speculate. The political and economic conditions of early nineteenth-century Scotland were vastly different from those of Canada. This is not to say that Rae might not have turned his very considerable intellect to analysing the problems of the small, rapidly industrialising society that was Scotland at the time and still written New Principles, although perhaps a rather different volume. Who knows? He might have pursued a career as a doctor, although James records that much of the medical treatment he offered the ailing inhabitants of Hawaii appears to have been extremely crude. Rae had a great interest and competence in geology and published a number of scientific papers of considerable quality. Or he might have sought to bring some of his engineering inventions to commercial fruition.

Despite his geographical isolation from the circumstances and institutions of his native land, to what extent can Rae be considered a fully paidup member of the Scottish political economy tradition? Dow et al. (1997) discuss the idea of tradition in Scottish political economy. Tradition, they argue, connotes a passing down from one generation to another over a long period of time. The origins of the Scottish political economy 
tradition can be seen, for example, in the educational system, with its early emphasis on the historical and philosophical. A tradition arises from a particular set of institutions and persists in the continuation of the environment that originally spawned it. By this criterion, Rae is undoubtedly in the Scottish political economy tradition. Educated at Aberdeen and Edinburgh Universities, as well as in Paris (another Scottish tradition), his early years in Canada were spent as a schoolteacher in a community of expatriate Scots who were determined to ensure the survival of their Scottish religious, educational and cultural traditions. No problems here.

Dow et al. then discuss the nature of the Scottish political economy tradition and argue that it possesses a number of features originally identified by Dow (1987). From the necessarily brief discussion of New Principles presented in this chapter it should be clear that Rae satisfies a number of Dow's criteria. In particular, there is in New Principles a recognition of the sociological and psychological aspects of theory appraisal (recall that Mixter retitled New Principles as A Sociological Theory of Capital); a concern with practical issues; a preference for breadth of understanding; and a specification of first principles in terms of a non-individualistic representation of human nature, with a consequent emphasis on conventional behaviour. These are some of the more important criteria identified by Dow. No problems here, either.

But in order to establish the contemporary relevance of the Scottish tradition, Dow et al. (1997) argue that it must be possible to identify in some modern schools of thought the 'political economy' approach that characterises the Scottish tradition. Dow et al. argue that neo-Austrian economics, some Marxist economics, institutionalist economics and post-Keynesian economics all share a theory of knowledge that is concerned with understanding real open-system processes. This is what the Scottish political economists sought to do. Smith's contribution to these political economy paradigms is well documented. But Rae, too, had an important contribution to make. As reported earlier in this chapter, Mitchell (1934) identifies Rae as a founding father of institutionalist economics. We have noted Rae's influence on Böhm-Bawerk and through him on the Austrian and neo-Austrian schools. There is also a line from Rae to the Austrians via Menger. Rae and Menger had very similar definitions of instruments and goods based on the idea of human needs (Drakopoulos 1998). Each devised the concept of order which categorises instruments and goods. Although they had different purposes, Rae to build a theory of capital, technology and accumulation, Menger to build a theory of consumer behaviour, they shared the same conceptual idea of orders. To the extent that Schumpeter can be classified as belonging to the school of evolutionary economics, Rae's influence there is unmistakable. Deans and Deans (1972) assert emphatically that Schumpeter benefited directly from Rae. While there were differences between Schumpeter 
and Rae in terms of the role they attributed to the entrepreneur, they both emphasised a social philosophy regarding capital in the development process. Inventors, according to Rae, were driven by the 'social and benevolent affections of society' (Rae 1834: 208), but their activities disturbed and jarred the existing systems by which men guided their feelings and reasonings. The material rewards (profits) and praises of society were left to what Rae called the 'transmitters' (Schumpeter's 'entrepreneurs') who introduced inventions to society. Inspection of chapter 2 of Schumpeter's Theory of Economic Development (1934) on the fundamentals of development reveals many similarities to passages that occur extensively in Rae.

Finally, Mair and Laramie (1998) agree with Dow that it is quite legitimate to identify the method and content of modern post-Keynesian economics with the Scottish tradition. Gootzeit's (1998) analysis of Rae's treatment of savings shows Rae was certainly not part of the Smith-Mill-Marshall-Keynes tradition that focused on personal savings as productive. Rae was much more in the Senior-Cairns tradition that focused more on business savings as the chief force behind national expansion. Although Rae never used the term 'productive savings', his ideas implied that business savings were more productive than personal savings. Rae has a completely different approach from the mainstream on the source of savings. This, as Mair and Laramie suggest, puts Rae into the post-Keynesian strand of public finance associated with Kalecki.

\section{Conclusion}

Rae has suffered the fate of all prophets both in his native land and in the land of his adoption. As this chapter has tried to show, Rae's New Principles is a book of great originality and lasting importance. Had he produced a second edition in the 1850s, as correspondence with John Stuart Mill confirms he was considering, he might have toned down his criticisms of Smith. A second edition might also have avoided the clumsy re-editing by Mixter that undoubtedly retarded wider twentieth-century appreciation of Rae. Indeed, had it not been for the sterling work of R. W. James in organising the publication in 1965 of the original version of New Principles, Rae's name might have disappeared altogether from the history of Scottish political economy. That would have been a great loss.

\section{Notes}

This chapter is dedicated to the memory of R. Warren James, who died in November 2004. Without James's sterling efforts the name of John Rae would undoubtedly have languished in obscurity, an undeserved fate for a gifted economist.

1 Hume and Smith were exceptions, but took a more positive view of luxury consumption; see Chapter 4 in this volume on Hume. 


\section{Douglas Mair}

\section{References}

Ahmad, S. (1998) 'Rae, Böhm-Bawerk and Fisher on the supply and demand of capital', in O. F. Hamouda, C. Lee and D. Mair (eds) The Economics of John Rae, London: Routledge.

Böhm-Bawerk, E. (1959) Capital and Interest: History and Critique of Interest Theories I, South Holland, IL: Libertarian Press.

Brewer, A. (1998) 'Invention', in O. F. Hamouda, C. Lee and D. Mair (eds) The Economics of John Rae, London: Routledge.

Deans, R. H. and Deans, J. S. (1972) 'John Rae and the problems of economic development', Review of Social Economy 30: 97-111.

Dimand, R. (1998) 'Rae and international trade', in O. F. Hamouda, C. Lee and D. Mair (eds) The Economics of John Rae, London: Routledge.

Dow, A., Dow, S. and Hutton, A. (1997) 'The Scottish political economy tradition and modern economics', Scottish Journal of Political Economy 44: 368-81.

Dow, S. C. (1987) 'The Scottish political economy tradition', Scottish Journal of Political Economy 34: 335-48.

Drakopoulus, S. A. (1998) 'The concept of orders of instruments and goods in Rae and Menger', in O. F. Hamouda, C. Lee and D. Mair (eds) The Economics of John Rae, London: Routledge.

Fisher, I. (1982) The Rate of Interest, New York: Macmillan.

Gootzeit, M. J. (1998) 'Productive savings, invention, and investment supply in Rae's growth theory', in O. F. Hamouda, C. Lee and D. Mair (eds) The Economics of John Rae, London: Routledge.

Hollander, S. (1998) 'John Rae and Adam Smith', in O. F. Hamouda, C. Lee and D. Mair (eds) The Economics of John Rae, London: Routledge.

James, R. W. (1965) John Rae: Political Economist, 2 vols, Toronto: Toronto University Press.

Mair, D. and Laramie, A. J. (1998) 'Rae as an early post-Keynesian', in O. F. Hamouda, C. Lee and D. Mair (eds) The Economics of John Rae, London: Routledge.

Mason, R. (1998) 'John Rae and conspicuous consumption', in O. F. Hamouda, C. Lee and D. Mair (eds) The Economics of John Rae, London: Routledge.

Mill, J. S. (1848) Principles of Political Economy with some of their Applications in Social Philosophy, London: Longman.

Mitchell, W. C. (1934) 'The prospect of economics', in R. G. Tugwell (ed.) The Trend of Economics, New York: Knopf.

Rae, J. (1834) Statement of some new Principles on the Subject of Political Economy, exposing the Fallacies of the System of Free Trade and of some other Doctrines maintained in the 'Wealth of Nations', Boston MA: Hilliard Gray.

Robbins, L. (1968) The Theory of Economic Development, London: Macmillan.

Schumpeter, J. A. (1934) The Theory of Economic Development, Oxford: Oxford University Press.

Schumpeter, J. A. (1954) History of Economic Analysis, London: Allen \& Unwin.

Veblen, T. (1899) The Theory of the Leisure Class, New York: Macmillan. 


\title{
12 Economics in the Scottish universities from the late nineteenth century
}

\author{
Alexander Dow and Alan Hutton
}

\section{Introduction}

Late Victorian Scotland saw the economy prosper as never before. Glasgow was the second city of the British Empire, and civic pride expanded in sympathy. The universities shared in the optimism and were a vital part of the civic fabric.

Political economy emerged as a university discipline in Scotland towards the end of the nineteenth century in this atmosphere. Drawing on the inspiration of the earlier Enlightenment thinkers, especially Adam Smith, its place as a degree subject in the four Scottish universities slowly evolved, and what we, following Macfie (1955), identify as a distinctive tradition of Scottish political economy emerged in the teaching and scholarship of its practitioners.

In what follows we first outline the roots of the Scottish tradition in political economy, then examine in some detail the pedagogical references of the subject as it embedded itself in the curriculum. The next section considers the practice of the subject by looking at two leading figures, J. Shield Nicholson and William Smart. Finally in the conclusion we assess the evidence up to 1914 for the distinctiveness of the approach we identify.

\section{The roots of the Scottish political economy tradition}

The Scottish political economy tradition has its roots in the Scottish Enlightenment in the flowering of economic thinking that occurred in that era. However, it was reinvented for the purposes of education in economics in the Scottish universities from the 1870s onwards. The political economy tradition that developed did so because of a utilisation of the Enlightenment past, and its application to the situation of the current economy, as economics slowly professionalised and developed an institutional base in universities.

The economics of the Scottish Enlightenment was marked by the unified approach to knowledge to which the learned at that time might 
still aspire. The writings of Newton, the Roman Stoics and Calvin were all within the grasp of an Enlightenment thinker. In particular someone like Adam Smith was as much a moral philosopher as he was an economist (Young 1997). The moral perspective was never absent from the judgements of the Wealth of Nations. However, there was a distinct empirical edge to Enlightenment thinking. The economists of that era were inductive as well as deductive in their approach to knowledge (see Chapters 6 and 7 , this volume). They observed keenly the society around them and, from first principles based on these observations, used short chains of logic to come to the general statements of their systems. This was as true of a lesser figure such as James Anderson (Dow 2004) as it was of Adam Smith, and the other giants (Dow et al. 1997).

Yet for a time this tradition seemed to die out in Scotland. The Enlightenment ceased to flower. Economics progressed as far as Thomas Chalmers and John Ramsay McCulloch, but thereafter its influence was diverted through the Mills into English classical political economy. With the powerful influence of Ricardo, and his deductive emphasis, this was a very different discipline from the political economy of the Scottish Enlightenment.

Following the union of the Parliaments between Scotland and England in 1707 Scotland, of course, remained a separate national context (within the UK state) marked by its own history and institutions - most important for our purpose its own system of higher education (Davie 1961). The factors which led to a somewhat distinctive history for economics as a university subject in Scotland, also led to other differences in the character of the discipline north of the border. In particular, the structural breadth of the degree programme, with its early emphasis on moral philosophy and an historical approach to teaching, went hand in hand with the characteristic epistemology of the Scottish Enlightenment and of the emerging social sciences (Dow 1987).

The identification of a separate Scottish tradition in economic thought has its origins in a lecture to the re-established Scottish Economic Society by Macfie (1955). Macfie identified a 'characteristic Scottish attitude and method' to economics, describing it as 'the philosophical approach' or 'the sociological approach'. Especially 'clear and influential between roughly 1730 and 1870', it was 'still alive' and still influential in Scotland in the $1950 \mathrm{~s}$, although the 'scientific or analytical method' now dominated the discipline.

Scottish political economy includes the following characteristics (from Dow 1987):

1 Acceptance of the limitation of theory.

2 Concern with practical issues.

3 A preference for arguing from first principles.

4 A preference for the breadth of understanding achieved by drawing on a range of disciplines in an integrated way. 
5 A relatively unimportant role given to mathematics, since that language does not sit easily with an interest in historical and institutional arrangements.

6 Scottish political economists make no claims to a monopoly of truth arguments cannot be settled 'solely by virtue of the internal logic of formal theories' (Mair 1990: xiv).

In the Scottish Enlightenment the historical method had been developed as a major method of pursuing knowledge. (David Hume, after all, was known as an essayist and a historian to his contemporaries rather than as a philosopher). The Wealth of Nations is full of historical passages (Smith 1776). In looking back to the flowering of economics more than a century before in Scotland, the late nineteenth-century Scottish tradition absorbed naturally an approach to social science in which history was integral.

In what follows we give some meat to these bare bones by describing the development of tuition in political economy in the Scottish universities in the 1870-1914 period. Then we look at two of the major figures in the small group of then practising university scholars in economics J. Shield Nicholson and William Smart. In conclusion we assess the argument for a distinctive tradition in Scottish political economy in this period.

\section{Political economy in the Scottish universities}

In this section we follow the evolution of political economy in the Scottish universities up to the First World War in 1914. We argue that the nature of the university curriculum in Scotland at that time, and in particular the seminal role of moral philosophy, conditioned the evolution which occurred. We try to understand what was taught through examining the published course syllabuses and reading lists.

There are four ancient Scottish universities. They are the University of Glasgow, the University of Edinburgh, the University of St Andrews and the University of Aberdeen. An examination of the university calendars of each of those institutions provides some information on the incorporation of political economy within their curricula.

The first evidence from the calendars of a class entitled Political Economy is in the University of Edinburgh in the academic year 1864/65, though in the academic year 1865/66 a class of this name also appeared in the University of St Andrews. However, it is known that Thomas Chalmers lectured there on the subject earlier in the century, without it being advertised as such in the calendar. Later the University of Glasgow designated a class by this name in 1871/72 and the University of Aberdeen did likewise in 1872/73. In each case the department in which the class was lodged was the Department of Moral Philosophy. 
A Professor of Political Economy was appointed to the University of Edinburgh in 1871: William Hodgson. Simultaneously the subject separated from Moral Philosophy. In the University of Glasgow the first professor was appointed in 1896. However, a lectureship for Political Economy had been in place since 1892 .

At the University of Aberdeen, Political Economy disappeared from the calendar between 1877 and 1897. Only in 1902 did Political Economy reappear as a class within Moral Philosophy. A professor was appointed at the University of Aberdeen in 1921. At the University of St Andrews in the 1890s, Political Economy disappeared from the calendar, but by 1900 it had appeared in the calendar as a class with a syllabus. In that year also a lecturer was appointed to teach the syllabus, but it was not until 1947 that the first professor in Political Economy was appointed at the University of St Andrews.

What of the content? The University of Edinburgh calendar for 1866/67 states that within the Moral Philosophy department 'a separate course of lectures will be delivered at three o'clock, twice a week on Political Economy commencing after Christmas'. The textbooks to be used were J. S. Mill's Principles of Political Economy and Professor Fawcett's Manual. This class appears to have been taught for only three years, whereupon it disappeared from the calendar. By 1870 Political Economy had reappeared as a separate class within the Moral Philosophy section of the calendar. However, in 1872 the Political Economy class separated from Moral Philosophy and was replaced by a new course taught by the newly appointed Professor Hodgson. The course now on offer had three sections, one in economics, one in commerce and a third in mercantile law. In 1882/83 the calendar for the University of Edinburgh records a change in this course entitled 'Commercial and Political Economy in Mercantile Law' as the new professor, Nicholson, takes over. The calendar announces that the lectures will follow the order of arrangement of J. S. Mill in his Principles of Political Economy. It is noted that reference will also be made to Adam Smith, Ricardo, Giffin, Cliffe Leslie, Walker, Jevons, Marshall and Bagehot. The contents of this course remained more or less the same until 1900 .

By 1900 the course had added readings, including Marshall's Economics of Industry and two works by Professor Nicholson himself. In 1908 the name of the course changes to Political Economy with, however, the syllabus remaining exactly the same and with Professor Nicholson still teaching the material. The calendar of 1909/10 notes that the honours class will have a course 'devoted to more difficult economic theories not taken up in the ordinary class and partly to the special treatment of economic progress, economic functions of government, and public finance'. In 1909 a class in Statistics and Mathematical Economics is added with twenty-five lectures, which count for half a course in the honours examination. The recommended text is M. Bowley, Elements of Statistics. Instructions suggest 
'a mathematical treatment both by geometric and algebraic methods of questions of utility, demand and supply, production, monopolies, taxation, trade etc.... [R] eferences will be given to the treatment of mathematical economics by Cournot, Pareto, Edgworth, Walras, Marshall and others.' The half-course was taught by a lecturer, G. A. Carse, not Professor Nicholson.

In 1921 a new course is added called Realistic Economics, and students are required to take the ordinary course in Political Economy before taking this particular class. The introduction states, 'the lectures will be devoted to the realistic treatment of economic problems of present-day importance and the subjects dealt with will be selected from the following' - the list includes transport, industrial remuneration, unemployment and the distribution of national income.

At the University of Glasgow, it has already been noted, a class in Political Economy existed within the Moral Philosophy section in 1871. However, the calendar for $1887 / 88$ sheds some light on its teaching. It is noted that:

the class of political economy has usually been held every second year alternating with the higher moral philosophy class; but during next session both classes will be taught ... in the Political Economy class, $\mathrm{Mr}$ William Smart [Assistant to Professor Caird in Moral Philosophy] will lecture upon the laws of production and distribution of wealth, with special reference to the freedom of trade, the land system, socialism, etc.

(University of Glasgow Calendar 1887/88)

By 1893 a new degree in Political Economy has been formed. In 1892 a separate lectureship had been instituted by the university, to which William Smart was appointed, later to become the first professor. The lectures were described in the calendar as 'partly doctrinal, partly historical and cover[ing] the general principles of economics'. The textbooks were Marshall's Elements of Economics of Industry, supplemented by Gide's Political Economy and the first six chapters of Ricardo's Principles.

The calendar of 1888/89 notes as follows:

The [Adam Smith] Chair of Political Economy was founded by ordnance number 149 of the Universities Commission (1889) of date 25 February, 1896, with an endowment of $£ 15,000$ sterling given by $\mathrm{Mr}$ Andrew Stewart, Merchant, of Glasgow.... Before the founding of the Chair, Political Economy was attached to the Chair of Moral Philosophy till 1892, when a separate lectureship was instituted by the University.

The main textbook has now become Alfred Marshall's Principles of Economics. The syllabus is concerned with demand and consumption, but also 
with the theory of the state from Aristotle, and some disputed questions on the theory of money, taxation and public finance. A small subsidiary course entitled 'Social Economics' is introduced in 1908; the syllabus for this course includes 'the History and Causes of Pauperism and Unemployment. . . in the light of the evidence and reports of the Poor Law Commission 1909'. An Economic History course was added in 1910.

The honours Economic Science degree was more specialised. The books used include Marshall's Principles, Bastable's Public Finance, Seligman's Essays in Taxation, Ingram's History of Political Economy, Nicholson's Money and Monetary Problems, Warner's Landmarks of English Industrial History, Cannan's Theories of Production and Distribution, the report of the Royal Commission on the Poor Laws, Adam Smith's Wealth of Nations, and Memoranda on Classification and Incidence of Imperial and Local Taxes. (The calendar of the University of Glasgow for 1938/39 reveals little had changed by then in the syllabus.)

The University of St Andrews calendar for 1865/66, which is the first calendar available, reveals within the Moral Philosophy section of the Faculty of Arts a small course on Political Economy. This consists of two lectures a week and the textbook is Senior's Political Economy. In the 1873/74 calendar the textbook becomes John Stuart Mill's Principles of Political Economy. In 1877/78 the textbook changes to Fawcett's Manual of Political Economy, and in 1885 the textbook changes again to Cossa's History of Political Economy. ${ }^{1}$ Once again in 1886 the textbook changes to Walker's Brief Textbook of Political Economy. In 1893 this class in Political Economy disappears from the calendar.

The St Andrews University calendar for 1900/01 records as follows:

A lecturer in Political Economy is appointed by the University Court ... [A] course of 100 lectures will be given to the ordinary class during the winter session ... [T] hese will deal with the theory of economics exemplified by reference to modern industrial conditions. As far as possible the subject will be illustrated in its statistical aspects by curves and other diagrams.

The lecturer was William R. Scott (who, from 1915, became Professor of Political Economy at Glasgow University). His 1900/01 appointment marks the divorce of Political Economy in St Andrews from Moral Philosophy as a subject. Books mentioned for this course include Marshall's Principles of Economics, Nicholson's Principles of Political Economy and Walker's Brief Text of Political Economy. Students are recommended to read Jevons's Primer of Political Economy before joining the class.

By 1911 a course appears entitled 'Honours in Economic Science'. The calendar notes the requirement: 'A more thorough knowledge of the principles of economics than that required for the ordinary degree'. Textbooks recommended are Marshall's Principles of Economics, Nicholson's 
Principles of Political Economy, Bastable's Public Finance, Boley's Elements of Statistics and Pantaleoni's Pure Economics, along with Cunningham's Growth of English Industry and Commerce. In the following year there was added J. N. Keynes's Scope and Method of Political Economy and works by Ely, Gide and Pierson. Note that there is an advanced honours class in which instruction will be given in Methods of Economics Research'. The calendar for 1921/22 notes that the title of the course has changed from Political Economy to Economics at the ordinary level and from Economic Science to Economics at the Honours level. Books previously listed are still employed, but so is Sidgewick's Principles of Political Economy and Smith's Wealth of Nations Book 5. Cameron Morrison is now the lecturer responsible for this programme.

The University of Aberdeen calendar of 1872/73 was the first to mention Political Economy. A class called 'Moral Philosophy and Political Economy' is taught by Professor Martin, but political economy seems relatively unimportant. The name of this class is changed to Moral Philosophy by 1875. In 1897/98 a course in Agricultural Economics appears in the Agriculture section. No textbooks are mentioned.

In the Aberdeen University calendar of 1902/03, Political Economy is mentioned as an additional class, still within the overall remit of Moral Philosophy. The calendar identifies D. H. MacGregor as lecturer to the class in Political Economy, giving a course of thirty lectures, together with tutorial instructions, delivered in the summer session. By 1905 the lecturer is named as Stanley Turner and recommended books include Marshall's Principle of Economics and Economics of Industry, Smart's Distribution of Income, Gide's Principles of Political Economy and Bastable's Theory of International Trade.

In the calendar of 1922 a new course is noted, 'The Organisation of Industry and Commerce'. Books for this course are S. J. Chapman's Work and Wages, W. J. Ashley's British Industries, H. Withers's Stocks and Shares, Emery's Stock and Produce Exchanges, Marshall's Industry and Trade and Fisk's International Commercial Policies.

\section{The practice of political economy in Scotland}

In the previous section we drew an outline of political economy in the Scottish universities up to World War I through an examination of what was offered to undergraduates. Now we go on to fill in some detail by an examination of the work of the two leading political economists in the Scottish universities in this period, Nicholson at Edinburgh and Smart in Glasgow.

Just over a century ago, the English historical school of economics argued strenuously for an economics to which history was entirely integral. Their impact was considerable (Koot 1987). The names commonly associated with this school are Cliffe Lesley, John Kells Ingram (both 
Irish), Arnold Toynbee, L. L. Price, William Ashley, W. A. S. Hewins and William Cunningham. In Scotland, J. Shield Nicholson and William Smart were both sympathetic to the historical approach to economics. In this they were quite characteristic of the Scottish tradition in political economy (Dow et al. 1997). Both Nicholson and Smart were also users of economic theory. They saw no contradiction between the abstract and the historical approach to economics. ${ }^{2}$

The period was marked in England by a fierce struggle waged between the incipient neoclassical approach to economics, as characterised by William Jevons and Alfred Marshall, and the English historical school. The impact of the latter lay in the creation, fully fledged by the 1920s, of the separate discipline of economic history. Marshall was influential in establishing the neoclassical school in economics, with marginal analysis and the concept of equilibrium as core notions, but he also acknowledged the proposition of the historical economists that economic theory and policy must be relevant to a particular time and place (Hodgson 2001). Thus economic studies in England came from 1900 onwards to have the three aspects - theory, applied studies and history. But theory emerged as the dominant aspect, and the one which would become central to an ever more abstract economics as the twentieth century advanced.

The argument is that in Scotland the separation of theory from history and philosophical investigation did not fully occur until much later. The Scottish approach, which we call Scottish political economy, gave much less weight to deductive theory than the neoclassicals did, rather pursuing in teaching and scholarship an applied orientation in which historical, philosophical and doctrinal elements remained integral. The context and character of this Scottish applied economics, which persisted until the 1950 s, are considered more fully in the next chapter.

J. Shield Nicholson was appointed Professor of Economics in the University of Edinburgh in 1880 and subsequently married the daughter of his predecessor, Professor William Hodgson, in 1885. (The two men never met, but Nicholson paid his deceased predecessor a warm tribute in an inaugural address in 1881.) Nicholson wrote textbooks, monographs, articles and novels. He was also author, in 1914, of The Life and Genius of Ariosto, an Italian Renaissance poet. Throughout his long tenure in the Edinburgh chair he published continuously. His textbook Principles of Political Economy, published in three volumes between 1893 and 1901, was a rival to Marshall's Principles of Economics.

Nicholson was a member of the UK economics establishment. Originally from Lincolnshire, he was educated in the University of Edinburgh and the University of Cambridge, where he was an early student of Alfred Marshall (Groenewegen 1995: 754). Marshall cites him in the Principles of Economics on several occasions. He was an elector for the famous appointment of Alfred Marshall's successor, when Pigou was awarded the vacant Chair (though Nicholson favoured Foxwell, and was angry at Marshall's 
support for Pigou) (ibid.: 624). Like Foxwell, Nicholson was not a disciple of Marshall. He did not adopt a marginalist approach and was critical of the concept of consumer surplus (Maloney 1991: 77-80).

Born and educated in the west of Scotland, with an interrupted period of study at the University of Glasgow, William Smart was a businessman associated with the Paisley thread-making industry before he became an economist. This experience gave him an interest in the particular aspects of any question, which he balanced in the course of his career by taking a close interest in the Austrian school of economics, a heavily deductive approach to the subject. He was aware of these twin influences, remarking as follows:

But my pleasant task of late years, in presenting to English readers the work of the Austrian school, has made me entirely a convert to its fundamental doctrine that the theory of Value is the beginning of economic science, and compelled me to revise all my conclusions in the searching light of that theory.

(Smart 1895: x)

He continued to speculate that this influence had been good 'for one who is, naturally and by education, too apt to lose himself in the fallacy of the particular instance'. Smart held the Chair in Economics at the University of Glasgow from 1896 to his death in 1915.

His intellectual influences, prior to the Austrian writers, were John Ruskin (whose ideas he actively promoted in Glasgow) and Edward Caird, Professor of Moral Philosophy at the University of Glasgow, and his mentor in joining there as an Assistant in 1892 (having lectured previously at the associated Queen Margaret's College from 1886). He translated into English, and edited, two works of Böhm-Bawerk, and he had translated, and edited, von Wieser's Natural Value. He was an influential member of the Royal Commission on the Poor Law which reported in 1909, drafting some important sections, including the chapter on a social insurance scheme, which was implemented by Lloyd George in 1911 (Jones 1916: xlvi). In this he was an important progenitor of the welfare state in Britain.

These two men were seminal in the emergence of a Scottish political economy drawing on the tradition of the Scottish Enlightenment, and referring in particular to the inspiration of Adam Smith. Along with the particular environment provided by the distinctive Scottish system of higher education, their influence forged a style which was evident in Scottish economics until the second half of the twentieth century. This was the approach which Macfie, Professor in the Department of Political Economy of the University of Glasgow, described in 1955 (Macfie 1955).

One common element which stands out is the admixture of the historical and the analytical, without dilution of the claims to scientific 
understanding. In his Elements of Political Economy (second edition, 1909), Nicholson has a short introductory section on methodology. ${ }^{3}$ In it he defines the subject succinctly: 'Political Economy, then, may be defined as the science which investigates the nature and the causes of the wealth of nations' (ibid.: 8). The debt to Adam Smith is obvious. He accepts that economists need to specialise:

At the same time it is, no doubt, often desirable to illustrate the theory by reference to actual or historical examples that in themselves are interesting and important; although on the other hand, in certain parts it is better to show the abstract nature of the treatment by an avowed use of hypothetical examples.

(Ibid.: 5)

In short, deductive methods are better in some areas, like value theory, but inductive methods are better in others, such as the causes of labour efficiency. An applied economics, using theory and adopting an historical perspective, was without methodological contradiction.

Smart was likewise relaxed in his using, as necessary, both historical and theoretical methods. He was in no doubt about the importance of history in his work. Writing about the Poor Law Commission, he states: 'I discovered in short, that to form any adequate judgement of the phenomena with which the Poor Laws directly deal, it was necessary first to know the history of the working world at the time' (Smart 1910: vii). In commenting on his two-volume Economic Annals of the Nineteenth Century, which covers 1801-20 and 1821-30, Smart, aware of his passing years, observes: 'it seemed to me that what Political Economy most wants today is just this history' (ibid.: vii).

A strong interest in practical matters, and in policy responses to economic problems, is another characteristic of Scottish political economy. Both Nicholson and Smart were devoted to this approach:

Apart from his work in presenting the Austrian approach to an English-speaking audience Smart's only other theoretical work on the Distribution of Income has a distinctly 'applied' feel to it and is ultimately concerned to wrestle with the issue of justice in the distribution. In a hard working professional life, in addition to his teaching, Smart engaged through articles, books and pamphlets in the major economic issues of the day, including bi-metalism, trade protection, local government finance, housing and wages. As a member of the Poor Law Commission ... he was a leading contributor both to its research and to the drafting of its majority report. He served on a wide range of bodies concerned with progressive social causes, especially in the West of Scotland. In the last years of his life he contributed regular, signed articles to the Glasgow Herald and Scotsman on economic issues. 
Nicholson had no less of a practical orientation. He sent the proofs of his Principles of Political Economy to J. N. Keynes for comment. In his diary for 28 March 1900 Keynes made this judgement:

I have today finished Nicholson's proof sheets. He is interesting throughout, though not profound. I think he really intends to write for the practical man, and for this end his work is admirable. He avoids the refinements and subtleties of Marshall and Sidgwick, and it is these refinements and subtleties that the practical man hates.

(Maloney 1991: 77)

Much of Nicholson's attention was devoted to what would now be called macroeconomic policy. In War Finance (a collection of articles prefaced by a dedication to his only son, killed in the Royal Flying Corps in 1917) he wrote of the war and paper money, of British credit and war finance, of the influence of demand on food prices, of labour and the war, of the food shortage and much more of a policy sort (Nicholson 1917). These articles were first published in The Scotsman newspaper. There are also articles published in scholarly journals on everything from the gold standard and inflation to John Law (a review of a book published in Italian) and the trading situation in the aftermath of the Napoleonic wars.

Moral philosophy had a special place in the system of higher education in nineteenth-century Scotland, and while political economy broke away from its embrace in an organisational context (as described in the first section of this chapter), the new discipline in Scottish universities remained strongly influenced by its roots. For instance, students taking a degree in political economy/economics in Scotland would generally also undertake a one-year course (usually taking a third of the planned work load in what was essentially a one-year modular system) in philosophy. Curricular breadth was respected as a desirable feature of undergraduate education. ${ }^{4}$

An ethical perspective came readily to the fore:

William Smart, a pupil of Caird, taught in a similar vein. To him, wealth had responsibilities as well as rights: like Caird he was concerned about social conditions, living standards and the exploitation of women workers: for him, the economist should be concerned about supplying some answers to these issues. Their larger view of the past gave them a greater sense of the complexities of the present.

(McCaffrey 1998)

Nicholson declared a preference for positive economics: 'The main business of the economist is to describe, classify and analyse a certain order of social facts, and political economy is treated as a positive science' 
(Nicholson 2001: 428). Yet this sentence introduces a chapter devoted to Christianity and economics, which Nicholson explicitly recognises as not positive analysis. Earlier his ethical concern was clear in his inaugural lecture:

I wish simply to insist on the fact that every science, old and new alike, must show, in Bacon's language, that it works for 'the relief of man's estate', that the divine gift of reason is employed for the use and benefit of mankind. By the use and benefit he did not mean the promotion of purely material interests.

(Nicholson 1881: 6)

So with respect to the analytical role given to history, the applied focus of their economic concerns and the ethical perspective taken, both Nicholson and Smart exhibit characteristics which validate their being regarded as practitioners of Scottish political economy. Add the profound respect accorded to Adam Smith as the father of political economy, and their moulding influence can be seen on those who followed, such as Alexander Gray, William Scott and Alec Cairncross. This was the style employed by those leading the profession, teaching and pursuing scholarship in Scottish economics for three-quarters of a century.

\section{Conclusion}

Scottish political economy was a tradition, or a style, forged in the creation of departments and degree programmes associated with the professionalisation of economics that took place in Scotland in the period 1870-1914. Macfie drew attention to this style in 1955 (Macfie 1955). When, over thirty years later, Dow (1987) returned to the theme of 'the Scottish Political Economy Tradition' the dominance of the 'neoclassical' analytical approach throughout Western economics was virtually complete. Douglas Mair also identified a unique Scottish political economy tradition based on philosophy, history and law (Mair 1990).

Was this style in fact different from classical political economy? One criticism of the identification of a Scottish tradition is that the era for economics until 1950 was everywhere one in which analytical exclusiveness had yet to triumph. To what can one point to show that the political economy of Scotland in the period 1870-1920 was in fact distinctive, rather than simply sharing with the study of economics elsewhere a relative absence of formalism?

The evidence comes in part from the recommended undergraduate readings. History of Economic Thought was a distinctive feature of all the programmes examined. This reflects, along with the association with economic history, the belief that history matters, and matters not just in itself but as an essential part of the understanding of complex economic issues. 
The curricula too of the universities all had a link with philosophy or moral philosophy. Most of the students undertaking the study of political economy in Scotland in this period also had to undertake the study of a unit of Philosophy. The notion of breadth has been very deeply ingrained in the idea of higher education in Scotland (Anderson 1983). The fact is that the professionalisation of economics in Scotland led, even at honours level, to less specialisation of a narrow sort than it did, let us say, generally in England.

Finally one can see an orientation towards practical affairs in the way courses were embroidered and developed - for example, the elaboration in 1921 of a course called Realistic Economics at the University of Edinburgh. Other traditions, for example the Oxford tradition of political economy, had this focus on practical affairs, but they did not have the same attachment to moral philosophy, nor did they quite have the determined attachment to the study of history which has been described above as integral to the political economy tradition in Scotland (Young and Lee 1993). Moreover in Scotland the attachment to history was not seen as antithetical to doctrinal or theoretical interests. In this sense the use of history was analytical.

An examination of the two dominant figures in this new university discipline in Scotland gives insight to the approach. The Scottish political economy tradition was not unique; it is not in dispute that elsewhere there were also approaches to economic studies in which formal methods were not exclusive and pervasive. What we see in the work of Nicholson and Smart and their colleagues, however, is a distinct national tradition, culturally and institutionally embedded in ways which would help sustain its influence in Scotland well beyond the end of the period examined here.

\section{Notes}

1 We consider this to be a reference to Cossa (1880) but note the discrepancy in the title.

2 For a somewhat contrary view of Nicholson's position re 'historicism', see Moore (2000).

3 The Elements of Political Economy was a one-volume adaptation of the earlier threevolume work, Principles of Political Economy (Nicholson 1893, 1897, 1901).

4 A debate has gone on since the 1960s in Scottish history on how far the Scottish universities narrowed, and anglicised, the university curriculum from 1889, when Parliament established a commission to report on the Scottish universities. See Davie $(1961,1986)$. For a brief assessment of the thesis see Devine (1999: 408-9).

\section{References}

Anderson, R. D. (1983) Education and Opportunity in Victorian Scotland: Schools and Universities, Oxford: Clarendon Press.

Ashley, W. J. (1903) British Industries: a Series of General Reviews for Business Men and Students, London: Longmans. 
Bastable, C. F. (1892) Public Finance, London: Macmillan.

- (1900) The Theory of International Trade, London: Macmillan.

Bowley, A. L. (1901) Elements of Statistics, London: King.

Cannan, E. (1893) A History of the Theories of Production and Distribution in English Political Economy, 1776-1848, London: Percival.

Chapman, S. J. (1904) Work and Wages [a continuation of Lord Brassey's Work and Wages], London: Longmans.

Cossa, Luigi (1880) Guide to the Study of Political Economy, London: Macmillan.

Cunningham, W. (1882) The Growth of English Industry and Commerce, Cambridge: Cambridge University Press.

Davie, G. E. (1961) The Democratic Intellect: Scotland and her Universities in the Nineteenth Century, Edinburgh: University Press.

(1986) The Crisis of the Democratic Intellect, Edinburgh: Polygon.

Devine, T. M. (1999) The Scottish Nation, 1700-2000, London: Penguin.

Dow, S. C. (1987) 'The Scottish Political Economy Tradition', Scottish Journal of Political Economy 34, 4: 335-48.

Dow, A. (2004) 'James Anderson', in D. Rutherford (ed.), Biographical Dictionary of British Economists, Bristol: Thoemmes Press.

Dow, A., Dow, S. C. and Hutton, A. (1997) 'The Scottish Political Economy Tradition and Modern Economics' Scottish Journal of Political Economy 44, 4: 368-83.

Emery, H. C. (1896) Speculation on the Stock and Produce Exchanges of the United States, New York.

Fawcett, H. (1863) Manual of Political Economy, Cambridge.

Fisk, G. M. (1907) International Commercial Policies, with special reference to the United States, New York.

Gide, Charles (1913) Political Economy: an Authorised Translation of Cours d'économie politique, Boston MA: Heath.

Groenewegen, P. (1995) A Soaring Eagle: Alfred Marshall, 1842-1924, Cheltenham: Edward Elgar.

Hodgson, G. M. (2001) How Economics forgot History, London: Routledge.

Hutton, A. (2004) 'William Smart', in D. Rutherford (ed.), Biographical Dictionary of British Economists, Bristol: Thoemmes Press.

Ingram, J. K. (1888) History of Political Economy, London: Black.

Jevons, W. S. (1881) Political Economy [Primer of Political Economy], 3rd edn, London: Macmillan.

Jones, J. H. (1916) 'Biographical Sketch', in William Smart, Second Thoughts of an Economist, London: Macmillan.

Keynes, J. N. (1890) The Scope and Method of Political Economy, London: Macmillan.

Koot, G. M. (1987) English Historical Economics, 1870-1920: the Rise of Economic History and Neomercantilism, Cambridge: Cambridge University Press.

Macfie, A. (1955) 'The Scottish Tradition in Economic Thought', Scottish Journal of Political Economy 2, 2: 81-103.

Mair, D. P. (1990) The Scottish Contribution to Modern Economic Thought, Aberdeen: Aberdeen University Press.

Maloney, J. (1991) The Professionalization of Economics, London: Transaction.

Marshall, A. ([1890] 1961) Principles of Economics, London: Macmillan.

— (1892) Elements of the Economics of Industry, London: Macmillan.

— [and Marshall, M. P] (1879) The Economics of Industry, London: Macmillan.

McCaffrey, J. F. (1998) Scotland in the Nineteenth Century, London: Macmillan. 
Mill, J. S. (1848) Principles of Political Economy, London: Parker.

Moore, G. (2000) 'Nicholson versus Ingram on the History of Political Economy and a Charge of Plagiarism', Journal of the History of Economic Thought 22, 4: 433-60.

Nicholson, J. S. (1881) 'Political Economy as a Branch of Education', inaugural address, University of Edinburgh [National Library of Scotland].

- (1888) A Treatise on Money and Essays on Present Monetary Problems, London. - Principles of Political Economy, vol. I 1893, vol. II 1897, vol. III 2001, London: Black.

- (1903) Elements of Political Economy, London: Adam and Charles Black (2nd edn1909).

(1914) The Life and Genius of Ariosto, London.

(1917) War Finance, London: King.

Pantaleoni, Matteo (1898) Pure Economics, London.

Ricardo, David (1817) Principles of Political Economy and Taxation, London: Murray.

Royal Commission on the Poor Laws and Relief of Distress (1909) Report, London: HMSO.

Seligman, E. R. A. (1895) Essays in Taxation, New York: Macmillan.

Senior, N. W. (1863) Political Economy, London: Griffin.

Sidgwick, H. (1883) The Principles of Political Economy, London: Macmillan.

Smart, W. (1895) Studies in Economics, London: Macmillan. (1899) The Distribution of Income, London: Macmillan.

- (1910, 1917) Economic Annals of the Nineteenth Century I, 1801-1820, II, 1821-1830, London: Macmillan.

- (1916) Second Thoughts of an Economist, London: Macmillan.

Smith, Adam ([1776] 1979) An Inquiry into the Nature and Causes of the Wealth of Nations, Oxford: Oxford University Press.

Walker, F. A. (1885) A Brief Textbook of Political Economy, London.

Warner, G. T. ([1899] 1930) Landmarks in English Industrial History, Glasgow: Blackie.

von Wieser, F. (1893) Natural Value, London: Macmillan.

Withers, H. (1910) Stocks and Shares, London.

Young, J. T. (1997) Economics as a Moral Science: the Political Economy of Adam Smith, Cheltenham: Edward Elgar.

Young, W. and Lee, F. S. (1993) Oxford Economics and Oxford Economists, London: Macmillan. 


\title{
13 A Scottish tradition of applied economics in the twentieth century $^{1}$
}

\author{
Alan Hutton
}

This chapter offers an account of the evolution of economics as an academic subject in Scotland from the First World War up to the 1950s. It is argued that, throughout that period at least, economic studies in the Scottish universities were marked by the influence of a long-standing Scottish political economy tradition, the nature of which was outlined in the previous chapter. The impact of that tradition, both on the university economics curriculum and on the scholarly work of university economists, can be seen in a characteristic emphasis on applied, historical and philosophical aspects. By the end of the 1950s, however, that Scottish tradition had been largely displaced in the process of internationalisation of the modern American mainstream approach with its emphasis on abstract deductive theory, mathematical modelling and econometrics.

In the early years of the twentieth century economic studies could be seen as comprising three important elements: theoretical, applied and historical. Of these, most significantly under Marshall's influence, 'economic theory' had assumed the primacy. Applied economics, seen as either the application of economic theory to economic problems and policies or as inductive empirical work in economics, had an important but subsidiary position, and, with the eclipse of the English historical school, economic history was in the process of being exiled as a separate discipline. For a subject with a recognisable history of almost a hundred years, however, political economy, or economics, as it was now increasingly frequently known, had taken a long time to become established as an autonomous university discipline in Britain. Indeed, Kadish and Tribe (1993: 3) suggest that 'economic science did not become firmly rooted in the academic curriculum of the modern English university until after the First World War'. They go on to assert that in Scotland such a development did not fully take place until after 1920 (ibid.: 16). It is argued below that this difference in timing is complemented by a difference in approach in Scottish economic studies and that the differences share common roots.

Following a brief review of the Scottish political economy tradition and of some of the factors that might explain its continuing influence in Scot- 
land after the First World War, the remainder of this chapter offers an examination of the organisation and outputs of teaching, research and scholarship in economics in Scotland up to the 1950s. The story that emerges is of a tradition of applied political economy, characteristically Scottish and supported by distinct Scottish traditions and institutions, which ultimately declines in the face of the spreading hegemony of modern formal analytical economics.

\section{The Scottish political economy tradition revisited}

The notion of a Scottish political economy tradition, a characteristic method and attitude, originating with Macfie (1955) and developed by S. Dow (1987) and Mair (1990), was introduced in Chapter 1 and is further developed in Chapter 12. That tradition starts with concern about practical problems, and recognises both the limitations of deductive economic theory and the value of the breadth of understanding provided by an integration of different disciplinary approaches, including the systematic use of history. In practice this amounts to a different kind of 'applied economics' from those of the two conventional definitions referred to above. Here the whole purpose of economics is 'application', the mode of theory employed is influenced by empirical observations and by the nature of the policy issues addressed, and theory must be judged by its ability to inform policy, that is, to be mapped on to reality.

The value of the general idea of a 'tradition', and of a particular 'Scottish political economy tradition', for the interpretation of the history of economics in Scotland has been argued more fully elsewhere (Dow et al. $1997,1998)$. Such a 'tradition' might include 'not simply theoretical, practical and descriptive principles, but the role and organisation of teaching ... the application of economic knowledge and the establishment of professional and academic associations' (Tribe 1988: 3 n. 6). Traditions evolve through their interaction with their institutional environment. As was argued in Chapter 12 above, a tradition of economic thought and practice is a product of the wider intellectual, social and economic circumstances within which they exist. It will both influence and be influenced by institutional evolution within both the economics community and the wider society, and the continuity of its influence will be related to the persistence of important features of the institutional environment in which it arose.

Several factors can be seen to contribute to the tradition of applied political economy which characterised much of economics in Scotland in the first half of the twentieth century. Whilst its longer-term roots are discussed in Chapter 12 above, it is worth re-emphasising here the importance of key features of the Scottish university system, in particular the wider access to higher education and the breadth and philosophical roots of an undergraduate curriculum which, nevertheless, provided an 
educational basis for a more extensive range of professional and business employment than was typical in England (Anderson 1992). Even after the introduction of honours programmes the pattern remained much broader and less specialised than south of the border - a factor which must help explain Kadish and Tribe's conclusion that economics was much slower to establish itself as an autonomous discipline in the Scottish universities. Whilst an introduction to political economy had formed a part of the education of significant numbers of Scottish students from the mid-nineteenth century - many of whom were part-time and nongraduating - even in the inter-war period the size of honours classes in economics remained comparatively small.

If, as Robinson and Eatwell (1973: 2) assert, 'economics has three (interrelated) aspects or functions - to try to understand how an economy operates, to make proposals for improving it, and to justify the criterion by which improvement is judged', then the approach taken to understanding economic society will influence the form of economists' contribution to its improvement - 'applied economics'. The linked purposes of understanding the world and attempting to improve it are inseparable in the Scottish political economy tradition ${ }^{2}$ and, from the characteristics highlighted above, we might expect that economists in Scotland would be particularly likely to take an interest in economic and social problems and policy issues and, as practitioners of applied economics, would adopt approaches which viewed:

the historical background to economic problems as at least as significant as anything contributed by mathematical analysis and [take] for granted that economic forces had to be studied in their social and political context and with due regard to psychological factors.

(Cairncross 1996: 141)

In what follows, the argument that an applied political economy in a particular Scottish tradition characterised economic studies in Scotland up to the 1950s is tested against a range of evidence.

\section{Economics in Scotland from the First World War to the 1950s}

An examination of aspects of economics in Scotland in the twentieth century will cast further light on the proposition that practice there - in a way that stemmed, at least in part, from the influence of a Scottish political economy tradition with its central purpose of social improvement was characterised by an emphasis on applied work of a particular kind. Scotland was not, of course, isolated from the development of work in economics in England and elsewhere. But if the kinds of economics taught and practised up to the 1950 s were influenced by general trends and 
developments in the discipline, and by Scotland's position in the wider world of the discipline, we must also consider in what ways the impact of such influences was tempered by Scottish national traditions, which may have affected both those elements of the economics of the day which were influential in Scotland and, more generally, the role given to economics and economists within and outwith the universities. In what follows we consider a number of aspects of economics teaching, scholarship and research in the Scottish universities, as well as the wider organisation of the profession in Scotland.

\section{Economics in the Ancient Universities}

Distinctive elements in the economic studies in the two leading Scottish institutions had already emerged before the First World War. In the previous chapter it was demonstrated that the work of the two leading figures in Scottish university political economy before the First World War, Nicholson in Edinburgh and Smart in Glasgow, was, in various respects, both within the Scottish tradition and, in modern terms, 'heterodox'. In fact Koot (1987: 155) places Nicholson's writings 'within the tradition of historical economics', and certainly, in the introductory sections of his three-volume Principles of Political Economy (1897), Nicholson gives importance to theory, applied work and history, and, accordingly, to an eclectic range of methods encompassing the deductive, inductive and the historical. This approach he places clearly in the tradition of Adam Smith. When Hewins, having been selected by the Webbs because of a shared 'dislike of the so-called Manchester school' and a 'common faith in the practicality and urgent necessity of a concrete science of society implemented through historical research, personal observation and statistical verification' (Koot 1987: 171), began to organise the curriculum of economic studies at the newly established London School of Economics in 1895, he sought support for the project from those opposed to orthodoxy. In response Smart wrote from Glasgow that it realises what I have mapped out for my own place here' (ibid.).

Guillebaud (1954a:12) distinguishes three main categories in the teaching of economics:

1 Teaching economics as part of a general education.

2 Teaching economics as part of the educational preparation for professional careers, including business.

3 Training those who regard economics as their main subject of study (and who may go on to work as 'economists').

If the institutionalisation of economics as a university subject implies the development of provision in category 3 then it is not clear that economics was fully established in the Scottish universities until after 
1945. As we suggest above, political economy teaching as part of a general education and as part of professional preparation was instigated in all four Scottish institutions in the nineteenth century.

The provenance of the Chairs which were set up in Edinburgh and Glasgow reflects a particular link with commerce. The Edinburgh Chair, founded in 1870 and named the 'Chair of Commercial and Political Economy and Mercantile Law', ${ }^{3}$ was endowed by the Merchant Company of Edinburgh in effect for the commercial education of those involved in commerce and law (Rankin 1955). The Adam Smith Chair in Glasgow followed in $1896^{4}$ with an endowment from a Glasgow ironmaster (Macfie 1952). By the 1950s each of these Chairs had had only three incumbents. ${ }^{5}$ Chairs in political economy were established in Aberdeen in $1921,{ }^{6}$ and in St Andrews, where a lectureship had been created in 1900, in $1947 .{ }^{7}$ Honours classes had been established only in 1898 in Glasgow, 1900 in Edinburgh and Aberdeen and rather later in St Andrews, and throughout the period it was not possible to take 'single honours' in political economy at Glasgow.

Right up to the late 1950 s staff numbers remained low. In Glasgow prior to 1914 the professor was joined by two assistants ${ }^{8}$ (one in Social Economics and one in Economic History), the number rose to four by the 1930s (Cunnison, Buyers, Nisbet and Macfie) and in 1936 to five when (later Sir) Alec Cairncross returned from Cambridge as lecturer. By the early 1950s there were three lecturers and one assistant in Political Economy, two in Social Economics and two in Economic History.

In Edinburgh prior to 1914 Professor Nicholson was assisted by a lecturer in Economic History and a lecturer in Statistics and Mathematical Economics. The number of lecturers rose to three in the 1920s and to six by the mid-1950s. The total number of university teachers of economics (including economic history and statistics) in Scotland in 1954 was only twenty-eight (Guillebaud 1954b: 221). Whilst the number of honours graduates in Economics at Edinburgh over the period 1902 to 1925 totalled only seventy-three and even, in the late $1950 \mathrm{~s}$, was less than ten per year, those taking the ordinary Political Economy class rose from 267 in 1921 to around 400 in the heyday of Sir Alexander Gray in 1949 (Rutherford 1997).

The Edinburgh honours Economics curriculum from 1910 until the late 1950s was made up of Political Economy (three papers); Economic History (three papers); Political Science (one paper) and one of (a) Statistics and Mathematical Economics, (b) Economic Geography and (c) Mercantile Law. As with Glasgow, Political Economy always featured History of Economic Thought and Social (or Realistic) Economics. Edinburgh was, however, distinctive in the establishment (with the strong support of Nicholson) in 1920 of a separate Department of Commerce with Chairs in Organisation of Industry and Commerce and Accounting and Business Methods. The B.Com. degree, which included the Political 
Economy ordinary course and two optional Economics half-courses had over twenty graduates annually by 1923. In Glasgow an 'Economics Class for Students in Accountancy' was introduced in 1933 and in the late 1940s evening courses in economics and business-related subjects were added for part-time professional students.

This brief review of economics provision within the two larger ancient Scottish universities suggests a strong bias towards the first two of Guillebaud's categories of teaching. The orientation of economics teaching in the Scottish universities might to some extent be said to parallel the "political economy' orientation of the discipline in Britain and elsewhere more generally during this period and the textbooks recommended seem relatively orthodox (Dow et al. 1999). It can, nevertheless, be argued that the shape of the curriculum was also influenced by the traditional purposes and characteristics of the Scottish universities - particularly breadth, broad access and vocational relevance - and that, within that framework, the particular stress in political economy on economic history, social problems and policy, and the history of political economy reflects the persistent influence of a Scottish political economy tradition. The inherent emphasis within that tradition on 'applied economics', in the broad sense of engagement with the real world, is matched by the importance given in the honours curriculum to 'social economics' and 'economic history' and by the general orientation towards education with vocational relevance. For example, in the early 1950s all third-year economics undergraduates at Glasgow were required to write a paper of 10,000 words on the subject 'Enterprise, as illustrated by a West of Scotland firm or industry' (Guillebaud 1954b: 213).

It is not being argued here that the characteristic Scottish approach in this period is wholly unique. Economics in Oxford, both before and after the First World War, was also characterised by breadth and openness to cognate disciplines, as well as an emphasis on applied work. In 1921 'the distribution of lecture topics still favoured history and application while the involvement of historians and philosophers in the teaching of economics and economic history remained strong' (Young and Lee 1993: 12). The approach is reflected in the Politics, Philosophy and Economics (PPE) undergraduate curriculum, at least until the 1930s. However, the Oxford approach does not have the wider institutional roots and support to allow it to constitute a 'national tradition' and, indeed, the impressive number of Oxford-Scottish connections during the period might almost justify its characterisation as an extension of the Scottish tradition. Influential Scots in Oxford included the philosopher A. D. Lindsay and, in economics, D. H. MacGregor, ${ }^{9}$ and two Oxford economists with Scottish roots moved to Chairs in Scottish universities between the wars Ogilvie to Edinburgh and Fraser to Aberdeen. ${ }^{10}$ The political economy approach in Oxford, like that which we find in Scotland, can be contrasted with the more formalistic work which was already developing in 
the two leading English centres: Cambridge and the London School of Economics (LSE).

Although practice south of the border may have been more diverse, there is clear circumstantial evidence of important differences between academic economics in Scotland and England. In Guillebaud's illustrative review of undergraduate economics education in Britain, Glasgow (along with Oxford) lies at the generalist extreme of a spectrum running from the broadly based to the narrowly specialist, with Cambridge at the other extreme, and most English institutions probably nearer to Cambridge than to Glasgow. Whilst significant amounts of postgraduate work had developed by the 1950s in the LSE, Cambridge, Oxford and Manchester, it is largely absent in Scotland. The relative extent of specialist work may be reflected by economics staff numbers (Table 13.1).

The six Scottish institutions, a quarter of the British number, contained only one-eighth of university economists. Further evidence of the relatively distinct character of economics in Scotland emerges from an examination of the scholarly output of these Scottish professors of political economy. Research and scholarship were a rather less important aspect of the work of Scottish academics then than they are now and, with the exception of Nicholson and Scott, that is reflected in the quantity of published work. Most of those who held Chairs between 1900 and the 1950s published works of economic history, a field in which Scott (Glasgow) and Hamilton (Aberdeen) were specialists (Scott 1910-12; Hamilton 1932; Smart 1910-17). Work on the history of economic thought and on Smith in particular was common and featured especially in the output of Gray (Aberdeen and Edinburgh) (Gray 1931), Macfie (Glasgow) (Macfie 1967) and Scott. The majority of the remaining publications focused on economic and social problems and policy (Gray 1927; Ogilvie 1933). Smart published translations of works by Böhm-Bawerk and von Wieser, and works codifying economic theory. Nicholson, who, like Scott, Macfie and to a lesser extent Gray, saw himself as a follower of Smith, ${ }^{11}$ was the most prolific author in the group and perhaps the most closely integrated into the core of the British economics profession of his day. Along with a monumental three-volume Principles of Political Economy (Nicholson $1893,1897,1901)$ he published in all the fields dealt with here, focusing

Table 13.1 University economics teachers 1948

\begin{tabular}{lr}
\hline England & 192 \\
Wales & 19 \\
Scotland & 28 \\
Total & 239 \\
\hline
\end{tabular}

Source: Guillebaud (1954b: 221).

Note

Includes teachers of economic history and economic statistics. 
particularly on issues of money, trade and empire (e.g. Nicholson 1888, 1903, 1909).

None of the Scottish professors, however, could be said to have contributed a significant advance to the mainstream corpus of economic theory. The evidence seems to support Macfie's assertion that 'there is little doubt that Scotsmen, while acquiescent, have not been entirely comfortable ... in modern economic theorising ... The trend has been to teach the orthodox line, but to do one's special work in historical, social or semi-philosophical research' (Macfie 1955: 98). That discomfort stemmed from a tradition that was in its philosophical roots both 'realist' and wedded to ideas of social and moral purpose.

\section{Scott and Cairncross in Glasgow}

In a eulogy which seems to catch much of the character of the Scottish approach in political economy, Macfie describes a living tradition in the Glasgow Department of Political Economy which had been 'the special achievement of the two men who had led the Department' before him. Smart and Scott were:

humane, widely experienced scholars. Each of them had the firmest grasp of and respect for facts, human as well as industrial. Their sense of history ${ }^{12}$ and its constant relevance to any finally valuable economic theory is worthy of the master who was their continual joy and inspiration. And their active part in the affairs of a great industrial city was as inevitable as his. In each of them is found that energetic growth from the core of hard facts to their deeper philosophic meanings which was Adam Smith's most shining gift. And each of them contributed his thinking to the direct service of the State on many commissions ${ }^{13}$ and committees, just as did Adam Smith in the more personal, less official manner of his day.

(Macfie 1952: 129)

Here Macfie describes how a particular style of 'applied economics' was integral to political economy in the Scottish tradition. This kind of work developed in Glasgow under Scott's leadership and a characteristic product of the approach is the Industrial Survey of the South West of Scotland produced by the staff of the Glasgow department for the Board of Trade (Board of Trade 1932). ${ }^{14}$ Applied work was later given a notable boost with the appointment of Alec Cairncross to a new Chair in Applied Economics and to lead a newly created Social and Economic Research Department (SERD). A Glasgow graduate (in Political Economy and Politics), Cairncross returned to his alma mater in 1935 as a Lecturer in Political Economy, after a period as postgraduate student and then lecturer in the Cambridge Economics Faculty. ${ }^{15}$ He left again in 1939 to deploy his skills 
in wartime service which led on to the post of Economic Adviser to the Board of Trade from 1946 to 1949.

The objective of SERD was to undertake research on social and economic problems in Scotland (and especially west central Scotland), thereby contributing to policies for economic and social development. Expectations that SERD would generate research commissions from the Scottish Office were, in the early years, disappointed, ${ }^{16}$ however, and Guillebaud (1954b: 230) suggests that 'research on immediate short-term problems [was] only incidental to its main work'. As well as 'occasional papers', the department produced two series of research monographs under the rubric 'University of Glasgow Social and Economic Studies'. The 'Old Series' published in the 1950s under the general editorship of Cairncross centred on the kind of applied work that might be expected, although not all of it relating to Scotland. There were accounts of crofting, industrial relations in Glasgow, the UK shipbuilding industry and wage structure in Britain. There were also two volumes of intellectual history on Smith and Miller.

Perhaps most interesting for us here is 'a statistical account of Scottish life' under the title The Scottish Economy, comprising contributions by a range of Glasgow University staff and edited by Cairncross. In his preface Cairncross notes that the volume aims to analyse those aspects of Scottish life that can be measured quantitatively, arguing that the approach derives from a long-term Scottish tradition, "that of Sinclair, ${ }^{17}$ Cleland $^{18}$ and Giffen, ${ }^{19}$ to name only three of the distinguished Scotsmen who helped to develop the use of statistics as a technique for the analysis of social and economic structure'. At the same time he is clear that it is a partial exercise - a comprehensive picture of the Scottish economy would 'require far more historical depth' and 'more colour and detail of everyday life' (Cairncross 1954: xv). Although in an age of increasing specialisation the Glasgow tradition may at this stage be divided between the more philosophical approach of Macfie and the practical economics of Cairncross, the latter is concerned to link his applied work with important features of the Scottish tradition of political economy.

\section{The Dundee School of Economics}

Evidence for the existence of the Scottish tradition that we describe comes also from those outside it. In the inter-war period there emerged an institutional challenge which indicated the strength of the tradition and sowed some of the seeds of its ultimate demise. There was established in 1931 in Dundee a unique institution which became in the latter part of its twentyone-year life 'a foreign irritant in the Scottish oyster' (Munby 1957: 60). When the offer of an endowment by George Bonar, chairman of the Dundee Chamber of Commerce, to establish a Faculty of Commerce at University College, Dundee (a satellite of St Andrews) was rejected 
because of the open entrance policy which Bonar required, it was taken up by the local education authority, with support from the University of London and the LSE in particular.

The aim of Bonar and the first principal, James Bowie, was to remedy what they saw as the neglect, in the university system, of practical training for the world of business. The initial vehicle for such training was to be a two-year commercial diploma. Such an aim in itself, involving as it does the practical application of economics, seems to fall within the Scottish tradition. Early on, however, the LSE connection asserted itself. J. C. Gilbert and J. K. Eastman, the first two lecturers appointed and, by background, analytical economists from London, were soon joined by Duncan Black (a Glasgow graduate) and R. H. Coase, both from postgraduate studentships at the LSE, and both destined for considerably higher things. The curriculum and approach evolved to match the London University external degree programmes and the institution's name was truncated from 'The Dundee School of Economics and Commerce' to 'The Dundee School of Economics' (Blake and Lythe 1981).

At its peak after the war, and up to its disappearance into the Dundee University College in 1952, there were over sixty students taking London University BCom and BSc(Econ) degrees, a number greater than the total of honours students in political economy in the ancient universities. Despite a demanding teaching load its young staff achieved a high rate of publication in the professional journals, little of which was 'applied economics' in the Scottish sense. The School can be seen as an early 'missionary' incursion by the new analytical economics into the land of political economy.

\section{The Scottish Economic Society}

An indication of the vision of the nature and purpose of economics to which the economics community in Scotland generally subscribed in the 1950s can be glimpsed in the early history of the Scottish Economic Society, (re)formed in 1954 with the aim of encouraging the study of economics in Scotland. Here a further important 'applied' aspect of the Scottish tradition emerges ${ }^{20}$ : the promotion of the discussion of economic ideas and issues among the professional and business community.

A Scottish Society of Economists had been established in Edinburgh under the leadership of Nicholson, its first president, in 1897. In his inaugural address Nicholson proposed that the Society should not be concerned to promote any particular set of practical reforms but should consider the whole range of economic research, including statistical and financial aspects (Campbell 1997: 360). But this was not, in fact, a society of professional economists. Its membership - 108 initially - was made up in the main of members of Edinburgh professional and commercial society. ${ }^{21}$ Although several were leading economists, the speakers covered as wide a range of professional interests as the members. Nicholson 
remained the leading figure in the Society and after his death in 1927 it lapsed into inactivity.

The 1954 reincarnation under the less exclusive title of the 'Scottish Economic Society' (SES) took place on a proposal from the economists in the four Scottish universities (and the Dundee School of Economics). A new constitution was agreed in which:

The objects of the society shall be:

a to advance the study of economic and social problems on the widest basis, in accordance with the Scottish tradition of political economy inspired by Adam Smith;

b to provide a forum for the discussion of Scottish economic and social problems.

(Constitution of the Scottish Economic Society 1957)

The main vehicles for the pursuit of these aims were to be a branch organisation in the four main cities, each running a syllabus of meetings, an AGM with a presidential address, and a new journal, The Scottish Journal of Political Economy (SJPE). Membership of the SES was intended to extend over the whole field of social science.

Economics in isolation from other branches of social science tends to be emasculated ... 'political economy'... is the description that appears on the cover of the Journal, in token of the wish to make room for politics, sociology, economic history and administration while keeping a firm core of economics.

(Cairncross 1954: 2)

Whilst not neglecting theoretical work and the use of new analytical technique the Journal was to be accessible to an educated, but non-professional, audience. Indeed, Cairncross suggests that the SES (in line with the aims of its predecessor society) 'has the opportunity to create a more informed public opinion on economic matters and to encourage a wider and more constructive outlook' (Cairncross 1954: 3). A survey of the contents of the journal and of the syllabuses of the four SES branches up to the end of our period suggests that the Society was fulfilling its objectives. The impact on Scottish public opinion is not, of course, easy to gauge. Branch meetings were addressed by a mixture of academic, business and professional speakers, and covered a wide range of topics, with an emphasis on Scottish economic problems and institutions. Most issues of the SJPE contained articles on economic history, social problems or policies, and history of economic thought (or philosophy). Among the economics pieces, stress is given to economic problems and policy with a bias towards Scottish issues - altogether a representation of the 'applied' element in the Scottish political economy tradition. 


\section{The waning of the Scottish political economy approach}

The years from 1953 until the end of Cairncross's period as editor of the SJPE in 1960 witnessed the final significant attempts to preserve a Scottish political economy tradition against the inexorable rise of the 'analytical' economic approach - an internationalising process in the discipline stemming from the United States and, in Britain, led particularly from the LSE and Cambridge (Backhouse 1996).

Of more than symbolic significance in that process was the arrival in 1957 of (later Sir) Alan Peacock to replace Sir Alexander Gray in the Chair at Edinburgh. It seems as if he was sent from the LSE to bring enlightenment to the benighted northerners. David Simpson, who at that time was a secondyear Edinburgh undergraduate with a mathematical bent, has described his excitement (shared by many fellow students) at the change. After Gray's 'old-fashioned' history of economic thought-based Political Economy class the new 'scientific' analytical approaches 'brought a breath of fresh air', the feeling of being at the frontiers of a developing discipline. ${ }^{22}$ Two years later Simpson was one of eight honours graduates in economics, and along with two or three fellows he was able to exploit the department's new international links to undertake graduate work in the United States.

On the occasion of the centenary of the Scottish Economic Society Campbell asked, 'How then should the century be celebrated? By going back to roots, and by regarding them as pointers to better ways?' (Campbell 1997: 367). Scottish economists have continued to argue for the political economy tradition and the broader applied approach implicit within it (see Cairncross 1970, 1984; Alexander 1975). Simpson, tracing the roots of both back to Adam Smith, puts the case for a re-emphasis on the political economy approach, as against the analytical approach, in the education of economists (Simpson 1988). From the late 1950s onwards, however, degree structures and economics curricula in the ancient Scottish universities began to change. In the 1950s and 1960s four new universities (Dundee, Strathclyde, Heriot-Watt, Stirling) were established and, with the possible exception of Strathclyde, their degree structures and curricula did not reflect the older Scottish tradition. By the 1990s little if anything of the traditional Scottish approach can be detected, even in the ancient universities, and departments of economics in Scotland today look little different from their counterparts south of the border (or in many other parts of the world). At Glasgow, where the tradition may have been strongest and the pace of change slowest, 'Economics' finally replaced 'Political Economy' in the departmental title in 1998.

With the relative demise of the influence of the Scottish political economy tradition has come, in the Scottish universities at least, a decline in the significance of applied work of the kind which we have seen to be associated with that tradition. 


\section{Concluding comments}

This wide-ranging survey has produced much evidence from the practice of economics in Scotland between the 1890s and the 1950s that is consistent with the proposition that a particularly Scottish tradition of political economy continued to have a significant influence. That influence, in part perpetuated by traditions in the institutional make-up of the older Scottish universities, inhibited the development in Scotland of the use of abstract deductive, formalistic economic theory, whilst valuing the pursuit of particular forms of applied economic work. The 'applied economics' inherent in the Scottish approach reflects a view of the importance of history and the limitations of theory, together with a concern to widen the discussion of economic and social issues in society, and to present policyrelated analysis in a form which is accessible to the policy maker.

As Cairncross, perhaps the pre-eminent British applied economist of his generation, wrote: theory is valuable only if it 'does justice to recorded experience', and applied economics must make provision for 'the weaving together of economic and non-economic considerations ... for . . . there is no such thing as economic policy in isolation from other aspects of policy, there is only policy' (Cairncross 1970: 22). Always conscious of his Scottish roots, Cairncross's practical commonsense approach reflects the experience of half a career spent away from academia in economic administration and policy making as 'a highly respected ... member of the economic/administrative establishment' (Roll 1998).

Although Scotland could never have been wholly insulated from developments in economics elsewhere, the influence of Scottish traditions limited the extent of their impact within Scotland. Scotland was not simply a provincial backwater in the empire of economics which, because of its outdated institutions and ideas, took longer than many other 'provinces' to assimilate the developing analytical and formalistic economic science. ${ }^{23}$ Rather, the earlier 'political economy' tradition, which Scottish institutional separateness had helped to forge and to sustain well into the twentieth century, had firmer institutional roots in Scotland than elsewhere in Britain.

This chapter has attempted a kind of 'history of economics' in Coats's sense: 'an exercise in the origins, development, and significance of the changing styles of professional activity' (Coats 1984). In such an exercise the retrospective assertion of 'traditions' in an interpretation of the past will always involve selectivity - some would say 'invention' (Hobsbawm and Ranger 1992) - with the aim of lending support to a particular form of institution or activity on the basis of a suggested lineage. There are, of course, clear historical reasons why Scots may wish to differentiate themselves from the English. In arguing for the existence of a particular approach in Scotland up to the 1950s use has been made of the observations both of Scottish economists - including Macfie, Cairncross and 
Simpson - who may be seen as supporters of the Scottish tradition, and of those, such as Munby, who are not. The data on the nature of economics in the Scottish university curriculum, the work of Scottish academic economists, and the constitution and activities of the Scottish Economic Society, including the content of the Scottish Journal of Political Economy, suggest that substantive evidence of the pursuit of a political economy-related style of applied economics in Scotland up to the 1950s is not hard to find.

The main object of this chapter, then, has been to describe a style of applied political economy which was characteristic of much of the economic studies in the Scottish universities throughout the first half of the twentieth century and to explain how that approach may have been fostered and supported by particular Scottish intellectual traditions and institutional arrangements. The survival of that approach - to a significant extent the result of the unity and continuity of the traditional Scottish university system, the character of its programmes and the place it held in the Scottish economy and society - was also helped by the longevity in post of the relatively small number of academic economists in the four ancient universities. Inevitably the post-Robbins expansion of the university system combined with the internationalisation of economics as a discipline brought a rapid dilution of the influence of that Scottish tradition.

Some of the special circumstances which helped keep that tradition alive remain, perhaps most notably the particularity of Scottish economic development and economic and social policy concerns - both given added salience by political devolution - and there are now signs that the relative profile of 'applied' and policy-related economics (though not necessarily in the Scottish tradition) may be once more on the rise in Scotland.

\section{Notes}

1 Sections of this chapter draw heavily on Dow, A., Dow, S. and Hutton, A. (2000) 'Applied economics in a political economy tradition: the case of Scotland from the 1890s to the 1950s', in History of Political Economy 32 (supplement): 177-98. Copyright 2000 Duke University Press. All rights reserved. Used by permission of the publisher.

2 The social and moral purpose of political economy is often asserted by the leading Scottish practitioners (cf. Smart 1916; Gray 1949).

3 A name it retained until 1957.

4 William Smart had been given a university lectureship in Political Economy in 1892.

5 In Edinburgh: Nicholson 1880-1926, Ogilvie 1926-34, and Gray 1934-56. In Glasgow: Smart 1896-1915, Scott 1915-46, Macfie 1946-59.

6 Held by Gray 1921-34, Fraser 1934-39 and Hamilton 1939-54.

7 Held until the 1960 s by Nisbet.

8 Including, at different times, R. H. Tawney, Thomas Jones and J. H. Jones.

9 In the post-war period G. B. Richardson is an Oxford economist who may be linked with the Scottish tradition.

10 Later, as first vice-chancellor of the new University of Keele, Lindsay introduced a broad-based four-year undergraduate degree structure drawing 


\section{Alan Hutton}

directly on Scottish traditions. A fuller treatment of the relationship between the twentieth-century Oxford approach in economics and the Scottish tradition is beyond the scope of this chapter.

11 With the exception of Scott, who was Irish, all those who held Chairs in Political Economy in the Scottish universities in this sixty-year period were products of a Scottish education.

12 The importance of history in the Scottish tradition is given emphasis by both Campbell (1976) and Cairncross (1989)

13 Smart was a member of the Poor Law Commission and a major author of its majority report. Scott was 'frequently away on some government committee' during Cairncross's days as undergraduate and, later, lecturer at Glasgow (Cairncross 1998: 37, 47).

14 (Sir) Alec Cairncross, who was an undergraduate in the department at the time, reports participating in housing surveys in the city organised by Cunnison, the Lecturer in Social Economics (interview with A. Hutton and M. Keaney 1997).

15 Cairncross was the first Scottish economist to gain a PhD.

16 Cairncross received not one request for advice during his first ten years as professor at the SERD in Glasgow (Coats 1979).

17 Sir John Sinclair (1754-1835): best known as instigator and editor of the Statistical Account of Scotland (1791-79).

18 James Cleland (1770-1840): Glasgow public servant and social statistician.

19 Sir Robert Giffen (1837-1910): economic statistician and applied economist (see Hutton 2004).

20 This is an aspect also evidenced, inter alia, in the major role taken by Smart, Scott, Gray, Cairncross and others in the work of Section F of the British Association for the Advancement of Science.

21 Nicholson was followed in the chair of the Society by three lawyers, an accountant and an actuary (Campbell 1997: 359).

22 Interview with A. Hutton and M. Keaney (1996).

23 Without more systematic comparative data we can say little about differences between Scotland and, say, the north of England in this respect. Phelps Brown, who pursued his career 'south of the border', provides a critical account of developments in the discipline during his lifetime (Phelps Brown 1989) which could have come from a Scottish political economist. Indeed, Cairncross saw him as a kindred spirit (Cairncross 1996). See also Backhouse (1996).

\section{References}

Alexander, K. J. (1975) 'The political economy of change', in K. Alexander (ed.), The Political Economy of Change, Oxford: Blackwell, pp. 109-25.

Anderson, R. D. (1992) 'The Scottish university tradition: past and future', in J. Carter and D. Withrington (eds), Scottish Universities: Distinctiveness and Diversity, Edinburgh: John Donald, pp. 67-78.

Backhouse, R. E. (1996) 'The changing character of British economics', in A. W. Coats (ed.), The Post-1945 Internationalisation of Economics (annual supplement to History of Political Economy 28), Durham NC and London: Duke University Press, pp. 33-60.

Blake, C. and Lythe, E. (1981) 'Introduction' to C. Blake and E. Lythe (eds), A Maverick Institution: Dundee School of Economics Fiftieth Anniversary Commemorative Essays, London: Gee.

Board of Trade (1932) An Industrial Survey of the South West of Scotland (Made for 
the Board of Trade by the Staff of the Political Economy Department of the University of Glasgow), London: HMSO.

Cairncross, A. (1954) 'The Scottish Economic Society', Scottish Journal of Political Economy 1, 1: 1-6.

— (1970) 'The managed economy', in A. Cairncross (ed.), The Managed Economy, Oxford: Blackwell, pp. 3-22.

— (1984) 'Economics in theory and practice', Richard T. Ely lecture, American Economic Review Papers and Proceedings 75, 2: 1-14.

(1989) 'In praise of economic history', Economic History Review 2nd ser. 42, 2: 173-85.

— (1996) 'Henry Phelps Brown', Review of Political Economy 6, 2: 141-4.

- (1998) Living with the Century, Fife: Iynx.

Campbell, R. H. (1976) 'Scottish economic history', Scottish Journal of Political Economy 23, 2: 183-92.

— (1997) 'The Scottish Society of Economists: the Scottish Economic Society, 1897-1997', Scottish Journal of Political Economy 44, 4: 359-67.

Carter, J. and Withrington, D. (1992) 'Introduction', in J. Carter and D. Withrington (eds), Scottish Universities: Distinctiveness and Diversity, Edinburgh: John Donald, pp. 1-14.

Coats, A. W. (1979) 'The changing role of economists in Scottish government since 1960', Public Administration 57 (spring): 399-424. Reprinted in Coats (1993).

- (1984) 'The sociology of knowledge and the history of economics', in W. Samuels (ed.), Research in the History of Economic Thought and Methodology II, Greenwich CT: JAI Press, pp. 211-34. Reprinted in Coats (1993).

- (1993) The Sociology and Professionalisation of Economics: British and American Economic Essays II, London and New York: Routledge.

Dow, A., Dow, S. and Hutton, A. (1997) 'The Scottish political economy tradition and modern economics', Scottish Journal of Political Economy 44, 4: 368-83.

— (1999) 'Scottish political economy, 1850-1950' Glasgow Caledonian University mimeo.

- (2000) 'Political economy and applied economics: the case of Scotland from the 1890s to the 1950s', History of Political Economy 32, annual supplement: 177-98.

— and Keaney M. (1998) 'Traditions in economics: the case of Scottish political economy', New Political Economy 3, 1: 45-58.

Dow, S. (1987) 'The Scottish political economy tradition', Scottish Journal of Political Economy 34, 4: 335-48.

Gray, (Sir) A. (1927) Family Endowment: A Critical Analysis, London: Ernest Benn.

- (1931) The Development of Economic Doctrine: An Introductory Survey, London: Longmans.

— (1949) 'Economics: yesterday and tomorrow', The Advancement of Science 6, 23: 233-43.

Guillebaud, C. W. (1954a) 'General survey', in International Economic Association (1954), pp. 1-35.

— (1954b) 'The teaching of economics in the United Kingdom', in International Economic Association (1954), pp. 199-234.

Hamilton, H. (1932) The Industrial Revolution in Scotland, London: Frank Cass.

Hobsbawm, E. and Ranger, T. (eds) (1992) The Invention of Tradition, Cambridge: Cambridge University Press. 
Hutton, A. (2004) 'Sir Robert Giffen', in D. Rutherford (ed.), Biographical Dictionary of British Economists, Bristol: Thoemmes Press, pp. 422-3.

— and Keaney, M. (1996) Interview with D. Simpson, Edinburgh, unpublished.

— (1997) Interview with Sir A. Cairncross, Oxford, unpublished.

International Economic Association (1954) The University Teaching of Social Sciences: Economics, Paris: UNESCO.

Kadish, A. and Tribe, K. (1993) 'Introduction' to A. Kadish and K. Tribe (eds), The Market for Political Economy: The Advent of Economics in British University Culture, London: Routledge.

Koot, G. M. (1987) English Historical Economics, 1870-1920: The Rise of Economic History and Neomercantilism, Cambridge: Cambridge University Press.

Macfie, A. L. (1952) 'Note on the growth of political economy', in Fortuna Domus, Glasgow: University of Glasgow.

- (1955) 'The Scottish tradition in economic thought', Scottish Journal of Political Economy 2, 2: 81-103.

— (1967) The Individual in Society: Papers on Adam Smith, London: Allen \& Unwin.

Mair, D. (ed.) (1990) The Scottish Contribution to Modern Economic Thought, Aberdeen: Aberdeen University Press.

Munby, D. L. (1957) 'The Dundee school of economics: in memoriam', Scottish Journal of Political Economy 4, 1: 60-5.

Nicholson, J. S. (1888) Money and Monetary Problems, London.

— $(1893,1897,1901)$ Principles of Political Economy, 3 vols, London: Black.

- (1903) The Tariff Question, London.

- (1909) A Project of Empire, London.

Ogilvie, (Sir) F. W. (1933) The Tourist Movement: An Economic Study, London.

Phelps Brown, H. (1989) 'The radical reflections of an applied economist', in J. Kregel (ed.), Recollections of Eminent Economists II, London: Macmillan, pp. 197-207.

Rankin, M. (1955) 'The founding of the Chair of Political Economy', Edinburgh University Journal 18: 191-9.

Robinson, J. and Eatwell, J. (1973) An Introduction to Modern Economics, Maidenhead: McGraw-Hill.

Roll, E. (1998) 'The practical economist', The Guardian, 24 October.

Rutherford, D. (1997) 'History of the (Edinburgh) Economics Department', http://www.ed.ac.uk/econ/General_History.htm.

Scott, W. R. (1910-12) The Constitution and Finance of English, Scottish and Irish Joint Stock Companies to 1720, 3 vols, Cambridge: Cambridge University Press.

— (1916) Second Thoughts of an Economist, London: Macmillan.

Simpson, D. (1988) 'What economists need to know', Royal Bank of Scotland Review 160 (December): 3-11.

Sinclair, (Sir) J. (ed.) (1791-99) Statistical Account of Scotland.

Smart,W. (1910-17) Economic Annals of the Nineteenth Century, 1801-1820, 1821-1830, 2 vols, London: Macmillan.

Tribe, K. (1988) Governing Economy: The Transformation of German Economic Discourse, 1750-1840, Cambridge: Cambridge University Press.

Young, W. and Lee, F. (1993) Oxford Economics and Oxford Economists, London: Macmillan. 


\title{
14 Postscript
}

\author{
Sheila Dow
}

The purpose of this postscript is to provide a brief review of what the chapters in this volume have revealed about the history of Scottish economic thought. Such an exercise is of course fraught with historiographical issues. There are well rehearsed difficulties in attempting, inevitably from a later perspective, to interpret old texts and the figures who have produced texts of particular influence. (The passage of time simply adds an important layer on to the issues of interpretation of the work of contemporaries.) The authors in this volume have all aimed to interpret texts and figures as faithfully as possible to their context and authors' intentions, though these contributions too must be the objects of interpretation.

Rather than becoming mired in relativism, however, we as editors can help readers to make their own interpretations as far as possible by being explicit about the perspective of our own interpretation. Our perspective, set out in Chapter 1, is that there has been continuity in the history of Scottish economic thought which has extended beyond the period of the Enlightenment; it is the eighteenth century which has more commonly been understood as the time frame of any Scottish tradition. Further, this continuity has been evident in terms of philosophical and methodological approach rather than in terms of content as such. In so far as they were interested in addressing it, this perspective provided a frame of reference for contributors to this volume.

What we have seen is a series of accounts of a complex evolution of thought, incorporating many influences into a range of theories and policy prescriptions addressed to an evolving economic reality. Our interpretation as editors is that there is insufficient contrary evidence provided here to challenge our view that there was a Scottish tradition in terms of approach to economics which continued up to the twentieth century. Nevertheless the tradition has weakened over the years, and is barely evident in twenty-first-century Scotland. Consistent with the methodological approach of the Scottish tradition, this conclusion is reached having identified a pattern from detailed study of individual texts and authors, but the conclusion is not a universal one - there are exceptions. 
The tradition is Scottish in that it is identified so strongly with key figures of the Scottish Enlightenment, notably Hume and Smith (who in turn were influenced among other things by their Scottish background), and then continued through the personal influence of other Scottish figures. The figures who adopted the Scottish approach were not necessarily Scottish by birth (see for example Hutcheson); nor did Scottish birth ensure loyalty to the Scottish tradition (see for example James Mill). Further, Scottish thought by no means developed in isolation. Indeed, the strong influence of Continental philosophy and the emergence of Newton's system of science had a powerful effect on the character of the Scottish approach.

But the tradition is also Scottish in that it was both formed and perpetuated through particular institutional arrangements in Scotland. The history of Scottish political arrangements, the separate institutions of education, law and religion, and the manifest need in the eighteenth century for practical reason as the basis for economic development, in a relatively small, cohesive society, all coalesced to forge a distinctive approach to economics. Further, the persistence of these separate institutional arrangements served to maintain some of that distinctiveness up to the twentieth century. But thought evolves as the surrounding conditions change. Scotland has continued to absorb outside influences, and these have tended to lead to an increasing homogenisation of economic thought with international conventions in thought.

But, just as Scotland has absorbed ideas from elsewhere, Scottish economic thought in turn has had an influence on the development of economic thought elsewhere, to the extent that Adam Smith is often referred to as the 'father' of modern economics. Indeed, it is conventional in introductory texts to put it more strongly. For example, in a widely sold introductory textbook, Parkin et al. (1997: 13) assert with respect to economics that '[i] ts birth can be dated fairly precisely in 1776 with the publication of the Wealth of Nations'.

We will proceed now to consider the influence of Scottish thought separately in terms of the content of economic theory, and the approach to economics, respectively. Since ideas are understood, and interpreted, differently depending on the approach of the reader, there has been scope for the influence of economic theory and also methodology to be diverse, and not necessarily consistent with what was intended by the relevant author. Indeed, interpretations of Smith and Hume in particular, drawing on different approaches to economics from the Scottish tradition, have had tremendous influence, even though the outcome may be inconsistent with the Scottish tradition. First we consider briefly how the content of the development of economic thought has been influenced by Scottish thought. In the following section we consider the influence of the approach by which we have identified the Scottish tradition. 


\section{Influence on the development of economic theory}

To identify the sources of ideas is a contentious business. Further, ideas take on much of their meaning from context, so that they should not be considered in isolation. So there is no claim here that the ideas which influenced the development of modern economic theory originated in eighteenth-century Scotland in any absolute sense. Nevertheless, the expression and development of these ideas by Scottish Enlightenment thinkers, and most particularly Adam Smith, proved to be highly influential for the emergence of political economy as a discipline, and the questions it addressed.

The questions were those posed by the emergence of commercial society, embedded in wider questions about the individual within society. Andrew Skinner shows (in Chapter 3) how the seeds of Smith's theories of value, of money and of the division of labour can be found in the work of his teacher, Hutcheson (and before him in Pufendorf). These were questions about how the emerging system of specialised production and monetised transactions actually worked, and how the economic actions of individuals could be co-ordinated. In terms of Smith's philosophy of science, this new mode of operation, when not understood, created a sense of unease which provided a motivation for philosophers to improve understanding. It was Smith's great achievement to present this mode of operation as a system, and a system which could generally (but not universally) co-ordinate itself. While it was not widely appreciated in Smith's own time, this system in due course provided the foundation for classical economics (Boulding 1971; Hollander 1973; O'Brien 1975). The subsequent interpretation of the market system as one which was susceptible to formal mathematical treatment extended Smith's influence to the development of general equilibrium theory in the twentieth century (Arrow and Hahn 1971).

But this was not the only interpretation which proved influential. Marx adopted the Scottish stadial view of history. While he put a different interpretation on the nature of commercial society from the conventional interpretation of Smith (Marx seeing the market system as ultimately selfdestructive), nevertheless he drew on Smith's analysis (Heilbroner 1986). Others adopted Smith's views on market co-ordination as being much more benign, but maintained the active role of human agency which disappeared in general equilibrium theory. Thus Smith was also an influence on the neo-Austrian approach; indeed, both Hume and Smith influenced the particular Austrian critique of historicism (Cubeddu 1993: 34).

There were, further, specific policy-related questions which demanded attention, concerning the free-trade issue, public finance and monetary arrangements. Smith used his theory of the division of labour to make the case for free trade, challenging the incumbent mercantilist theory of trade, setting an agenda for trade theory to be taken forward by others, 
particularly Ricardo. Meanwhile Steuart provided the basis of the influential infant industry argument for an exception to free trade.

As far as monetary arrangements were concerned, commercial banking had been in operation in the UK only since the end of the seventeenth century. In Scotland banknotes were of small enough denomination to be widely used as a means of payment instead of specie. This allowed the expansion of bank credit, which fuelled economic growth. We see in the various discussions of money on the part of Law (Chapter 2), Hutcheson (Chapter 3) and Hume (Chapter 4) that there was marked disagreement on this subject. But Hume's account of the price-specie-flow mechanism proved to be a powerful influence, being seen as an early statement of the quantity theory of money and thus of monetarism (and in particular global monetarism; see Frenkel and Johnson 1976). In contrast, while Law's ideas are a remarkably early statement of modern endogenous money theory, he has not been given due credit in the literature (Chapter 2).

It should be noted, further, that the ideas of the Scottish Enlightenment had a particular resonance for the newly forming society in North America, facing particular issues of economic organisation and economic development. Steuart's arguments for tariffs were particularly influential. Rae was later to influence the analysis of economic development in Canada, and is credited by some with inspiring the development of American institutionalism.

The nineteenth-century figures we have considered (James Mill in Chapter 8, McCulloch in Chapter 9, Chalmers in Chapter 10 and Rae in Chapter 11) were men of influence each of whom made his contribution to theory and/or policy. James Mill played an important part in the development of utilitarian ideas in economics, and McCulloch, among other contributions, was pivotal in the development of the theory of public finance. Chalmers made a range of contributions to classical theory as well as to social policy, while Rae extended Smith's theory of economic development with his emphasis on innovation as prior to the division of labour.

None was of the stature of Smith or Hume in terms of (perceived or actual) influence on the development of economics, and we can identify many reasons for this. But one reason worth noting is the methodological divide which was opening up between economic theory in the utilitarian/Ricardian mode and the Scottish approach. McCulloch for example rejected the Ricardian notion of an invariable measure of value and theory of comparative cost. Chalmers fell out of favour with reformers of the Poor Laws (such as Senior) because he saw moral education as the primary mechanism of behavioural change, as the preferable mechanism for relief of poverty (Dow et al. 2003). This was characteristic of the Scottish approach, in that, in O'Brien's words (p. 175 of this volume), they 'wove together a complex picture of a growing economy, paying careful attention to a wide range of institutional and quantitative considerations'. The Smithian outcome was general principles drawn from (often 
quantified) experience, but which were provisional and subject to exceptions. This contrasted with the emerging preference for theorising and modelling which yielded universal conclusions.

This picture of lessening influence within the discipline, combined with a growing divergence from mainstream methodology, is even more evident for the twentieth-century figures (Nicholson, Smart, Scott and Cairncross) considered in Chapters 12 and 13 in the broader context of economics in the Scottish universities. Nevertheless, there is good reason to consider their work for its own sake, in a history of Scottish economic thought. Indeed, their importance lies in their efforts to continue the Scottish tradition in their writings on key figures in the older Scottish tradition, in their teaching, and in providing the theoretical and empirical basis of policy advice. While these figures are not known for their contributions to theory, the role they gave to theory is important. In contrast to the divergence between theorists and the historical school in England, the Scottish political economists actively combined theory and evidence. But their importance also lies in their part in the design of institutions for fostering links between universities, government and society, for the nurturing of a tradition which is identified with the need to draw on philosophy and history as well as economic theory and evidence in order to address practical problems.

By considering Scottish economic thought over three centuries, we have been able to consider how far there has been a distinctive Scottish approach to economics which justifies a national history on grounds which are not merely geographical. We turn now to consider that methodological approach, and how far it itself has had, or has the potential for, influence beyond Scotland.

\section{Influence on the development of economic methodology}

We have seen the approach of the Scottish Enlightenment thinkers continuing in some form through much of Scottish economic thought. But we see for example in James Mill the influence of the quite different Ricardian approach which came to dominate much of economics. Ricardian economics can still be said to have absorbed the influence of Scottish economic thought in terms of questions addressed, and in terms of theory. But both questions and theory underwent a change as economics came to be developed in line with an approach quite different from the Scottish tradition. Smith's system was being formalised, and the detailed historical approach was being lost, along with the understanding of economics as a moral science (Young 1997). Theory was no longer an attempt to draw provisional principles from detailed study of different contexts, with policy prescription based then on an adaptation of theory to context, as a persuasive account. Economics became rather an attempt to construct abstract theory for universal application. 
Smith was probably the most abstract of the Scottish figures, and was more inclined than, say, Steuart to express general propositions (see Chapter 5, this volume). But a glance at the Wealth of Nations is sufficient to reveal the extent of the cases he considered, and his readiness to explore exceptions. The Scottish tradition became increasingly associated in the late nineteenth and twentieth centuries with more systematic detailed statistical work; but rather than being an example of empiricism (understood as the dual of deductive theory), this approach employed the ('real') Newtonian method of interplay between observation and analysis. Thus while the Scottish tradition became less associated with contributions to theory, theory continued to play a central role in economic teaching and research.

Much of the theoretical influence from Scottish thinkers embodied methodological influence, notably in interpreting the Scottish systemic approach, built on a theory of self-interested individual behaviour, as preparing the ground for general equilibrium theory, built on rational economic man. But this is widely understood now to be a misinterpretation of the Scottish Enlightenment approach, something which has been explored here in different ways in Chapters 6, 7 and 8. Indeed, Smith himself would have understood the psychological appeal of a simple formal system such as general equilibrium theory, just as he saw the appeal of Descartes's system, in spite of characterising it as 'one of the most entertaining Romances that has ever been wrote' (Smith 1985: ii.134). The fact that Smith's economics proved to be more influential in the long run than Steuart's, for example, may be understood partly in terms of Steuart's greater focus on the limits to generalisation.

As Skinner (1996: 21) points out, Smith distinguished between the principles of discourse, where elegance and simplicity persuade, on the one hand, and the principles of scientific enquiry, on the other. The way in which Smith's system was developed by others along deductivist lines may well be understood as the result of later economists not taking on board Smith's work on rhetoric, which distinguished between the formulation of economics and its communication. The mode of persuasion itself became the method of formulation. As Hutchison (1988: 355) has noted, the unintended consequence of Smith's work was to establish political economy 'as a separate autonomous discipline'.

It is perhaps only now that the formalist, rational-economic-man approach is so firmly embedded in the discipline that the relevance of the Scottish approach is most evident. A range of literatures has developed in reaction to the modern orthodoxy which either explicitly draws on the Scottish approach, or which can be seen to be consistent with it. In the modern methodology literature, therefore, we either see the influence of the Scottish approach or we see the potential for drawing on it anew.

Indeed, we can understand modern methodological thought in relation to the origins of the Scottish approach reflexively, by adopting the latter approach itself. The Scottish approach employed an analytical use 
of history, treating historical evidence not as infinitely diverse, but rather using such similarities as could be identified in order to derive principles. Thus, while we have emphasised the importance of awareness of context in understanding ideas, it is also useful to draw implications from some similarities of context between the eighteenth century and the modern era (as well as the early years of the twentieth century).

The Enlightenment was a period of challenge to (religious) authority in the face of social and economic upheaval which, in Scotland, was combined with the well honed sense of 'otherness' characteristic of small nations with large neighbours. Out of this emerged an approach to knowledge which was realist in the sense of being based on belief in existence as well as being focused on real issues, but which saw knowledge as provisional, and with less than universal application (Wright 1983).

There are some similarities with the early years of the twentieth century, with its rejection of Victorian certainties against a background of social and economic upheaval. This was the context of Keynes's innovative approach to the building of provisional knowledge under uncertainty, which some have seen as influential for modern methodological discussion. (And Keynes was a noted Hume scholar; see Carabelli 1988.) Andrew Skinner (1972) drew attention too to the way in which Shackle's (1967) psychological account of economic enquiry in the 1930s mirrors that of Smith. More recently, modern discussion of economic methodology has developed by drawing on philosophers of science who challenged the certainties of logical positivism which have continued to have an influence on mainstream economic practice.

Skinner (1972) has explored the similarities between Karl Popper and Thomas Kuhn's approaches to the philosophy of science and Smith's essay on the 'History of Astronomy'. Then Howell (1975) drew attention to Smith's pioneering approach to rhetoric, which was taken up by Skinner (1996: ch. 1). Indeed, the revival of interest in the role of rhetoric in economics, spearheaded by McCloskey (1986), is drawing attention to the ways (other than internal logic) in which economists persuade. Brown (1994) has applied this discourse approach to Smith himself. But it should be noted that Kuhn and Popper's work developed without reference to Smith's philosophy of science, and McCloskey's work developed without reference to Smith's pioneering work on rhetoric. Nevertheless we see the potential for ideas from the Scottish tradition to inform the further development of modern methodological thought.

Loasby, more generally, by drawing explicitly on Hume and Smith, has developed his theory of the organisation of knowledge in parallel with his theory of economic organisation. In his discussion of closed models and open systems Loasby draws on Smith's notion of a system understood in terms of connecting principles, noting that Smith's first statement of the principle of the division of labour arose in his psychological theory of the growth of knowledge (Loasby 2003). Indeed, he justifies his focus on 
Smith's theory of knowledge partly by 'its resonance with contemporary evolutionary ideas' (ibid.: 296).

The reference back to the Scottish Enlightenment to support alternatives to modern orthodoxy is not always favourable, however. Hume in particular is seen as having paved the way for logical positivism by apparently identifying cause with event regularity. Critical realists in particular identify the modern reliance on econometric testing, but also the (closedsystem) structure of mainstream theory, with Hume (Lawson 1997). Here we have another example of how Scottish thought can be interpreted differently, depending on the approach to economics of the interpreter. Logical positivism can indeed be traced to Hume according to an interpretation which is inconsistent with the Scottish approach. But by focusing on the context and intentions of Hume we can interpret him quite differently, indeed as a non-positivist realist (Dow 2002a, b). Hume's influence on subsequent philosophy of science, while great, may thus be quite at odds with what he intended.

\section{Conclusion}

To conclude, we (as editors) have attempted here to provide a picture (which is inevitably only partial) of the history of economic thought in Scotland. In the Scottish tradition, however, we have suggested how that history might be approached analytically, teasing out patterns in terms of approach to the subject of economics, while the subject matter (and thus the content of that economics) has inevitably undergone change. Further, continuing in the tradition, we can use the ideas developed in one context to illuminate ideas developing in the modern context, suggesting the potential for the continued relevance of the Scottish approach to economics. But, further in line with the Scottish tradition, while the expression of any interpretation involves some element of persuasion, we put forward our interpretation as being contestable. Readers can reach their own conclusions.

\section{References}

Arrow, K. and Hahn, F. H. (1971) General Competitive Analysis, Edinburgh: Oliver \& Boyd.

Boulding, K. (1971) 'After Samuelson, Who Needs Adam Smith?', History of Political Economy 3, 2: 225-37.

Brown, V. (1994) Adam Smith's Discourse: Canonicity, Commerce and Conscience, London: Routledge.

Carabelli, A. (1988) On Keynes's Method, Cambridge: Cambridge University Press.

Cubeddu, R. (1993) The Philosophy of the Austrian School, London: Routledge.

Dow, A., Dow. S. and Hutton, A. (2003) 'Thomas Chalmers and the Economicsand-Religion Debate', in D. Hum (ed.), Faith, Reason and Economics: Essays in Honour of Anthony Waterman, Winnipeg: St John's College Press. 
Dow, S. C. (2002a) 'Hume and Critical Realism', Cambridge Journal of Economics 26, 6: 683-97.

— (2002b) 'Interpretation: the Case of Hume', History of Political Economy 34, 2: 399-420.

Frenkel, J. A. and Johnson, H. G. (1976) The Monetary Approach to the Balance of Payments, Toronto: University of Toronto Press.

Heilbroner, R. L. (1986) The Essential Adam Smith, Oxford: Oxford University Press.

Hollander, S. (1973) The Economics of Adam Smith, Toronto: University of Toronto Press.

Howell, W. S. (1975) 'Adam Smith's Lectures on Rhetoric: an Historical Assessment', in A. S. Skinner and T. Wilson (eds), Essays on Adam Smith, Oxford: Oxford University Press.

Hutchison, T. W. (1988) Before Adam Smith: The Emergence of Political Economy, 1662-1776, Oxford: Oxford University Press.

Lawson, T. (1997) Economics and Reality, London: Routledge.

- (2003) Reorienting Economics, London: Routledge.

Loasby, B. J. (2003) 'Closed Models and Open Systems', Journal of Economic Methodology 10, 3: 285-307.

McCloskey, D. N. (1986) The Rhetoric of Economics, Brighton: Wheatsheaf.

— (2001) 'The Genealogy of Postmodernism: an Economist's Guide', in S. Cullenberg, J. Amariglio and D. F. Ruccio (eds), Postmodernism, Economics and Knowledge, London: Routledge.

O'Brien, D. P. (1975) The Classical Economists, Oxford: Oxford University Press.

Parkin, M., Powell, M. and Matthews, K. (1997) Economics, 3rd edn, Harlow: Addison Wesley Longman.

Shackle, G. L. S. (1967) The Years of High Theory, Cambridge: Cambridge University Press.

Skinner, A. S. (1972) 'Adam Smith: Philosophy and Science', Scottish Journal of Political Economy 19: 307-19.

— (1996) A System of Social Science: Papers Relating to Adam Smith, 2nd edn, Oxford: Clarendon Press.

Smith, A. ([1776] 1976) An Inquiry into the Nature and Causes of the Wealth of Nations, edited by R. H. Campbell and A. S. Skinner, Oxford: Clarendon Press.

— ([1795] 1980) 'The History of Astronomy', in Essays on Philosophical Subjects, Glasgow edition, edited by W. Wightman and J. C. Bryce, Oxford: Oxford University Press.

(1985) Lectures on Rhetoric and Belles Lettres, edited by J. C. Bryce, Indianapolis IN: Liberty Fund.

Wright, J. P. (1983) The Sceptical Realism of David Hume, Manchester: Manchester University Press.

Young, J. T. (1997) Economics as a Moral Science: The Political Economy of Adam Smith, Cheltenham: Edward Elgar. 


\section{Index}

Aberdeen University 198-9, 210, 215-16, 232-4; calendar 219

abstract deductive theory 220, 228, 240

abstraction 75, 96, 114; diminishing levels of 79

Addison and Steele 50, 52, 55, 65

aesthetic 125, 137-40, 142-3; judgements 6 , 137-8; objectivism 137; qualities 125 , 131-2, 139, 142; standards 132, 137-8, $140-1$

Age of Experiments 123, 125-6, 132

agriculture 58, 73, 79, 90-1, 96, 166-7, 180-1, 183-6, 189, 191; and commerce 77;

crofting 236; domestic production 175 ; farmers $61,80,154$

analysis $75,106,141$; of economic development 236, 248; and synthesis 117, 129, 133

analytical economics 104, 114, 221, 229, 237-9

applied economics 8, 222, 228-30, 233, 235, 239-41; Scottish 220

approbation 29-30, 42, 48

Aristotle 77, 104, 218; civility 66; distinction 127; method 124, 140; natural philosophy 124

arts 50, 52-5, 61-2, 66; and sciences 58

Austrian school of economics 210, 221-2; neo-Austrian 247

authority $53,78,93-4$; respect of 50

axiomatic-deductive methodology 6, 103-5, 115

Bacon, Francis 114, 127, 129, 223

balance 29, 112; of payments 87

Bank Charter Act 1844171

Bank of England 12, 21, 171; founder of 23

banks 4, 9, 15-18, 20, 24, 166, 171; British

Linen Company 23; credit expansion 249; deposits 10; failures 19, 21, 170; land 12-13, 24; money 9-10, 24-5; notes 12, 16, 21; paper money 17, 19; of Scotland 5, 16, 23-5; Scottish notes 248

barter 33, 142; economy 41-2 beauty $125,137-8$; of language 139

Bentham, Jeremy 6, 147, 161

Berkeley, George 60, 143

Böhm-Bawerk, E. 199, 203-4, 210, 221, 234

Caird, Edward 221, 223

Cairncross, Alec 2, 8, 235-6, 239, 240, 242

Cambridge University 220, 234, 239; economics faculty 235

Canada 198-9, 210, 249; colonial status 200; economic conditions 207; emigration to 209; French community 199; Scottish community 198

Cantillon, Richard 60, 79-80

capital 6, 168, 186, 201, 203-4, 211; accumulation 157, 159, 166-7, 170, 201, 204-5; allocation 169, 173; base 12, 20; flight 173 ; investment 159 ; levy 174 ; liquid 58; market 17, 24; stock 189, 207, 210

capitalism 59, 157, 159, 181, 186, 188, 199, 208

Carmichael, Gershom 31-2, 34

Cartesian philosophy 6, 114, 117-19, 130, 133, 137; aesthetics 138; legacy 112; method 127

Chalmers, Thomas 1, 7, 214-15, 248; biographical notes 178-80; Bridgewater Treatise 189; Christian and Civic Economy of Large Towns 183; An Enquiry into the Extent and Stability of National Resources 179;

Literary and Ecclesiastical Endowments 187; macroeconomics 184; Political Economy 183, 189; reputation 189

Church establishment 22, 179, 186-9

Church of Scotland 146, 190; General Assembly of the 187, 202; Great Disruption 7

civic humanism 49-50, 55

civic republican tradition 50, 66

coffee-house crowd 50, 65

colonies 98, 174-5, 199; powers established 58 ; transportation to the 50

commerce 36-7, 47-50, 52-5, 61-2, 66, 216; benefits from 46; Dundee Chamber of 236; 
international 48, 57, 59, 67; Navigation Acts 57; stages of 77, 90; standards 38; treaties 172

commercial society 48-9, 56-7, 62-3, 65, 248

commodities 16, 41, 110, 155; artificial 35; circulation 59; colonial 53; demand for 169; exchanged 157; increased numbers of 61 ; price of 155 ; real value of $81,83,87$; shortage 82

common sense 123-6, 129-37, 140-2; influence of 132; philosophy $6,143,148$ communications 66,166 ; foreign 85 ; open 54,58 ; problems of 97

comparative advantage 171, 199, 207-8 comparative cost theory $7,207,248$

competitive advantages 59, 98

conceptual system 74, 123, 142

constitution $48,56-8,63,67$

constraints 92, 96, 190; constitutional 94

consumers 53, 173, 210, 221

consumption 92-3, 157-9, 181, 204, 217; conspicuous 208-9; domestic 93, 172, 190; expenditure 24; immediate 157, 159-60; laws of 149

Corn Laws 167, 174-5; debate 91

credit 15-17, 24, 67; British 223; instruments 60 ; money and 18, 59-60, 63; public 48, $62-3$

currency 60; depreciation 16, 168, 170, 174; excess 170; supply 170

Darien scheme see South Sea Company

debt 67; burden 170, 174; low-coupon 173; management 12,18 ; public 62,93

deductive economic theory $6,75,128,151-4$, 155-6, 220, 229; analytical approach 161; methodology 149, 214, 222, 231

demand 10, 34-6, 84-8, 190; for agricultural produce 91 ; annual 158; effective 110; for goods 53, 61; for liquidity 170 ; local 91 ; for money 11,16 ; role of 168 ; shifts in 24 ; shortfalls in 157; and supply 39,217 ; transfer 172

Descartes, René 6, 104, 108, 113-14, 119, 129, 251; Discourse of Method 127

didactic style 139-40, 142

diminishing returns 183, 185, 191, 204

discipline 50, 52, 62-4, 229

diversity 132, 137 see also unity

division of labour 7, 31-3, 65, 80, 141-2, 166, 172, 201, 205, 248-9; commanded 43

Du Tot, Nicolas 15-16, 25; Réflexions politiques sur les finances et le commerce 14

Dundee University College 236-7; School of Economics 237-8

East India Company 147, 175

ecclesiastical politics 187, 192

economic analysis 30-1, 155-7, 160, 179-80, 183,190 economic development 11, 91, 200, 249; blocked 10; in Canada 7, 199; constraints on 79 ; national decline 208 ; theory of 76 , 249

economic growth $167,170-3,189,204-5$, 248; demand-led 5; fluctuations 47; process $50,58,166$; social and psychological costs of 42

economic history 220, 228, 232-4, 238; course 218

economic policy 88, 92, 96, 238; debates 193; relevant areas of 96

economic theories 102, 152-3, 194, 216, 220, 228, 235, 248; content of 246; methodology 251; and policies 2, 10; reductionism 48; testing 251

economic thought 1, 4, 213; development of 32, 202-3; establishment 220; evolutionary 149, 209-10; historians of 31; as a moral science 250; in Oxford 233

economics 54-5, 64, 81, 83, 208, 216-18, 222-3, 229-30, 233, 239, 241, 248; early history of 125, 163, 240; English historical school of 219-20, 228, 249; laws 94, 135; Marxist 210; practical 237; in Scotland 224, 229, 242; stability 171 ; stagnation 10 ; studies 228, 231, 241; teaching of 231, 237 economics as a university subject 136, 178, 214, 218, 228, 231-3, 241; curricula 239; in England 220; lecturers 218, 232, 235; research 234, 237, 250

economics in Scotland 229-30, 234, 237; practice 240; in Scottish universities 2, 231, 233, 238

economists 76, 111, 193, 214, 221; in England 191; in Scotland 230; Scottish-born economists 9

economy 49, 53, 63-4, 78, 153; growing 175 ; policy 93; of scale 207; structure of the 166

Edinburgh Review 165, 189; editor 164

Edinburgh University 7, 71, 107, 112, 118, 146-8, 161-3, 186, 194, 198-9, 210, 215-16, 220, 224-5, 232-4; calendar 216;

Department of Commerce 232; Economics curriculum 232; New College 187

education 146-8, 166, 174-5; authority, local 237 ; breadth of $210,214,224,229,233$; of circumstances 189 ; in economics 213 ; general 232; higher 214, 223, 229; in pure mathematics 114; reform 148; research and scholarship 234, 236; system 210; with vocational relevance 233

eighteenth century $1,14,25,47,88,96,137$, 143, 155, 245; economic development 247; Scotland 4, 5, 151, 160

emigration 174, 187, 198-9; assisted 174

employment 11, 50, 87-90, 157, 172, 180-1; full 155; problem 60; range of 230; of soldiers 182

Encyclopaedia Britannica 147 
England 12, 47, 56, 89, 98, 230; trading network 57

Enlightenment, the 1-3, 10, 245, 251; aesthetic theory 137; European 9; French $3,6,107,114$; key figures 98 ; thinkers 213-14

equilibrium 82-3, 112, 184, 220; condition 187 esprit systématique 127-8, 131-2, 142 ethics 32, 116, 147; ethical perspective 223

Europe 48, 53, 79, 88-9, 90, 93, 199; contemporary 97 ; trading nations of 86 exchange $35,41,49,57,82,142,170$; by barter 37; benefits from 208; commodities 43; between communities 208; equivalent 77,80 ; laws of 135,149 ; of luxuries 207 ; in non-luxury goods 207; rate 35-6, 40-1; real and nominal 170; unsuited for 34 ; value 33 , 37, 39-42, 168; willing to 38

exchange economy 79, 88, 92; emergence of 78 ; institutions of 84 ; modern 80

experience 129, 131, 133-5, 141-2, 240; common 129, 138, 140; historical 90, 160; knowledge from 148, 252; from ordinary life 137-8; role of 124

experimental philosophy 104-5, 118, 128, 143; methodology 124, 127, 132-3, 142

experimentation 115, 123-5, 127-31, 133-5, 138, 140, 142; practical 127; use of precision instruments 126

financial crises 14, 23, 170, 173

financial innovation 16-18, 21, 24-5

food 78-9, 184-5; annual production 181; exchange value 180 ; and population growth 182; prices 223; requirement 180 ; shortage 91, 223

France 4, 114, 119; bankruptcy 12; Cartesianism 113; economic problems 10; financial crisis 12; Law's system 21; national debt 17-18; Regent 13; scientific institutions 112-14

free trade 96, 172, 200, 206, 208, 217, 247-8; with colonies 72; internal and external 166

French economy 11, 13, 43, 72, 157; political 14

general economic equilibrium theory 102-4, 110-12, 115-16, 118, 247, 250

Germany 73, 98

Gide, Charles: Political Economy 217, 219

Giffen, Sir Robert 216, 242

Glasgow 91, 213; industrial relations 236; merchants 91; slum 179; Theorists 91

Glasgow University 7, 27, 107, 113, 215-17, 221, 232-6, 239, 242; Department of Political Economy 217, 235; economics class 233; lectures 194; professors 107, 221; Scottish Economy, The 236-7; Social and Economic Studies 236

gluts, general 156-9, 191; solution to 157 gold and silver 20, 24-5, 57, 154;

demonetised 18

gold standard 171, 223

goods and services 38, 41, 77; exchanged for money 42; intrinsic value 83 ; price 79

government 30, 49, 61-2, 86, 94, 147-9, 153, 166, 173-4, 181-2; absolute 93; civil 95; debt 5, 12, 17; economic functions 216; feudal 77, 79, 90; fiscal power 190; head of 89; intervention 55, 59, 201-2, 206-7;

limited 161; measures 156; mixed 57; nontyrannical 54; notes, interest-bearing 62; republican and monarchical 56-7, 86, 94; role for 56-7, 61; securities 18, 24; tyrannical 66-7

gravity 104, 106, 109-10, 113-14, 128-9, 135, 143; power of 130-2, 142; universal law of $104,118,124$

greatest happiness principle 147, 149, 203

Guillebaud, C. W. 231, 233-4, 236

Hamilton, Alexander 98

Hamilton, Robert 163, 174

Heriot-Watt University 239

historical approach 77, 115, 140, 150, 231; to economics 220-2, 223-4

history 97, 224, 229, 233; of economic thought 234, 238, 245, 249, 251; of the sciences 108

Hodgson, William 216

human capital 166; investment in 173

human nature $5,137,148-9,210$

Hume, David 1, 3, 5-6, 9-10, 14-15, 18, 20-5, $80,84,92,98,107,132,136-8,140,142,150$, 154-6, 169, 190, 193, 211, 215, 246, 248, 251; biographical details 46; experimental method 133, 137; History of England 64; interpretation 134; monetary theory 160; Of Avarice 65; Of Commerce 58, 64; Of Money 154, 156, 190; Of National Character 66-7; Of Parties in General 67; Of the Rise and Progress of the Arts and Sciences 67; On the Standard of Taste 137; philosophy 143; Political Discourses 14-16, 23, 60, 64, 154; political economist 65 ; social context 64 ; theory of money 6 ; A Treatise of Human Nature 46-7, 60, 133; view of common sense 134

Hutcheson, Francis 1, 5, 22, 80, 107, 138, 142, 143, 174, 246-8, 250; economic analysis 27; economics 31; influence on Smith 31; An Inquiry Concerning Beauty, Order, Harmony, Design 138; political ideas 30; A Short Introduction to Moral Philosophy in Three Books 31 ; treatment of value 31

incentives 52-3, 55, 59; to save 205 income 41-2, 159, 203; circular flow of 157; distribution 184, 217; increase 11, 61; per head 172; real value of 42-3; stabilised 91; tax 172-3 
inductive approach 75, 115, 214, 222, 231

Industrial Survey of the South West of Scotland 235

industrialisation 205, 209

industry $33,50,53-5,58,61-2,77-80,88$, 92-3, 95, 154, 156; and commerce 53-4; established 200; expansion of 63; incentives for 84,172 ; protection 59, 172, 206

infant industries 87, 91, 98, 206, 248; promotion of 207, 208; protection of 201, 206-7

inflation 10-11, 16, 60, 62, 171, 223

institutional framework 2, 48, 54-5, 166, 229, 215; in Scotland 246

institutions 55, 84, 210; commercial stage 94; of economics 210, 231; of education, law and religion 246; Scottish 147, 234, 240-1

instruments 92, 204, 207; and goods 210; rate of return on 205

intellectual history $3,115,132,139,160-1$, 203, 236

interest rates 5, 48, 62-3, 93, 173; reduction of 63

international trade $3,53,57,85-6,92,171-2$, 189-90, 201, 206-8; specialisation 172, 201; theory 199, 207

invariable measure of value 164,168

invention 87, 166, 204-7, 211; engineering 209; of machines 205; new 3; promotion of 201; role of 205

investment 3, 24; capital 159; opportunities exhausted 167

invisible hand 48, 102, 150-1

Ireland 98, 143, 169, 172

Jacobites 97, 99; Culloden 72; Scottish Highlands 5, 48, 99; rebellion 3, 5, 71-3

judgement 135 ; capacity for $5,29-30$; standard of 126,138 ; subjective 43 jurisprudence $31-2,116,147$; theory of 108 justice 49, 56, 66; and liberty 161

\section{Keill, John 112, 118}

Keynes, John Maynard 23, 103, 223; General Theory of Employment, Interest and Money 23; innovative approach 252; Newton, The Man 103; post-Keynesian economics 210-11; pre-Keynesian theorising 11-12; Treatise on Money 23

Keynes, John Neville Scope and Method of Political Economy 219

labour 16, 30, 33, 36, 41-2, 50, 80, 84-6, 154, 168; augmentation 204; child 166, 170 ; costs of production 184; demand for 169 , 174, 181, 189; efficiency 222; fixed capital/labour ratios 167; fruits of 34,65 ; joint 32; low-wage 11; marginal product of 185; markets 170; other men's 41; price of $180,182-3$; to produce goods 37 ; productive $51,166,190,205$; quantity of
41, 169 ; rates of 38 ; separate 33 ; as source of happiness 51 ; supply functions 169 ; theory of value 43, 167; units 41, 204; unproductive $166,169,180,186,190$; value of 39; and the war 223

labourers 58, 186-8, 191; gains distributed to 184; numbers 180 ; numbers increase 182-3 laissez-faire 166, 175, 179, 200; in banking 171 land shortage 175, 183

landlords 157, 181, 186; absentee 172; income of 191; prodigal 63

Lauderdale, Earl of: An Inquiry into the Nature and Origin of Public Wealth 22

Law, John 1, 4-5, 60, 249; banking proposals 9, 12; criticisms of 20; economic policies 14; Essay on a Land Bank 10, 23; exclusion of 13, 22; failures as policy maker 23; French model 23; Money and Trade 13-15, 19, 23; paper money 21; reputation 14; Royal Bank 14; System 25; theories 18

laws 22, 52, 54-5, 62, 86, 105, 149; of human nature $6,130,150,152-3,158$; of inheritance 187; of motion 130; and order 203; of society 55,57

legislator $64,205-7$; advice to 63

legislature 95-6, 200

liberty $7,53,93$; individual 5 ; spirit of 89

Locke, John 29, 49, 60, 63; theory of knowledge 148

London School of Economics 231, 234, 237, 239

long-term trends 49,88 peace and stability 57 luxury $66,84,86-8,92-3$; consumption 53 , 200, 208, 211; goods 180-2, 184, 190

machines 85, 92; harmful effects of 167 MacLaurin, Colin 75, 113-14, 118, 130; An Account of Sir Isaac Newton's Discoveries 119 macroeconomic focus 83, 157, 223

Malthus, Thomas Robert 156, 159, 163-4, 168, 174, 180, 182, 184-5, 188, 190-3; An Essay on the Principle of Population 156, 174, 183; mechanism 167, 169; on population 184,203 ; theory of gluts 157,160 ; theory of overproduction 6

Manchester School of Economics 231, 234

manufacture 42, 58, 66, 81, 87, 141; domestic 206; over-development 166; overproduction 157-9, 192

manufacturers 54, 61, 82-4, 154; profit 81 marginal analysis 220-1

market 49-50, 55-6, 96, 172; allocation 81-2; British 175; competitive economics 116; coordination 247; efficacy of 179; failed 89, 91-2; forces 170; free 188; global 59; price mechanism 110-11, 151; process 111; system 247; wider 85

Marshall, Alfred 218, 220-1, 228; Economics of Industry 216; Elements of Economics of Industry 217; Principles of Economics 217-18, 220 
Marx, Karl 90, 163, 180, 186, 193, 247; Capital 192

mathematical systems $107,128-9$; economics 215, 217; regularity 105, 118

mathematics 114; and experiment 127; in moral philosophy 111

McCulloch, John Ramsay 1, 6, 189-90, 192, 194, 214, 248; biographical notes 163-5; Commercial Dictionary 164-5; economic writings 165; Geographical Dictionary 165; monetary theory 170; published output 164; reputation 164

mechanical philosophy 53, 111-13

medicine 199, 209

Melon, Jean-François 14; Essai politique sur le commerce 15

merchants 54, 61, 66, 80, 83, 88, 154, 199; Company of Edinburgh 232; of Glasgow 187; prosperous 162; theory of trade 23,96 , $157,207,216,247$

metallic money 16-17, 20, 24, 37-9;

banishment of 18 ; distribution of 170 ; fluctuation 171

methodological approach 106, 153; differences 152; order 127; thought 252

middling sorts of people 54-5, 63-4, 66

military $62,156,186$; protection of the nation 50,56

Mill test 207

Mill, James 1, 4, 6, 165, 193-4, 199, 246, 248-49; Analysis of the Human Mind 148; biographical notes 146; economic theory 156; Elements of Political Economy 147, 149-51, 154-7, 222, 224; Essay on Government 149; methodology 149-53, 155

Mill, John Stuart 7, 147, 150, 180, 192-3, 198, 203, 207, 211, 216; On Liberty 160; System of Logic 150

Mirabeau, V. R. 72, 80; Friend of Man 87

Mississippi System 12-14, 18-19, 21, 23, 59

modern economic theory 42, 84, 94, 235, 248

monarchy 56-7, 67, 96; position of the Crown 77-8; power 93; universal 92

monetary policies $10-11,24-5,60-3,93$, 248-9; expansionary 18; restrictive 87; revolution 25

money 15-17, 19, 37-8, 48-50, 55-6, 63, 77, $80,159,170$; in circulation $10,12,21,24$, $93,154,170$; and credit 64 ; demand 11 ; flux of 84; hoarding 158-9; inflow 59, 61; influence of 24; manipulation of supply 93 ; mechanism 63; mixed currency 171 ; nonmetallist theory 60; non-neutrality theory of 4; outflow 61; properties of 60; quantity theory 10, 154, 249; Scottish system 23; specieless system 25; taxation and public finance 218; theories of 248; value debasement 38, 155-6

money stock 5, 59, 62, 156; dead 20;

European 11; expansion of 4, 15-18, 61,
154,156 ; increase in 60,62 ; insufficient 12

Montesquieu, Baron de 52, 65-6, 72, 86, 98; Persian Letters 14

moral and religious education 7, 183, 187, 189, 248

moral philosophy 106, 133, 135, 140, 142-3, 148, 194, 215, 217-19, 223-4; disadvantage in 135

morals 58, 66, 94; and discrimination 135; self-restraint 29, 79, 174, 188

multiplier process 61-2, 67, 141

national debt 4, 12, 18, 60, 67, 163; essay on the 164

National Resources 180, 182-4, 190, 192

natural philosophy 75, 105-6, 112-14, 127-8, 133

neoclassical economics 102, 111, 220, 223

Netherlands, the 71, 207

newspapers 222

Newton, Sir Isaac 75, 102-4, 106-7, 109-19, 124, 127, 132, 135, 140, 142-3, 214; aesthetic heritage 136; biographies of 103, 116, 118; French reception of 113; General Scholium 104, 106, 117; interpretation of 113; law of gravity 113; Method of Fluxions 118; optical work 113; Opticks 104-6, 128-9, 132, 135, 140; Philosophiae Naturalis

Principia Mathematica (Principia) 104-6, 111, 113, 116-17, 128, 130, 135, 143; physics 102, 108, 112-14, 118; style 111; planetary movement 109, 128; theory of light 105; third law 110; unpublished papers 106; works 131

Newtonianism 104, 111-14, 119; moral 124

Newton's experimental philosophy 106, 114, 124-5, 128-35, 140-3; interpretation of 140

Newton's methodology 103, 108-9, 111, 115, 119, 247, 251; experimental 6, 74, 107, 124, 138,140

Nicholson, J. Shield 2, 4, 7, 216, 219-21, 223-4, 231-2, 234, 237; War Finance 223

nineteenth century 1-2, 6-7; economist 193; Scotland 209, 223

North America 7, 98; colonies 5, 30; institutionalism 199, 2489; mainstream approach 228; society 248; United States 239

observations 75, 124, 129, 131, 134-5, 142; with common principles 139; of human life 134

open-ended theories $6,105,111,210$

Oxford University 234; approach in economics 241; influential Scots 233; tradition of political economy 224

Palgrave's Dictionary of Political Economy 31 
paper credit 16-18, 21, 25, 60; discipline over 62

paper money 5, 10, 13, 16-20, 23-4, 154, 223; inflation 171; privately issued 60; state issued 63

Paris, University of 113, 210

Parliament 193, 224; Act of Union 13; Scottish 9, 12-13; union 214

patterns of association 135-6; resemblances 133-4

Pemberton, Henry 113, 130, 132

Petty, William: Political Arithmetick 111

philosophical system 3, 6, 125-7, 214

philosophy 109, 141, 223-4

police $52,87,90$

political economists 60, 192, 202, 209; in England 190; leading 219

political economy 7, 9, 22, 46-7, 76, 78, 86, $89,102,107,111,116,147,161,178-9$, 186-7, 189, 191, 205, 209-10, 213, 216-19, 222-3, 232-3, 247; classical 180, 194; Club 148; English classical 214; evolution of 215; introduction to 230 ; lectures in 183 ; principles of 95; Scottish see Scottish political economy; social and moral purpose of 241; study of 97, 224; teaching of 194; theorems of 193; thought-based 239

politics 47, 56-7, 96; changes 47, 54, 64, 77, 84, 86; devolution 241; and economics 125 ; factions 57; improvements 48, 55; pressures 94, 96 ; reform 160

Poor Laws 187-8; Reform Acts 148, 174; reformers of the 248; Royal Commission 218, 221-2, 242

poor relief 174, 188; burden of 188

population 5, 78, 79, 180-4, 189, 205;

agricultural 186; concentration of 175 ; depopulation 73; disposable 186, 190; figures 111; growth 79, 83; mechanism 167, 174; movements 3; reduced 188; restricted 174; theory 78-9; working 169

potential for economic growth 79,85 ; demand-led 84

poverty 186-8; pauperism 174, 218; relief 249; urban 178-9

power 78; distribution 78; of purchasing 39; of the sovereign 95

prices $35,77,81-3,155$; of commodities 36 , $83,110,154$; of credit 62 ; domestic levels 88 ; equilibrium 116; factor 207 ;

fluctuations 11, 60-1, 175; of food 169; importation 91; increase 16; mechanism 10, 110, 116, 150; natural 110; relative 156

principles 142; from experience 3 ; of population 186 ; of self-interest 81 ; statement of 75

production 11, 157-8, 186, 204, 206-7, 217; agents of 155; cessation of 67 ; diminution in 157; domestic 59, 190; of food 79; implicit functions 191; increase in 154-6; laws of 149, 217; margin of 168; new methods of 90,205 ; output 11, 168; prices 61; specialised 247

productivity 53, 63, 159, 166-9; increase 61; low 59

profits 42, 63, 83, 87, 110, 166, 169, 181, 211; upon alienation 81 ; in the economy 167 ; fall 63; going rate of 168; marginal rate of 171 ; rise of 87

property $33,50,56-7,66-7$; demand of owners 181; for disposal 158; distribution of 86 ; mobile 21 ; protected 188; respecting 49 ; rules 49; security of 166,170 ; tax 173 property rights 33,55 ; private 186,188 proprietors $182,188,190$

prosperity $46,49,53,55,61-2,88$; material 48 psychological approach 133-4, 137, 142, 148, 150

psychological laws 149-50, 153

public finance $6,172,174,216,248$; expenditure 165, 174; theory of 249

public securities 17, 62; state issue 63

Pufendorf, Samuel 5, 31-2, 34-6, 42-3, 247; De Jure 38; De Officio 37

radical 147; reformers 187

Rae, John 1, 7, 118, 249; biographical notes 198-9; Life of Adam Smith 118; New Principles 198, 200, 203, 205-6, 208-9, 211; theory of capital 204; treatment of savings 211

reason and judgement, role of 123, 126, 142 recession 157; 1818 156; analysis 157 reductionist theories 191; programme 150 , 153

Reid, Thomas 123, 125-6, 132, 143, 150; criticism of Hume 126

religion 52, 104, 131, 146, 166, 187-8, 194; Presbyterian views 208; social benefits of 188; work ethic 51, 199

rent $42,110,168,181,183,188$; on market position 169; remittances 172; theory of 182 resources: allocation of 172; enlargement of 183; natural 166; under-utilisation of 10 revenue 173-4; public 62; sources 42,172 revolution 53, 78, 90, 97, 99; ideals 199; industrial 166; scientific 124

rhetoric 110, 139; ordinary discourse 76, 138, 140 ; role in economics 251

Ricardo Memorial Lectures in London 164

Ricardo, David 7, 43, 149, 163-5, 167-8, $171-4,180,182,188,191,193,207$, 216-17, 248-49; canonical analysis 185; deductive emphasis 6, 214; Principles of Political Economy and Taxation 147

Royal Society 127

savings 24, 159-60, 169, 173, 203-4, 211; and investment 205; from revenue 201

Say, Jean Baptiste 86, 157; law of markets 157; Treatise on Political Economy 157 
Schumpeter, Joseph 92, 199, 210-11; History of Economic Analysis 102; Theory of Economic Development 211

science 59, 72, 139, 223; and aesthetics 137; and human nature $3,107,133$; innovations 54; of politics 78; progress of 201, 206

scientific enquiry 127; analytical method 214; open-ended 109-10; principles of 2501

scientific progress 104-6, 116, 140; conditional nature of 109; psychological stages 109; research 118

Scott, William Robert 2, 8, 234-5; Francis Hutcheson: His Life, Teaching and Position in the History of Philosophy 21

Scottish Economic Society (SES) 8, 214, 237-9, 241

Scottish economics 1, 3, 6, 11, 163, 193, 198, 220-1, 228, 248-49; applied nature 7; and social policy concerns 238, 241

Scottish Enlightenment 2, 9, 21-2, 103, 107, 112-15, 123-5, 132, 150, 161, 194, 198, 213, 215, 221, 246-8, 250-1; thinkers 249; thought 4; writers 13

Scottish Journal of Political Economy 8, 238-9, 241

Scottish philosophy 2-3, 6, 124-6

Scottish political economy 1-2, 23, 190, 193, 198-9, 209-11, 215, 220-4, 228-30, 233, 235, 238-40, 242, 246, 2490; characteristics of 214-15; historical school 77; history of 7

Scottish Society of Economists 237

Scottish system of education 7, 221; parochial schools 175

Scottish tradition 4, 7, 229-33, 236-7, 241, 245-6, 249-51; in economic thought 214; in enlightened thought 125, 160-1; of enquiry 175; in mathematics $114,129,160$; in political economy 213, 220, 235-6, 238, 240

Scottish universities 3, 8, 112, 194, 213, 215, 223, 228, 231, 239-40, 249; academic economists 234, 241; curriculum 224, 241; new 239; new discipline 224; political economy 231; professors of political economy 234-5; report on 224; system 229, 241

Senior, Nassau 198, 218, 248; New Poor Law 1834174

seventeenth century 1, 50, 124, 127, 143

shares 12-13, 19

shipping 57, 166, 236

short-term effects $63,91,190$

silver and gold 38 ; imports 11 ; money 60

simplicity 131, 140-1; ideal of 137

Simpson, David 239, 241

Smart, William 2, 7, 217, 219-24, 231, 235, 241-2; Distribution of Income 222; Economic Annals of the Nineteenth Century 222

Smith, Adam 1, 4-8, 9-10, 14, 18-25, 27-8, 30-1, 39, 42-3, 51, 63, 72, 80, 82-4, 86, 90, $96-8,149-50,159-60,165-7,178,180,182$,
186, 193-4, 198, 200, 204, 209-11, 213-19, 221-3, 234-6, 238-9, 246-7, 250-1;

authority 91 ; biographical notes 107-8; Chair 232; Commissioner of Customs 107-8; conceptual system 96; course in economics 31, 43; Dublin edition of $W N$ 98; Essays on Philosophical Subjects 108-9, 117; History of Astronomy 103, 108-9, 118, 124, 134; Lectures on Jurisprudence 18-19, 31, 43,83 ; Lectures on Rhetoric and Belles Lettres 139; methodology 106, 125, 134, 138, 141-2; moral philosophy 132;

Newtonianism 111, 115; notion of common sense 125; Of the Imitative Arts 139; political economy 111, 136; system 138, 249; Theory of Moral Sentiments 42, 84, 102, 107, 134; Wealth of Nations 18-19, 22-3, 31, 39, 42-3, 86, 90, 95-7, 102-3, 107, 110-12, 116, 135-6, 141, 149-50, 159, 165-8, 178, 198, 200-4, 209, 214-19, 246, 250

smuggling and corruption 172-3

Social and Economic Research Department (SERD) 235-6, 242

social and economic theory 149, 151

social institutions 150-1, 161

social problems and policies 211, 223, 233,

238, 248, 251; in Scotland 236; unrest 50, 188

social reform 7, 48, 147-8, 160, 230

social sciences $76,108,151,215,238$;

experimental method in 134, 140

social stability 51, 170, 175; precondition of 30

society 47-9, 54-5, 150, 153; conventions 5, $56,65,210$; members of $32-3$; stability of 170,203 ; stages theory $77-8$; structure 28 , 30,63

South Sea Company 13, 21, 23; bubble 59; Panama 58

specie 18-20, 59-60, 155; payments 171

specie flows 171-2; international 64; mechanism 59-60, 62, 248; price-specie-

flow mechanism 249

Speenhamland system 174

spillover effects 202

St Andrews University 112, 178, 182, 215-16, 232; calendar 218; Professor of Moral Philosophy 182

standard 169; of enjoyment 191; of living 84, 175,223 ; of taste 137 ; of value 38

state $5,59,61-4,88,95$; intervention 7,89 , 201, 206-7; involvement 60 ; revenue of the 77

statesman $89,91-4,96$; role of the $85,88,95$

Steuart, Sir James 1, 5-6, 9, 21-3, 73, 249; biographical notes 71-3; Considerations of the Interest of the County of Lanark in Scotland 91; Principles of Political Economy 22-3, 72-3, 78, 89, 90-1, 95-8, 156, 164-5, 192-3, 208, 216, 220, 223, 231, 234; The Works 72, 95 
Steuart-Denham, Sir James see Steuart, Sir James

Stirling University 239

Stirling, Patrick J. 192

stock exchange 12, 17-18; Change Alley 17; losses 170; Royal Exchange 65

stock of goods, value of whole 40-1

Strathclyde University 239

subsistence 77, 80; farming 90; materials 83; produced 181; psychological 169, 173-4 successive approximations 103, 117-18

supply 84 ; and demand 10, 81-3, 86, 158; foreign 175 ; limited 82 ; price $35-6,81,169$; secured 91

Swift, Jonathan 139; language 115, 125

synthesis 75,106

taste $84,86,183,188-9$; formulation of 208 ; refinement of 54-5, 66

taxation 187, 190, 217; burden of 173,191 ; commodity 172-3; effects of 183; financed by 192; increase in 173; manipulation of 93; work on 165

taxes 55, 63, 77, 83, 172-3; arbitrary 66; direct 172-3; imposition of 93 ; indirect 173 ; on luxury consumption 66

technology 204-6; imported 200, 207; progress 191

theoretical systems 76, 139, 238; analysis 127, 156, 160; appraisal 3, 210; arrangements 135-6; influence from Scottish thinkers 251

theory, limitation of $3,214,240$

time 152-6, 159-60; given period of 157 ; interval 204; role in economic processes 154 trade $4,12,15,19,53,59,63,80,86-7,95$, $171,217,223$; advantages 82 ; balance 47 , 112 ; barriers to 7 ; between nations 67,85 , 88; colonial 174; foreign 58, 187, 191, 208; gains from 207; import duties 172-3, 206; inland 87; money and 6, 157-8, 235; open 92; protection 222; surplus 61 ; unions 170 ; world 57

tradition 2-4, 209, 240; of economic thought 229; of historical economics 231; national 224, 233

transport 86, 91, 217; costs 172

Turnbull, George 106; The Principles of Moral Philosophy 107

undeveloped nations 86,91

unemployment 4, 10-11, 151, 156, 217-18; massacre of Peterloo 156

unity 131-2, 141, 213; in multiplicity 137-8, 142

universities 22, 124; calendars 7, 216-17;
Chairs 7, 107, 165, 186, 216-17, 232-3, 235, 242; Departments 215, 221, 223, 239; discipline 7, 213

university curriculum 3, 224, 233; breadth 223; of economic studies 231, 234; new courses added 216-17; political economy 215; recommended texts 219, 223, 233; in Scotland 215; social economics 218, 232-3; undergraduate 228-9, 233;

University of London 165, 186, 237

university political economy courses 216-17, 219; degree 217, 239; honours classes 230, 232, 237; ordinary course 218, 233

utilitarian economics 148, 248; English 147, 160-1

utility 39, 40-1, 217; expected 35; of goods to be acquired 34, 40; issues of 43; public 166

value $6,34-5,37-40,80-2$; determinants of 43; of fixed changes 171; of goods 34-6, 39, 41 ; increase in 168; invariable measure of 249; paradox of 10, 43; of receipts 42; relative 168; scarcity $34-5,40-1$; theory of $7,34,168-9,221-2,247$; in use 40

wage $42,51-2,110,168-9,182$; changes in 183; equilibrium 180; high 59, 170, 184; and housing 222; increase $61,167,188$; non-agricultural goods 167; and prices 11; real 181, 189; reduction 11; structure 236; subsistence 174, 180, 185

wage earners: hardship to 175 ; welfare of 170 Walras, Léon 102-3, 111-12, 116 war 52-3, 151, 182, 223; American 72; economic consequences of 73; finance 173 , 190, 192; First World War 228-9, 231, 233; French 182; Napoleonic 156, 223; service 236

wealth $18,19,51,53,78$; accumulated 62 ; available 62; distribution of 85,217 ; increase of 201; of inhabitants 93; of the nation 201, 205, 222; new sources of 77; responsibilities of 223

welfare 39, 42, 88, 190; economies 116 ; measure of 39,42 ; and social problems 90 , 230, 236; state 221

Westminster Review 148

von Wieser, F. 234; Natural Value 221

Whig position 30,56

work 51-2, 184; and demand 91; pleasure from 51, 184; workhouse 174

work force 180-1, 183, 189; reduced 188 workers 51, 61, 65; exploitation 186, 223; hardship for 67; productive 52; skilled 33, 201; slaves 84 working world, history of the 222 
